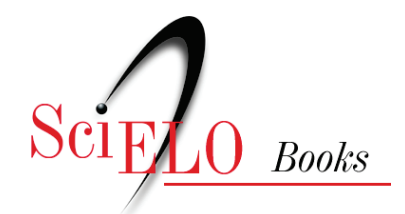

\title{
Religiosidade na Revolução Francesa
}

\author{
Ignasi Terradas Saborit
}

\section{SciELO Books / SciELO Livros / SciELO Libros}

SABORIT, IT. Religiosidade na Revolução Francesa [online]. Rio de Janeiro: Centro Edelstein de Pesquisas Sociais, 2009. A sombra de Jean-Jacques. 314 p. ISBN: 978-85-99662-98-4. Available from SciELO Books $<\underline{\text { http://books.scielo.org }>\text {. }}$

\section{@()(@)}

All the contents of this chapter, except where otherwise noted, is licensed under a Creative Commons Attribution-Non Commercial-ShareAlike 3.0 Unported.

Todo o conteúdo deste capítulo, exceto quando houver ressalva, é publicado sob a licença Creative Commons Atribuição Uso Não Comercial - Partilha nos Mesmos Termos 3.0 Não adaptada.

Todo el contenido de este capítulo, excepto donde se indique lo contrario, está bajo licencia de la licencia Creative Commons Reconocimento-NoComercial-CompartirIgual 3.0 Unported. 


\section{Ignasi Terradas Saborit}

Esta publicação é parte da Biblioteca Virtual de Ciências Humanas do Centro Edelstein de Pesquisas Sociais - www.bvce.org

Copyright (c) 2009, Ignasi Terradas Saborit.

Copyright (c) 2009 desta edição on-line: Centro Edelstein de Pesquisas Sociais

Ano da última edição: 1989.

\section{Religiosidade na Revolução Francesa}

Nenhuma parte desta publicação pode ser reproduzida ou transmitida por qualquer meio de comunicação para uso comercial sem a permissão escrita dos proprietários dos direitos autorais. A publicação ou partes dela podem ser reproduzidas para propósito não-comercial na medida em que a origem da publicação, assim como seus autores, seja reconhecida.

ISBN 978-85-99662-98-4

Centro Edelstein de Pesquisas Sociais

www.centroedelstein.org.br

Rua Visconde de Pirajá, 330/1205

Ipanema - Rio de Janeiro - RJ

CEP: 22410-000. Brasil

Rio de Janeiro

Contato: bvce@centroedelstein.org.br 


\section{SUMÁRIO}

\section{Prefácio}

\section{Introdução}

A liberdade absorvida pelo capitalismo e as tentativas de um novo condicionamento moral da sociedade.

O discurso do desprestígio da Revolução Francesa .................................... 7

A historiografia essencial

.7

\section{As Exigências Revolucionárias da Religião}

A celebração católica da Revolução. .15 Jansenismo, Galicanismo, Republicanismo e Revolução. A Constituição

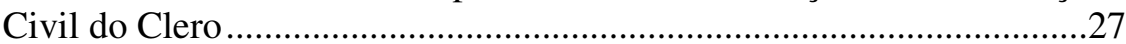
Grégoire: a integridade evangélica e jacobina .......................................31 A justiça evangélica e o sentimento religioso na Revolução. Fauchet....42 Nota sobre a franco-maçonaria...........................................................69

Jacques Roux: a crítica da liberdade sob o capitalismo ...........................73

Félicité Lamennais: a persistência do contrato evangélico .....................78

\section{Progressos e Limites do Ateísmo}

Volney: o ateísmo moderado . .95

Cabanis e Marat: a alma explicada psicologicamente ...........................100

Fatalidade e repouso. D'Holbach e sua influência ...................................105

O culto da razão e da liberdade ...........................................................115

A teofilantropia. A força do deísmo comparada à do ateísmo ante o

catolicismo

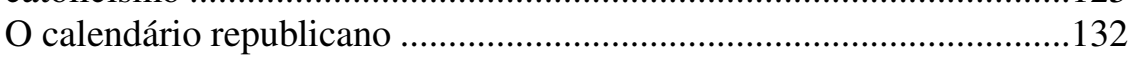

A santa guilhotina

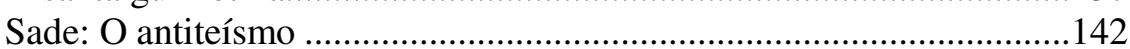

A Religiosidade da Revolução

O Panteão e as panteonizações

David: símbolo e dramatização ........................................................ 174

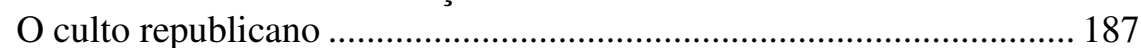

Nota sobre a Revolução Americana de Independência ....................... 209

Deísmo Patriótico e Deísmo Político. 212

A força da linguagem e a religião................................................... 212

Robespierre: resistência republicana e condicionamento moral do capitalismo

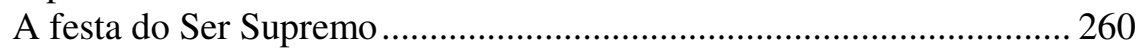

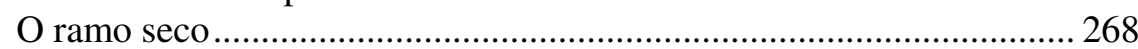

Utopia e Reação Conservadoras 270

De Maistre: providencialismo e razão cínica ...................................... 270

De Bonald: utopias do conservadorismo ......................................... 276

\section{A Sombra de Jean-Jacques}

Restif de la Bretonne, Mercier e Chateaubriand: mística e miséria...... 284 A ilusão de Saint-Pierre ................................................................... 297

A apoteose de Rousseau .................................................................... 299

A ilha dos álamos trazidos da Itália................................................... 308 
A motivação original deste livro derivou de uma conversa com Bernardo Sorj sobre a importância da religiosidade na história dos conflitos e das revoluções sociais. Sorj ressaltou como "a revolução enfrenta o pensamento religioso no seu próprio terreno, absorvendo uma parte de suas preocupações sobre os fundamentos da ordem social, da ética, do sentido da vida e do destino humano", sem esquecer "as modificações do próprio pensamento religioso sob o impacto da ideia revolucionária". Sorj sintetizou assim a interação entre a Religião e a Revolução:

A revolução reintegra em suas próprias estruturas cognitivas e práticas elementos centrais da instituição e do pensamento religiosos, e o pensamento religioso absorve a revolução em suas formas de atuação e teologia.

A elaboração do presente trabalho foi possível graças a um convite de Maurice Godelier em nome da École des Hautes Études en Sciences Sociales e da Maison des Sciences de l'Homme. Os textos que selecionamos procedem de transcrições e de algumas fotocópias realizadas na Bibliothèque Historique de la Ville de Paris, na Bibliothèque SainteGenevieve e na Bibliothèque de la Maison des Sciences de l'Homme. O critério utilizado para a tradução dos textos foi desenvolver descritivamente (explicitar) o significado das palavras de difícil tradução na linguagem atual. Para não desviar excessivamente a atenção do leitor, não comentaremos sistematicamente a tradução ao longo do livro. Para dirimir algumas dúvidas, consultamos o Dicionário Francês-Espanhol / EspanholFrancês de Núñez y Taboada (Paris, 1812,2v.) mas, de maneira geral, só lançamos mão de equivalências extraídas de dicionários lexicográficos unilíngues.

\section{A liberdade absorvida pelo capitalismo e as tentativas de um novo condicionamento moral da sociedade}

Este livro aborda o estudo da relação Religião-Revolução num caso paradigmático: a Revolução Francesa. Tentamos compreender as colocações e a mentalidade da época sem descuidar de uma teoria histórica do fenômeno teoria que nos parece próxima da tradição marxista. Ao mesmo tempo, nos empenhamos em proporcionar uma reflexão útil para a consciência que se tem dos fenômenos religiosos em países como o Brasil, onde a Religião é protagonista de destaque nas mudanças e conflitos sociais.

Dito isto, passamos a expor os princípios teóricos desta compilação e comentário de textos. $\mathrm{O}$ aspecto da Revolução Francesa que queremos ressaltar é o seu combate contra a elevação da economia à condição de instituição preponderante e condicionadora de todas as demais, fenômeno cujo apogeu ocorre a partir da Revolução Industrial, e outras mudanças ocorridas entre os séculos XVIII e XIX. O debate político e teológico durante a Revolução Francesa, bem como as formas de religiosidade republicana e patriótica, atestam um esforço para atacar ou desmistificar o "grande sistema" que se está impondo, transcendendo vontades e consciências que incessantemente se alarmam ou se rejubilam com tal processo. Se a escassez, o "problema financeiro" denunciado desde a época de Necker, a agiotagem, o "negocismo" e a "anarquia" são qualificados como resquícios do Antigo Regime e causas da Revolução, bem como da situação pós-revolucionária, é porque apesar de tudo o capitalismo não se detém em seu avanço institucional. Por esse motivo, a Revolução Francesa enquanto revolução contra o Antigo Regime gera uma liberdade que, por ser rapidamente absorvida pela institucionalização capitalista, logo necessita de outra revolução dentro da "revolução burguesa", revolução que dificilmente irromperá por si mesma e terá um certo cristianismo evangélico como principal aliado. Esse fenômeno merecerá nossa atenção, bem como o da religiosidade ou celebração cerimonial e discurso sacralizador dos princípios republicanos e humanistas da Revolução. 
A força que parece ser destilada pelo fervor cheio de religiosidade, de cerimonialidade, de desejo de imortalizar os gestos, que a Revolução Francesa nos apresenta constantemente, não se dissolve em pura quimera ou ridícula caricatura como pretenderam alguns autores. A reflexão de Quinet sobre os extremos reais da Revolução nos leva a considerar com seriedade o que, em outro contexto (a partir de onde se decidem muitas interpretações), seria algo superficial ou puramente propagandístico:

Entre tantas coisas extraordinárias, a mais assombrosa é sem dúvida ver um povo assediado que, depois de ter perdido a metade de seu território, conservando por milagre a outra metade e não se permitindo outra retirada além da morte, gera mil projetos para a humanidade, delibera sobre teorias enciclopédicas de educação, administração, ciência, cria um novo sistema de pesos e medidas e um novo calendário, tudo como se a paz mais prazerosa o estivesse mantendo num agradável refúgio.

Embora, evidentemente, a situação tenha sido muito agitada, é certo que o contexto cultural da Revolução continuou desenvolvendo várias filosofias de vida e da sociedade, vários projetos científicos como os de Laplace, Legendre, Monge, Coulomb, Cuvier e os passos decisivos de Lamarck em sua teoria da evolução.

Assim era medido o progresso da razão útil que a Convenção Nacional tentava plasmar em diversos projetos durante à Revolução e suas agitações:

Em breve as artes serão levadas a novos progressos mediante a uniformidade dos pesos e medidas cujo tipo único e invariável, tomado da própria medida da terra, fará desaparecer a diversidade, a incoerência e a inexatidão até agora existentes neste setor da indústria nacional.

As artes e a história, para as quais o tempo é um elemento necessário, também solicitavam uma nova medida de duração, livre de todos os erros que a credulidade e a rotina supersticiosa transmitiram, através de séculos de ignorância, até nossos dias.

${ }^{1}$ QUINET, Edgar, Oeuvres Complètes, t. III, Le Christianisme et la Révolution Française, Paris, 1857 (primeira edição: 1845), p. 235.
É esta nova medida que a Convenção Nacional apresenta hoje ao povo francês; ela deve ter, ao mesmo tempo, as marcas das luzes da nação e o caráter de nossa revolução por sua exatidão, sua simplicidade e sua independência de toda e qualquer opinião que não seja avalizada pela razão e pela filosofia.

A crítica "como a de Quinet" que será feita a Robespierre de intrometer-se na privacidade da consciência, revela o império que o capitalismo pretende obter sobre a consciência e a vontade humanas. "Pedir o que os homens modernos não podem conceder": o "homem moderno", submetido ao realismo econômico capitalista, não quer se deixar condicionar publicamente por uma moral transcendente de suas instituições mais públicas. Porém, a existência desse condicionante durante a Revolução Francesa é o que leva Quinet a dizer que durante o Terror é mantido "o temperamento do catolicismo, e com mais idealismo que o próprio catolicismo".

A Revolução Francesa consegue um personalismo nas iniciativas e movimentos sociais que não terá continuidade nos avatares cada vez mais anônimos e maciços do capitalismo. Nunca tantos nomes estiveram associados a tantas tendências e a tantos fatos. Os principais personagens da Revolução Francesa, plenos de questões políticas, filosóficas e religiosas, testemunharam um esforço de personalização frente à mais despersonalizadora de todas as máquinas históricas, quando consegue dominar com absoluta soberania.

Mas o próprio Quinet, depois de 1830, aferirá com maior justiça o imperativo de condicionar moralmente o capitalismo gerado com a Revolução Francesa ${ }^{4}$ :

Depois dos acontecimentos de 1830, todos nós pudemos ver surgir da terra uma espécie de rio subterrâneo; algo inesperado para muitos. Do abismo onde jazia, contida, irrompia até nós uma coisa que ninguém conhecia bem, a guerra de classes, a inimizade entre burguesia e o povo.

\footnotetext{
${ }^{2}$ Le Moniteur, t. 18, $\mathrm{n}^{\circ}$ 87, de 17/XII/1793, p. 675.

${ }^{3}$ QUINET, op. cit., $13^{\mathrm{a}}$ lição.

${ }^{4}$ QUINET, op. cit., $15^{\text {a }}$ lição.
} 
No que tem de verdadeiro, o espírito da Revolução Francesa é o de identificar-se ao princípio do Cristianismo. Em meio a todas as paixões vertiginosas, essa ideia reaparece de vez em quando, de Mirabeau a Danton; a arca da aliança que brilha sob a chuva de sangue pode ser considerada uma herança de todos os partidos.

Depois de dezoito séculos, o homem começa por fim a declarar que Deus encarnou-se no homem; essa consciência cheia de reflexão sobre a presença do Espírito Divino cria um novo Código de direitos e deveres. A Revolução, desde sua origem, promete ser religiosa e universal, donde deriva uma consequência primordial: seu espírito rejeita tudo o que age em detrimento da dignidade interna do gênero humano.

Evitem, pois, rebaixar a importância da moral acreditando assim facilitar o advento da democracia; vocês estariam fazendo precisamente o contrário do que dizem querer conseguir. Tenho medo justificado, confesso, desses costumes banais que se erigem em teorias sublimes. Se querem superar a burguesia, não comecem pela apropriação de seus vícios particulares. Tudo estaria perdido se, por um estranho sortilégio, a miséria moral dos ricos se transformasse no objeto do desejo dos pobres.

...a chegada da democracia só pode representar um novo progresso do espírito, da civilização, da ordem universal. Ou a democracia será tudo isto ou nunca será nada; suposição que consideramos ímpia.

O que é preciso para apressar o encontro com o futuro? Que uma contradição patente entre a dignidade interna de um povo e suas condições reais chegue a eclodir, que esse conflito aumente sempre até que, por força das circunstâncias, não possa mais se manter como está, de tal forma que o espírito consiga emancipar o corpo; é assim que se cumprem todas as libertações duradouras que o mundo conhece.

Assim se exprime Edgar Quinet em sua lição sobre a Revolução Francesa publicada pela primeira vez em 1845. Não se trata apenas de fundamentar a moralidade profunda diante da qual a Revolução assume sua verdadeira legitimidade, e por isso deve contar com a iniciativa religiosa; mas também, que este compromisso moral da Revolução se entrelaça com um processo histórico de libertação da consciência em geral cujo expoente máximo caberá à tradição marxista.
Quinet atribui esse poder revolucionário à Revolução Francesa e a sua continuidade à aliança com a "religião mais antiga":

Coisa nova, por si grande, presságio do futuro! Há homens que acreditam já estar vivendo seu ideal. $\mathrm{O}$ que antes era considerado um engodo ou uma utopia, agora é chamado de teoria.

... a Revolução Francesa devolveu à terra a fé no impossível. ${ }^{5}$

O destino quer que a França contenha todo o conjunto formado pela Revolução mais nova e a Igreja mais antiga. O prodígio é que o futuro nasce dessa própria contradição. Luís XVI tentou superar a dificuldade com o veto, o Comitê de Salvação Pública, com o culto ao Ser Supremo; Napoleão, com a sagração; Carlos X, com as ordenanças; todos esses governos foram arrastados por essa questão que ainda não está resolvida. Como não se dar conta de que o Catolicismo está cumprindo entre nós, há meio século, uma missão extraordinária?

Pareceu-nos oportuno começar o presente livro com estas citações de Quinet para situar-nos melhor no que devemos considerar outra época, apesar do próprio Quinet pertencer a uma geração bastante distante do tempo da Revolução. Queremos dizer que precisamente na atualidade, quando ressurgem opiniões que ridicularizam ou desqualificam os esforços revolucionários da humanidade, a disposição de compreender outra época deve partir pelo menos da reflexão sobre o que tal época mais valorizava, independente do valor que hoje em dia lhe possa ser atribuído. Quinet é dos poucos autores que ainda simpatizam com os valores da Revolução, apesar de sua interpretação peculiar. Para entender a força do diálogo entre a Religião e a Revolução, é preciso compreender pelo menos a lição histórica de uma sociedade com prioridades sociais e culturais diferentes das atuais. O excessivo atualismo na história, sobretudo na história política e ideológica, prejudica obviamente esse exercício de compreensão.

\footnotetext{
${ }^{5}$ Idem.

${ }^{6}$ Idem; grifo nosso.
} 


\section{O discurso do desprestígio da Revolução Francesa}

As versões de historiadores como Tulard, Gaxote e outros ${ }^{1}-$ que praticam o reducionismo psicologista, a caricatura reacionária e o uso de clichês fictícios, amparados pela popularidade do desprestígio da revolução, complementam a interpretação de outros historiadores como Furet, Ozouf, o próprio Agulhon e vários discípulos dos mesmos - suscitaram uma evocação tardia da sociologia das elites e da psicologia de massas, como se o pensamento europeu entre as duas guerras mundiais as tivesse esquecido completamente. Diante desse equilíbrio entre a reação mais ou menos gasta e anedótica e o ideologismo tardio do liberalismo pré-reformista, a linha de análise estabelecida entre Soboul e Vovelle destaca-se por sua ponderação e pelo senso do contexto analisado.

A interpretação capitaneada por Furet parece pender para a seguinte versão ou avaliação da Revolução Francesa: sua realização mais notável seria algo assim como o preâmbulo ou como as bases da cultura liberal, o que tem sentido no contexto do individualismo liberal e do estado de direito, entendido este também conforme o contrato liberal. Todas as demais tendências da Revolução ou são submetidas a esse mero refinamento ideológico do liberalismo, ou são descartadas. Diversos atualismos acompanham essa interpretação: os clubes, as representações das seções, dos departamentos, as comissões, toda a organização revolucionária é considerada segundo os conceitos do positivismo político liberal tais como "grupos de pressão", "elites culturais ou intelectuais", "influência política", etc. Assim, a originalidade da política revolucionária é avaliada pelo que sugere em termos de germe ou aborto do parlamentarismo liberal. Nessa perspectiva, o centralismo político desenvolvido pela Convenção para dirigir a Revolução é interpretado como mera construção burocrática para controlar a oposição. E se por um lado, os fatos políticos da Revolução são travestidos como pequenas conquistas do liberalismo que se aproxima ou como defeitos do despotismo, do terror e da ditadura, por outro lado, no

${ }^{1}$ Cf. Pierre GAXOTE e Jean TULARD, La Révolution Française, Paris, 1975; J. TULARO, J. - F. FAYARD e A. FIERRO, Histoire et Dictionnaire de la Révolution Française, Paris, 1987. Comparar a Albert SOBOUL, La Révolution Française, Paris, 1962, e à recente coleção de ensaios ponderados de Michel VOVELLE, La mentalité révolutionnaire, Paris, 1985. entanto, são destacadas algumas ideias, algumas atividades culturais, por serem consideradas teologicamente significativas, apesar de ser duvidosa a sua importância durante a Revolução. Assim, algumas ideias relativas à cidadania, atribuídas à difusão das obras de Rousseau durante a Revolução, acabaram sendo muito mais valorizadas do que as outras ideias de Rousseau, constantemente repetidas durante a Revolução, sobre a lei natural como principal fonte da moral, o que se opõe precisamente às convenções da cidadania em inúmeros conflitos de justiça e liberdade. ${ }^{2}$ Em outras palavras: quis-se impor a teleologia liberal de algumas ideias da Revolução a contrapelo das correntes mais vividas durante a Revolução.

Essa apresentação da Revolução Francesa se entrosa perfeitamente com a ideologia de apoio ao capitalismo atual: reforço da noção de sistema impessoal como mecanismo mais justo do que a moral; confusão mistificadora da "sociedade civil" com o individualismo burguês e da proteção centralizada com a liberdade pessoal; descondicionamento da economia de qualquer empecilho a sua realização convencional; naturalização da formação convencional de elites; crença numa mescla de darwinismo social e sociologia política à la Pareto e Michels... Algo já velho na história ideológica europeia. Pelo visto, esqueceu-se de que a justificação de um estado de coisas, embora feita na linguagem da liberdade e da propriedade, não é o mesmo que a conquista dessa liberdade e dessa propriedade que teve de ser realizada justamente contra um "estado de coisas" análogo. Quer dizer, antes de opor um Condorcet a um Robespierre, é preciso entender o que Condorcet e Robespierre tinham em comum, e que contraria precisamente a necessidade de opô-los que hoje têm alguns neoliberais.

As tentações atualistas, que distorcem o sentido dos movimentos revolucionários, são flagrantes nas novas interpretações "liberais" que desprestigiam a Revolução Francesa. Qualquer historiador precisa saber que antes de julgar ou descartar, e inclusive antes de interpretar um fato histórico, deve ao menos ter aprendido uma lição com o mesmo.

2 J. R. CENSER, "The Coming of a New Interpretation of the French Revolution?", em Journal of Social History, vol. 21, nº 2, inverno de 1987. 
Michel Pertué já disse que a versão de Furet sobre a Revolução Francesa ${ }^{3}$ era um estudo decepcionante e decepcionador:

Subentende (a revolução), não através de uma concepção histórica distinta mas por meio de uma posição tomada de antemão, que nunca é explicitada mas adornada com as virtudes agressivas da novidade: pensar a Revolução é, neste caso, simplesmente condená-la.

O desprestígio da devoção revolucionária não deriva apenas da comprovação do êxito real e da atitude popular em relação a ela; procede naturalmente da ideia de uma "população", da obsessão de associar toda iniciativa revolucionária à embriaguez grotesca e sanguinária das massas para poder concluir, como Morellet:

... os tiranos que a história já condenou e tratou com razão de animais ferozes, não podem ser comparados a esta besta mil vezes mais feroz chamada povo, monstro sem piedade cujas inúmeras cabeças a tomam ainda mais terrível, e que num determinado momento já foi encarado como um conglomerado de vis delatores, sicários devotos e verdugos infames. ${ }^{4}$

Essa visão é a contrapartida da versão popular dos aristocratas presunçosos, indiferentes às desgraças do povo, arrogantes diante da lei, desafiadores perante a justiça e cheios de glórias vãs.

Com esses dois estereótipos "dialogarão" os sans-culottes e os cidevants ${ }^{*}$, chegando ambas as imagens a dominar boa parte da própria historiografia da Revolução Francesa.

Sade põe na boca do prelado mais cruel e libertino de sua Nouvelle Justine $^{5}$ as seguintes palavras:

Não imaginem que eu entenda por povo a casta designada pela denominação de terceiro estado; não, de forma alguma: chamo de povo essa classe vil e desprezível que, atirada com grosseria sobre nosso planeta como a escória da natureza, só pode viver à força de penas e suores...

\footnotetext{
${ }^{3}$ Annales Historiques de la Révolution Française, $\mathrm{n}^{\circ} 249,1982$.

${ }^{4}$ Abade MORELLET, Mémoires, Paris, 1823, vol. II, p. 31.

Partidários dos aristocratas. (N. da T.)

${ }^{5}$ D.A.F. SADE, La Nouvelle Justine, Paris, 1978, voI. II, p. 822.
}

A corrente que desprestigia a Revolução Francesa acusa de retóricas e vulneráveis as manifestações da religiosidade revolucionária, tratando-as alternadamente de pueris e manipuladoras da situação política. A resposta a ser dada é que, sem negar, de modo algum, a intenção política ou mistificadora de mais de uma cerimônia e ideia, o contexto da Revolução Francesa também precisa de outra interpretação: a correspondente a uma mentalidade que abrange tanto o iluminismo como o Romantismo, para a qual não se questionava a necessidade de sacralizar e assim dotar de maior expressividade determinados gestos da política e das relações abertamente definidas. Estamos falando de uma época em que o testemunho notarial registrava detalhadamente muitas vivências sociais e econômicas; em que a prece acompanhava o êxito e a desgraça, tanto de caráter "público" como "privado"; em que o heroísmo e a extrema miséria guiavam as ações mais difíceis ou desesperadas e, amiúde, a morte; em que se transmitia com a palavra e o gesto tudo o que incitava à vida ou a tornava mais amena em situações críticas como a escassez, as guerras ou as festas; em que não se discorria sobre modelos uniformes de comportamento para as massas, como aconteceria no século XX; em que o cultivo da sensibilidade e dos sentimentos era considerado aliado natural do progresso das ciências e das artes quando não, como no caso dos partidários de Rousseau, do vigor da moral; uma época sem os critérios de realismo econômico e institucional ou burocrático tal como serão plenamente conhecidos no século XX; portanto, uma época em que a cerimonialização, o ritual e a sacralização das ideias não deviam ser entendidos como estando a serviço de um "realismo" ou concerto de interesses, mas antes como expressão direta de necessidades sociais (reivindicações) ou como insinuação de outros valores morais de convivência (como os evocados pelas democracias da antiguidade). 


\section{A historiografia essencia}

Apesar de tantos livros e artigos publicados sobre a questão religiosa durante a Revolução Francesa, a obra geral de Albert Soboul continua nos parecendo a mais estimulante para a reflexão sobre a relação ReligiãoRevolução. Porque foi Soboul quem, mais atento ao espírito do marxismo do que a sua letra circunstancial, estabeleceu o papel revolucionário dos que mais tarde foram chamados de "padres vermelhos", como Jacques Roux, dos católicos jacobinos, como Grégoire, e da religiosidade que Robespierre quis implantar. ${ }^{1}$ Quer dizer, apesar das colocações, aliás predominantes na obra de Soboul, que atribuem pouca influência decisiva ao mundo das ideias e das atitudes em nome de um determinado marxismo, é este mesmo historiador que, com singular inquietude, revela-nos como ninguém a importância de correntes de pensamentos que os próprios historiadores hostis ao marxismo não conseguem decifrar, apesar de sua aparente proximidade metodológica.

O enfoque que escolhemos neste estudo e apresentação de textos toma difícil a sua discussão junto com outros estudos que se restringem mais às relações sociais das ideias, como os mais recentes de Vovelle, ${ }^{2}$ avaliando as relações entre religião e revolução segundo manifestações patentes e socialmente difundidas. $\mathrm{O}$ terreno que escolhemos dificilmente poderá ser comparado a esse outro - a não ser que comparemos alguns detalhes ou discutamos o tempo todo as teorias gerais e o valor dos conceitos. A razão é simples: o que nos interessa é mais a intenção e seu contexto geral do que as realizações ou as relações mais evidentes. Nossa hipótese é seguir o caminho das exigências mútuas entre revolução e religião: a ação revolucionária da verdade religiosa e a cerimonialização ou a maior gestualidade expressiva da intenção e da ação revolucionárias. Esta interação entre intenções e sublimações normalmente se afasta da pista de fatos - em especial dos avaliados do ponto de vista quantitativo - que são

${ }^{1}$ Cf. "Sur les 'Curés Rouges' dans la Révolution Française", em Annales Historiques de la Révolution Française (AHRF), no 249, 1982. "Introduction", em Oeuvres de l'Abbé Grégoire, Nendeln, 1977. "Robespierre ou les contradictions du Jacobinisme" em AHRF, $\mathrm{n}^{\circ}$ 231,1978 .

${ }^{2}$ Ver M. VOVELLE, La mentalité révolutionnaire, Paris, 1985, e o sistemático trabalho Religion et Révolution, Paris, 1976. ao menos igualmente importantes e foram tratados pela historiografia da "descristianização" e do "culto" ou da "festa" revolucionária.

Mas a escolha de nosso tema obedeceu à seguinte reflexão e interrogação: até que ponto e por que o cristianismo experimentou fortes exigências de revolução social, e a Revolução exigiu religião em suas expressões políticas e culturais? A Revolução Francesa suscitou tal pergunta. Para respondê-la, pareceu-nos mais adequada a indagação textualcontextual do que reconstruir fatos explícitos sobre a questão, coisa muito difícil e sempre mais refutável, já que nem os inventários de práticas religiosas podem nos dizer do nível de consciência revolucionária que a elas pode estar associado, nem os de ações revolucionárias nos dirão do nível de consciência ou intenção religiosa também a elas associado.

Se o maior incentivo historiográfico de reflexão hoje nos provém de Soboul, as obras de Aulard e Mathiez foram a mesma coisa no período tão sensível e fecundo do pensamento social francês que para situá-lo podemos chamar de "dreyfusiano", em virtude do que este famoso "affaire" pressupôs em termos da apresentação política das ciências sociais que estavam sendo geradas à época.

Aulard já destacou que enquanto por um lado a descristianização parecia se desenvolver sem obstáculos, atestando uma passividade religiosa das massas muitíssimo conhecida, por outro lado o cristianismo avançava na própria Revolução e consolidava-se politicamente diante do Estado e da Sociedade por intermédio da Constituição Civil do Clero. ${ }^{3}$

Por detrás desse cristianismo revolucionário encontravam-se inicialmente o baixo clero, o catolicismo popular já envolvido com algumas questões sociais, como se evidencia nos Cahiers de doléances, e na solidariedade com o Terceiro Estado exposta de maneira contundente por Sieyes. Aulard chega a reconhecer que "sem os padres, a Revolução talvez também tivesse sido feita, porém mais tarde e de outra maneira".

Como contrapartida, "o patriotismo, a filosofia e a indiferença" desenvolveram, por sua vez, o culto à Razão, à Liberdade e ao Ser Supremo. O deísmo da tradição filosófica esteve presente na maioria desses

${ }^{3}$ AULARD, A., Le Christianisme et la Révolution Française, Paris, 1925, pp. 26, 32, 35, 38, $72,92,95,100,102,115$ 
cultos, apesar de uma certa disputa com o ateísmo e o antideísmo. O exercício da liberdade de culto ficava confuso ao enfrentar o culto católico com suas tomadas de posição nos acontecimentos da Revolução. A Igreja foi ficando cada vez mais dizimada e confusa na medida em que rejeitava $o$ curso da Revolução ou se integrava nele. Assim sucedia com os sacerdotes juramentados e com os refratários; a seguir, com os defensores radicais da justiça popular e os contrarrevolucionários, com os fiéis à Convenção jacobina ou com os brissotinos ou girondinos. O personagem mais firme e confiante em sua tarefa evangélica durante todo o período revolucionário e até em suas mudanças posteriores foi sem dúvida Grégoire, que nunca deixou de unir a fé evangélica à preocupação com a justiça e a lealdade à autoridade legítima.

$\mathrm{O}$ estudo de Mona Ozouf ${ }^{4}$ não parece superar uma contradição que chega a invalidar o possível conteúdo teórico da obra: por um lado, Ozouf enfatiza a fragilidade das festas revolucionárias, sua "falta de enraizamento"; mas, por outro lado, tenta ver nos mínimos detalhes de cada festa o plasmar dos diferentes contextos da Revolução. Quer dizer, por um lado, em consonância com as novas interpretações que desprestigiam as ações da Revolução, frisa a fugacidade da festa ou devoção revolucionária; por outro lado, no entanto, pretende encontrar nela substância e caráter distintivo suficientes para ilustrar com perfeição os contextos históricos nos quais transcorre o período revolucionário.

Em virtude desse tratamento contraditório, a relação com algumas ideias de Freud ou Durkheim não pode ser estabelecida como pretende Ozouf. Freud não discutiria tanto o aspecto transgressor da festa revolucionária (projeção tipicamente revolucionária), mas antes a importante recriação que a festa faz das impressões e reações primigênias do ser humano, algo que em mais de uma ocasião chega a superar a religião católica. E Durkheim não teria tanta obsessão pelos "meios de adesão coletiva" num sentido quase exclusivamente político e sim, como ele mesmo afirmou a respeito da Revolução Francesa, pela atribuição de religiosidade a um conceito de contrato social.

${ }^{4}$ La fête révolutionnaire, Paris, 1976.
Por outro lado, a separação entre festa vivida e festa projetada se desvanece diante da história da festa: festa recordada, festa desejada, festa julgada, festas vividas na festa e não-festas também vividas na festa. Para captar tudo isso, parece-nos mais oportuno tentar reconstruir um contexto, apreciar outra sensibilidade, dispor de uma teoria da sociedade e de sua mudança e atentar para os principais conflitos e anelos do que efetuar uma reconstrução empírica imaginária, uma análise textual detalhada e uma "modernização" caindo em inúmeros atualismos. ${ }^{5}$

Repetimos o que já havíamos antecipado: "Uma época compreende mal a outra; e uma época mesquinha interpreta mal todas as demais com sua própria sordidez". ${ }^{6}$ Parece-nos que, diante da avalanche de ensaios tendendo a "desprestigiar" a Revolução, no extremo oposto ao "realismo", devemos empreender a tarefa que mal se pode vislumbrar de, primeiro, compreender a luta de interesses e valores de outra época e, segundo, ligá-la à nossa como herdeiros e deserdados simultaneamente; respeitar outra época como um resultado original dos conflitos de interesses e da maneira de avaliar a vida e descobrir, ao mesmo tempo, a consciência que inter-relaciona todas as épocas, a consciência do trabalho incessante a favor de uma constante libertação do homem. Assim, tem muito mais sentido agora relacionar a Revolução Francesa e sua luta religiosa, moral e filosófica à tensão que o Terceiro Mundo injeta no sistema mais ocidental, tensão cheia de conteúdo também religioso, moral e filosófico. Mas relacionar a vida da Revolução Francesa ao chauvinismo político e ideológico ocidental e seu intelectualismo autista não tem sentido histórico algum. A Revolução Francesa hoje pode ser mais compreendida e pensada em muitos países da periferia do assim chamado mundo ocidental do que na própria Europa.

\footnotetext{
${ }^{5}$ Neste sentido, não consideramos demasiado relevante para o critério aqui observado discussões como as do Colóquio de Clermont-Ferrand, Les Fêtes de la Révolution, Paris, 1977. Por outro lado, foram-nos valiosas as apresentações do contexto parisiense da Revolução elaboradas pelos alunos de M. Reinhard: Paris pendant la Révolution, 2 v., Paris: Les Cours de Sorbonne.

${ }^{6}$ WITTGENSTEIN, L., Culture and Value, Oxford, 1980, p. 86 e (1950).
} 


\section{AS EXIGÊNCIAS REVOLUCIONÁRIAS DA RELIGIÃo}

\section{A celebração católica da Revolução}

Não obstante, a Revolução começara com uma procissão solene do Santíssimo Sacramento onde figurava, com um círio na mão, Robespierre. Longe de proibir a Igreja ou separar-se dela, a Assembleia Constituinte quis transformá-la em peça chave do Estado...

Ao comemorar a tomada da Bastilha, o semanário Révolutions de Paris $^{2}$ fala da cerimônia de 30 de julho nos seguintes termos:

A maioria de Jovens se reúne e contribui em cada bairro para poder dar graças a Santa Genoveva pela feliz revolução que acaba de acontecer. As jovens da rua de Sèves, as da rua de Roule, etc., foram as primeiras a manifestar-se em procissão pelas ruas de Paris. Ó bemaventurada Genoveva, quantas preces atendeste! São Luís te pedia a conquista de Jerusalém; Luís Xl o perdão de seus crimes; Carlos IX, o dia de São Bartolomeu; Luís XIV, vitórias; e nossas jovens virgens, a liberdade! Livre-nos também dos malfeitores e dos traidores!

Nas igrejas ressoavam cânticos de ação de graças pela tomada da Bastilha. Procissões de moças, quase sempre deleitáveis, bem vestidas, adornadas com modéstia, indo a Sainte-Genevieve, cruzavam com algum batalhão de jovens guerreiros que se detinha para dar-lhes passagem, enquanto numerosos espectadores, nas ruas e do alto das janelas, externavam sua alegria com vivos aplausos.

O abade Chaix resumira e exaltara assim a aliança da monarquia com a igreja na celebração da tomada da Bastilha:

O monarca, esse Príncipe sempre bom, corre para o meio de um povo que o adora e que desejaria nunca se afastar de sua ternura. Toma parte em nosso triunfo, como um pai no de seus filhos... Fomos chamados à liberdade pela voz da natureza e pela da Religião. Ambas

\footnotetext{
${ }^{1}$ Jean LEFLON, La crise révolutionnaire (Histoire de l'Eglise), Paris, 1949, p. 104.
}

${ }^{2}$ Révolutions de Paris, $\mathrm{n}^{\circ}$ 6, 16-22 de agosto de 1789. Vários, in Collection Complète des Tableaux Historiques de La Révolution Française, 3v., Paris, 1804, T.I. p. 85. nos ensinam que o poder real é um poder paterno. Nasceu do seio das famílias... ${ }^{3}$

O discurso que o abade Chaix preparara para a benção das bandeiras do distrito de São Vitor é extremamente esclarecedor da "influência da religião sobre o patriotismo e a liberdade":

Foi principalmente da escola da Religião que o homem tirou a sublime moral da fraternidade patriótica (Diliges proximum tuum sicut te ipsum $=$ Ama a teu próximo como a ti mesmo). A religião ensinou-lhe a considerar seu semelhante, sobretudo o seu concidadão, como outro eu. O amor que te dás, lhe diz a Religião, é a medida do que lhe deves..

Depois de criticar os romanos por basearem seu patriotismo apenas em virtudes humanas, coisa que lhes acarretou a corrupção e a decadência, elogia a nova França erguida sobre as virtudes cristãs e prossegue:

Jesus Cristo, senhores, sempre amou sua Pátria. Seus benefícios chegaram a todos os lugares, mas com uma espécie de preferência por seus concidadãos; a acentuada ingratidão destes últimos não freou seu amor generoso e patriótico. Para obter dele um prodígio, bastava dizer-lhe que o homem que o solicitava estava vinculado à Nação ("Ele merece que lhe faças o favor, pois ama nossa gente e ele mesmo foi quem nos edificou a sinagoga", Lucas, 7, 4-5). Quando Jesus Cristo enveredava pela escuridão do futuro, as calamidades que se abateriam sobre sua pátria faziam brotar de seus olhos muitas lágrimas (Ao ver mais de perto a cidade, Jesus chorou sobre ela dizendo: "Se ao menos tu neste dia conhecesses o que pode trazer a paz! Mas isso agora está oculto a teus olhos. Porque dias virão sobre ti, em que os inimigos te cercarão com trincheiras, te sitiarão e te apertarão por todos os lados, te arrasarão Juntamente com teus habitantes, e não deixarão de ti pedra sobre pedra, por não teres reconhecido o tempo em que Deus veio para salvar-te", Lucas, 19 41-44). Até quando Jesus Cristo é condenado injustamente por sua pátria, ele a lamenta, e ainda a ama; passa a desviar a ternura das almas sensíveis, que se dirige a ele, para destiná-la unicamente aos acontecimentos desastrosos e inevitáveis que as ameaçam ("Filhas de

${ }^{3}$ Abbé Chaix D'EST-ANGE, De l'influence de la Religion sur le patriotisme et la liberté, 1789, p.22. Discurso preparado para a bênção dos estandartes do distrito de São Victor. Impresso mas não pronunciado, porque o tecido não ficou pronto no dia da bênção geral. 
Jerusalém, não choreis por mim, chorai por vós mesmas e por vossos filhos.", Lucas, 23, 28); quando derrama seu sangue, uma consideração particular surge para com sua Nação: no grande sacrifício que expiaria todo o universo, quer (essa é uma reflexão do profundo Bossuet) que o amor à Pátria encontre um lugar nele ("Caifás [...] sendo o Sumo Sacerdote daquele ano, profetizou que Jesus iria morrer pelo povo, e não somente pelo povo mas para reunir numa unidade os filhos de Deus dispersos.”, João, 11,51-52).

A tomada da Bastilha é o sinal providencial dessa regeneração da Igreja e da Nação:

No âmbito desta vasta capital do Império, no fundo de um jardim de fazer às margens do Sena, tinha-se há não muito tempo uma visão lamentável: um antigo Castelo, morada do horror e da destruição, no qual o despotismo, por um abuso sacrílego do nome do Soberano, devorava em segredo vítimas humanas. Sobre essas torres ameaçadoras, de onde os tiranos haviam ditado até então suas ordens absolutas, cem bocas de fogo preparadas para o massacre de cidadãos pareciam não lhes deixar outra alternativa além de morte ou escravidão. O céu Já fora golpeado pelos canhonaços terríveis e redobrados que o bronze assassino lancava contra o povo. Os Ministros da paz acorrem vindos do palácio da Comuna; a única resposta a suas propostas pacíficas é o fogo da guerra. O amor à liberdade reanima o patriotismo. A fortaleza é logo sitiada. $\mathrm{O}$ valor invencível da Guarda Francesa, a coragem intrépida dos Cidadãos, novos soldados da Pátria, operam o prodígio. Por duas vezes nossos inimigos arvoram o sinal da paz; e por duas vezes os confiantes Cidadãos experimentam a mais covarde das traições. Essa negra perfídia completa seus crimes. O braço de um Deus vingador se abate sobre eles: e um instante, um único instante, realiza a revolução assombrosa que nos transforma em alvo da admiração de toda a Europa. As enormes correntes se rompem; as pontes caem, as formidáveis portas se abrem; os traidores perecem; os inimigos desaparecem; a cidadela já não existe; a liberdade renasce... Glória eterna ao Deus Todo poderoso que nos propiciou tal liberdade abrasando nossos corações com os santos ardores do patriotismo, dirigindo ele mesmo nossas operações, determinando nossos êxitos.

Chaix enaltece a figura de Claude Fauchet por sua condição de vencedor da Bastilha e sacerdote zelosamente evangélico:
Ó, tu, gênio sublime (o abade Fauchet, a quem havia sido concedida uma coroa cívica) que, prestando aos Mártires da liberdade homenagem dos sentimentos da Pátria, sofreste as contrariedades impostas pelos vis mercenários ou pelos covardes aduladores do despotismo, que não hesitaram em citar-te perante o Tribunal da Religião, desfrute para sempre das honras que mereceu tua alma cidadã. Que sejam nova joia da coroa imortal que te prepara a própria Religião, que sempre defendeste com vigor ${ }^{4}$.

Fora o carisma revolucionário de alguns de seus pregadores no começo da revolução, a Igreja católica concentrou o desempenho de seu papel de protagonista nas cerimônias de bênção e ação de graças de inspiração patriótica. Bênção de estandartes, missas fúnebres, Te Deum e algumas procissões como a de Santa Genoveva. Um ex-voto da tomada da Bastilha foi colocado ao lado do relicário de Santa Genoveva. Robinet ${ }^{5}$ destaca que a guarda nacional contava com muitos sacerdotes, que todos faziam parte da administração de seu distrito (subdivisão do departamento) e que outros tantos tinham cargos municipais. Da mesma maneira, as igrejas e os púlpitos eram utilizados por funcionários civis ou militares para assembleias políticas diversas.

As missas dedicadas ao Espírito Santo haviam precedido as eleições dos Estados Gerais; a abertura dos Estados em Versalhes também fora precedida por uma missa; em todas as paróquias cantou-se um Te Deum depois do decreto que abolia os privilégios feudais (4 de abril de 1789); a troca de bandeiras, a fidelidade à revolução e à primeira constituição também foram religiosamente solenizadas em Notre-Dame.

A resistência contra essa nova afirmação de vanguardas religiosas e políticas fez-se sentir tanto de um lado como de outro, ${ }^{6}$ mas, até a implementação da Convenção, não se pode falar de uma clara ofensiva contra o catolicismo, ofensiva que, no entanto, foi impotente contra a posição de Grégoire, exemplo de fervor revolucionário, amor às artes e resistência evangélica.

\footnotetext{
${ }_{5}^{4}$ Idem, pp. 5, 13, 20, 21.

5 Dr. ROBINET, Le Mouvement Religieux à Paris Pendant La Révolution, T.I, La Révolution dans l'Eglise, Paris; 1896, p. 106.
}

${ }^{6}$ Idem, p. 109 
A Basílica de Sainte Geneviève foi claramente um expoente da colaboração e celebração religiosa dos primeiros acontecimentos da Revolução, notadamente da tomada da Bastilha. A construção da nova Igreja, que se deve ao gênio de Soufflot, começou em setembro de 1764. Ao que parece, depois de uma cura obtida por Luís XV graças à intercessão da padroeira de Paris, em 1744, a abadia de Sainte Geneviève instou o rei a patrocinar a edificação de uma nova igreja, já que a da época ficara pequena ante a enorme afluência de devotos da santa. $\mathrm{O}$ rei concedeu, por aquele período, um aumento do preço das loterias, que se destinaria à construção da nova igreja sob a direção de Soufflot, arquiteto do rei.

O registro de cerimônias da abadia $^{7}$ nos fala do rei, da rainha e da família real sendo recebidos em 1779, quando então o abade dirigiu as seguintes palavras ao rei:

É um grande espetáculo para a Religião ver vossa majestade aproximar-se deste antigo templo para dar graças ao Altíssimo ... O Templo onde repousam as cinzas da poderosa protetora de vosso Reino foi, Senhor, o primeiro que os reis que vos precederam consagraram à glória do Deus dos exércitos; mas o que agora se ergue e que já impressionou os olhos de vossa majestade será um monumento eterno de vossa magnificência e da do rei vosso avô. E vosso reinado, Senhor, parecido ao de Salomão, será tão ilustre pela realização completa dessa obra tão grande como pela alta sabedoria que já faz a felicidade de vosso povo e a admiração do Universo.

Esse monumento de Soufflot acabaria sendo o Panteão de Quatremère de Quincy. Dez anos depois de acolher o rei; o abade ordenava, como em outros lugares, preces para os Estados Gerais e, em 15 de julho de 1789, o abade mandava celebrar uma missa solene seguida de um Te Deum de ação de graças pela tomada da Bastilha. Embora o mesmo tenha sido feito em outros lugares, a celebração de Ste. Genevieve assume significado especial devido a sua antiga relação com a monarquia, sua popularidade como santuário e sua pronta iniciativa de benzer estandartes das novas "milícias burguesas":

7 Reserva da biblioteca de Ste. Geneviève, Ms. 1174, Registre des cérémonies extraordinaires de l'Abbaye de Ste. Geneviève, fls. 1, 116, 151, 175, 237, 151-152, 244-245, 249,251 , etc.
Viu-se neste registro, às folhas 240, com data de 30 de abril de 1789 , o mandato do Rev. P. Abade que ordena Preces na Igreja de sua abadia para os Estados Gerais. Confiávamos então que o céu, sensível a nossos males, dignar-se-la a lhes pôr fim fazendo soprar o espírito de paz e união sobre todos os membros desta augusta assembleia. Entretanto, já haviam transcorrido dois meses, e as três ordens que' a compunham, longe de chegar a um acordo, pareciam mais propensas do que nunca a uma ruptura aberta...

O redator do registro narra a seguir a sucessão de acontecimentos que julga pertinentes ao desenlace que por fim descreverá; a exoneração de Necker, "ministro que era então o ídolo de todo bom francês, que nele via o gênio tutelar da pátria"; a criação de um exército de apoio à aristocracia para intimidar os parisienses; a sublevação de 20.000 cidadãos para garantir a posição do rei, sua neutralização pela tropa circundante; a organização de "patrulhas burguesas"; a ameaça à abadia de Ste. Geneviève devido ao rumor de que em seu interior estariam escondidos armas e trigo, ameaça oculta sob o oferecimento diplomático dos serviços da abadia à Assembleia; a ocupação das ruas de Paris por hussardos e bandidos...

Há dois dias vivíamos entre o temor e a esperança quando vários tiros de canhão, que pareciam proceder do lado da porta de St. Antoine, anunciaram-nos que a milícia burguesa, com a ajuda do Regimento da Guarda, assediava a Bastilha. Atacar esse monumento do despotismo, vencê-lo e ali içar o estandarte da liberdade foi, para nossos valentes concidadãos, a façanha daqueles dias... nosso capítulo foi o primeiro a mostrar seu júbilo com o canto do Te Deum que o Rev. P. Abade entoou com hábito de coro.

No sábado, às seis da manhã, descobriu-se a frente da arca de santa Genoveva ao som dos sinos... O Rev. P. Abade celebrou de pontifical uma missa solene de ação de graças com a presença de autoridades e da milícia... Uma vez terminada a missa, entoou se um De Profundis em contratom para o repouso da alma do francês generoso que, no assédio da Bastilha, selou com seu próprio sangue a liberdade reconquistada.

Ao terminar a cerimônia, o comitê do distrito de St. Etienne foi cumprimentar o padre abade e felicitou-o pela prova de patriotismo dada pela comunidade. Depois desta cerimônia vieram outras: em 3 de agosto de 1789, o grupo burguês do distrito de Vaugirard compareceu para apresentar 
sua bandeira a Ste. Genevieve; em 16 de agosto, cantou-se um Te Deum por ocasião das deliberações da Assembleia Nacional (três dias antes, a Assembleia Nacional concedia ao rei o título de "Restaurador da liberdade francesa"); em 13 de setembro, obedecia-se à ordem real de rezar pela calma no reino...

As donzelas do distrito de St. Etienne também organizaram uma procissão com a imagem de Sta. Genoveva, em 22 de setembro, quando foi benzida uma bandeira para ser entregue às autoridades do distrito.

As cerimônias religiosas continuaram a partir de 1790 em estreita colaboração com as autoridades municipais. Assim exprimia-se o prefeito, em janeiro do mesmo ano, em carta dirigida ao abade:

\section{Senhor,}

Tudo é igualmente antigo (no manuscrito original, primeiro havia sido escrito respeitável, ao invés de antigo, palavra depois apagada) e Santo nesse lugar consagrado pela piedade. Esses templo é objeto de uma longa e constante veneração... a prefeitura empregará seus bons serviços para manter-vos em vossos direitos e no Serviço do Templo a que estais consagrado, e seu desejo será manter sempre a colaboração entre o corpo municipal e vossa Igreja.

Essa colaboração não ultrapassaria o início de abril de 1791, quando foi realizado o traslado dos restos mortais de Mirabeau. Depois se transformaria no Panteão, apesar de algumas reticências por parte dos vários defensores do catolicismo.

Louis Héron, que se distinguiria por uma obsessão cúmplice do terror, foi prudente e respeitoso com a Igreja católica no que tange aos planos de transformação da nova igreja de Ste. Geneviève:

O entusiasmo é, com frequência, a perdição do espírito e da razão. É o caso de M. Villette, que pediu o traslado das cinzas de Voltaire para a nova Igreja de Ste. Geneviève. Seu caso é desculpável. Era parente de Voltaire e o filósofo nascera cristão. Mas será uma política salutar modificar o destino desse novo templo erigido para honrar o Deus dos católicos, sob a invocação da padroeira de Paris, e transformá-lo no templo da gratidão nacional em homenagem aos grandes homens que iluminaram a França? Depositar ali suas cinzas sem considerar que em vida pertenceram a diferentes religiões? Seria conveniente fazer isso com tal Igreja, a segunda da diocese e votada a ser uma das paróquias mais fortes de todo o Reino?... Seria mais adequado dispor para essa finalidade do Campo da Federação, para onde deveriam ser levadas as cinzas de Mirabeau e, depois, as dos grandes homens que melhor tiverem servido a nação. Haveria melhor lugar para os túmulos de Voltaire e de Rousseau que a entrada desse circo?

Adotando-se tal plano não se fere a nenhuma opinião religiosa, podese fazer uma cripta nesse vasto campo, subdividida em diferentes confissões, seguindo, assim, os vivos e os mortos suas variadas opções, coisa que não pode ser feita em Ste. Geneviève. ${ }^{8}$

Héron conclui seu texto pedindo respeito para o catolicismo em consideração ao seu papel de religião dominante na França.

Prudhomme e outros redatores de Révolutions de Paris atacariam mais tarde o catolicismo manifestado em Ste. Geneviève de acordo com a política dominante na Comuna de Paris do ano II da República. ${ }^{9} \mathrm{O}$ culto da padroeira de Paris, objeto de tanta veneração no início da Revolução, é vilipendiado a este ponto:

Pois bem! Será possível acreditar no que ocorreu na festa de Sta. Genoveva? Sua arca foi descida ${ }^{10}$ como se a santa não tivesse o braço suficientemente longo para fazer milagres lá de cima; quantas camisas, lenços e sudários esfregaram milhares de vezes o féretro de ouro; quantos bons camponeses chegaram dos arredores já na noite anterior à festa para ouvir uma missa de meia-noite perto dessa relíquia, para oferecer-lhe, ou melhor, para oferecer aos padres de St. Etienne, seus numerosos ex-votos; a multidão era tão grande, em meio a este século das luzes, que impediu a entrada na igreja de muitos deles, ficando do lado de fora mais de um milhar; que os guardas nacionais tiveram que pernoitar ali mesmo para manter a ordem, congelando de frio para o prazer dos devotos; que os padres, extraordinariamente orgulhosos por terem atraído toda aquela massa de supersticiosos, pavoneavam-se sob seus coloridos hábitos pontificais. Apenas eles tiraram proveito dessa festa, além de um bom número de ladrões que escamotearam relógios, lenços,

${ }^{8}$ L.-J.-S. HÉRON, Représentations d'un citoyen à la Nation, 1791, p. 1. Héron era cidadão da seção de Ste. Geneviève.

${ }^{9}$ Révolutions de Paris, $\mathrm{n}^{\circ} 182$, de 29-XII-1792 a 5-I-1793, p. 85.

${ }^{10}$ Este era o costume na liturgia da festa. 
cigarreiras. Tudo isto a santa suportou com muita paciência, vendo sua mansão transformada numa verdadeira baiúca, algo de que não se lembrará devido a sua honestidade.

Mas nossa padroeira de Paris suporta muitas outras coisas apesar de dominar os elementos, fazer chover quando chove e fazer aparecer o bom tempo quando brilha o sol. Nossos reis foram transtornando e arruinando Paris no transcurso dos séculos, ela deixou-os agir, como hoje deixa a capital da França à mercê dos intrigantes e facciosos que levantam calúnias nos departamentos. Deveria antes iluminar e guiar os espíritos de todos os franceses. Seria melhor do que todo esse consumo de círios ao redor de seu cadáver, numa época em que o sebo e a cera estão tão caros.

Um padre era censurado por sua jactância no púlpito, contando ao povo tantos milagres que não haviam existido e tantas bobagens. Bem!, dizia ele, dou forragem a meus cavalos, mas eu não a como...

O tom anticatólico será mais forte ainda no ano seguinte, quando os restos de Santa Genoveva serão queimados na praça da Grève, na frente da prefeitura, e suas cinzas atiradas no Sena ${ }^{11}$ :

Fazer dançar marionetes ou realizar peripécias com copos nas praças públicas e à luz do dia não é mal algum; é preciso distrair as crianças e quem as cuida. Mas reunir-se de noite em becos escuros para cantar hinos, queimar cera e incenso em homenagem a um bastardo (tanto Jesus como Moisés e Maomé o foram) e a uma esposa adúltera é algo escandaloso, um atentado aos bons costumes, suspeito em tempo de revolução, e que merece toda a atenção e severidade da polícia correcional. Há dezoito séculos, esse escândalo, que não muda de natureza pelo fato de se transformar em religioso, renova-se todos os anos, de 24 a 25 de dezembro, e ainda não foi reprimido.

Um ato de selo explicitamente cat6lico e favorável à Revolução foi a famosa declaração do abade Sièyes sobre o Terceiro Estado. Declaração que no entanto contempla mais a burguesia da Revolução do que as classes menos favorecidas e mais marginalizadas ${ }^{12}$ :

Quem ousaria dizer que o Terceiro Estado não possui por si mesmo todo o necessário para formar uma Nação completa? É o homem

\footnotetext{
${ }^{11}$ Révolutions de Paris, $\mathrm{n}^{\circ} 183$, de 5 a 12-I de 1793, p. 45.
}

${ }^{12}$ Abbé SIEYÉS, Qu'est-ce que le Tiers-Etat?, Paris, 1789, [2ª ed.], pp. 7, 9, 93, 17. forte e robusto que ainda está com um braço acorrentado. Se a Ordem privilegiada desaparecesse, a Nação não ficaria diminuída, e sim aumentada. Assim, pois, o que é o Terceiro? Tudo, mas um tudo travado e oprimido. O que ele seria sem a Ordem privilegiada? Tudo, mas um tudo livre e florescente. Nada pode caminhar sem ele, tudo andaria infinitamente melhor sem os outros. Não basta mostrar que os Privilegiados, longe de serem úteis à Nação, só podem debilitá-la e prejudicá-la; é preciso provar, ademais, que a Ordem nobre não faz parte da organização social (não estou falando de forma alguma do Clero. Segundo minhas ideias, ele não é uma ordem, mas uma profissão encarregada de um serviço público. Aqui não é a pessoa a privilegiada, mas a função, o que é bem diferente); que pode ser uma carga para a Nação, mas que dificilmente poderia existir como parte dela.

"O que é uma Nação? Um corpo de associados vivendo sob uma lei comum e representados pela mesma legislatura". Assim começava a existência de uma nação nas palavras de Sieyès, mais próximas da ideia de cidadania adquirida no contrato social do que da ideia de pertencer a uma comunidade de costumes. Essa ideia estava em consonância com a de uma integração política do Terceiro Estado como equivalente a sua constituição nacional. Assinalemos mais alguns parágrafos do abade Sieyès:

.. os Representantes do Terceiro Estado terão a procuração incontestável de vinte e cinco ou vinte e seis milhões de indivíduos que compõem a Nação, excetuando-se cerca de duzentos mil Nobres ou Sacerdotes. É mais do que suficiente para que se atribuam o título de Assembleia Nacional. Assim deliberarão, sem dificuldade alguma, para a Nação inteira, com a exceção apenas de umas duzentas mil cabeças.

Não se deve julgar seus pedidos de acordo com as considerações isoladas de alguns Autores, mais ou menos instruídos acerca dos direitos do homem. O Terceiro Estado ainda está bastante atrasado a esse respeito; não digo somente no que tange ao conhecimento dos que estudaram a ordem social, mas também no que se refere a essa massa de ideias comuns que forma a opinião pública. Para apreciar as verdadeiras petições do Terceiro, é preciso ler as reclamações autênticas que as grandes Municipalidades do Reino dirigiram ao Governo. Que nos dizem? Que o Povo está pedindo algo, verdadeiramente o mínimo possível. Quer ter verdadeiros representantes nos Estados Gerais, ou seja, deputados oriundos de 
sua própria ordem, capazes de ser os intérpretes de suas aspirações e os defensores de seus interesses... Não pode comparecer aos Estados Gerais para votar se não possuir uma influência pelo menos igual à dos Privilegiados e, por conseguinte, pede um número de Representantes igual ao das duas Ordens juntas...

Edgar Quinet ressalta a estreita aliança entre a Revolução e a Religião nos primeiros momentos, quando o catolicismo marcha à frente das cerimônias revolucionárias e o discurso revolucionário ou da filosofia da revolução assume uma identidade religiosa considerável ${ }^{13}$ :

Depois do Juramento do Jeu de Paume e da reunião das ordens na sessão da Igreja de São Luís, a filosofia antes de mais nada torna-se religiosa. Encontrando-se próxima ao nascimento de um mundo novo, repete na tribuna o versículo de Maria ao sentir o filho de Deus agitar-se em suas entranhas: "Elevou os humildes e destronou os poderosos" (Discurso de M. Lameth).

Algo surpreendente é presenciar como, num último esforço, o Conselho Executivo escreve a Roma para mostrar à Santa Sé a identidade entre o cristianismo e a Revolução Francesa ("Os princípios evangélicos que respiram a democracia mais pura e a igualdade mais perfeita..." Carta do Conselho Executivo a Roma, 1793). O que o Papa podia pensar ouvindo a teologia da Convenção? $\mathrm{O}$ que tinham em comum dois poderes, um dos quais só reconhecia o espírito ali onde se encontravam as formas, e o outro, rompendo todas as formas, pretendia encontrar e deixar à vista a própria alma da cristandade?

Lamourette foi dos primeiros a esperar da Revolução um fortalecimento do próprio cristianismo. O que mais podia fortalecer a luta solidária e entusiasta contra a opressão? A ideia de igualdade provinha do próprio Gênese, que descrevia a criação do homem à semelhança divina $\mathrm{e}$ sem distinção individual alguma. No Evangelho, a igualdade resplandecia com clareza ainda maior. Ademais, a Revolução se apresentava com exigências morais que deviam animar o cristianismo. ${ }^{14}$

\footnotetext{
${ }^{13}$ E. QUINET, op. cit., 13 lição, pp. 222, 228.

${ }^{14}$ Abbé LAMOURETTE, Prônes civiques ou le pasteur patriote, Paris, 1790-91, p. 12, e Prône IV, VI, etc.
}

No entanto, sendo já bispo constitucional de Lyon, Lamourette discordará de Fauchet acerca da ideia de uma religião nacional para a França:

... declarar nacional a religião cristã teria sido uma desnaturalização do caráter mais íntimo e essencial do cristianismo... Vocês compreenderiam, irmãos meus, o que eu estaria querendo dizer se lhes falasse de uma consciência nacional?... Existem verdades nacionais?

Segundo Lamourette, ${ }^{15}$ o poder nacional deve organizar civilmente a religião, mas não pode confundir a existência civil (exterior e legal) da religião com a existência de seus dogmas e de sua espiritualidade.

\footnotetext{
${ }^{15}$ Idem, p. 29.
} 


\section{Jansenismo, Galicanismo, Republicanismo e Revolução. A Constituição Civil do Clero}

Surge uma ruptura entre o neojansenismo, o galicanismo e o cristianismo iluminista, de um lado, e o cristianismo evangélico e revolucionário de outro, mas também existem elementos - sobretudo de caráter político - comuns a essas tendências que, durante a revolução, tenderão a ser vistas como opostas. Assim nos assinala Boussoulade ao destacar a continuidade entre ambas as correntes, referindo-se ao presbiterianismo associado às reivindicações do baixo-clero e ao galicanismo na forma como a Constituição Civil do Clero estabelece divisões e relações hierárquicas. ${ }^{1}$

Neste sentido, interpretou-se que a Constituição Civil do Clero satisfazia às aspirações de parte do jansenismo e do galicanismo anteriores à Revolução. $\mathrm{O}$ neojansenismo também aflorou em alguns Cahiers de Doléances: :

Os Estados Gerais foram convocados não apenas com vistas a deliberar acerca dos meios para restabelecer as Finanças, mas também para regenerar a Nação... neste intuito não se pode esquecer que a Religião vem à frente.

Deve-se, portanto, pedir que esta Religião, a única verdadeira, seja eficazmente protegida contra os ataques da Filosofia moderna, cujas máximas tendem a derrubar igualmente o Trono e o Altar. Esta Religião é, por outro lado, tão útil à Sociedade que se não existisse, e se a fragilidade do espírito humano pudesse inventar essa obra-prima da Sabedoria divina, a Política saudável deveria inventá-la... Deve-se partir do princípio de que não haverá verdadeira moral onde não houver Religião, e que a indiferença para com a Religião equivale à destruição dos bons costumes.

${ }^{1}$ J. BOUSSOULADE, "Le Presbytérianisme dans les conciles de 1797 et de 1801", em AHRF, n2 121, 1951.

Cadernos de Queixas. (N. da T.)

${ }^{2}$ Projet de Doléances en faveur de la Religion aux Etats-Généraux de 1789, começo e pp. 4,
Os abusos que a malignidade ou a falsa Filosofia sem dúvida exageram procedem principalmente de duas causas: da falta de um poder do clero que lhe permita reformar a si mesmo depois que cessarem os Concílios Provinciais e nacionais, e da nomeação para os benefícios.

Essas Doléances, de inspiração jansenista, consideravam o poder dos sínodos o mais apropriado para a gestão saudável dos bens eclesiásticos, e o sistema de benefícios essencialmente um nepotismo modificável, conforme uma combinação de méritos dos candidatos.

O jansenismo ou neojansenismo também foi avaliado como causa da boa acolhida que o catolicismo reservava à Revolução. ${ }^{3}$ No entanto, a posição política dos Jansenizantes às portas da Revolução não permite que tal afirmação seja generalizada, muito pelo contrário. A recordação conservada por Grégoire do filojansenismo de Port-Royal pode parecer alinhada com seu pretenso aburguesamento revolucionário mas, por outro lado, o embate revolucionário do baixo-clero mostra-se totalmente desvinculado das influências dos jansenismos. Só se pode estabelecer um paralelo considerando-se que tanto a espiritualidade neojansenista como a do evangelismo revolucionário eram favoráveis a um retorno à pureza atribuída aos tempos primitivos da Igreja, pureza visível sobretudo através da vida e das ações dos pastores de almas.

A Constituição Civil do Clero pressupôs uma organização e um controle da Igreja da França que, sem reduzir a autonomia eclesiástica, já haviam sido pensados em parte por galicanos e vários neojansenistas. A revolução insistia ainda mais no retorno à sobriedade cristã e na integração patriótica do clero.

Nessa crise geral, os representantes da nação francesa, empenhados na regeneração do Império, voltaram seus olhos para a triste situação do Clero e deram-lhe uma Constituição Civil que realiza, de uma só vez, um retorno à antiga ordem do regime exterior do culto e mais reformas em seus membros que os séculos precedentes sequer

${ }^{3}$ Louis BLANC, Histoire de La Révolution Française, Paris, 1866, p. LXXXII. 
haviam podido imaginar, cujo êxito nem os Concílios tinham ousado prognosticar. ${ }^{4}$

A reforma atingiu dois objetivos principais: a nacionalização dos bens do clero e a redução de seu número, com uma nova divisão territorial eclesiástica.

O decreto da Constituição Civil do Clero, de 12 de julho de 1790, estabelecia uma escala de retribuições bastante desigual entre os membros do clero católico. Assim, enquanto eram alocadas 50.000 libras ao bispo de Paris, aos demais bispos cabiam entre 10 e 20.000 libras, conforme a população. Aos sacerdotes de Paris, 6.000 libras, e aos demais de 4.000 a 1.200 , conforme a população. Os vigários recebiam entre 700 e 2.400 libras, se fossem de Paris. O clero de Paris foi o mais beneficiado, pois o baixo-clero das províncias se sustentava com uma renda inferior a pelo menos a metade do que recebiam os sacerdotes nas paróquias parisienses.

Eis a apologia do juramento cívico feita por um sacerdote no quadro da nova Constituição francesa que inclui a civil do clero (Artigo 5 da Constituição de 1791):

O sacerdócio estava envilecido; a corrupção dos costumes chegara ao máximo. Embora acreditar que necessitávamos de uma grande revolução para sair desse estado de letargia fosse um horror, temos de convir que era pelo menos uma bela ilusão cuja veracidade não deixava de ser desejável. Numa crise como aquela era de temer-se tudo, não resta dúvida; mas eis que finalmente nossos medos se dissipam. Sim, a Religião Católica vai ser, da maneira mais solene e mais duradoura, e sem necessidade de decretá-lo, a Religião dominante, a Religião Nacional, a Religião do Estado, sustentada à sua custa e, por assim dizer, incorporada a ele. Para tanto só é mister jurar o respeito à nova Constituição. ${ }^{5}$

$\mathrm{Na}$ continuação deste mesmo texto, o autor destaca a independência dos sínodos convocados pelo bispado em relação à Santa Sé.

${ }^{4}$ CHARRIER DE LA ROCHE, Examen des Principes sur les Droits de la Religion, la Jurisdiction et le Régime de l'Eglise Catholique, relativement à l'influence de l'Autorité Séculière dans la Constitution Civile du Clergé, Paris, 1790, p. 15.

${ }^{5}$ Apologie du serment civique, par un prêtre (Daucel?) de la maison et Société de Sorbonne, Ami de la Religion et des Loix;, p. 5.
O juramento da Constituição Civil do Clero, tal como era feito a partir de 27 novembro de 1790, consistia na fórmula abaixo:

Juro ser diligente na custódia dos fiéis da diocese ou da paróquia que me foi confiada, ser fiel à nação, à lei e ao rei e manter com todo o meu poder a Constituição decretada pela Assembleia Nacional e aceita pelo rei.

A partir de 14 de agosto de 1792, a fórmula passou a ser a seguinte: "Juro ser fiel à nação e manter a liberdade e a igualdade, ou morrer defendendo-as". Logo foi criada uma variante definitiva: "Juro ser fiel à nação, manter com todo meu poder a liberdade, a igualdade, a segurança das pessoas e das propriedades, e morrer, se for necessário, pelo cumprimento da lei. ${ }^{6}$

Richard Chaix, como capelão de Salpêtrière, pronunciou seu juramento cívico sintetizando exemplarmente a irmanação inicial do cristianismo em suas exigências ascéticas à revolução em suas exigências morais ${ }^{7}$ :

A Religião! Ah, senhores, ela é a benfeitora da humanidade; quebra o cetro dos tiranos, derruba seu trono, reclama os sagrados direitos do povo e o vinga da opressão. Se a religião estivesse em perigo (a fé não se apaga de todo no povo), seriam bons cidadãos os que a defendessem. Porém, longe de atentar contra a religião, nossos representantes não procuram senão restabelecer sua pureza original e seu esplendor primitivo. Adiro de plena vontade a tão nobre iniciativa. Só pode ser inspirada pelo espírito de Deus, só pode ser concebida pelos mais fiéis zeladores do bem público; e neste ato solene do qual sois testemunhas, irmãos meus, concidadãos, tenho a doce satisfação de sentir que sirvo ao mesmo tempo a minha religião e a minha pátria.

\footnotetext{
${ }^{6}$ Para a objeção de consciêncla a estes juramentos, ver J. MEILLOC (Uzureau ed.), Les serments pendant La Révoiution, Paris, 1904.
}

${ }^{7}$ La Bouche de Fer, ${ }^{\circ}$ 11, de 27-1-1791, p. 171. 


\section{Grégoire: a integridade evangélica e jacobina}

Dentre as grandes figuras da Revolução Francesa, uma das maiores, uma das mais belas, e sem dúvida para toda a História, é a do abade Grégoire. Sacerdote sagaz ao observar a natureza humana, indômito em matéria de doutrina e fé, viveu intensamente todos os problemas de seu tempo, utilizou toda sua autoridade moral para construir as estruturas de uma cristandade que vivesse em unidade com o ideal revolucionário.

Assim Albert Soboul ${ }^{1}$ nos apresenta esse sacerdote que exigiu tanto respeito da Revolução para com a Religião quanto desta em relação àquela

Grégoire encara o início da Revolução de acordo com a tradição da própria Igreja ${ }^{2}$ :

Na Idade Média, o sacerdócio limava os grilhões do feudalismo, já que não podia parti-los; dominando a opinião pública, estabeleceu à época a Trégua de Deus, a fim de que os servos pudessem pelo menos respirar enquanto o demônio da guerra percorria a terra, assolando-a. Hoje em dia, senhores, a humanidade sofredora se refugia sob vossas asas suspirando pela felicidade. Vossos olhares voltam-se para nós e nossas almas estremecem diante do surgimento de vossas penas, mortais desafortunados, que a providência confiou a nossa ternura; o que poderíamos amar se vós não fôsseis os objetos de nossa predileção? Não somos vossos pais? Não sois nossos filhos? Quantas privações tivestes que suportar para participar dos gastos de uma Assembleia na qual repousam vossas esperanças! Desses campos regados com vosso suor, vossos ardentes desejos se elevam aos céus e santificam vossas fadigas. Dóceis à voz dos ministros que nos substituem, conservai fielmente em vossas famílias o repositório das santas verdades e das virtudes cristãs que recebestes de nós. Quando vossos emocionados corações se despediram de nós com tanto sentimento, confiastes vossos interesses ao nosso zelo; ah! se nossos esforços forem coroados de êxito, já não devereis dobrar-vos sob o jugo da opressão; uma bela liberdade alimentará vossos anos; vossas bênçãos acompanharão nossos passos; vossos filhos

\footnotetext{
${ }^{1}$ Oeuvres de l'abbé Grégoire, Liechtenstein, 1977. Prólogo de Albert Soboul.
}

${ }^{2}$ Nouvelle Lettre d'un Curé à ses confrères, députés aux Etats-Généraux, 1789. depositarão em nossos túmulos o sentimento de uma gratidão hereditária. Sua felicidade e os fatos da história dirão aos homens do futuro que os sacerdotes franceses convocados por seu Soberano à assembleia da Nação mostraram-se tão dignos como sacerdotes da Pátria, quanto da Religião.

Como membro da Convenção em missão, Grégoire aborda assim a reforma que a Constituição Civil do Clero deve acarretar ${ }^{3}$ :

Cidadãos, colocai de um lado o antigo regime com seus abusos, seus abades comanditários, aqueles ricos benefícios devorados por homens cujo menor defeito era serem inúteis. Do outro lado, mostra os pastores reconduzidos à antiga e respeitável simplicidade do cristianismo e, com o Evangelho na mão, escolhei; não há confusão possível. Ah! se essas felizes mudanças tivessem ocorrido há dois séculos e meio atrás, nossos irmãos protestantes, aventando a palha, não teriam apartado o bom grão; satisfeitos ao verem os abusos extirpados, não teriam atacado o dogma, e agora não teríamos de deplorar sua separação: mas também agora basta-lhes dar apenas um passo para regressar ao convívio da verdade e de seus irmãos; nossa amizade lhes estende os braços e talvez esteja se aproximando o instante em que se realizará a feliz reunião.

Em última análise, toda a disputa sobre a Constituição Civil do Clero reduz-se a esta simples consideração: a República vos diz: tudo que se refere aos dogmas da religião católica permanece intacto, e não temos nem o poder nem a vontade de alterá-lo; mas não deve haver dogma algum que seja ensinado por um pastor e não por outro; e se com o juramento não obtivermos de vós uma garantia de vossa submissão às leis do Estado, a segurança pública exige que os despojemos de vosso ministério; já que passando de uma paróquia a outra um fiel pode mudar de pastor, o estado pode mudar todos os seus funcionários civis; e não seria absurdo o fracasso da vontade de um povo inteiro devido ao capricho e à imoralidade de um único sacerdote que fosse necessário expulsar de seu lugar?... Uma multidão de sacerdotes veneráveis prestou o juramento de todo o coração; atualmente são o melhor ornamento da Igreja. Mas não nos pode passar desapercebido que um certo número dos que aparentemente acataram as leis do Estado as desobedecem

${ }^{3}$ Adresse aux Citoyens des campagnes du Département du Mont-Blanc (Para o cidadão Gregóire, deputado à Convenção Nacional). 
secretamente e exortam à contrarrevolução, e quando as almas timoratas se enchem de medo, optam por um silêncio criminoso que os acusa indefectivelmente. Acreditam fazer muito fechando-se em seu silêncio, e é precisamente nisto que são condenáveis, já que seu ministério e a caridade cristã exigem que levem paz às consciências inquietas. Teria sido melhor que tais homens tivessem se alinhado com os rebeldes. Esses patriotas pela metade são infinitamente mais desprezíveis, mais perigosos, do que os aristocratas declarados.

Quanto aos que se mostraram refratários à lei do juramento cívico depois de já tê-lo prestado, foi a imitação, não a reflexão, que os fez decidir. São homens sem caráter, que, incapazes de interrogar a própria razão, antes de tomar partido precisam ver o que fazem os outros. Ao invés de se aprofundarem numa discussão e extrair a verdade, são subjugados pelos chefes de bando, quer dizer, pela maioria dos bispos franceses que, nos dias de orgulhosa prosperidade, colocavam-se a grande distância de seus padres e que de repente aproximaram-se deles para multiplicar seus partidários.

Concentrando até há pouco tempo atrás os benefícios, devoraram cem mil libras por ano que tantos pobres lhes proporcionavam, desperdiçavam-nas em Paris, nas antecâmaras de Versalhes, longe de sua diocese onde o bispo mal era conhecido. Essa conduta era certamente contrária à religião e, no entanto, nada diziam sobre ela esses mesmos homens em quem agora, de repente, despertou grande zelo religioso. Mas não conseguem nos persuadir de sua boa-fé com uma conduta tão escandalosa e recente.

Que comiseração não causa ver essa horda de emigrados composta até agora de senhores, parlamentares, financistas, cortesãos e príncipes que ultrajavam os bons costumes, canonizavam a libertinagem e que, na atualidade, fazem alarde de seu fervor religioso...

Mas Grégoire não é um adepto incondicional da Revolução em geral. Estabelece distinções e discerne, como outros revolucionários, as que lhe parecem ser novas injustiças no quadro da França revolucionária ${ }^{4}$ :

O pudor foi violado; o império dos bons costumes foi ultrajado até na choça do pobre; e, ao lado ou sobre as ruínas de sua choça arrasada, o

\footnotetext{
${ }^{4}$ Rapport présenté à la Convention Nationale, au nom des Commissaires envoyés par elle,
} pour organiser les Départements du Mont Blanc et des Alpes Maritimes, Paris, 1793. infortunado cidadão viu-se reduzido senão a chorar sobre sua mulher, seus filhos e seus farrapos: todos os dias nossos corações têm sido partidos com o relato desses crimes e com o quadro das misérias que assolam a maioria das comunas. Nós nos censurávamos, para dizer de alguma maneira, por comer enquanto uma multidão de irmãos nossos estavam prestes a morrer de fome. Essas infâmias cometidas nas cabanas das montanhas, nas desgraçadas vilas de Lantosque, Lévens, Lucerame e, sobretudo, Sospella que, depois de ter sido tomada retomada cinco e seis vezes, já não tem senão os muros; esses horrores levaram ao desespero e provocaram múltiplas vinganças: muitos desses infortunados, vendo suas famílias arrastadas na miséria, foram buscar no exército inimigo o pão ou a morte.

De que serve pregar a liberdade, quando esta é tomada odiosa por tudo que a lubricidade tem de mais desenfreado e a pilhagem de mais exasperante? De nada servirão os discursos pomposos sobre a liberdade; à falta de conhecimentos, os povos possuem aquele toque da natureza que não engana; jamais perceberão a liberdade fora da lei, do altar da pátria, e, nas palavras de um poeta, do templo da virtude.

Tais são as causas que, neste departamento e em países estrangeiros, fizeram diminuir o crédito dos saldos, tomaram o patriotismo minguado e os povos amargurados, sufocaram as boas disposições revolucionárias e teriam feito a liberdade na Europa retroceder talvez meio século se o desastre geral das finanças não acelerasse seu êxito por toda parte.

Esses crimes serviram de pretexto para caluniar uma nação generosa, julgada pelas más ações de alguns indivíduos que ela mesma abomina.

Não há um único camponês na Itália a quem não se tivesse persuadido de que o latrocínio, a violação e o assassinato eram crimes comuns entre os franceses...

Grégoire afirmou seu cristianismo e seu catolicismo ao garantir todas as suas prerrogativas como sacerdote perante a constituição civil e desafiar os convencionais que, num dado momento, sob a hegemonia dos 
hebertistas, queriam acabar com a religião católica organizando todo um cortejo de apostasias:

... quando o bispo de Paris escandalizou a Igreja com uma covarde e propalada apostasia, em meio às vociferações do ateísmo e apesar dos ultrajes que me assediavam, declarei-me fiel ao caráter de católico e de bispo. Não sabeis a que ponto esgotaram-se comigo à época alternadamente promessas, ameaças e todos os recursos da astúcia, da adulação e da perversidade. Confessando Jesus Cristo, pensei estar pronunciando minha sentença de morte; durante um ano, o cadafalso aparecia incessantemente diante de meus olhos e o prosseguimento de minha existência ainda hoje me causa a surpresa da novidade.

Gemendo na solidão de meu coração, invoquei a ressurreição da justiça; assim que pude reclamar utilmente os direitos arrebatados pela tirania, pedi a liberdade de culto; esta petição, que atraiu sobre mim novos ultrajes, obteve contudo alguns resultados positivos ( $a$ liberdade de culto é efetivamente proclamada em fevereiro de 1795).

Durand de Maillane, que a posteriori ${ }^{6}$ mostrou-se bastante severo para com a trajetória revolucionária da religião, opinou a favor de Grégoire. Ao referir-se à sessão da Convenção que obteve a apostasia do bispo de Paris, Gobel, disse:

Nessa mesma sessão, os deputados da Montanha solicitaram vivamente a M. Grégoire que subisse à tribuna como os outros, coisa que recusou com tenacidade. Foi ameaçado, e as ameaças da Montanha eram, à época, sentenças de morte. M. Grégoire as desafiou e adquiriu assim a meu ver o título de confessor de Jesus Cristo.

Quinet diz, comentando a integridade de Grégoire:

$\mathrm{Na}$ cara desses renegados, no momento mais terrível, o abade Grégoire faz abertamente sua profissão de fé católica à tribuna da Convenção; não houve coragem maior do que essa numa época que a demonstrou das mais diversas maneiras. A Convenção se irrita, sem ir mais longe, com o desafio desse cristão. Roma guarda seu rancor

${ }^{5}$ Lettre pastorale de H. Grégoire, Evêque du Diocèse de Loir et Cher, Paris, 12-III-1795 (22 do ventoso do ano III), pp. 2, 4, 9.

${ }^{6}$ MAILlANE, Durand de, Histoire de la Convention Nationale, Paris, 1825, p.182. contra ele, que não fugia do martírio; o abade Grégoire, perdoado pelos grupos que desafia, permanece anatematizado pela Igreja que reanima.

Criticando a perseguição religiosa, Grégoire usa argumentos próximos aos de Robespierre ${ }^{8}$ :

De todas as perseguições que afligiram a Igreja da França desde suas origens, nenhuma reuniu tanta violência e tanta barbárie como a última. Se todos os cultos foram atacados por homens que não gostam de ninguém, a religião católica foi objeto especial de seu ódio e, muitas vezes, ao atacar as demais, limitaram-se a hostilidades fictícias, assestando os golpes mais certeiros no catolicismo.

Se os inimigos da religião tivessem tido o mínimo sentimento do pudor da justiça, ou apenas aquilo que chamamos de educação, não teriam ultrajado as opiniões religiosas nem os objetos de culto ...

Um exército de bandidos, composto em parte por padres apóstatas, investia com furor contra as igrejas, destruía as obras-primas da arte, os monumentos da piedade, exercia o saque e vomitava blasfêmias...

... Em nossas igrejas devastadas, que o delírio chamou de templos da Razão, prostitutas, com o nome de deusas da razão, mancharam os altares do Deus vivo; e nesses púlpitos, em que tantas vezes vossos pastores haviam pregado em nome do céu o amor à virtude, o crime pregou o ateísmo: pois o crime tem necessidade do ateísmo para afogar seus remorsos; o crime teme a ideia de um Deus, esta ideia consoladora que, ao sair de vossas cerimônias religiosas vos acompanha à casa, ao vosso trabalho e que, no espantoso isolamento em que a destruição dos cultos vos mergulhou, manteve vossa esperança e suavizou vosso infortúnio.

Os perseguidores iam até mesmo às casas semear o pânico, desolar as famílias e fazer desaparecer todos os livros que pudessem despertar sentimentos religiosos. Em várias regiões da França foram vistos arrancando os crucifixos das mãos dos moribundos ou agravando seu sofrimento e apressando sua morte com as imprecações mais ferozes.

Então os laços sociais se afrouxaram e quase romperam-se totalmente. Só houve segurança para os maus. Os virtuosos viram-se

\footnotetext{
${ }^{7}$ QUINET, op. cit., t. III, p. 229.

${ }^{8}$ Vide Nota 5.
} 
perseguidos até o refúgio do pensamento, amargurados em plena vida. Os que foram enviados ao último suplício viram-se privados do socorro da Religião, que em nenhum país se recusa a qualquer homem nos últimos momentos de sua existência; e os que a morte ceifara eram transportados para o túmulo com uma indiferença que se assemelhava à dos brutos, ao passo que em todos os povos um respeito religioso acompanha ao túmulo os restos da humanidade.

Qual era seu objetivo? Queriam aniquilar todos os princípios que, orientando os homens para o bem, são uma censura constante para os maus. Queriam saquear sem obstáculo algum e tentar a contrarrevolução aproveitando-se da agitação do povo.

... Os cem mil foragidos, que foram o flagelo e o pânico da República, não conseguiram arrancar de nossos corações nem o amor à religião nem à liberdade; transmitiremos às gerações seguintes essa dupla herança. As naves da República e da Igreja, desafiadas pelas tempestades, singrarão juntas sem soçobrar e chegarão a bom porto.

Que a religião renasça entre nós! Que renasça tal como saiu das mãos de Jesus Cristo, tal como existiu nos primeiros séculos, naqueles dias de sua glória! Gostamos de levar nossos pensamentos até aqueles tempos felizes, concebendo a esperança de vê-los renascer. A fogueira da perseguição, consumindo às vezes o bom trigo, também devorou o joio que crescia no campo do Senhor. Assim, a terra fertilizada pela combustão das plantas parasitas, que embruteciam sua superfície, cobre-se de ricas messes. Por assim dizer, a origem da Igreja torna a nos vivificar, anunciando uma época de piedade verdadeira, assim como o retomo da primavera nos anuncia o despertar da natureza.

Grégoire conclui com a ideia grata aos católicos revolucionários, exposta com veemência por Fauchet, da superioridade do cristianismo em relação à nova ideia do homem que se afirma com a Revolução:

Onde encontrar uma religião que dê uma ideia mais sublime do homem, de sua dignidade, e que lhe apresente uma moral mais pura e esperanças mais consoladoras? Filha do céu, dele desce, não para tiranizar os mortais, como diz a calúnia, e sim para conduzi-los à felicidade por meio da virtude. Aplica sua solicitude e seus cuidados a todas as épocas da vida; cuida do homem desde o berço, zela por sua infância, se apresente diante de sua razão nascente para esclarecê-lo no caminho da vida, abençoa suas uniões, regulamenta suas iniciativas e preside a todas as suas ações.

Em cerimônias cobertas de emoção invoca a fertilidade para nossos campos, a liberdade para nossa pátria; bendiz o céu por seus dons; roga pelos que o ultrajam; entra nas choças, desce às masmorras para consolar os que sofrem; comparece à cabeceira do doente e o prepara para a eternidade. Acompanha-o além dos limites da vida e, com invisível corrente, enlaça a felicidade das raças extintas à das atuais e futuras.

Se, como foi dito, os detratores do Evangelho tivessem ouvido de um pagão o sermão da montanha de Jesus Cristo ou o que dirigiu a seus discípulos antes de morrer, com que entusiasmo teriam elogiado seu caráter sublime!

E mais uma vez Grégoire afirma, como Robespierre, o poder da fé religiosa sobre os possíveis (para eles necessários) condicionantes morais da política:

A lei humana, que só pode deter o braço, não pode atingir a multidão de vícios destruidores da ordem pública; a religião os ataca em sua própria origem, condenando inclusive seu pensamento ou sua imaginação. A religião é o suplemento necessário à insuficiência das leis humanas, é a base mais sólida da garantida da vida social.

Assim, o evangelho, em todos os lugares onde penetrou, humanizou os povos, melhorou a sorte dos desditosos, avivou o gênio das artes e consolidou a existência da cidadania política. É justo imputar-lhe os vícios que não pode impedir e, em troca, não levar em conta os que reprime, assim como as virtudes que gera?

Com Grégoire, estamos diante de um exemplo, quase único de preocupação não só com os aspectos mais próximos (nacionais) e mais numerosos (camponeses, peões) da questão social da época, mas também com os marginais (minorias religiosas e raciais) e com os "periféricos" ou dependentes num espaço distante da influência do sistema social dominante, como é o caso do escravismo ${ }^{9}$. Ou seja, Grégoire, fiel a sua ação cristã e revolucionária, enfrenta tanto a injustiça derivada das relações

${ }^{9}$ Brissot já havia fundado uma sociedade de amigos dos negros composta por Grégoire, La Fayette, Mirabeau, Condorcet, Barnave. 
sociais dominantes na França e na Europa como a experimentada em situação de marginalização, discriminação ou preconceito favorável a alguma dominação "periférica", como a escravidão. Assim, Grégoire desenvolve um ideal cristão-republicano de incumbência e compromisso com os casos majoritários de injustiça, sem descuidar, de forma alguma, dos casos mais marginais ou mais inquestionáveis e distantes, mas que uma mesma fidelidade à dignidade do homem e à ação de redenção que Cristo ensinou a tratar de igual modo.

Sabemos que em meio aos estados despóticos só o cristianismo em suas assembleias religiosas reconhece a dignidade humana escondida detrás dos farrapos da miséria, e que pelo menos nas igrejas o pobre se encontra com seus iguais.

Sabemos que, em geral, os que implantaram as colônias foram pouco cuidadosos com a instrução cristã dos escravos porque temiam a influência de uma religião inimiga da servidão. A companhia de Serra Leoa, querendo abolir o tráfico de escravos e levar a civilização ao litoral da África, sentiu a necessidade de seguir uma direção oposta. E foi com a propagação do Evangelho que fundou o meio infalível para civilizar uma colônia de negros libertos. Também as últimas notícias de Caiena nos falam dos sacerdotes patriotas que, depois do decreto de 16 do pluvioso, ajudaram poderosamente a manter a ordem e a tranquilidade, uma vez que os negros se tomaram cidadãos. $^{10}$

Na véspera do discurso de Robespierre sobre os princípios de moral, a Convenção decretou a abolição da escravatura nas colônias (4-II-1794), comemorada com uma festa no decadi seguinte. Duzentos homens de cor e outros tantos brancos dirigiram-se ao então templo da Razão levando a Declaração dos Direitos Humanos. "O artigo que diz que homem algum pode se vender, nem ser vendido, recebeu fortes aclamações". Depois da cerimônia, realizada no templo da Razão, o cortejo dirigiu-se à casa de Franklin, onde foi dado um almoço. Vários protagonistas da festa pediram para serem enviados como missionários às colônias para fazer cumprir o decreto de abolição e levar a paz e a felicidade àquelas populações.

${ }^{10}$ Observations sur les calomniateurs et les persécuteurs en matière de Religion, Paris, 1796.
À tarde foi encenada uma versão teatral de Paul et Virginie e, no final da peça, foi lido o decreto, que suscitou os aplausos e a emoção dos presentes. Um baile fechou mais tarde a festa inspirada pelos jacobinos: "a Montanha viu-se honrada, distinguida por homens dignos de apreciar e defender a causa sagrada da Liberdade". ${ }^{11}$

Grégoire defende a Revolução sem exercer pressão alguma em detrimento do Estado que a Revolução institui. Nesse sentido, está mais próximo do Jacobinismo centralista e republicano, segundo a Constituição, do que das exigências menos comprometidas com o Estado dos cordeliers, enragés e outros que podiam, em nome do cristianismo (Fauchet e Roux), exigir uma justiça alienada da estrutura do Estado francês, segundo suas prioridades de defesa externa e de crédito ou confiança e intercâmbios econômicos e político-administrativos internos. Nesse sentido, é possível que Robespierre tivesse interpretado o compromisso de Grégoire como uma responsabilidade perante o modelo de Estado, segundo essas prioridades.

Grégoire deixa muito clara a sua oposição à contrarrevolução ${ }^{12}$, ao catolicismo fictício que a apoiava, a toda redução do poder constitucional, a toda negligência eclesiástica com relação à seriedade do compromisso com o Estado da Revolução, à imoralidade e à corrupção que o sistema político gera por si mesmo, e a toda tentativa de criar uma discórdia na relação entre a virtude cristã e o dever cívico.

A força do projeto de Grégoire fez com que tomasse uma assombrosa série de iniciativas que nenhum filósofo ou eclesiástico conseguiu superar, Justapondo questões tão importantes quanto distantes entre si, segundo as ocupações habituais da época. Grégoire preocupou-se com os escravos nas colônias, com os judeus na França, com os protestantes, com a Inquisição espanhola, com a centralização linguística e com o uso do francês nos ofícios religiosos, com a convivência dos cultos cívicos com os religiosos, com a história da igreja reformista, com a condição das mulheres em relação ao cristianismo, com a solidariedade e a organização entre os escritores e cientistas de todos os países, com a melhoria da agricultura, propondo várias medidas de capacitação para os agricultores e criadores de

\footnotetext{
${ }^{11}$ Recueil des Actes du Comité de Salut Public, suplemento ao t. VI, Paris, 1978.

${ }^{12}$ Grégoire foi alvo de duras críticas por parte dos monarquistas. Cf. Les Actes des Apôtres em 1792.
} 
gado, com a conservação dos monumentos e o cultivo das artes, com a educação em geral e com a missão dos bispos que, como ele, entendiam que o trabalho responsável do pastor de almas devia ser referendado pela soberania da nação. ${ }^{13}$

Frente a toda essa obra, eis a conclusão do abade Baradère, que assistiu aos últimos momentos de Grégoire: "M. Grégoire identificou-se de tal maneira com nossa regeneração política, e nela exerceu um papel tão nobre, que nenhuma página de nossa história contemporânea poderá esquecer a influência religiosa e política que este homem extraordinário exerceu em nosso edifício social". ${ }^{14}$

Apesar dos esforços dos servis da época, Grégoire morreu sem se retratar do julgamento cívico segundo a Constituição Civil do Clero, e sua morte foi lamentada do bispado de Blois às colônias, que dele se recordavam por sua nítida e corajosa postura frente à escravatura.

Ao que parece, o cortejo fúnebre de Grégoire reuniu cerca de 20.000 pessoas, em sua maioria operários e estudantes. Haiti e São Domingos se unem à cerimônia fúnebre do defensor dos negros com ofícios e homenagens. Grégoire deixa livros para Porto Príncipe e para a biblioteca do Arsenal, e muitas orações para seus inimigos "mortos e vivos". ${ }^{15}$

${ }^{13}$ Cf. todos os títulos compilados na edição das obras de Grégoire citada na primeira nota. Gazier diz a propósito da atuação de Grégoire no Comitê de Instrução Pública: "Foi no período mais forte do Terror que preparou, junto com seus colegas, os projetos de lei que deram à luz a Escola Politécnica, as Escolas Normais, o Conservatório de Artes e Ofícios, a Repartição de Longitudes, o Conservatório de Música, etc". Em Etudes sur l'histoire religieuse de la Révolution, Paris, 1887, p. 215.

${ }^{14}$ Abade Baradère, Derniers moments de M. Grégoire, ancien évêque de Blois, Paris, 1831, p. 5 .

${ }^{5}$ Cf. B. PLONGERON, Dictionnaire d'Histoire et de Géographie Ecclésiastiques, fasc. 126

\section{A justiça evangélica e o sentimento religioso na Revolução. Fauchet}

Apesar de mil esforços para penetrar nas causas das agitações dos estados, nota-se algo que nos escapa, um não sei quê, escondido não sei onde, e isto me parece ser a razão eficaz de todas as revoluções. Essa razão secreta é tanto mais inquietante por não poder ser percebida no homem da sociedade. Mas o homem da sociedade não começou sendo o homem da natureza? É, portanto, este que deve ser interrogado. Esse princípio desconhecido não nasceria de uma vaga inquietação, tão particular ao nosso coração, que nos faz menosprezar tanto a felicidade como a desgraça e nos lança de revolução em revolução até o último dos séculos? E essa inquietação, de onde procede? Não sei; talvez da consciência de outra vida, talvez de uma aspiração secreta à divindade. Seja qual for a sua origem, existe em todos os povos. Encontra-se entre os selvagens e em todas as nossas sociedades. Os maus costumes a tornam mais exigente e é devastadora de impérios. ${ }^{1}$

Essa ideia contém a máxima exigência religiosa ao espírito revolucionário. Chega a apresentar a divindade como ideal máximo da revolução, e esta chega a transcender a si mesma ao aspirar a alguma coisa que possa contradizer seu estado ou sua vida. $\mathrm{O}$ anelo revolucionário é, para o autor das linhas acima, Chateaubriand, um anelo de impossível realização nesta terra, uma distorção do espírito de perfeição que pertence à Religião. Assim, invertendo de certo modo a ideia que Ernst Bloch nos dará em pleno século XX, Chateaubriand considera normal, e sem outro objetivo, a grande esperança de uma nova vida dentro dos limites estritos da vivência religiosa. Talvez convenha dizer que Chateaubriand começou a Revolução Francesa na América e a terminou na Inglaterra, onde escreveu essas ideias sobre o caráter vão do esforço revolucionário no social, e sobre a religião como única realidade à qual pode pertencer o profundo impulso revolucionário.

Por outro lado, durante a Revolução Francesa foi consideravelmente reconhecida a necessidade de dotar de religiosidade a ação política e qualquer iniciativa de transformação social; de dotar de um espírito de

${ }^{1}$ CHATEAUBRIAND, F. R., Essai historique, politique et moral sur les Révolutions anciennes et modernes, Bruxelas, 1824 (1 ${ }^{\text {a }}$ ed. 1797), t. I, pp. 361-362. 
devoção, que a experiência histórica ocidental viveu através da religião, as manifestações da política considerada relevante. Wandelaincourt resume da seguinte maneira essa ideia, considerando o legado do iluminismo:

Os antigos sabiam muito bem que o amor à liberdade, puro e simples, não podia gerar o entusiasmo pelas grandes ações. Os romanos, diz Montesquieu, mesclavam um sentimento religioso ao amor que sentiam por sua pátria. Roma armava sua ambição de uma razão celeste e assim obtinha a vitória contra as potências mais temíveis... Os ateus estão confessando que sem a Religião não se pode nada ao afirmarem que todos os legisladores recorreram à intervenção do céu para que os povos, reconhecendo o mesmo poder na criação do homem e na das cidades, obedeçam com alegria e suportem docilmente o jugo das leis. ${ }^{2}$

Mas serão sacerdotes católicos os que levarão a argumentação teológica ao próprio coração da Revolução de forma positiva e entusiasta, sem complacência com os argumentos "maquiavélicos" dos ilustrados. Em suas "práticas cívicas" (1790-91), Lamourette, grão-vigário e membro da Academia de Arras, mais tarde bispo constitucional de Lyon, não se revela um "moderado" que a revolução do Terror destruiria com facilidade, como disseram os historiadores céticos da Revolução. Junto com Grégoire, defenderá abertamente a derrubada da monarquia com o apoio da Bíblia.

Nossos livros sagrados nos apresentam, em toda parte, o poder máximo sempre nas mãos dos reis, trazendo consigo o abalo da ordem como resultado da extinção da religião verdadeira, característica própria dos gentios. Quando os guias do povo de Deus queriam afirmá-lo no respeito de suas leis e no apreço de seu regime, ofereciam-lhe o contraste entre sua sabedoria, doçura e equanimidade, e o jugo que os reis das nações impunham aos outros homens. Já que esse vocábulo rei era tão usado pelos pagãos, os escritores sagrados não o empregavam jamais sem adscrever as misérias da idolatria... É por essa razão que quando a Escritura nos conta como os israelitas resolveram afinal mudar sua forma de

${ }^{2}$ WANDELAINCOURT, A. H. (bispo de Haute Marne), Réflexions philosophiques sur les systèmes des athées, des anti-chrétiens, des anti-prêtres, et sur celui de Réveillère-Lépeaux, Paris, 1797, p. 30.

Abade LAMOURETTE, Prones civiques ou le pasteur patriote, Paris, 1790-91, Prone I, p. 16: "La Révolution considérée à la lumière de la Religion". governo, dando-se um rei, objeta que nesse processo o povo de Deus quis assemelhar-se aos infiéis e afastar-se dos caminhos do Senhor. Esta passagem da história dos hebreus nos é narrada como a época do grande erro e como um engano que os tornaria mais viciosos infelizes para sempre. Escutai, irmãos, o que diz Samuel da parte do Eterno ao povo de Israel: "Eis o direito do rei que reinará sobre vós. Tomará vossos filhos e os destinará aos seus carros e cavalarias e os fará correr para a guerra na frente do seu carro. Empregá-los-á como chefes de mil e como chefes de cinquenta; fará com que cultivem suas terras, façam suas colheitas, e fabriquem suas armas de guerra e os arneses de seus carros. Tomará vossas filhas como perfumistas, cozinheiras e padeiras. Tomará o melhor de vossos campos, de vossas vinhas e de vossos olivais, para dá-los aos seus oficiais Cobrará o dízimo de vossas searas e de vossas vinhas e dará produto aos seus eunucos e aos seus oficiais. Tomará para os seus labores o melhor de vossos criados, de vossas criadas, de vossos bois, de vossos asnos. Cobrará o dízimo dos rebanhos e vós mesmos sereis convertidos em seus escravos". (Samuel, I, 8, 11-18). Foi portanto a partir dos gentios que a monarquia absoluta chegou até a religião verdadeira.

Volney partilha dessa ideia da monarquia absoluta como blasfêmia, de acordo com a história de Samuel. No entanto, sua conclusão é ambígua e perigosamente teocrática:

Se, entre os Judeus, o estabelecimento de uma realeza e de um rei foi, como diz o historiador, uma coisa contrária à vontade de Deus, daî não deriva diretamente que em lugar de ser de direito divino, a realeza não passa de uma invenção do homem, uma rebelião do homem contra Deus, e que o único governo santo e sagrado é o governo de Deus pelos sacerdotes, quer dizer, dos sacerdotes em nome de Deus?

Em sua segunda prática, Lamourette afirma que a revolução ajudará a prática das virtudes evangélicas. Não acredita numa descristianização como resultado da própria revolução, mas na recuperação de uma moral cristã mais pura.

${ }^{4}$ C.F. VOLNEY, Catéchisme du Citoyen Français, Paris, 1793, p. 464 
Também relaciona ${ }^{5}$ o aparecimento do cristianismo à abolição da escravatura:

Quando Jesus Cristo começou sua vida entre os homens, o poder dos césares exercia com frieza a sua força e a sua tirania para oprimir a terra. A ideia da nulidade dos povos e de seu destino, a serem submetidos ao jugo de todos os caprichos de um poder sem limites, confundira-se de tal maneira com a da necessidade invencível e imutável, que os que estavam sofrendo essa profunda servidão haviam perdido inclusive o desejo de escapar dela e que, há muito tempo, o silêncio do estupor e do embrutecimento havia sucedido ao clamor da antiga superioridade republicana... Imaginai, irmãos meus, a impressão que devia causar num povo, a quem a duração e o excesso da escravidão havia feito perder toda ideia e esperança de um estado menos humilhante e menos duro, a presença de um homem revestido de um caráter tão sublime, que lhes recorda os princípios da fraternidade e da igualdade, que ele mesmo observa com uma espécie de veneração... É necessário dar-se conta de que no início de seu ministério público, não encontra no povo um único inimigo de sua pessoa, nem um único detrator de sua doutrina, e que se depois esse mesmo povo, sempre essencialmente justo e bom pela própria natureza, serve ao ódio e à maldade de seus perseguidores, é porque ficou alienado pelas astúcias e calúnias dos chefes da sinagoga, quer dizer, enganado e seduzido pelo espírito de dominação e de aristocracia.

É uma curiosa coincidência que a acusação, aplicada aos líderes revolucionários, que impunham sua liderança de forma considerada pouco democrática, também fosse a de pretender ressuscitar a monarquia que eles representavam

Outro sacerdote aborda a temática da justiça social a partir de sua experiência pastoral e projetando a solução para a miséria no curso das instituições revolucionárias ${ }^{6}$ :

... À mercê de exações arbitrárias, os homens não ousam ser laboriosos. Os subsídios, os impostos e as leis fiscais esgotam sua triste existência, ultrapassando seu limite, e a miséria acaba sendo o

\footnotetext{
${ }^{5}$ Abade LAMOURETTE, op. cit., Prone III, p. 6.

${ }^{6}$ A. F. H. BEAUMEL, Discours patriotique prononcé par... Electeur, Curé de la Côte, district de Lodève à ses paroissiens, le 14 juillet, an II de la Liberté.
}

asilo para onde os conduz o desalento. Quanto mais trabalharmos, mais subjugados seremos, esta é a máxima desoladora e destrutiva dos campos... É necessário que vos conte o que vi quando entrei em vossas humildes cabanas para que aprendais a bendizer uma providência que em breve vos vingará desse desamparo civil; em seu domínio percebi a miséria, em toda parte a penúria e a necessidade, sob formas horrendas e repugnantes; contemplei uma pálida mãe, lívida, amparando com uma das mãos a uma criança coberta de farrapos e com a outra apertando contra o seu seio descarnado e infortunado que acabara de nascer; observei esse pai de família, oprimido pelas fadigas da jornada, fixando seus olhos semicerrados num lar sombrio e úmido: tornando a ver o que mais amava, o sorriso não aflorava em seus lábios, seus desditosos filhos embalados pelo pó, debatendo-se contra a fome. Em vão, em meio à natureza que também parece lançar contra eles os seus elementos destruidores, emitiam seus gemidos?! (Aqui o público estremeceu, chorou e as abóbadas sagradas do templo ressoaram com os gritos dolorosos que interrompiam o orador.)

Logo a divina Constituição se mostrará e, ao vê-la, a França se recuperará; a liberdade erguerá sua serena fronte; a licenciosidade e a tirania baixarão a cabeça tremendo. Esta obra-prima da inteligência elevará, sobre as ruínas dos abusos e da opressão, um edifício sublime, apoiado nas bases imutáveis da razão e da natureza, reclamando os direitos do gênero humano... Logo a Aristocracia será enterrada; a nova nobreza, sua cúmplice e sustentação, cairá numa merecida humilhação e não mais assolará nem devorará os habitantes do campo e da cidade ...

Como de costume naqueles tempos, o Te Deum arrematou esse discurso de aniversário da tomada da Bastilha ( $2^{\circ}$ ano).

A luta contra a tirania transformava-se na última obra da criação do mundo. Exclamava Bonneville ${ }^{7}$ ao fazer a apologia da luta universal contra a tirania: "Um Deus ainda avança para terminar a criação".

É preciso levar em conta o fato de a Revolução Francesa ser considerada uma mudança sublime no destino da humanidade e uma ação da própria providência divina, sem que tal ideia fosse simples

${ }^{7}$ BONNEVILLE, N., De l'Esprit des Religions, Paris, 1792 (nova edição), 2 v., p. 434. 
grandiloquência ou retórica da qual tivesse se apropriado a política da Revolução. Embora as imitações pudessem merecer essa avaliação, a ideia original que desencadeara essa linguagem pertencia a uma filosofia da história. Essa última atribuía duas causas principais à Revolução: o uso da imprensa a serviço da consciência revolucionária e o das artes da navegação a serviço da comunicação entre povos livres e entre povos que lutam por sua liberdade.

Dessa maneira, na opinião de vários filósofos, a imprensa e a bússola foram ao mesmo tempo instrumentos de causas materiais e difusas da Revolução Francesa, voltadas para uma mesma orientação do progresso moral e material, representando as suas diretrizes como revolução ideológica e internacional, racional e comunicativa.

Claude Fauchet revelou-se devido a sua participação na tomada da Bastilha e ao sermão que pronunciou depois, quando a Igreja Católica festejou o acontecimento. Em cinco de agosto, Fauchet pronunciou seu sermão no serviço fúnebre pelos heróis da Bastilha em Saint-Jacquesl'Hôpital. Haviam transcorrido vinte dias desde a tomada da Bastilha. A igreja oferecia um cenário austero e solene, com tecidos cobrindo os altares laterais e um grande Cristo Crucificado pendendo do teto no cruzeiro do templo ${ }^{8}$ :

O tom de seu discurso foi novo, assim como o tema e a ocasião: era o grito de júbilo da liberdade triunfante; era a promulgação de suas máximas em nome da religião e na cátedra da verdade ${ }^{9}$; era a história dos crimes do despotismo, assombrado ao ver-se atacado por um sacerdote, e mais assombrado ainda ao ver se voltarem contra a tirania as armas que até então ela havia utilizado com ousadia, as armas do próprio cristianismo e da Bíblia. Sabemos a vantagem que a tirania havia tirado destas palavras, Dai a César o que é de César.

Sim, exclama o orador: mas e o que não é dele, também lhe deve ser

${ }^{8}$ Vários, Collection Complète des Tableaux Historiques de la Révolution Française, Paris, 1804 , t. I, p. 86.

${ }^{9}$ Fauchet encarna, como sacerdote e como militante, a nova liberdade da Igreja que se alinha do lado dos oprimidos e chega a capitanear o curso ideológico da própria liberdade como consequência natural do sacerdócio. A autoridade que conquistou um setor importante da Comuna de Paris fez com que - com excesso de consideração para com práticas filantrópicas da Igreja do Antigo Regime - lhe fosse oferecido o cargo, criado para ele, de "esmoler maior" da Comuna. Cf. BAILL Y, J. S., Mémoires, Paris, 1821. entregue? Pois a liberdade não é de forma alguma de César, é da natureza humana. $\mathrm{O}$ direito de oprimir não é de forma alguma de César, e o direito de defender-se é de todos os homens. Os tributos não pertencem ao príncipe se o povo não consentir: os reis não têm direitos na sociedade além dos concedidos pelas leis, e nada é deles a não ser por vontade pública. Esta é a verdadeira voz de Deus. O orador acusa de impiedade os falsos doutores que perverteram o sentido de muitas passagens das sagradas escrituras. Quanto mal não fizeram ao mundo os falsos intérpretes dos oráculos divinos quando pretenderam, em nome do céu, que o povo fosse abatido sob as vontades arbitrárias dos chefes! Foram eles que consagraram o despotismo, transformando Deus em cúmplice dos tiranos; trata-se do maior crime de todos.

Fauchet combate esses falsos doutores com outras passagens da escritura, mais convincentes e vitoriosas. Ele afirma que nem para merecer o crédito da filosofia, a Revolução Francesa deixa de estar ordenada pela religião e pelos planos da Providência. Não hesita em prestar a essa filosofia, tão caluniada até então, a homenagem que lhe é devida. "É preciso dizer, e bem alto, até nos templos:

Foi a filosofia que ressuscitou a natureza; foi ela que recriou o espírito humano e devolveu um coração à sociedade. A humanidade perecera por causa da servidão, foi reanimada pelo pensamento. Procurando em si mesma, encontrou a liberdade. Filósofos, haveis pensado; nós vos agradecemos. Representantes da pátria, vós nos destes mais valor; nós vos bendizemos. Cidadãos de Paris, irmãos generosos, arvorastes o estandarte da liberdade; glória a vós! Também vós, vítimas intrépidas que vos entregastes à felicidade da pátria, recebei nos céus, junto com nossas agradecidas lágrimas, e alegria de vossa vitória!...

Pode-se avaliar o efeito deste discurso sobre um público dominado pelas mesmas paixões, pelo mesmo espírito que o orador. Sua cabeça foi espontaneamente coberta por uma coroa cívica, fruto do entusiasmo dos ouvintes que aplaudiram ao seu redor: um arauto a levou em suas mãos precedendo o abade Fauchet em sua caminhada até a prefeitura, aonde chegou rodeado por todos os funcionários do distrito, entre duas companhias que marchavam ao som do tambor e com bandeiras desfraldadas. Imagem da pompa e do cortejo que, mais de uma vez nos 
países livres e antigos, atestavam ou recompensavam o triunfo ou os serviços da eloquência.

Era um momento muito significativo na história de nossos costumes: o momento em que o elogio público, até então reservado aos cargos, aos nomes, às posições ou ao nascimento, fora concedido a vítimas desconhecidas, a homens obscuros, a maioria dos quais trajado ou mal coberto pelas librés da indigência. Isso significava arrancar o orgulho dos que se acreditavam investidos dos privilégios mais exclusivos; era adiantarse à igualdade de direitos que seria decretada ao povo francês pouco depois. $^{10}$

A religião, o cristianismo, encabeçava assim a força revolucionária e sua comemoração ${ }^{11}$ :

Predizia-se, anunciava-se que a religião... renasceria triunfante e purificada; e este era um dos benefícios da revolução. Fora preparada mediante princípios consagrados pelo evangelho, pelas máximas de igualdade e fraternidade que a opinião pública pedia como bases da Constituição que a Assembleia Nacional elaboraria. Essa igualdade, essa fraternidade, tão frequentemente recomendadas no evangelho, constituíam a característica principal do cristão primitivo; a revolução nos reconduzia a elas. Tais eram as máximas pronunciadas então dos púlpitos pelos sacerdotes. Muitos deles seguiram fielmente seus princípios, enquanto outros, que inicialmente os pregavam, mais adiante os combateram com outros textos da escritura, depois de os representantes do povo terem declarado como bens nacionais os bens da Igreja, quer dizer, os do clero, já que há muito tempo o clero acreditava ser a Igreja, assim como a nobreza acreditava ser a nação.

Ao renunciar aos dízimos, o bispo de Paris declarava:

entregamos todos os dízimos eclesiásticos nas mãos de uma nação justa e generosa: que o Evangelho seja anunciado; que o culto divino seja celebrado com decência e dignidade; que as igrejas sejam providas de pastores virtuosos e diligentes; que os pobres do povo sejam socorridos, eis o destino de nossos dízimos! eis a finalidade de

\footnotetext{
${ }^{10}$ Tableaux, op. cit., t. I, p. 87.
}

${ }^{11} I d .$, p. 88 nosso ministério e de nossos votos! Nós confiamos na Assembleia Nacional... ${ }^{12}$

Fauchet $^{13}$ já em 1789 tornava públicas as suas ideias sobre uma "religião nacional", ideias discutidas, como vimos, por outros sacerdotes católicos partidários da Revolução, porém na sua primeira fase, antes da Convenção.

... dai, pois, a César o que dele tendes; mas não esqueçais de dar a Deus o que lhe deveis. Teólogos, é tão difícil compreender isto? Essa linguagem cheia de sentido poderia significar outra coisa, a não ser o fato de que os judeus tinham que suportar seu jugo, já que o sofriam sem reclamar nada, e que também deviam ter lembrado as leis antigas de sua nação e os direitos de Deus, que os teriam preservado da escravidão se tivessem sabido ser fiéis aos deveres básicos da cidadania? ${ }^{14}$ Cristo predisse que seriam covardes até o término fatal; que não saberiam reclamar sabiamente e em conjunto seus direitos naturais e nacionais; que, portanto, sua rebelião seria insensata e sanguinária; que a discórdia reinaria inclusive em seus esforços para rejeitar o jugo que antes haviam admitido; que seu estado seria derrubado, assolado sem poder se recuperar, e Cristo chorou a ruína dessa pátria ingrata que, ademais, faria dele uma vítima.

A doutrina dos apóstolos, sua conduta e a de todos os mártires do Evangelho, foi sempre conforme a estes princípios. Resistiram até a morte às ordens injustas dos tiranos. Obedeceram a tudo que não acharam iníquo; não acataram jamais a injustiça dos príncipes.

Sábios doutores, relede S. Atanásio, S. Basílio, S. Gregório nacianceno, Sto. Hilário de Poitiers e vede se os tiranos Constâncio, Valério, Juliano, Constância se impuseram a eles. Examinai a conduta de Ambrósio em relação a Teodósio, de Léger para com Thierry, de Thomas de Canterbury para com Henrique II. Embora os filósofos digam que esses grandes homens, esses santos, eram rebeldes fanáticos, o senso comum, o valor, dizem que são os filósofos, aduladores dos tiranos, ${ }^{15}$ os mais covardes, os piores cidadãos.

\footnotetext{
${ }^{12}$ BAILLY, op. cit.

${ }^{13}$ FAUCHET, Cl, De la Religion Nationale, Paris, 1789, p. 69.

${ }^{14} \mathrm{Cf}$. o que Lamennais diz a respeito da Polônia e da Irlanda e que citaremos mais adiante.

${ }^{15}$ Alusão às relações de filósofos como Voltaire ou Diderot com os monarcas.
} 
A religião católica portanto autoriza todas as sábias resistências às invasões de propriedades por parte da tirania, aos atentados contra o direito natural e social; longe de opor-se às reformas que podem devolver a justiça ao governo, as exige e as apóia: não deseja outra coisa além da sabedoria, da concórdia e da felicidade do Universo.

Fauchet conjuga os direitos humanos ao espírito cristão de fraternidade. Faz da fraternidade universal uma característica regeneradora de todo povo, traço ensinado pelo Evangelho. O novo mandamento de Cristo é a base para resistir às afrontas da tirania e para implantar a nova sociedade. "... Claude Fauchet é o mesmo em qualquer lugar, porque sabe fazer a religião ser amada (fraternidade) ao saber estabelecê-la sobre os direitos inalienáveis do homem". ${ }^{16}$

Fauchet define sem hesitações o condicionamento da sociedade pela moral cristã ${ }^{17}$ :

As leis civis não podem jamais criar a moral; devem segui-la e prescrevê-la. Tendes como primeira de vossas leis, que é a base de todas as demais, uma Religião: graças ao Céu, esta Religião é a única verdadeira, a única perfeita e, devido ao mandamento de fraternidade geral que recebeu do pai universal, deve chegar a ser um dia a religião de todo o gênero humano; é necessário que toda a legislação seja adequada a ela, caso contrário ficareis em contradição convosco mesmos, e vosso governo permanecerá no caos de sempre por falta de concordância entre as leis de Deus e as dos homens. A doutrina sobre a usura, os contratos, sobre todas as relações sociais que passam pela moral, assim como ocorre com o dogma e com os sacramentos, pertence unicamente à Igreja. É preciso repetir: a opinião contrária que quer atrapalhar esse ensinamento com a autoridade legislativa e oposta dos príncipes é absurda, é ímpia.

Pelo mesmo motivo, Fauchet defende a independência material da Igreja, acarretando o respeito às suas propriedades, embora proponha ${ }^{18}$ que

Fauchet quer dar a entender que a teologia política cristã é mais comprometida com a justiça social do que a filosofia política do Iluminismo.

${ }^{16}$ La Bouche de fer, $\mathrm{n}^{\circ}$ 12, 27-I-1791.

${ }^{17}$ FAUCHET, Cl., op. cit., p. 82

${ }^{18} I d .$, p. 145. as ordens contemplativas se dediquem "à educação dos cidadãos e ao cultivo dos altos estudos".

Tolera os cultos não-católicos, desde que se manifestem privadamente. A conclusão é de que a religião católica é a única nacional, pelo fato de possuir de forma mais institucionalizada a missão evangélica do mandato divino: "Amai-vos uns aos outros..."

Fauchet e Bonneville fizeram uma loja maçônica que se reunia numa sala do Palais-Royal se transformar num clube, com o nome de Círculo Social" ${ }^{19}$. Vários deles "continuaram como representantes da francomaçonaria cujos ritos, segundo eles mesmos, deveriam solucionar os problemas da Revolução Francesa; outros, como Fauchet, tentaram arrebatar a multidão em nome do Evangelho, luz que, diziam eles, fora sequestrada pelos teólogos durante mil e oitocentos anos e agora, graças à Revolução, brilharia para sempre diante de todo mundo".

O papel de Fauchet revelou-se difícil e, para alguns, ambíguo, além de pernicioso, segundo os que o condenaram:

Fauchet, bispo de Calvados, conhecido por seu zelo entusiasta no começo da Revolução, e por seu sucesso na tribuna do Palais-Royal (então chamada de tribuna da Bouche-de-fer ${ }^{20}$ ), homem de quem era fácil zombar devido a sua ambição patriarcal e ao misticismo que pretendera introduzir nos princípios patrióticos, mas cuja humanidade, patriotismo e sabedoria eram dignos de respeito. ${ }^{21}$

Fauchet desenvolveu especialmente sua ideia de cristianismo revolucionário na abertura da "Confederação universal de amigos da verdade", organizada pelo Círculo Social ${ }^{22}$ :

As leis gerais. esqueceram a amizade que associa tudo, para ocuparem-se apenas da discórdia que tudo divide. Até agora

${ }^{19}$ BLANC, Louis, Histoire de la Révolution Française, Paris, 1866, p. 192.

${ }^{20}$ Os homens de La Bouche de fer - Fauchet, Bonneville e Paine - criaram uma "Confederação universal de amigos da verdade" para transmitir sua religião fraterna e universal. Paine (Payne) e Cloots logo foram declarados cidadãos franceses em virtude do decreto que concedia esse título a todos os estrangeiros que tinham escrito ou combatido pela liberdade e a igualdade. Cf. Tableaux, p. 67e.

${ }^{21}$ Tableaux, p. 362.

${ }^{22}$ La Bouche de fer, $\mathrm{n}^{\circ}$ 3, outubro de 1790, pp. 18-26 e segs. 
nenhuma lei tomou por base social o homem como um ser que ama. Nenhuma direcionou as instituições públicas para essa inclinação conciliadora: o pressuposto de todas as leis foi, pelo contrário, o homem egoísta e adversário de seu semelhante. Por conseguinte, todas elas só trataram de proibir, isolar os interesses, privilegiar, garantir individualmente, conceder o desfrute a uns e a repressão a outros, conceder funções a minorias seletas, manter na passividade a multidão, dotar com superabundância os palácios e com escassez os casebres. As leis proibiram a humanidade aos ricos, protegendo suas insolentes delícias; despojaram os pobres dos direitos da natureza, sufocando até suas mínimas queixas; ergueram obstáculos ao gênio, cortaram as asas do pensar, encarceraram o coração humano.

As religiões não foram melhores do que as leis. Mas o cristianismo pode ser a religião verdadeira da humanidade, se sua exigência de justiça se manifestar como consequência do reconhecimento e da vivência do amor, da caridade evangélica, depósito precioso da divindade na terra. Assim, a fidelidade à manifestação mais sublime e evangélica da divindade, o amor, constitui a base da "teologia da libertação" de Fauchet.

As religiões que, por sua essência, deviam, em nome do céu, reunir os homens, por causa de sua rigidez, de sua intolerância e através da escravização do pensamento, os desuniram ainda mais. Tamanha foi a desordem do que se chamava de ordem social, que os elementos da religião - depositados na natureza humana e que, combinados com os elementos do amor que também ali estão, deveriam tê-lo reforçado, propagando a virtude e promovendo a felicidade do universo - foram divididos, dissociados e postos em contradição de tal maneira que provocaram a desdita do mundo e o tormento das consciências.

Só pode haver uma religião verdadeira, aquela que disse aos homens: "Amai-vos uns aos outros", e que proporciona, para cumprir esse único dever, os meios mais doces e os motivos mais poderosos. Essa religião existe. É eterna como a lei do amor: os homens, desunidos pelas leis da discórdia que regiam os impérios, a desconheceram. É preciso ensiná-la em sua casta nudez, em sua pura verdade; e todo o gênero humano, enamorado de sua divina beleza, formará um só coração para adorá-la.

Fauchet viu nas lojas maçônicas o protótipo da associação dessa nova Igreja purificada. Entretanto, lamenta-se de que estas também tenham reproduzido em seu interior as hierarquias, as hipocrisias, os servilismos e as distinções da ordem social. Contudo, ele considera que as lojas se aproximam mais das qualidades da Igreja primitiva do que as instituições católicas da época, ainda mais corrompidas:

Essa imperfeição e essa discordância nas próprias Sociedades consagradas à amizade e à união eram inevitáveis... Os homens cujas prerrogativas de riqueza ou de situação nas classes nacionais transformaram em soberbos e despóticos continuariam a sê-lo nas lojas maçônicas, e os que a degradação de sua posição e fortuna tomava submissos e baixos jamais podiam alçar-se a toda a altura do homem em suas comunicações associativas. Vive-se muito com os governos imorais, e muito pouco com as Sociedades de amizade. Isto faz com que os primeiros influenciem e modifiquem bastante mais as coisas que as segundas... No entanto, as sociedades antigas que se perpetuaram até nossos dias com os princípios de fraqueza, igualdade, liberdade, fraternidade, amizade, concórdia e união, embora não tenham podido triunfar sobre as influências dos governos que depravam os homens, pelo menos conservaram esse fogo sagrado da natureza social, essa chama elementar do amor que une e que deveria servir, em qualquer época, para recriar o gênero humano. Essas sociedades vestais têm os primeiros direitos para entrar na Confederação universal dos amigos da verdade...

Da América à França, dos primeiros apóstolos à Revolução Francesa, da França a Paris, e de Paris ao mundo inteiro, "querer é tudo"23.

A América dera o exemplo à Europa, a França dá o exemplo ao universo. Somos livres, irreversivelmente; o gênero humano o será, já que o gênio francês, elevado à altura da liberdade, não pode mais ser contido, em breve a mostrará com tudo que tem de atraente e fará com que os dois mundos a venerem... Querer é tudo. Doze homens quiseram, derrubaram os templos e aniquilaram todas as religiões das nações então conhecidas: estavam animados por uma força divina, é verdade; mas esta força divina ocupava a plenitude e a aquiescência de suas vontades. Faltará esta força aos que tomarão a firme e consciente decisão de unir o gênero humano com esse evangelho

\footnotetext{
${ }^{23} I d .$, pp. 26,28 e 29.
} 
eterno do amor que é a religião da felicidade? ${ }^{24}$ Queiramos, e assim acreditemos e salvemos o universo..

Não testemunhamos como essas Sociedades, todas elas formadas através da eleição do povo, dos primeiros Eleitores e dos representantes das Comunas, essas associações cívicas de amigos da Constituição, de amigos da liberdade de Imprensa, esses clubes fraternos que se aliaram em todos os lugares para a liberdade, formaram a opinião pública de uma maneira irresistível e dominaram o Império?...

Pode-se dizer que, ironicamente, Fauchet vê na sociabilidade maçônica o potencial revolucionário para a instauração de um cristianismo verdadeiro, ao passo que Barruel atribuirá à maçonaria a conspiração mais descristianizadora da Revolução.

Embora se atribua a Fauchet a posse de direito da loja maçônica que em seguida se dividiu dando lugar em parte ao Círculo Social, ele diz que, como não gostava do mistério ou do segredo em tomo das verdades, não quis fazer parte da maçonaria.

Em posição diametralmente oposta à recriação do catolicismo por De Maistre, Fauchet insiste nos aspectos da Revolução que sintonizam com a caridade universal, não com a destruição e o castigo:

Como a França se ocupa dos grandes projetos de regeneração da ordem social, sendo Paris o centro deste novo movimento que tende a vivificar os homens, é justamente na França que se encontra de fato o foco do amor à humanidade. Seus eflúvios chegam de todo o reino à capital, só é preciso recebê-los para que a correspondência entre todos os amigos ardorosos da verdade seja facilmente estabelecida. Mas, para estendê-la a toda a terra, a dificuldade parece maior. Em todos os lugares já existem esses homens, guardiães francos dos princípios da igualdade e da fraternidade; estão por toda parte reunidos em associações de amizade: aqui reside o núcleo do gênero humano... Os círculos maçônicos se transformarão em cada cidade, em cada cantão, no centro em tomo do qual se formarão os círculos

${ }^{24} \mathrm{O}$ entusiasmo faria Fauchet dizer num desses sermões: "Irmãos, juremos no primeiro templo do império (Notre-Dame), sob esse imenso pavilhão cheio de estandartes consagrados à religião pela liberdade, juremos que seremos felizes"; BLANC, Louis, op. cit., p.91. mais numerosos de associados à grande Confederação de amigos da verdade...

Que a Religião não seja senão amor universal; que não apenas em seus dogmas e preceitos nada se interponha nem rompa esse vínculo sagrado, mas que também em seus ritos e usos nada freie nem debilite essa delicada harmonia dos corações; que o governo não seja senão uma lei de união geral; que não apenas na organização dos poderes constituídos para o bem de todos e na execução da vontade comum nada contradiga ou atenue esse direito de associação, como também que na educação pública e nos novos hábitos nacionais, nada lime nem afrouxe essa corrente de fraternidade; e na terra só haverá virtude e felicidade.

Depois de evocar uma vez mais os benefícios da sociabilidade desenvolvida pelas lojas maçônicas, Fauchet volta ao fundamento de sua teologia moral e revolucionária, o mandato evangélico ${ }^{25}$ :

... a verdadeira religião feita para o gênero humano; o que é, senhores? Não falo como sacerdote, falo como homem, e digo: o evangelho. Atribui tudo ao amor. Diviniza este sentimento reduzindo-o à igualdade, à unidade entre Deus e toda a família humana, sem exceção. É a única religião do mundo inteiro que tem esta base tão absoluta. É, pois, a única que merece ser considerada em nosso princípio de união e afeto geral. Todas as demais são excludentes, odiosas, estranhas a nossos projetos de concórdia plena e negam a verdadeira felicidade dos homens. Se, depois de examinarmos a questão, concluirmos que o evangelho é, de fato, o código religioso que o amor universal exige, e que guia os corações com os mais doces e poderosos motivos para que se entreguem sem reservas, ele será por essa razão a religião do gênero humano. A partir daí nos será fácil derrubar com um sopro o onipotente edifício bárbaro do ódio, da servidão e da discórdia erguido pelos teólogos sobre a mesma base divina do amor, da liberdade e da união. A filosofia já se antecipou no julgamento, já se pronunciou com evidência irresistível sobre os déspotas das consciências, os artífices da tirania e os incendiários das nações. É preciso conseguir, custe o que custar, que a religião seja só amor. E se o evangelho excluísse um único homem desse amor, seria necessário reformá-lo, pois terse-la infiltrado um erro contraditório entre os seus princípios. Foram

${ }^{25}$ La Bouche de fer, $\mathrm{n}^{\circ} 4$, outubro de 1790, p. 117 
precisamente os homens que falsearam essa norma santa, senão no texto, na interpretação, foram eles que impediram o evangelho de conquistar o universo inteiro.

Perdoai, senhores, se quando devo examinar uma questão com a dúvida metódica do filósofo, mesclo a um discurso feito em nome dos amigos do gênero humano uma afirmação que pode parecer prematura acerca da verdade fundamental do Evangelho. Minha própria convicção, que não posso trair, só a mim obriga e deixa a todos os demais o direito à discussão e à imparcialidade. Porém, quero assegurar de antemão que o evangelho bem entendido, fiel a si mesmo, convém a todos os espíritos porque os une, é feito para todos os corações porque os enlaça, é a religião universal integral porque vincula todo o gênero humano à unidade de um Deus amigo dos homens. Por fim, senhores, considero fácil demonstrar, contra todos os sacerdotes fanáticos, contra todos os teólogos odiosos, contra todos os devotos mal-humorados, que o evangelho não é senão tolerância e afeto, boa esperança, misericórdia, fraternidade, amor em suma, amor imenso, amor infinito, que abrange o céu e a terra, todos os seres e todos os tempos.

Fauchet repetia incansavelmente essa ideia. A Anacharsis Cloots ${ }^{26} \mathrm{o}$ "orador do gênero humano", que defendia um humanismo universalista, replicava: "Quanto à religião, senhor, julgo-a essencial para o gênero humano, e minha convicção é absoluta. Mas que religião? A que faz amar a todos os homens, aproxima-os de todos e, valendo-se dos motivos mais suaves, insta-os a fazerem-se mutuamente felizes. Isto eu encontro no evangelho e em nenhum outro lugar... O evangelho é, conforme digo, a perfeição da lei natural, e apenas isto".

Fauchet considera o amor que se traduz numa sociabilidade feliz uma faculdade inata do homem. Por isto elogia mas também critica Rousseau, pois este ${ }^{27}$ "diz que a sociedade familiar é a única natural e que deixa de sêlo quando o rebento já é forte e pode se emancipar; a partir daí, segundo ele, o homem não se acha mais vinculado aos demais homens por intermédio da natureza, mas de convenções.

${ }^{26}$ Id., Carta de Fauchet a Cloots, 18-X-1790.

${ }^{27} I d ., \mathrm{n}^{\mathrm{o}} 11,1790$, p. 173
Esse princípio, senhores, é absolutamente falso. O homem nunca interrompe a relação que, através de vínculos naturais, tem com os seus semelhantes. São estes laços universais da natureza que constituem as verdadeiras relações da sociedade... O homem tem necessidade de amar; esta necessidade está sempre presente, é a vontade permanente da natureza; assim, amor e sociedade são uma mesma coisa!". Mercier e Restif de la Bretonne concordarão com essa apreciação: a sociabilidade é natural e depende do amor (Restif abordará especialmente a sexualidade como fundamento da sociabilidade $)^{28}$ :

Quando o homem nasce, existe em sociedade consigo mesmo... Em virtude de seu amor-próprio, o homem quer ser o mais feliz que puder, não impõe limites a sua felicidade e essa é a essência do amor Sozinho não tem forças; pede ajuda, reconhece a ajuda, ama, é amado, é feliz...

Neste contexto - de naturalidade da instituição familiar, de confusão entre o amor e a sociabilidade e dos primeiros alicerces dos motivos sociais na sexualidade - deve-se situar a defesa do matrimônio dos sacerdotes. A perfeição moral dos ministros do culto católico seria melhor atingida através de seu estado matrimonial, já que este os dotaria de uma sociabilidade mais interdependente e responsável:

A Igreja Católica, cuja autoridade respeito, professa uma moral severa e quer assim distinguir-se de outras confissões; mas por que mostrar tanta severidade na especulação e não observar na prática senão o simulacro? Preferiria ter menos severidade na moral, mas poder manter uma conduta conforme a meus princípios. Preferiria contrair um laço legítimo, um laço consagrado pelo autor da natureza, e não arrastar cadeias que causassem vergonha.

Sim, repito, a maioria dos sacerdotes é de prevaricadores em seu estado por culpa da lei do celibato. Quantos deles vemos que reúnem todas as qualidades sociais, que a um bom coração somam grande honestidade e retidão, e que sofrem com grande dor por todas essas qualidades ficarem empanadas por nossos preconceitos relativos à incontinência! Não é algo realmente infeliz perder todo o valor das virtudes e das boas ações desses ministros por eles não poderem resistir a uma inclinação que os domina? Não é uma desgraça ver-se

\footnotetext{
${ }^{28} I d .$, p. 179
} 
atado para sempre a uma obrigação adquirida numa idade em que falta experiência, não se conhece os perigos da sedução e ainda não se sente todo o império das paixões? Ah, a religião não foi criada para atormentar as consciências, nem para tornar as pessoas infelizes.

Um sacerdote que fosse um modelo de virtudes conjugais, que possuísse com eminência especial as qualidades sociais, que soubesse aliar os deveres da vida civil às funções sagradas do ministério seria mais proveitoso e fecundo do que nossos sacerdotes celibatários. Sua vida seria menos ociosa, menos dissipada. Não se veria forçado a entregar-se a paixões que degradam o homem, a desordens que, como são feitas às escondidas, revestem-se de criminalidade. Ao contrário, sempre ocupado, sempre dedicado a trabalhos, o sacerdote infundiria conhecimentos úteis e virtuosos. A necessidade de manter uma mulher e filhos num estado decente seria um poderoso estímulo para ele. Renasceria a emulação entre o clero e com ela o gosto pelo estudo e pelas letras.

Os costumes têm muita influência sobre a religião. E sacerdotes decentes e moderados, sábios e experientes, a fariam florescer. $\mathrm{O}$ povo teria mais confiança em seus ministros. $\mathrm{O}$ culto seria mais respeitado; a religião melhor observada. Tomando-nos mais virtuosos, essa religião também daria mais energia ao caráter nacional, mais fibra ao patriotismo. Sendo menos frívolos, seríamos mais cidadãos...

Apesar da crítica que faz a Rousseau, Fauchet também defende as máximas do homem da natureza e da liberdade ${ }^{30}$ : "Existência para si, amor, sociabilidade, liberdade, estas quatro palavras contêm a série de direitos do homem, em pleno acordo com sua natureza". Da mesma forma, destaca a consciência que Rousseau possuía do sistema social, da "força das coisas" e de sua maneira de enfrentá-los:

\footnotetext{
${ }^{29}$ Moyens de rendre le clergé citoyen, ou le mariage des prêtres, s.l., s.d.

${ }^{30} \mathrm{O}$ abade Raynal já defendera uma teoria da sociedade sempre constituída pela vontade e pela natureza do homem, podendo ocorrer a liberdade no seio da civilização: "É portanto o estado de sociedade que, longe de ter que fazer do homem um escravo como pretenderam tantos filósofos, tornou-o, pelo contrário, livre; já que, através da sociedade, o mais forte teve a sua capacidade de causar danos reduzida". Lettre de l'abbé Raynal à l'assemblée nationale, Marselha, 10-XII-1789; Ibid., p. 182
}

Eis aqui suas imortais palavras (Rousseau: Contrato Social): “A finalidade de todos os sistemas de legislação se resume nestes dois objetivos principais: a liberdade e a igualdade. A liberdade, porque qualquer dependência particular corresponde a outro tanto de força tomada ao corpo do Estado, e a igualdade, porque a liberdade não pode subsistir sem ela. Já expliquei o que é a liberdade civil: (Rousseau disse que consistia em submeter-se unicamente à vontade geral, às leis que a expressam e sob as quais votou-se nominalmente). No que tange à igualdade", acrescenta Rousseau, "não se deve entender por essa palavra que os graus de poder e de riqueza sejam absolutamente os mesmos para todos, e sim que, quanto ao poder, seja exercido em virtude do posto e das leis, distanciado de qualquer violência, e quanto à riqueza, que nenhum cidadão chegue a ser tão opulento que possa comprar um outro, e ninguém seja tão pobre que procure se vender. Quereis dar consistência ao Estado? Aproximai ao máximo os pontos extremos; não aceiteis nem a opulência nem a miséria; estes dois estados, inseparáveis por natureza, são igualmente funestos para o bem comum; de um surgem os artífices da tirania e do outro, os tiranos. São sempre eles que traficam com a liberdade; um a compra, o outro a vende". Após essas verdades profundas e sensíveis, que contêm em alto grau toda regra de legislação, Rousseau coloca a dificuldade de estabelecer essa igualdade legal na prática. Responde decisivamente: "É precisamente pelo fato de a força das coisas tender sempre a destruir a igualdade que a força da legislação deve sempre tender a mantê-la". Uma vez dito isto, senhores, está tudo dito ...

Fauchet, no entanto, não concorda com as discriminações feitas por Rousseau aos países, quando este avalia o alcance das reformas específicas para aceder a uma maior liberdade política. ${ }^{31}$

Era lógico que a linha de pensamento de Fauchet convidasse ao pacifismo, condenasse a escravidão, ${ }^{32}$ apostasse em Condorcet $^{33} \mathrm{e}$ mostrasse, de maneira geral, um interesse pelas vanguardas sociais da

\footnotetext{
${ }^{31}$ La Bouche de fer, $\mathrm{n}^{\circ}$ 19, 19-II-1791, p. 296.

${ }^{32} I d ., \mathrm{n}^{\circ} 13, \mathrm{n}^{\circ} 15,1790$.
}

${ }^{33} I d ., \mathrm{n}^{\circ} 83,5-\mathrm{VII}-1791$. 
Revolução. Eis como Fauchet discorre sobre uma reforma agrária na França à luz do Evangelho ${ }^{34}$ :

"Um dos equívocos mais graves cometidos pelos economistas consiste em crer que as pequenas propriedades são menos úteis em geral e menos produtivas do que as grandes..." Depois dessa afirmação, Fauchet critica o descuido observado nas grandes propriedades, comparando-o ao capricho dos pequenos lotes e propriedades. Prossegue:

Se me perguntassem que relação há entre a Religião Nacional e essa aparente digressão sobre as pequenas propriedades e sobre a melhor formulação de uma lei agrária, eu lhes explicaria com a clareza da evidência, que julgam apreciar mas que raras vezes discerniram e trataram antes de obscurecer em suas obras. O Evangelho diz: 'Infelizes os ricos.' Os Economistas dizem: 'Bem-aventurados os ricos.' Sua doutrina nesse ponto apresenta uma contradição absoluta com a da religião. Tive, pois, de erguer-me contra as suas afirmações, que tendem a favorecer cada vez mais a extrema opulência de algumas fannlias e deixar que todo o território do reino seja invadido pela ordem dos grandes proprietários que, vendo-se donos de todas as fortunas, seriam, por uma consequência infalível, os tiranos da França inteira e inclusive do Rei ...

Fauchet inclinava-se por uma lei agrária que distribuísse mais os lotes, e também as propriedades, abolindo a primogenitura nas grandes propriedades.

Fauchet logo é atacado com os epítetos jacobinos de "impiedade" e "anarquia" por abordar evangelicamente a questão social, aprofundando-a política, filosófica e teologicamente, chegando a considerações mais ousadas que as dos prelados constitucionais e muitos de seus sacerdotes, mas sem o radicalismo de Roux. No entanto, Fauchet é acusado por Cloots (que um ano e meio depois seria acusado por Robespierre na linha da subversão favorável aos inimigos externos da França) de favorecer um projeto de lei agrária. ${ }^{35}$ Fauchetresponde assim:

${ }^{34}$ FAUCHET, CL, op. cit., p. 226.

${ }^{35}$ La Bouche de fer, $\mathrm{n}^{\circ}$ 28, 9-III-1791. Sobre as acusações e a condenação de Fauchet, ver Le Moniteur Universel, ${ }^{\circ} 198$ e suplemento, 27-XI-1793.
Cloots nos acusa de um projeto de lei agrária, que tal como apresentado por nossos inimigos, pareceu-nos uma loucura execrável... Nós desejamos que todo homem possua um domínio real de existência na terra, queremos, como quer toda a natureza, exceto os tiranos, que o pobre tenha o pão assegurado, que o povo inteiro não fique à mercê do rico e de sua despreocupação insolente, e declaramos que, sem esta medida para distribuir os meios de vida suficientes, não existe liberdade no mundo, só pode existir uma aristocracia infernal.

Ousaríeis dizer-nos o contrário? Oh, filósofos infames! Não ousais dizer, e vos atreveis a acusar de criminosos os amigos dos homens que ordenam, em nome da natureza, que nenhum ser vivente deve ser reduzido aos horrores arrasadores da escravidão. Mas quando dissemos que o meio para assegurar uma existência livre e suficiente a todos os homens era a distribuição das terras por igual? Estamos longe dessa ideia e a recusamos com desprezo como um pomo da discórdia que acabaria destruindo o gênero humano. Ao invés disso, aderimos àquela ideia verdadeira do autor do Contrato Social, a de que todos os pobres tenham alguma coisa e os ricos não possuam em excesso. Como a entendemos? Ah, diremos quando quisermos e for o momento... M. Cloots tem um vício capital em todos os seus escritos: o de construir sobre as leis uma moral falsa, ao invés de construir as leis sobre a moral eterna. Não quer religião alguma, porque esta constitui um liame, um liame duplo: e é verdade, é a ligação todopoderosa das consciências e o sagrado nó da virtude. Mas a sociedade jamais poderá existir em harmonia sem essa relação dos homens com o Deus da natureza e sem a relação do tempo com a eternidade. Se não for assim, só restarão filósofos mentirosos, aristocratas saqueadores, povos sem alma, crimes sem fim e a miséria no universo inteiro. Só a religião impediu os escravos de serem escravos totalmente, ao despojarem-se das paixões tirânicas do despotismo. Também será a religião que impedirá que os homens livres sejam devorados pelas paixões anárquicas da licenciosidade.

Claude Fauchet ${ }^{36}$ considera a religião parte da natureza humana, irmanando a consciência religiosa com a libertação, segundo a filosofia da natureza:

\footnotetext{
${ }^{36}$ La Bouche de fer, $\mathrm{n}^{\circ}$ 43, 16-IV-1791, p.122.
} 
A natureza concedeu ao homem com um vínculo religioso que só o orgulho dos falsos gênios ou a baixeza dos corações depravados são capazes de desconhecer, mas que conspiração alguma poderá jamais destruir, porque esse vínculo faz parte da essência geral da espécie humana e é sentido inclusive pelos ímpios em seus momentos de lucidez, como nos remorsos dos maus.

Não vos enganeis, patriotas! O cristianismo é indestrutível porque não possui, em sua substância, nenhuma característica de invenção política. O evangelho não foi composto por ambiciosos e déspotas; em cada uma de suas linhas os confunde: a igualdade santa está inscrita em inimitáveis caracteres. É o código da fraternidade pura; é a lei celestial da liberdade... Derrubai todas as estruturas impostoras que o despotismo dos governos, que gerou o despotismo dos curas e sobre o qual se firmou, ergueu ao redor deste edifício simples e majestoso. Porém, depois de varrer severamente o exterior e o interior do templo, não toqueis suas fundações: quebrantaríeis a liberdade sobre a pedra imóvel; afundaríeis o império ao invés de limar um dos fundamentos da religião.

Os ociosos que se dizem proprietários não podem receber outra coisa além do excedente da subsistência dos arrendatários; isto prova ao menos nossa copropriedade como arrendatários. Se somos naturalmente coproprietários e, na verdade, somos a única causa de toda a renda, o direito de limitar nossa subsistência e de privar-nos de seu excedente é um direito de bandidos". Assim se exprimia l'Ange em 1790. A crítica iluminista feita à propriedade, ${ }^{37}$ antes de chegar à Revolução, fora estabelecida pelo Código da natureza de Morelly (1755), em Dúvidas sobre a ordem essencial e natural das sociedades de Mably (1768) e em Investigações filosóficas sobre o direito de propriedade e o roubo de Brissot (1780), que afirmavam ser "a propriedade exclusiva um roubo na ordem da natureza". Este último autor, que afirmaria em suas memórias "a vaidade foi minha primeira motivação e o desejo de fortuna, minha segunda", seria atacado por Robespierre como liberticida e traidor principal da facção girondina.

O que parecia acontecer, na verdade, era que alguns brissotinos, membros do Círculo Social, notadamente Fauchet, e radicais populistas de

${ }^{37}$ LEV ASSEUR, E., Histoire des classes ouvrières et de l'industrie en France de 1789 à 1870, Paris, 1903 , p. 78 várias tendências apoiavam a lei agrária cujo pressuposto era a intenção de reformar profundamente a propriedade do solo, à qual se opunham os jacobinos, com Robespierre à testa, pois interpretavam-na como subversiva da sobrevivência econômica da França na ordem internacional. Daí provém a relação que se queria estabelecer entre apoiar a lei agrária e entender-se com as potências inimigas da França.

Robespierre conseguiu que a Convenção decretasse "a pena de morte contra qualquer pessoa que propusesse uma lei agrária ou qualquer outra subversão das propriedades territoriais, comerciais e industriais". Contudo, diferente de Danton, Robespierre exigia mais impostos sobre a propriedade. E Danton enfrentou, mais do que Robespierre, a Jacques Roux diretamente. De todo modo, a condenação jacobina da Convenção era sem dúvida dirigida a Roux e aos hebertistas.

Os planos econômicos jacobinos tinham o objetivo de favorecer o livre comércio dentro da França, alternando este sistema com o proibicionismo, conforme as circunstâncias da guerra. Para tanto, os princípios fisiocráticos deviam ser respeitados sem muitas reformas. No entanto, impunha-se uma política de subvenções à alimentação básica (o pão), de repressão aos açambarcadores (decretos de dezembro de 1792 e de julho de 1793) e de controle de preços (o maximum) (em setembro de 1793). Mas a política econômica jacobina não obteve os resultados esperados, pois parecia ignorar que o capitalismo, em regime de liberdade, prefere produzir dinheiro do que outros bens, e, por outro lado, o condicionamento virtuoso da economia que Robespierre pregava não surtia nenhum efeito visível. Assim, ao invés de redistribuir melhor a renda e produzir mais, o que estava acontecendo era o aumento dos negócios com dinheiro, este era depreciado, o dono do armazém perdia e o atacadista ganhava, as mercadorias eram adulteradas e retidas especulativamente. Os pobres se exasperavam e os "padres vermelhos" e os hebertistas os lideravam. Robespierre só via ali uma ameaça subversiva ao sistema socioeconômico, o único capaz de sustentar a nação. Não discernia nenhuma vantagem na direção, mais ou menos conjuntural, da economia. Ao invés de um dirigismo ágil, optou por um condicionamento ideológico indireto que não foi imposto com resultados. 
Como Menozzi ${ }^{38}$ já destacou, junto com O esforço de criação de uma religião cívica, sobrevivia a "leitura política do Evangelho". Em alguns casos, esta última chega a sobrepor-se à primeira. É o que Menozzi tenta demonstrar de modo um tanto grosseiro com o culto a Marato Entretanto, o que se deve levar mais em conta - a que Menozzi também se refere - é a presença de boa parte da moral evangélica (sermão da montanha, da última ceia, etc.) na moral revolucionária no auge da Montanha convencional. Isto quer dizer que a exigência revolucionária proveniente do cristianismo possui uma força moral mais bem aproveitada do que a proporcionada pela simples moral republicana. Em outras palavras, a maioria dos oradores da Montanha percebe na moral evangélica uma exigência que, em virtude de sua capacidade de ação direta na consciência, supera a moral republicana, mais conceitual e exterior. Assim como a moral atinge a perfeição da lei, chegando à consciência de maneira mais íntima, a moral evangélica parece chegar ainda melhor e mais absolutamente a essa consciência do que a moral republicana, mais afeita ao individualismo. É por isso, talvez, que a Convenção pós-termidoriana, frente ao Diretório, privar-se-á de qualquer referência religiosa, muito mais do que no período anterior, para não ficar às voltas com as exigências da moral evangélica mais poderosamente ameaçadora do individualismo republicano ajustado ao capitalismo moderno.

Em nome da caridade evangélica também foi defendida uma religião hábil em reformas e inimiga do radicalismo revolucionário ${ }^{39}$.

Oh, Franceses, oh, nossos pais! Queríeis ser livres! Por que, pois, fazer calar uma religião cujos preceitos, todos eles, fazem o tirano e o déspota empalidecer? Queríeis ser iguais! Por que afastar uma religião que não diferencia o rico do pobre, o fraco do poderoso, que a todos mostra o mesmo pai? Queríeis restabelecer a ordem em vossas finanças! Por que esquecer uma religião que fulmina o infiel publicano e em seu lugar ensinar uma filosofia que prega a todo mundo o interesse particular, que proclama a impunidade para as depredações do forte e para os roubos às escondidas dos fracos?...

${ }^{38}$ MENOZZI, D., Letture politiche di Gesù, Brescia, 1979.

${ }^{39}$ BARUEL, De la Religion dans les Révolutions (antes de 1792), s.1., pp. 12, 17,18,30-32 e 36.
Se pelo menos o Evangelho tivesse sido respeitado em nossas revoluções, se a religião tivesse sido escutada quando, passado o tempo das prevenções, chegara-se ao dos remédios, como seria diferente a história de todas essas regenerações, pretensas ou reais! É a religião que une as classes para alienar os corações? É a religião que só sabe arrancar sacrifícios do terror ou da embriaguez? É a religião que lança esses gritos tumultuosos, que leva ao Senado nacional mais dissensões e transtornos do que os existentes no champ de Mars? É a religião que faz nascer esses ciúmes de estado, essa rivalidade de domínio, esses debates iniciados com as arengas dos tribunos e concluídos com o ódio de um povo que aterroriza os seus nobres, os seus sacerdotes, os seus reis, que aterroriza inclusive aqueles a quem defendia?

Com o espírito do Evangelho, um mesmo zelo pelo interesse de todos teria unido os corações ...

Um dia será bem sabido e essa religião que acalma as feras será distinguida de uma filosofia que irrita os povos, que os seduz para torná-los ferozes... Esta filosofia será desmascarada... Que ouse ela então ainda chamar-se Agente de nossas revoluções! Por certo, foi ela que inspirou seus começos, proclamou seus sofismas, pôs em jogo todas as paixões, gerou todas as desordens... Será necessário por fim que o francês recuse essa filosofia perturbadora e inimiga das autoridades em todos os lugares; esta filosofia inimiga de Deus em todos os cantos do mundo, porque também é inimiga dos bons costumes..

Nesta linha contrarrevolucionária, o autor já esgrime a ideia de que a Revolução só pode ter sentido como castigo divino aos pecados dos fiéis e de seus sacerdotes. Ao mesmo tempo, porém, considera apropriados alguns decretos de iniciativa secular para a regeneração da Igreja e para dar uma lição de humildade ao clero:

Digamos que Deus chama os profanos para purificar os santos. Venha de onde vier o decreto, que importa se antes já estava no coração e nas leis da própria Igreja? Seremos humilhados! Mas essa humilhação tem um significado nos desígnios do Senhor, que nos dá um aviso para que não esqueçamos nossas leis através do opróbrio que é o mundo mostrar-se mais observante delas do que nós; do temor de que lhes dê a sanção que deve proceder de nós. 
Se a vida é injusta e só tem sentido como sacrifício, a utilidade desse sacrifício deve estar fora da vida. Deus existe então para dar sentido a esse sacrifício (premiá-lo), já que a sociedade normalmente não consegue. Assim, os discursos católicos de união entre revolução e religião logo se aproximavam da moral do deísmo robespierriano. Ante o esforço social da revolução, a religião perdia seu caráter dogmático na crença e hierárquico na instituição para se transformar em consolo e promessa de libertação do homem sociável e sacrificado para o bem de sua pátria ${ }^{40}$ :

Em todos os tempos, em todos os Povos, a Religião foi o primeiro laço de união para a Sociedade; presidiu à formação de todos os estados; só ela pode sustentá-los... sempre utilizada como suplemento à imperfeição das leis civis, que não conseguem evitar nem castigar os crimes secretos.

Qual é, na verdade, o objetivo da Religião e da política? Esclarecer a dignidade do homem; fazê-lo amar os deveres mais difíceis e penosos; reprimir os desvios de uma razão pouco dócil; acorrentar as ações e movimentos dos corações corruptos ou propensos à corrupção; fazer, em suma, do conjunto dos homens uma sociedade de amigos ou irmãos, uma única família.

Com a Religião e a Liberdade, os desejos culposos são reprimidos e os sentimentos são regulados de acordo com a utilidade pública e privada. Ambas são o contrapeso mais eficaz contra o amor-próprio, este amor a nós mesmos, tão ávido, altivo, exigente, desumano e às vezes tão rasteiro, cego, abjeto e desprezível. Só na Religião e na Liberdade o homem tira de si mesmo o que deve dar aos seus semelhantes, restituindo-lhes o bem e a honra que lhes foram arrebatados.

Ensinai aos homens que a Religião que aperfeiçoa as virtudes é a única força que pode erguê-las acima da fraqueza e colocá-las a serviço da verdadeira sociedade... Quando o respeito à Lei não deve seu princípio à Religião, não resta dele senão uma homenagem hipócrita, pois o interesse pessoal nos leva de volta aos nossos vícios...

O homem cujo coração definhou na miséria não tem para consigo mesmo a estima que deve a sua dignidade; a honra, a honradez e a
Religião perdem nele o império que costumam possuir sobre um homem bom. Sem atração pelos deveres de cidadão, o amor à pátria se extingue em sua alma abatida; o opróbrio, a infâmia, a vergonha já não lhe suscitam sentimentos capazes de assustá-lo; humilhado em sua própria consideração, não se envergonha em mostrar-se exteriormente tal como se sente por dentro. Assim, entrega-se ao vício sem remorsos; cessando o esforço na virtude, dispõe-se ao crime: à custa de si mesmo, transforma-se no inimigo dos outros e no flagelo da sociedade: se não a prejudica, ao menos se recusa a ser-lhe útil.

O interesse pela Nação já não o afeta, uma vez que é a Nação que parece abandoná-lo a todas as desgraças que sofre.

Depois de todo esse discurso de sensibilidade revolucionária, o abade Barthélemy não pode deixar de pedir recursos à Assembleia Nacional ante a negativa de seus antigos fornecedores de um foro de trigo.

Além do impulso dado às ideias e ao espírito do Evangelho pelos sacerdotes revolucionários, a aceitação popular de suas máximas devia-se também a uma tradição de ideias de igualdade vinculadas ao "verdadeiro sentido do evangelho para o povo". Isto é o que se prega abertamente nas populares estrofes do Ça ira (Vai dar certo):

Ah! vai dar certo, vai dar certo, vai dar certo./ Seguindo as máximas do Evangelho/ Ah! vai dar certo, vai dar certo, vai dar certo./ Do legislador tudo se cumprirá./ O que se eleva será rebaixado/ E o que se humilha será elevado./ Ah! vai dar certo, vai dar certo, vai dar certo./ O verdadeiro catecismo nos instruirá.

\footnotetext{
${ }^{40}$ Abade BARTHELEMY, L'accord de la religion et de la liberté, Lyon, 1791.
} 


\section{Nota sobre a franco-maçonaria}

Mathiez $\mathrm{z}^{1}$ ressaltou a proximidade entre a maçonaria e o catolicismo para o período da Revolução Francesa. Chega inclusive a dizer que esta maçonaria pode ser considerada uma heresia do catolicismo, que como o neojansenismo, pretenderia uma maior secularização da Igreja e um compromisso diferente com o mundo moderno.

A maçonaria deveria ser considerada oriunda do movimento de misticismo e heresia que tomou conta da segunda metade do século XVIII, e que foi uma reação contra o absolutismo pontifical e os abusos da Igreja romana. O iluminismo dos rosa-cruzes não é senão a manifestação extrema da heresia maçônica. Eis porque entre os membros da maçonaria figuram sacerdotes inovadores e místicos como dom Gerle, Fauchet, Grégoire, todos tentando reformar a Igreja... Até a Revolução, a filosofia maçônica pode ser considerada uma filosofia cristã.

Durante a Revolução, as lojas são extintas e seus membros se dispersam. Serão reconstituídas no fim do Diretório e sob o Consulado.

Este renascimento da maçonaria coincide com a queda das últimas religiões revolucionárias (teofilantropia, culto decadário) e com o renascimento do catolicismo... Os homens que fizeram a maçonaria reviver no ano VII (1798-99) eram do mesmo tipo que os que substituíram o catolicismo por um culto cívico, deísta e nacional. Eram uns bons burgueses. ${ }^{2}$

Chassin ${ }^{3}$ já demonstrou, contrariamente a interpretações que parecem querer ressurgir, a nula importância da maçonaria, por um lado, e dos grupos filosóficos, por outro, enquanto associações com influência política direta na Revolução. Ou seja, a maçonaria influenciou de forma abstrata através de suas ideias humanistas e de realce da sociabilidade. A tríade Liberdade-Igualdade-Fraternidade corresponde a tal influência. Mas suas lojas, em muitas das quais se reuniam pessoas de projeção política, econômica e social variada, não desempenharam papel importante enquanto

${ }^{1}$ MATHIEZ, Albert, Contributions à l'histoire religieuse de la Révolution Française, Paris, 1907, pp. 160-165 e segs.

${ }^{2} I d .$, p. 167.

${ }^{3}$ CHASSIN, CH. L., Le Génie de la Révolution, Paris, 1863, vol. I, p. 403. agentes políticos. Tampouco influenciaram enquanto instituições de espiritualidade ou religiosidade, ficando seus mistérios à margem da sociabilidade política praticada durante a Revolução.

Assim, pois, não é correta a interpretação que pretende atribuir um papel decisivo à própria "sociabilidade maçônica" na Revolução. Nem as lojas de elite atuaram no sentido da sociologia política. Em compensação, os clubes, estes sim, eram associações mais próximas do que, em princípio, são os partidos políticos, o que também é contrário à interpretação de vários historiadores modernos que desejam desvirtuar a função política dos clubes revolucionários, alegando sua inconstitucionalidade enquanto partidos num parlamento. Entretanto, a relação entre as bases sociais e os convencionais dos clubes possuía um discurso muito mais coerente (donde a força dos conflitos) que o dos partidos, os quais funcionavam como elites preocupadas apenas com seu equilíbrio recíproco. Assim, a crítica paretiana à democracia formal não se aplicaria tanto ao sistema político da Convenção (inclusive depois de Termidor) como aos partidos, que esses historiadores pretendem agora reconhecer como mais genuínos, apesar de sua difícil vinculação a uma base social reconhecível. Para percebê-lo, basta comparar (contra as versões dos historiadores da recente tendência desprestigiadora da Revolução), por exemplo, a relação existente entre as exposições de jacobinos, cordeliers e brissotinos na Convenção e as "ações na rua" com a mesma relação existente entre as "ações vadias" dos ingleses no final do século XVIII e na primeira metade do XIX, e as exposições dos "partidos" liberal e conservador, completamente afastadas dessas ações.

Soboul $^{4}$ traça com simplicidade a gênese historiográfica da ideia da conspiração maçônica na Revolução: o abade Lefranc, em 1792, o abade Barruel, em 1798, e Augustin Cochin, em 1925, numa obra "estranhamente atualizada por François Furet em 1978".

J. M. Roberts ${ }^{5}$ partilha, com fundamentos plausíveis, a opinião de que a maçonaria, enquanto instituição social, teve pouca ou nenhuma influência

${ }^{4}$ SOBOUL, A., Joseph Bara (1799-1793). Société des Etudes Robespierristes, Paris, 1981, p. II.

${ }^{5}$ ROBERTS, J. M., "The Origins of a Mythology: Freemasons, Protestants and the French Revolution", em Bulletin of the Institute of Historical Research, v. XLIV, 1971; LEMAIRE, J., "Un aspect de la pensée contre-révolutionnaire: la pensée antimaçonnique (1785-1805)", 
na Revolução Francesa, localizando a invenção intelectual dessa influência precisamente na Espanha, como consequência de uma informação exigida pela Corte espanhola sobre a França.

A sociabilidade manifestada nos agrupamentos maçônicos podia favorecer a revolução - entendida como revolução social - tanto quanto a sociabilidade exibida nas assembleias cristãs. $\mathrm{O}$ que é preciso relacionar à Revolução Francesa - e isto tem pouco a ver com as relações sociais exibidas nos locais dos ritos - é a filosofia crítica do iluminismo e a moral do cristianismo evangélico, que existiam compromissadas com a Revolução, independentemente de correlações com ritos e assembleias específicos da maçonaria ou do catolicismo.

Tanto os ideais de fraternidade e de humanismo maçons como os de caridade cristã eram sociologicamente mal representados por suas respectivas assembleias. Nestas apareciam mais representados os conflitos sociais e as diferenças aos quais esses ideais se opunham. Assim, em nome de uma igualdade ou de uma caridade mais radicais, apoiava-se uma revolução que facilmente colocava em posições antagônicas irmãos inclusive de uma mesma loja ou de uma mesma paróquia. Nem a maçonaria, nem a Igreja católica, em seu conjunto, favoreceram ou prejudicaram a marcha revolucionária. Foram os extremos ideológicos das doutrinas dessas confissões - igualdade, caridade - que fizeram a Revolução avançar, enfrentando interna e externamente muitos membros de uma mesma sociedade religiosa. A diversidade e os conflitos de interesses existentes entre artesãos, comerciantes, aristocratas, alto e baixo clero, burocratas, militares, etc., tornou-se tão importante dentro das Lojas Maçônicas como no interior da Igreja Católica.

Portanto, a maçonaria não esteve nem mais próxima nem mais distante do que o cristianismo (católico) de uma "sociabilidade democrática" maior ${ }^{6}$. Por outro lado, não se deve esquecer de que a iniciativa dos primeiros francos-maçons foi formar uma elite humanista a serviço da monarquia e até da própria religião estabelecida. ${ }^{7}$

Assim, as ideias de igualdade social, de fraternidade e de caridade enquanto imperativos morais básicos não são mais próprias da francomaçonaria do que da cristandade, e apresentam contradições semelhantes com os interesses e paixões da maioria dos membros das lojas e das igrejas.

À medida que a Revolução avança, a maçonaria se desativa. Seus objetivos ideológicos e políticos deixam de ter sentido dentro das lojas, assim como os objetivos análogos do Evangelho deixam de ter sentido no interior da Igreja Católica romana. As próprias lojas desaparecem a partir de $1790,{ }^{8}$ apesar de muitos dos membros das novas associações políticas da Revolução terem pertencido a lojas maçônicas. Nos Estados Gerais figuravam 14 representantes do clero, 83 da nobreza e 113 do Terceiro Estado. Na Assembleia Legislativa havia 107 membros de filiação maçônica e na Convenção Nacional, 103. ${ }^{9}$

A tese de Halévi ${ }^{10}$ revela a diminuta influência da maçonaria como tal nas formações políticas da Revolução, apesar dos interesses da escola do autor. Em seu conjunto - como já se queixava Fauchet -, parece que a franco-maçonaria estava comprometida demais com os interesses das camadas pertencentes ao Antigo Regime. Por outro lado, os ideários humanistas prevaleceram independentemente das associações maçônicas, da mesma forma que estas associações desapareciam quando os clubes ou sociedades da Revolução emergiam demonstrando mais compromisso e ação efetivos. em Transactions of the Sixth International Congress on the Enlightenment, ed. The Voltaire Foundation/Oxford, Bruxelas, julho de 1983.

6 YEDID-HALÉVI, Ran, La sociabilité rnaçonnique et les origines de la pratique démocratique, Paris, janeiro de 1981. Tese da E.H.E.S.S. (Ecole de Hautes Etudes en Sciences Sociales).

${ }^{7}$ Id., p. 113.
${ }^{8}$ Ibid.
${ }^{9}$ Ibid.
${ }^{10}$ Ibid.

${ }^{10}$ Ibid. 


\section{Jacques Roux: a crítica da liberdade sob o capitalismo}

Jacques Roux, "Sacerdote da diocese de Angouleme, apóstolo e mártir da Revolução", estava à frente do grupo de "enragés", ou raivosos, que acusavam a política econômica da Convenção de favorecer os traficantes de dinheiro e os especuladores e açambarcadores de bens. Em junho de 1793, Jacques Roux apresentava, em nome do grupo, o Manifeste des Enragés, assim chamado a partir da reação de indignação e aplausos que desencadeou na Convenção Nacional. Em breve, no mês de setembro, Robespierre conseguiria mandar prender os principais integrantes do grupo; alguns de seus argumentos foram depois retomados por Hébert, mas sem a mesma fundamentação, originalmente exposta por Roux. Assim dirigiu-se à Convenção em 25 de junho de 1793 na qualidade de alto funcionário municipal de Paris, eleitor do departamento e membro do clube dos Cordeliers ${ }^{1}$ :

A liberdade não passa de um fantasma quando uma classe de homens pode reduzir outra à fome com total impunidade. A igualdade não passa de um fantasma quando o rico exerce, graças ao monopólio, o direito de vida e morte sobre seu semelhante. A república não passa de um fantasma quando a contrarrevolução atua, dia após dia, através do preço dos artigos, pago por três quartos dos cidadãos com lágrimas nos olhos... Apenas os ricos têm se aproveitado das vantagens da Revolução nos últimos quatro anos. A aristocracia dos comerciantes, mais terrível que a aristocracia nobiliária e eclesiástica, invadiu as fortunas individuais e os tesouros da República num jogo cruel; entretanto ignoramos o término de suas exações, já que o preço das mercadorias aumenta de maneira espantosa da noite para o dia... A liberdade de comércio é o direito de usar e fazer utilizar, não é o direito de tiranizar e impedir o uso. Será que as propriedades dos velhacos seriam algo mais sagrado que a vida do homem? ${ }^{2}$

${ }^{1}$ ROUX, J., Adresse présentée à la Convention Nationale, Paris, 25-VI-1793 (Manifeste des Enragés).

${ }^{2}$ Para caracterizar o crime que Roux, especialmente, combatia com tanta tenacidade, os lioneses criaram os vocábulos "negocista" e "negocismo". Assim como o liberticídio era o crime por excelência das castas privilegiadas, o negocismo era $o$ dos que, independentemente de suas origens, se aproveitavam da situação econômica da revolução
Roux investe contra o sistema da Economia Política que a Revolução parece garantir; pede uma legislação contra os agiotas, os açambarcadores e os usuários por considerá-los contrarrevolucionários, sem esquecer a repressão aos nobres que medram no exército e aos contingentes de emigrados políticos que, coniventes com seus contatos dentro do país, manobram contra a Revolução. Denuncia também a inflação e os salários baixos que beneficiam os capitais investidos. Afirma serem a interpretação e a letra das leis claramente prejudiciais aos pobres e privilegiarem de modo sistemático os ricos. Não aceita as justificativas dadas pelos responsáveis das finanças na Convenção; assim, considera que o montante da dívida pública não deve justificar uma inflação, aludindo ao caso inglês, que apresenta uma dívida pública enorme e uma inflação sensivelmente menor que a da França.

Por outro lado, Roux se defende enquanto sacerdote, afirmando que se todos eles tivessem prestado o juramento cívico, combatido os crimes do fanatismo e da corte, votado a favor da morte do rei, casado com uma mulher virtuosa ${ }^{3}$, atacado os traidores das três legislaturas, assinado a petição do Champ de Mars, considerado o Papa assassino e contrarrevolucionário, votado a favor da república universal, do culto à pátria e à liberdade, etc., não teria sido necessária tanta repressão contra os curas ${ }^{4}$.

Roux detestava Fauchet porque via em sua doutrina difusa do amor e a da fraternidade, bem como em sua deferência para com a maçonaria, um claro sintoma de hipocrisia e de complacência com algumas alianças aristocráticas.

Apesar de Marat ter-se oposto ao "jacquesrutismo", Roux publicou um jornal, com o pseudônimo de "sombra de Marat", no qual atacou

para açambarcar recursos e gerar mais miséria entre a população. Em Lyon, Chalier acusou deste crime os negociantes que, ademais, pareciam buscar a aliança com o rei da Sardenha para seus objetivos contrarrevolucionários. Cf. Tableaux, op.cit., p. 377.

${ }^{3}$ AULARD, F.A., La Société des Jacobins, Paris, 1889, t.I. Cf. a sessão de 26-XI-1790.

${ }_{4}^{4}$ Compara os dados e a avaliação da biografia de Jacques Roux segundo o Dictionnaire Biographique du Mouvement Ouvrier Français, Paris, 1966, aos de TULARD, J., FAYARD, J. F., e FIERRO, A., Histoire et Dictionnaire de la Révolution Française, Paris, 1987.

${ }^{5}$ Le Publiciste de la République française par l'ombre de Marat, l'Ami du Peuple, ${ }^{\circ \mathrm{os}} 6$ e 8, agosto de 1793. 
sistematicamente os "negocistas" e liberticidas da Revolução, ou seja, a aristocracia dos negociantes de dinheiro, açambarcadores e burocratas. $\mathrm{O}$ projeto de Robespierre e dos jacobinos em geral, enquanto donos da Convenção, não passa, segundo os "jacquesrutistas", de uma burocratização, um fenecimento legislativo e executivo da Revolução, fenômeno que os radicais interpretavam usando o termo "liberticídio".

Povo, até quando fecharás os olhos à luz? Detestas os curas, e com razão, já que incessantemente embrutecem os homens para melhor despojá-los e acorrentá-los. Detestas os nobres, e com razão, porque pisoteavam seus vassalos e roubavam, ultrajavam, tudo em nome do despotismo e da lei, sem dar qualquer contribuição aos gastos públicos; e suportas agora os banqueiros, que são devoradores de homens, os banqueiros cuja pena biliosa calunia, por toda parte, a nossa Revolução; os banqueiros cujo luxo vergonhoso é um insulto ao valor e à virtude dos republicanos. Reflete!, povo de quem tantas vezes se abusou, que os banqueiros governam a seu gosto com a abundância e a fome; que reduzem teus exércitos, de um extremo a outro, à agonia e à escassez; que te açambarcam o numerário, os víveres, os soldos; que desde sempre devoraram as fortunas públicas e individuais, arruinaram uma infinidade de famílias através de falências fraudulentas; tu te convencerás da necessidade de aniquilar essa seita carnívora que despovoa a terra com o veneno lento da agiotagem.

Também te exorto a perscrutar as fortunas individuais. As fortunas dos que se têm enriquecido desde o começo da Revolução, numa época em que os bons cidadãos fizeram tantos sacrifícios e se arruinaram; sem dúvida esses novos ricos são egoístas, velhacos, contrarrevolucionários; (...) Assim, deves eliminar todos esses maus cidadãos que adquiriram domínios imensos de quatro anos para cá; esses egoístas que se aproveitaram das desgraças públicas para enriquecer; esses deputados que, antes de sua inesperada ascensão ao areópago, não tinham nem um escudo para gastar a cada dia e atualmente ocupam mansões adornadas... esses deputados, por fim, que, depois de conquistar a confiança do povo, sugaram sua existência até a última gota de sangue.

Roux afirma que "há opressão no corpo social quando um único de seus membros é oprimido". Seu ataque contra as impurezas da Revolução não tem aliados possíveis devido a sua intransigência. Assim como
Robespierre o faria de cima para baixo, Roux defende, de baixo para cima, uma moral violenta em prol da igualdade, à qual Marat e Hébert se opuseram por considerá-la impolítica, embora Hébert tenha tentado capitalizá-la depois da prisão de Roux.

Não se cansava de pedir a guilhotina para os negocistas, os agiotas e qualquer suspeito de enriquecimento. Como é lógico, o furor "jacquesrutista" se detinha mais nas fortunas difíceis de esconder, o que provocava a também lógica reação contrária da Convenção, na medida em que esta era responsável pelo comércio pacífico entre os cidadãos. Desta forma, as acusações de Roux à Convenção iam se tornando cada vez mais descaradas, o que resultou na sua detenção:

Pois bem! Nenhuma das medidas saudáveis decretadas contra os agiotas e açambarcadores foi executada. Quereis conhecer a causa disto? É que à testa das administrações estão os antigos procuradores, notários e advogados, por conseguinte, os homens interessados em fazer o povo odiar a Revolução; é que lá também estão os comerciantes, os lojistas, os falsos patriotas que detestam o regime republicano... ${ }^{6}$

Por outro lado, Roux também não deixava de defender os sacerdotes revolucionários e, contra a cobiça e a especulação burguesas da Revolução, opõe a pobreza e a virtude evangélicas. ${ }^{7}$

Roux preconizava o protecionismo econômico e ao mesmo tempo defendia a liberdade de comércio, sem chegar a defini-la claramente. Em sua proposta de reforma da Constituição, pedia o aditamento à mesma do seguinte artigo: "A nação protege a liberdade de comércio; mas castiga com a morte a agiotagem e a usura". Esta proposta foi muito aplaudida no clube dos Cordeliers e recebeu, à época, o apoio decidido de Hébert, que assim se pronunciou: "Devemos toda nossa consideração a uma ideia tão feliz porque, mais do que disfarçar os males dos infelizes, ela faz cortar o mal pela raiz".

Robespierre, no clube dos jacobinos, respondia dizendo:

$$
\begin{aligned}
& { }^{6} I d ., \mathrm{n}^{\mathrm{o}} 260, \mathrm{p} .3 . \\
& \left.{ }^{7} I d ., \mathrm{n}^{\mathrm{os}} 264,266 \text { e } 268 \text { (p. } 469\right) .
\end{aligned}
$$


Os jacobinos, montanheses, cordeliers, velhos atletas da liberdade, são caluniados. Um homem coberto com o manto do patriotismo, mas com intenções suspeitas, insulta a majestade da Convenção Nacional sob o pretexto de que a Constituição não contém leis contra os açambarcadores, chegando à conclusão de que ela não convém ao povo para o qual foi feita.

Roux - assim como Fauchet - é acusado de envolvimento no assassinato de Marat. Curiosa acusação contra os dois sacerdotes que competem com Marat pelos favores do povo. Depois de uma detenção e de uma libertação, será definitivamente preso. Roux tentará o suicídio e morrerá das consequências dos ferimentos que se infligiu. Sua condenação o acusava de "ter pregado a violação das propriedades e o envilecimento das autoridades constituídas".

\section{Félicité Lamennais: a persistência do contrato evangélico}

Deus e a liberdade. Esta divisa parece mais adequada à obra de Lamennais do que a escolhida por ele: "O que tiveres que fazer, faze-o logo". A liberdade segundo a Revolução Francesa, ou seja, não apenas a liberdade burguesa mas especialmente a liberdade perante o poder, a liberdade enquanto capacidade de exigir justiça ${ }^{1}$ :

Em menos de meio século assistiu-se à queda da monarquia absoluta de Luís XIV, da república convencional, do diretório dos cônsules, do império e da monarquia segundo a Carta: $\mathrm{O}$ que existe portanto de estável? O que existe de permanente nesse movimento vertiginoso que arrasta os povos e as suas leis, instituições e opiniões, que sobrevive sempre no fundo do coração dos homens? Duas coisas, apenas duas coisas: Deus e a liberdade. Uni-as e todos os imperativos íntimos e constantes da natureza humana serão satisfeitos e a tranquilidade reinará no único lugar onde pode reinar na terra: na inteligência. Mas, se as separais, a turvação e o tumulto aparecem e aumentam até que novamente voltem a se unir.

O verdadeiro liberalismo, que atualmente é incomparavelmente majoritário, compreende que a liberdade deve ser igual para todos, caso contrário não estará assegurada para ninguém; que os católicos têm o mesmo direito à liberdade dos que professam outras doutrinas e que, afinal de contas, o catolicismo - não o catolicismo bastardo e degenerado dos galicanos, mas o catolicismo romano, que, fato aceito pelos católicos e protestantes mais esclarecidos, salvou na Idade Média a civilização e a liberdade europeias - traz em si algo nobre e generoso que nenhuma alma generosa pode negar.

Para nós a justiça é o fundamento necessário do direito, apenas a justiça pode constituir a legitimidade do poder... é sempre a raiz imorredoura de tudo o que os homens dispõem; e nas épocas de revolução, quando nenhuma ordem legal fica de pé, a justiça se torna a lei única, a única barreira contra os horrores da anarquia.

${ }^{1}$ A ordem destas citações é a seguinte: F.R. LAMENNAIS, Questions politiques et philosophiques (Recueil des Articles publiés dans l'Avenir), 2 t., Paris, 1840. Tomo I: 16-X 1830, pp. 92, 94; 7-XII-1830, p. 153; 27-I-1831, pp. 190-191. Tomo II: 28- VI-1831, p. 79; 30- VI-1831, pp. 101-102. 
O objetivo ao qual tende a sociedade, não só na França como em toda a Europa, e em todos os lugares onde o cristianismo penetrou, é a liberdade religiosa, política e civil, quer dizer, por um lado a libertação da inteligência mais ou menos escravizada, sob todos os governos modernos, à força bruta do poder, e, por outro, uma extensão da esfera da atividade pública e particular proporcional ao desenvolvimento dessa mesma inteligência, com as garantias necessárias dos direitos resultantes desse novo Estado social.

Segundo essas relações, o movimento que existe no mundo movimento do qual o catolicismo é o princípio e será também o regulador - se parece muitíssimo com aquele que, provocado e dirigido pelos papas na Idade Média, salvou a civilização de um despotismo por parte dos soberanos, principalmente dos imperadores, que a ameaçava de ruína inevitável. Da mesma maneira, em nossos dias, a reação popular contra a força bruta começou, como domínio exclusivo, no mesmo momento em que a Igreja, progressivamente subjugada por esse poder, já não lhe podia opor nenhuma resistência eficaz; foi por isso que, desde então, os povos, desprovidos de proteção contra os excessos do poder e todos os seus abusos, tiveram que providenciar sua própria proteção, sem a qual, em muitos poucos séculos, toda ideia de direito, toda lei moral teria desaparecido da terra, e o gênero humano, supondo-se que tivesse podido conservar algum resto de vida nessa degradação inexprimível, teria sucumbido ao seu estado selvagem.

O desejo instintivo que empurra os povos para a liberdade no fundo não passa de um desejo de ordem, já que não é senão a necessidade que se sente de subordinar a força ao direito, a matéria à inteligência.

O cristianismo encontrou o mundo escravo: sua missão política era libertá-lo. Proclamado o reino da inteligência, a supremacia do espírito sobre a carne, da razão sobre a força, do direito sobre o fato, estabeleceu o sagrado e imutável fundamento da liberdade, inseparável da ordem e maior quanto mais perfeita for a ordem, pois a liberdade e a ordem se confundem em sua fonte, são infinitas tanto uma como outra em Deus.

A questão dos pobres, que não é apenas uma questão de economia política mas uma questão de vida ou morte para a sociedade, uma vez que é uma questão de vida ou morte para a maioria do gênero humano, é, mais do que nunca, uma das questões que na Europa clamam por uma rápida solução. Os antigos resolveram-na com a escravidão, e a força das coisas já a teria resolvido da mesma forma na Inglaterra, se o cristianismo não tivesse encontrado uma solução completamente diferente e que a humanidade não se cansará de abençoar, solução que significou uma barreira definitiva contra o retomo à servidão antiga... (Pois o catolicismo valoriza o trabalho em grau supremo)... O espírito protestante, transformado em espírito filosófico, tende, pelo contrário, a reduzir indefinidamente o preço do trabalho para aumentar proporcionalmente a quantidade de produtos e os lucros sobre esses produtos e, através desse procedimento, tende a aumentar sempre o naufrágio do pobre e a concentrar as riquezas nas mãos de um reduzido número de homens que traficam com os suores dos demais e especulam com sua fome. Daí decorre que, sem uma mudança total no sistema industrial, uma sublevação geral dos pobres contra os ricos seria inevitável e que, transtornada por completo, toda a sociedade pereceria entre convulsões espantosas.

Quero assinalar aqui a profícua carreira que em breve se abrirá ao sacerdócio, chamado a servir, com meios novos, a parcela sofredora da humanidade; uma vez que, seja desenvolvendo o sistema de colônias agrícolas - já experimentado com êxito -, como aplicando na indústria o princípio da associação, para benefício do pobre, seja concatenando os trabalhos industriais com os de cultivo, numa feliz combinação, a intervenção do sacerdote será sempre igualmente necessária, não apenas para dotar essas associações do caráter moral do qual dependem sua utilidade política e sua prosperidade material, como também para que um terceiro desinteressado sirva de laço entre as duas partes que deverão contratar, entre o rico que proporciona a terra e o dinheiro e o pobre que só pode oferecer o seu trabalho ao fundo comum.

O sacerdócio reassume o papel de protagonista da questão social, tal como foi constituído com a Revolução. Lamennais o faz intervir como força de moralidade e arbitragem frente às pretensões do capitalismo sobre a inteligência e a vida material. Mas a "força das coisas" a trajetória do capitalismo - acabará suplantando as boas intenções de Lamennais: da reforma, da arbitragem e do otimismo quanto às possibilidades da cooperação humana, bem como do papel civilizador do catolicismo, só restará um lamento dilacerado e desesperado ante uma liberdade cinicamente traída e uma religião respeitosa e muitas vezes servil para com as causas dos efeitos que não hesita em condenar. Lamennais acabará se obscurecendo em sua recriação da utopia conservadora (a propriedade para 
todos), seu humanismo, mais sentido do que o seu catolicismo amargo, e sua fidelidade à demanda sem resposta além da resposta provisória. Lamennais representa o auge do esforço das exigências revolucionárias à religião, sem outra saída fora a sinceridade solidária e a decepção ante os compromissos no mundo. Depois de Lamennais só têm sentido as igrejas do silêncio, da resistência ao homem em nome de Deus e da esperança que ultrapasse as igrejas. A religião torna a implantar uma filosofia que vai se desligar dela - o humanismo, o idealismo, o evolucionismo da segunda metade do século XIX -, uma filosofia sem a experiência religiosa. Será preciso esperar o século XX para que haja uma nova união de ambas.

Às vésperas da Revolução Francesa, foi a religião que mais obrigou a filosofia a se decidir sobre as questões de justiça e solidariedade humanas, preenchendo o vazio deixado pelos que questionaram Voltaire, Diderot e Helvetius. Será necessário esperar ao menos um século para que a religião torne a pressionar as filosofias alienadas da realidade total do mundo humano, das condições e relações dos diferentes povos da terra, para que tomem uma decisão quanto ao novo desafio da justiça e da solidariedade humanas: o existente entre mundos cuja identidade e segregação falam uma linguagem extremamente religiosa. Ainda hoje são as diferentes religiões do mundo que alertam e preenchem, a seu modo, os vazios filosóficos observáveis nas relações entre as culturas, nas consequências dos movimentos de colonização e nas condições de marginalização e exploração de recursos e de seres humanos.

Lamennais ${ }^{2}$ defendia uma acepção antielitista da verdade, afirmando que esta residia numa "inteligência geral", numa mensagem esperada pela imensa maioria, procedente de um "impulso maravilhoso" que conduzia ao desenvolvimento de todas "as esperanças terrestres do homem". O homem que lutava pela justiça e pela religião ligava-se imediatamente a essa verdade geral.

Ao mesmo tempo, criticava o racionalismo aplicado à moral, procurando mostrar que, onde estivesse o bem, estaria a verdade e, por conseguinte, a melhor aplicação da razão. Não que a razão mais

\footnotetext{
${ }^{2}$ Idem, começo e pp. 11, 49.

aperfeiçoada - independente de qualquer condição - fosse mais capaz de perceber o bem.

Assim, a luta pela justiça e pela religião é a confirmação da verdade, e não uma consequência da posse de faculdades que permitam atingi-la. Portanto, Lamennais defendia uma teoria segundo a qual uma determinada prática - a ação sobre a justiça e a religião - era a única que validava o conjunto da teoria (a verdade) e para todos (a "inteligência geral"). A interrelação entre a justiça e a religião, entre o cristianismo (cujo conceito já implicava necessariamente um desejo de justiça) e a liberdade formulada pela revolução, ficava nos seguintes termos:

\begin{abstract}
... o cristianismo e a liberdade, unidos inseparavelmente em sua raiz comum, são a condição necessária um do outro; e, de fato, assim como o partido liberal era hostil ao cristianismo, era também inimigo da liberdade; do mesmo modo, o poder era contrário à liberdade e igualmente inimigo do cristianismo: dessa maneira, o cristianismo não passava de religião oficial, uma religião bastarda, envilecida e servil, que o governo fabricava com suas ordens, favoritismos e opressões. Assim nos vimos diante de relações que podiam parecer estranhas: opostos ao governo e ao liberalismo, opostos a uma parte do clero e, especialmente, à maioria do episcopado. Já que o episcopado era galicano... Inicialmente pareceu-nos que o cristianismo aplicado ao mundo social pelo Papado ainda poderia evitar-lhe uma infinidade de males, regulando o movimento político que nada pode frear, realizando finalmente a magnífica aliança da ordem com o progresso, da fé com a ciência, da religião com a liberdade. Mas erramos, não há dúvida; fomos solenemente repreendidos por isto, todo mundo sabe; mas o erro talvez fosse perdoável.
\end{abstract}

Lamennais aposta, com uma lógica quase desesperada, nas consequências de uma Igreja mais fortalecida, do que libertadora, pelo menos para sobreviver. Assim, pode parecer que Lamennais efetua uma manobra de retrocesso depois de comprometer a essência do cristianismo, e em particular do catolicismo, com o avanço dos povos na justiça e na liberdade. Mas a lealdade a Roma o faz buscar alguma solução para o problema moral: a aliança do catolicismo com a opressão política se 
justificaria como nos recursos dos pobres: a sobrevivência em condições muito adversas e a necessária existência em condições involuntárias:

Devia portanto (a Igreja) aliar-se às soberanias absolutas contra as populações que lutavam para livrar-se do jugo que aquelas impunham com mais rigor a cada dia. Pensamos que a Igreja deve ter lamentado essa necessidade tão triste, mas, segundo suas ideias, não fazia senão obedecer a uma necessidade.

Essa aliança, sob outro ponto de vista, era também indispensável. Assim como a separação do povo era um fato, era preciso armar-se contra ele, procurar fora dele um ponto de apoio para poder reagir contra ele. Uma vez que se desconfiava do poder moral do catolicismo, considerado insuficiente para sua conservação, era preciso recorrer a um poder de outra natureza, e onde encontrá-lo senão numa espécie de aliança com os que dispunham da força material, enfim com as soberanias católicas ou não católicas, aliança cuja condição fundamental poderia ser assim expressa: eu, Poder Espiritual, vos apoiarei com minha autoridade porque vós, Poderes Temporais, me apoiareis com vossas armas. Assim nos salvaremos de comum acordo e salvaremos também a sociedade, cuja existência, dependente de nosso império conjunto, encontra-se gravemente ameaçada pelas cegas iniciativas dos povos.

Continuando com essa lógica de uma Igreja humilde diante do necessário confronto com a maldade, Lamennais tenta extrair sutilezas providenciais às manobras vaticanas. Lamennais, durante muito tempo, parece precisar tanto da Igreja quanto de Deus:

A Polônia sucumbe em sua luta gigantesca contra o Arimã do norte. Culpam-na de ter empunhado primeiro as armas e exortam-na à submissão. Será que o Papa ignora que a submissão significa o exílio, as minas, o cadafalso; que a submissão é também o cisma? Não, certamente, mas também sabe que não pode nada contra isto, que é preciso resignação diante dos males inevitáveis e que, se usasse outra linguagem, suas consequências poderiam acarretar a ruptura da aliança sobre a qual repousa, nestes tempos difíceis, a salvação da Igreja. Mas se quereis uma prova evidente, irrefutável, desse espírito de indulgência que é digno de elogio, considerai o seguinte. Se existe na Europa um país onde o princípio de resistência predomina

\footnotetext{
${ }^{3}$ Idem, pp. 72,75
}

ativamente, um país revolucionário no sentido mais amplo da palavra, tal país é sem dúvida a Irlanda. Há mais de meio século em estado de insurreição constante contra o Poder que a oprime. Ordenou o Papa ao povo irlandês que se subordinasse ao domínio inglês? Apresentou-lhe esta submissão como um dever? Chegou a lhes aconselhar tal coisa? Guardou-se bem de fazê-lo; conhece demais aquele povo cheio de ardor para aconselhar-lhe tais atitudes, para tentar mudar a ideia que faz de seus direitos ou pretender que renuncie aos mesmos. Ademais, o que há de se temer do governo inglês que não lhe exige tal coisa? Reservando então para outras nações mais dóceis ou mais debilitadas a grande doutrina da submissão passiva, o Papa deixa a inquieta Irlanda desenvolver-se como quer em suas querelas. Quem não aplaudiria prudência tão elevada? Poderíamos acrescentar muitos outros exemplos a essas memoráveis demonstrações da sabedoria pontifícia, mas não aumentariam em nada a admiração que já nos inspira.

Em suma e para concluir, o catolicismo está definhando e tende a se extinguir na Europa: os povos se afastam dele, os reis o atacam de forma aberta ou o confundem sordidamente. Com que meio reanimálo, fazê-lo recuperar o vigor que parece estar perdendo com o passar do tempo? Esse era o problema a resolver e frente a ele se ofereciam duas soluções. Cheios de fé nas verdades que constituem fundamentalmente $\mathrm{o}$ cristianismo, como a potência moral, harmonizando seu espírito íntimo com os instintos mais elevados da humanidade, teria sido possível, rompendo as correntes que atam a Igreja ao Estado, livrá-la da dependência que obstaculiza sua ação, associando-a: ao movimento social que está preparando novos destinos para o mundo; à liberdade para uni-la à ordem e corrigir seus desvios; à ciência para conciliá-la com o dogma eterno por meio de uma discussão sem trégua; ao povo para verter sobre suas imensas misérias as dádivas inesgotáveis da caridade divina. Podia-se, numa palavra, elevando-se acima de todos os interesses terrenos, abraçar a cruz nua, a cruz do carpinteiro nascido e morto pobre, a cruz daquele que, vivendo só pelo amor de seus irmãos, ensinou-lhes a entregar-se uns aos outros, a cruz de Jesus, filho de Deus e filho do homem, e cravá-la nos caminhos pelos quais o gênero humano avança. Era possível, ao menos assim acreditamos. Ou também se poderia refazer e estreitar ainda mais a antiga aliança com os Poderes absolutos, prestar-lhes ajuda contra os povos e contra a liberdade. Assim obtinha-se uma tolerância tal que o altar mostrava-se unido ao trono, 
apoiado na mesma força, dirigindo a cruz para o passado, confiandoa no presente à proteção dos protocolos diplomáticos, à guarda dos soldados encarregados de reprimir, com a baioneta contra o peito, as nações estremecidas. Roma escolheu este último partido. Tinha o direito de fazê-lo; e se ainda nos resta uma convicção profunda, é a de que, acima de suas próprias considerações, essa escolha foi determinada pela Providência.

Lamennais não pode deixar de defender o poder libertador do cristianismo segundo sua moral de caridade e igualdade diante de Deus. As mesmas características que, com diferentes nuanças e relações com o poder, um Fauchet ou um Grégoire já assinalavam como sendo próprias do cristianismo mais autêntico, libertador de todas as escravidões a que se entrega o homem.

No entanto, a missão de libertação social da Igreja parecia estar em confronto com as condições de sua existência material, que deviam incluir certo poder e riqueza. Diante do dilema, Lamennais opta por legitimar a política da Igreja em termos do mistério da encarnação num mundo já constituído politicamente ${ }^{4}$ :

Acreditamos que os povos que atualmente têm o sentimento de um direito social por meio do qual esperam o alívio de seus sofrimentos intoleráveis, substituindo a servidão ao poder opressivo das soberanias absolutas pela liberdade legítima, devem encontrar no cristianismo um apoio e uma norma para atingir esse objetivo sem desordens; posto que a lei evangélica. que lembra aos homens sua igualdade nativa e o laço de fraternidade entre eles, contribuiu inegavelmente para a abolição da antiga escravatura, do mesmo modo que influenciará na abolição da escravidão moderna ou escravidão política. E como certamente seria apreciada e venerada a religião celeste que, compadecendo-se de seus males, abriu, para mitigá-los, todos os tesouros de sua caridade inesgotável, e abençoou, em nome do Deus que não vê diferenças entre seus filhos, os esforços feitos em favor do fraco, do pobre, quer dizer, em favor da maior parcela da família humana, tentando assim livrá-la da tirania que alguns exercem desprezando todas as noções de justiça impressas na consciência universal! Parecia-nos que, se alguma voz pudesse atrair o mundo ao catolicismo, devia ser essa.
Por outro lado, no entanto, é verdade que a aplicação dessas ideias teria levado a Igreja a abdicar de seu poder temporal e a teria privado de todo socorro e proteção oferecidos pelos governos, não por culpa da Igreja, mas deles. É verdade que o Papa, não tendo conservado outra autoridade além de sua autoridade espiritual, não teria podido exercer pressão externa alguma sobre a prática religiosa. Assim sendo, depois de um exame sem dúvida consciencioso, o Sumo Pontífice, de acordo com o episcopado, resolveu que renunciar às vantagens materiais da Igreja equivaleria a comprometer seriamente a própria existência do catolicismo. No século em que vivemos, ainda mais importante para a Igreja a manutenção material de sua organização exterior, já que não basta a força moral intrínseca que emana de sua própria natureza. Agora, uma vez que a hierarquia se pronunciou, devemos acreditar nela, e cremos.

Mas Lamennais não pode deixar de se entusiasmar pela revolução de 1830, ressaltando a vocação revolucionária do povo francês e sua capacidade de ordem democrática, bem como a força das ideias morais no desenrolar dos acontecimentos 5 :

Os acontecimentos de julho (1830) só surpreenderam os que refletem pouco. A Europa logo entendeu sua gravidade e, embora causas muito conhecidas os tenham desfigurado momentaneamente, o futuro demonstrará que estávamos realmente diante do advento de uma nova era. De fato, um povo novo acabava de se revelar, um povo conhecedor de seus direitos e decidido a defendê-los, mas também um povo animado por um profundo sentimento de justiça humanidade, superior, enfim, a tudo que o mundo vira em termos morais. Pois onde se encontraria um segundo exemplo de uma população imensa, que ao ser arrastada por todas as paixões do combate, soube conter os ressentimentos, proibindo-se a vingança, respeitando a propriedade e mantendo, numa vasta capital entregue a sua vontade, uma ordem das mais severas, que nenhum governo foi capaz de alcançar com sua polícia e seus soldados? Assim se mostrou o povo de Paris. Assim se mostrou, se é possível, ainda mais admirável o povo de Lyon alguns meses depois. Fatos desse tipo são indícios seguros de uma revolução disposta a plasmar-se nas instituições fundamentais de um país: porque o povo que tiver, ainda que só por um dia, podido ser livre sem abusar de sua liberdade, que 
tiver podido manter-se de pé nobremente, nunca mais tornará a se submeter por muito tempo..

Voltemos aos acontecimentos de julho (1830). Alguns não souberam ver neles mais que uma sublevação bem-sucedida; nós os vimos como um movimento social, um passo dado pela humanidade rumo aos destinos reservados ao progresso intelectual e moral. No entanto, poder-se-la temer que o catolicismo, comprometido com o antigo governo, tivesse que pagar pelos erros cometidos, e esse temor, sabemos todos, preocupava vivamente o clero e os fiéis. Poder-se-la temer também que, apesar das vitórias obtidas, o desenvolvimento do princípio de emancipação fosse entravado seja pelo retomo a um sistema análogo ao que se acabava de derrubar, seja por uma falsa concepção da própria liberdade que, afastando-se da fonte da ordem e do direito, da lei moral divina, em pouco tempo teria desembocado na anarquia ou no despotismo e, o que é mais verossímil, em ambos alternadamente. Tivemos então a ideia de preservar o catolicismo das desgraças que o ameaçavam e, unindo estreitamente sua causa à da liberdade, preparar o triunfo pacífico e duradouro desta última. Tal foi, sem outra ideia preconcebida, o objetivo que nos propusemos ao fundar a publicação L'Avenir...

Lamennais, fiel a seu credo religioso e a seus sentimentos morais, expõe sem rodeios o conflito entre o capital e o trabalho ${ }^{6}$ :

Tendes o direito de criar para vós na ordem material uma existência menos precária, menos dura; de combater a fome, de assegurar o necessário para vossas mulheres e filhos, o que só falta, entre todas as criaturas, ao ser humano. E por que vos falta? Porque outros absorvem o fruto de vosso trabalho e se nutrem com ele. E de onde vem esse mal? Do fato de que cada um de vós, privado em seu isolamento dos meios para criar e manter uma colaboração real entre o capital e o trabalho, se encontra sem defesa, à mercê da cobiça dos que vos exploram a todos. Como saireis desta funesta dependência? Unindo-vos, associando-vos. O que um não pode, dez podem, e mil ainda mais... Quereis apenas, e as leis injustas desaparecerão subitamente, e a violência dos opressores se romperá ante vossa firmeza justa e inflexível. Nada resiste à união do dever com o direito.

${ }^{6}$ F. LAMENNAIS, Le livre du peuple, Paris, 1838, pp. 168, 171, 177.
De onde vem o mal na ordem material? Concluímos que, em virtude das leis feitas pelo rico em seu próprio interesse, este se aproveita quase por inteiro do trabalho do pobre, que fica cada vez mais estéril. O que se deve, pois, fazer? Assegurar ao trabalhador a parte que lhe pertence equitativamente dos produtos do próprio trabalho; deve-se, pois, não tirar de quem já tem, mas criar uma propriedade para quem se acha absolutamente privado dela.

Assim, Lamennais, recorrendo ao direito social do conservadorismo desenvolvido por Bonald, aborda mais diretamente a questão suscitada pelo marxismo: a propriedade dos meios de produção como chave da justiça social, e não a mera redistribuição em termos mais equitativos. Lamennais prossegue com sua argumentação:

Mas como chegar a isso? Por dois meios: pela abolição das leis de privilégio e monopólio e pela difusão de capitais que o crédito multiplica ou de instrumentos de trabalho acessíveis a todos.

O efeito desses dois meios, combinados ao poder incalculável da associação, seria restabelecer pouco a pouco o curso natural da riqueza, artificialmente concentrada nas mãos de poucos, e propiciar uma distribuição mais igualitária, mais justa, além de aumentá-la indefinidamente.

Com estas palavras, Lamennais não parece estar tão próximo de um socialismo revolucionário mas de um liberalismo reformado por um maior poder sindical, cooperativista e um acesso ao crédito produtivo. Contudo, não pode deixar de considerar o valor do trabalho e as condições do proletariado através de uma ótica crítica mais radical, embora submetida a uma fenomenologia religiosa ao invés de uma revolução social mais absoluta:

O trabalho liberto, dono de si mesmo, seria dono do mundo: já que o trabalho é a própria ação da humanidade no cumprimento da obra encomendada pelo Criador.

Trabalhadores, tende coragem; não falheis convosco mesmos!... Das santas máximas da igualdade, da liberdade e da fraternidade, imutavelmente estabelecidas, emanará a organização social. Os interesses privados se fundirão pouco a pouco num único interesse, $o$ de todos, porque, subtraídos à influência do frio e estéril egoísmo, todos compreenderão, todos sentirão que só no amor está a vida... Neste mundo, iluminado pelo esplendor do Ser Soberano, o sagrado 
laço que une as criaturas ao seu Autor aparecerá aos homens tal como é; e a Religião, despojada das vestes andrajosas que a cobrem, do corpo enfermo gasto pelos anos em que foi obrigado a estar prostrado como numa tumba, reaparecerá com sua pureza e sua santidade eternas. O Evangelho de Cristo, lacrado por um tempo, será aberto diante das nações, e todas poderão ler a Lei e conquistar a Vida. $^{7}$

A valorização do trabalho, a luta pela justiça e a fé em Deus: Lamennais insere a teologia na crítica da economia política capitalista, de tal maneira que estabelece um compromisso entre o conhecimento de Deus e a ânsia pela justiça ${ }^{8}$ :

E quando Deus quis que o homem trabalhasse, escondeu um tesouro no trabalho, porque Ele é pai, e o amor de um pai não se esgota jamais.

E quem faz bom uso deste tesouro, e não o esbanja insensatamente, obtém um tempo de repouso, e então se encontra como no começo da Criação.

Precisais de muita paciência e de uma coragem que não se cansa jamais: porque não vencereis num dia só. A liberdade é o pão que os povos devem ganhar com o suor de seu rosto.

Quem se pergunta o que a justiça vale profana a justiça em seu coração; e quem calcula o que custa a liberdade já renuncia à liberdade em seu coração.

A justiça e a liberdade vos pesarão na mesma balança em que as tiverdes pesado. Aprendei, pois, a conhecer seu preço. Há povos que não o conheceram e nunca houve miséria como a sua.

Se há algo realmente grande na terra, é a resolução firme de um povo que caminha sob o olhar divino, sem cansar-se um só momento, para conquistar os direitos que Deus lhe deu; que não conta suas feridas, nem os dias sem repouso, nem as noites sem sono, e que a si mesmo diz: Que importa tudo isso? A justiça e a liberdade merecem fadigas ainda maiores.

${ }^{7}$ Idem, pp. 179, 182.

${ }^{8}$ F. LAMENNAIS, Paroles d'un croyant, $6^{\mathrm{a}}$ ed., maio de 1868, p. 24, Capo XXXVIII e p. 116. A primeira edição é a que foi condenada pelo Papa.
Poderá sofrer infortúnios, reveses, traições, ser vendido por algum Judas. Que nada o desalente. Já que em verdade vos digo que quando o povo descer como Cristo à tumba, como Cristo ressuscitará, vencedor da morte e do Príncipe deste mundo e de seus ministros.

Sem considerar a obra de Lamennais, não teríamos chegado à conclusão sobre os esforços revolucionários do catolicismo. Lammenais não apenas ataca a injustiça, como descobre uma teoria crítica do capitalismo: revela aspectos das contradições do sistema capitalista como a liberdade pessoal do proletariado versus sua constituição em massa como um fator de propriedade burguesa; a exploração combinada à marginalização, contradizendo ideologias positivas da economia capitalista; a legalização de puras estratégias econômicas e a perda de força legal dos direitos reconhecidos do homem; a privatização do interesse público e sua garantia através de ideais de democracia, etc ${ }^{9}$ :

Passando por esta terra, como fazemos todos, pobres viajantes de um só dia, ouvi grandes lamentos: abri os olhos e vi sofrimentos inauditos, dores inumeráveis. Pálida, doente, desfalecida, coberta de luto e de sangue, a humanidade mostrou-se diante de mim, e me perguntei: É isto o homem? É isto tal como Deus o fez? E minha alma comoveu-se profundamente, enchendo-a de angústia essa dúvida.

Mas logo compreendi que esses sofrimentos e essas dores não vêm de Deus, de quem emana todo o bem e nada mais do que o bem, mas procedem do homem, envolto em sua ignorância e corrupto em suas paixões; e esperei, tive fé no futuro da espécie humana. Seus destinos mudarão quando ela quiser que mudem, e assim o desejará logo que ao sentimento de seu mal se unir o conhecimento claro do remédio que pode curá-lo.

Em certas épocas e em certos países, o homem se transformou em propriedade do homem; traficou-se com ele, foi vendido, comprado como uma besta de carga.

Em outros países e em outros tempos, sem tirar-lhe a liberdade, foi de tal maneira dominado, que o fruto de seu trabalho foi quase inteiramente absorvido pelos que o têm sob sua dependência. Melhor teria sido uma escravidão completa, já que o amo dos escravos pelo menos alimenta, aloja e veste seu escravo, cura-o das doenças, por

\footnotetext{
${ }^{9}$ Começo e pp. 15,18
} 
causa do interesse que tem em mantê-lo. Mas quem não pertence a ninguém é utilizado enquanto se pode tirar proveito dele e depois é abandonado. Para que serve o escravo quando a idade e o cansaço o esgotaram? Para morrer de fome e de frio num canto de rua... Aliás, todas as diferenças se baseiam no dinheiro...

Os proletários, que assim são chamados com soberbo desdém, libertos individualmente, são em massa propriedade dos que regulam as relações entre os membros da sociedade, o movimento da indústria, as condições de trabalho, o seu preço e a distribuição de seus frutos. O que lhes foi conveniente ordenar para seus interesses foi erigido em lei, e as leis foram, em sua maioria, simples medidas de interesse privado, meios para aumentar e perpetuar o domínio e os abusos do domínio de uma minoria sobre uma maioria.

Assim ficou o mundo desde que o laço da fraternidade se partiu. $\mathrm{O}$ repouso, a opulência e todas as vantagens para uns; para os outros, a fadiga, a miséria e, no final, uma cova.

Lamennais é o apogeu do caminho iniciado por Sieyes - se é que se pode falar de uma mesma caminhada, ao menos como sacerdotes ao reconhecer no proletariado os direitos do "Terceiro Estado":

Assim, em cada país, todos os que se cansam e se mortificam para produzir e distribuir os produtos, todos aqueles cuja atividade redunda em benefício para a comunidade inteira, as classes mais úteis para o bem-estar de todos, as mais indispensáveis para a conservação da sociedade: eis o povo. Se tirardes um pequeno número de privilegiados, sepultados no desfrute ocioso, o povo é todo o gênero humano. ${ }^{10}$

Sem o povo não há prosperidade alguma, não há desenvolvimento nem vida; já que sem trabalho não há vida, e o trabalho é em todos os lugares o quinhão do povo.

Se o povo desaparecesse, que seria da sociedade? Desapareceria com ele.

Lamennais considera um dever iniludível da caridade cristã mudar esse estado da humanidade, essa "iníqua violação da igualdade natural”:

${ }^{10}$ Idem, pp. 25, 67, 77
Ainda deveis saber disto. Quando o excesso de sofrimentos vos inspira a resolução de recuperar os direitos que vossos opressores vos arrebataram, então vos acusam de querer subverter a ordem, vos tratam como rebeldes. Rebeldes a quem? Não há outra rebelião possível além da rebelião contra o verdadeiro soberano, contra o povo; e como o povo seria rebelde contra si mesmo? Os rebeldes são aqueles que criam para si privilégios iníquos, que pela força ou pela astúcia conseguem subjugar o povo. E quando o povo rompe esse domínio, não altera a ordem, ao contrário, a restaura, leva a cabo a obra de Deus e sua vontade sempre justa.

Lamennais resolve também a favor da justiça evangélica outro impasse da Religião:

Lembrai-vos sempre de que à própria Pátria deveis preferir a Humanidade ... O gênero humano é uno por essência, e a ordem perfeita não existirá, e os males que assolam a terra não desaparecerão inteiramente até que as nações, abatendo as barreiras funestas que as separam, formem uma só sociedade grande e única... O patriotismo exclusivo, que não passa do egoísmo dos povos, não tem consequências menos fatais do que o egoísmo individual ... Que há de mais oposto à natureza e a suas leis do que o nome de estrangeiro? Não somos todos irmãos? E como um irmão pode ser estrangeiro a outro irmão ${ }^{11}$

Lamennais concorda com a linha de exigências religiosas à revolução (um Deus providencial para suprir a justiça humana e um culto externo o mais depurado possível) e das exigências revolucionárias à religião (a aplicação social do mandato evangélico de amor ao próximo e das bemaventuranças). Também na linha da teologia da Revolução, defende a superioridade do cristianismo em termos semelhantes aos de Fauchet:

Nascestes cristãos. Bendizei a Deus por isto. Se existe uma religião verdadeira, que une os homens entre si e ao Autor eterno de todas as coisas, o cristianismo, religião do amor, da fraternidade, da igualdade, de onde derivam tanto o dever como o direito, é a verdadeira religião. Comparai as nações cristãs às demais nações, e vede o que a humanidade deve ao cristianismo: a progressiva abolição da escravatura e da servidão, o desenvolvimento do senso moral e a influência deste desenvolvimento nos costumes e nas leis,

${ }^{11}$ Idem, pp. 139-140, 147, 153 
cada vez mais permeados por uma doçura e uma equidade anteriormente desconhecidas; as maravilhosas conquistas do homem sobre a natureza, frutos da ciência e das aplicações da ciência; o aumento do bem-estar público e individual; em suma, o conjunto de bens que elevam nossa civilização acima da civilização antiga e da dos povos que o Evangelho ainda não iluminou.

A esses inúmeros bens somaram-se sem dúvida muitos males; mas os bens procedem do cristianismo, decorrem diretamente dele; e os males vêm dos que falsearam a doutrina do Mestre ou violaram seus santos preceitos; vêm da inevitável imperfeição das formas externas, submetidas à ação dos homens e às necessidades dos tempos.

Mas não só o cristianismo é o melhor, como a religião é indispensável para qualquer convívio humano, como opinava o deísmo. Lamennais reforça ainda mais esse argumento ${ }^{12}$ :

Não o esqueçais nunca, não há nenhuma sociedade, nenhuma vida sem dever; e a religião não é em seus preceitos senão o próprio dever, e em suas doutrinas o conjunto de verdades que constituem a base imutável, eterna, do dever.

Aquele, pois, que se declara sem religião, declara-se isento de deveres, de sentimento, de crenças unânimes, do instinto universal; nega a inteligência e a consciência humanas, sua própria natureza e leis; nega a sociedade e nega a si mesmo, já que sem a sociedade como ele subsistiria, o que seria dele?

Mercier já dissera que o ateu é o homem só. O homem sem sociedade. Comte e Durkheim se anunciam nessas ideias de religiosidade radical.

Alguns podem pensar que as ideias de Lamennais não tiveram transcendência suficiente para suscitar o temor e a perseguição das mesmas por parte dos poderes mais conservadores. Entretanto, basta acompanhar a correspondência mantida por Metternich e outros sobre o caso Lamennais para perceber como eram ameaçadoras as suas ideias para a ordem conservadora. Metternich julgou que as ideias de Lammenais possivelmente atrairiam católicos e cristãos em geral à "anarquia civil". O que Metternich tentou foi obter uma condenação do Papa, enérgica e contundente, contra o incansável sacerdote católico. Metternich dizia ${ }^{13}$ :

O principal defeito - fazendo-se abstração de várias questões de dogma - da doutrina do Sr. Lamennais, é tirar a religião de sua alta esfera, da qual nunca deve descer, para transformá-la numa arma nas mãos dos políticos revolucionários. O que ele entende por liberdade da Igreja, liberdade que em princípio nenhum homem de boa-fé pode atacar, não é senão uma aplicação do radicalismo social à religião e, por conseguinte, trata-se da demolição da Igreja, não de sua libertação.

Ante o temor da difusão das ideias de Lamennais e da agitação ao seu redor na Bélgica, Metternich afirmava:

Um dos perigos é o de chocar o espírito verdadeiramente católico do povo e da parte sadia do clero belga. Outro risco é o de fazer o chefe da Igreja parecer que se pronuncia a favor do princípio revolucionário. Os seguidores de Lamennais encontraram a maneira de estabelecer uma analogia tal entre a ideia de liberdade da Igreja e o que eles pregam como libertação civil, que os espíritos fáceis de seduzir correrão o risco de confundir ambas as coisas, por mais diferentes que sejam em sua natureza. Avançar entre estes dois perigos não é tarefa fácil!

Metternich instava a Santa Sé a condenar abertamente Lamennais. Comparava-o a Chateaubriand, dizendo que nem este acreditava na Monarquia quando dizia defendê-la com o cristianismo, nem aquele na Igreja quando a defendia com o "anarquismo". Curiosamente, os finais das carreiras de Metternich e Lamennais estarão invertidos, até certo ponto, no que tange ao sucesso junto aos poderes estabelecidos: no fim de 1847, Pio IX convida Lamennais a ir a Roma para inspirar algumas reformas, embora Lamennais recuse a proposta, e em 1848 Metternich se demite ante os acontecimento revolucionários que o ultrapassam e admite ter defendido um mundo que de fato não existia. 


\section{PROGRESSOS E LIMITES DO ATEÍSMO}

\section{Volney: o ateísmo moderado}

Volney enriquece o pensamento revolucionário com suas reflexões concebidas no Egito e na Síria em 1785 e, dez anos depois, na América do Norte. Este homem que implantou cultivos tropicais na Córsega e foi professor de História na École Normale de Paris, tinha muita clareza a respeito das bases da sociedade ${ }^{1}$

O poder de um Estado depende de sua população; a população depende da abundância; a abundância depende da atividade de tudo que se cultiva, e esta atividade por sua vez depende do interesse pessoal e direto, quer dizer, do espírito de propriedade: de onde deriva que, quanto mais o agricultor se aproxima do estado passivo de mercenário, menos iniciativa e atividade possui. Ao contrário, quanto mais perto estiver da condição de proprietário livre e pleno, mais vai desenvolver as forças e produtos da terra e a riqueza geral do Estado.

Com essa declaração tão própria da fisiocracia ilustrada como do conservadorismo econômico do século XIX, Volney inicia uma trajetória que se desviará consideravelmente da avaliação moderada e prática de tais tendências. É o que podemos ver em suas Ruínas e em seu Catecismo.

No início de suas Ruínas, ou Meditação sobre as Revoluções dos Impérios, Volney já evoca a nova ótica da Revolução Francesa: "...confundindo os despojos dos reis com os do último escravo, testemunhais o santo dogma da igualdade".

O tema da meditação de Volney é a decadência dos impérios do Mediterrâneo e do Oriente Médio. Palmira é o lugar onde suas reflexões mais parecem se materializar: o império do fatalismo oriental, a dificuldade de raciocinar sobre o próprio destino e sobre a organização da sociedade, os perigos e deficiências da natureza paliados pela sociedade, a ignorância e a cobiça como principais causas dos males sociais, a função educativa e

\footnotetext{
${ }^{1}$ VOLNEY, C.F., Oeuvres Choisies, Paris, 1836, p. xxij.
}

moral que os governos devem ter, a volta dos impérios a sua barbárie inicial como causa de sua decadência: a teocracia e o espírito de conquista como retomada da superstição e da barbárie originais..

No que tange à religião, Volney critica os ministros do culto por exporem a fé mais nos hábitos do que na convicção do dever. Quanto à teologia, afirma ser sempre contrária à razão e, em seu capítulo XXII, nos fala da "Origem e filiação das ideias religiosas":

Foi só depois de ter ultrapassado vários obstáculos naturais e descrito uma longa trajetória na noite da história que o homem, meditando sobre sua condição, começou a dar-se conta de que estava submetido a forças superiores à sua e independentes de sua vontade... o sol... o fogo... Autômato por muito tempo, suportou a ação dessas forças sem perguntar-se qual era a sua causa; mas desde o momento em que quis dar-se conta, caiu em grande assombro; e, passando da surpresa de uma primeira reflexão à fantasia da curiosidade, elaborou uma série de raciocínios.

No começo, considerando a ação dos elementos sobre ele, compreendeu sua situação com uma ideia de fraqueza, de sujeição, e a situação da natureza foi-lhe sugerida por uma ideia de poder, de domínio; e esta ideia de poder constituiu o tipo primitivo e fundamental de toda ideia de divindade.

Em segundo lugar, os seres naturais, em sua atividade, proporcionavam-lhe sensações de prazer ou de dor, de bem ou de mal: por um efeito natural de sua própria constituição, concebeu em relação a eles amor ou aversão; desejou ou temeu sua presença; e o temor ou a esperança foram o princípio de toda ideia de religião.

Depois, julgando tudo por comparação e observando nesses seres um movimento espontâneo como o seu, atribuiu uma vontade a tal movimento, uma inteligência da mesma espécie que a sua; e assim, por indução, fez um novo raciocínio. Tendo observado que certas práticas para com seus semelhantes haviam surtido o efeito de modificar conforme seu desejo os afetos e a conduta dos mesmos, decidiu empregar essas práticas com os seres poderosos do universo...

${ }^{2}$ VOLNEY, C.F., Les Ruines, ou Méditation sur les Révolutions des Empires, Paris, 1791. I:6; Caps. V, VII, VIII, IX, XXI, XXII: pp. 166 e segs. 
Assim, as ideias de Deus e de religião, como todas as demais, tiveram sua origem nos objetos físicos e foram, no entendimento humano, o produto de suas sensações, de suas necessidades, das circunstâncias de sua vida e do estado progressivo de seus conhecimentos.

Quando as ideias de divindade tinham por primeiros modelos os seres físicos, então a divindade era igualmente variada e múltipla, assim como as formas sob as quais parecia agir: cada ser foi um poder, um gênio, e o universo se encheu, para esses primeiros homens, de inúmeros deuses.

E quando as ideias de divindade tinham por geradores os afetos do coração humano, experimentavam uma divisão calcada nas sensações de dor e de prazer, de amor e de ódio; as forças naturais, os deuses e os gênios se dividiram em benfeitores e malévolos, bons e maus: daí a universalidade dessas duas características em todos os sistemas de religião.

(...) Os antigos teólogos viram-se obrigados a compor três graus ou escalões de pessoas divinas que foram: $1^{\circ}$ o demiurgo ou deus criador; $2^{\circ}$ o logos, palavra e raciocínio; $3^{\circ}$ o espírito ou alma (do mundo). Eis, cristãos, a lenda sobre a qual fundastes vossa Trindade; eis aqui o sistema que, nascido herege nos templos egípcios, trasladado pagão nas escolas italianas e gregas, encontra-se hoje em dia católico ortodoxo, tendo-se convertido seus partidários, os discípulos de Pitágoras e de Platão, ao cristianismo. ${ }^{3}$

Se resumirdes a história inteira do espírito religioso, vereis que em seu começo não teve outro autor além das sensações e das necessidades do homem; que a ideia de Deus não teve outro tipo e modelo além das forças físicas, dos seres materiais agindo no bem ou no mal, quer dizer, em impressões de prazer ou de dor no ser sensivel... que em todos os sistemas religiosos suas causas e meio de propagação e estabelecimento sempre propiciaram as mesmas cenas de paixões e de acontecimentos, sempre as disputas de palavras, os pretextos de ciúme, as revoluções e as guerras suscitadas pela ambição dos chefes, pela trapaça dos legisladores, pela credulidade dos prosélitos, pela ignorância do vulgo, pela cobiça exclusiva e pelo orgulho intolerante de todos. Por fim, vereis que a história inteira do

${ }^{3}$ Idem, pp. 205, 221 espírito religioso não é senão a das incertezas do espírito humano que, colocado num mundo que não entende, quer, contudo, decifrá-lo como enigma.

Com essa história psicológica, ou pelo menos de conjectura psicológica, Volney descreve e detalha com precisão os passos dados dos primeiros críticos da "consciência europeia" aos discípulos de d'Holbach. O ateísmo como virtude humana fica assim realçado filosófica e politicamente ${ }^{4}$ :

O que é crer, se a crença não conduz a nenhuma ação? E a que ação conduz, por exemplo, crer ou não crer no mundo eterno?

(...) E os sacerdotes inquietos responderam: "Ó, legislador, somos humanos; e os povos são tão supersticiosos! Eles mesmos provocaram os nossos erros".

E os reis disseram: "Ó, legislador, os povos são tão servis e tão ignorantes! Eles mesmos se prosternavam ante o jugo que mal ousávamos mostrar-lhes".

Então o legislador dirigiu-se aos povos e lhes disse:

"Povos! Lembrai do que acabastes de escutar: são duas profundas verdades. Se vós mesmos causais os males de que vos queixais, sois vós que encorajais os tiranos com a adulação covarde de seu poder, com uma complacência imprudente, com suas falsas bondades, com o envilecimento na obediência, com a licença na liberdade, com a crédula aceitação de toda impostura: a quem quereis castigar pelas faltas de vossa ignorância e de vossa cobiça?’

E os povos enquanto isso permaneceram num humilde silêncio.

A única pretensão de Volney na prática legislativa foi "despojar de todo efeito civil as opiniões teológicas e religiosas".

Mas, no catecismo de 1793, Volney é mais tolerante com o deísmo filosófico-político que reina no campo da Convenção ${ }^{5}$.

${ }^{4}$ Idem, pp. 225, 234, 235 e 242.

${ }^{5}$ VOLNEY, C.F., Catéchisme du Citoyen Français, Paris, 1793. (Há uma edição posterior com o título de La loi naturelle ou principes physiques de la morale.) Começo, Cap.II, p. 257 e Capo XII, p. 297. 
O que é a lei natural? É a ordem regular e constante dos fatos, por meio da qual Deus rege o universo; ordem que sua sabedoria apresenta aos sentidos e à razão dos homens... Para todo homem que observa reflexivamente o assombroso espetáculo do universo, quanto mais ele medita sobre as propriedades e os atributos de cada ser, sobre a ordem admirável e a harmonia de seus movimentos, mais fica demonstrado que existe um agente supremo, um motor universal $e$ idêntico, designado sob o nome de Deus; e é tão verdade que a lei natural é suficiente para obter o conhecimento de Deus, que todo o conhecimento que, por meios estranhos à mesma, os homens pretenderam obter, foi logo considerado ridículo, absurdo, e foi necessário voltar às noções imutáveis da lei natural

Não é então verdade que os partidários da lei natural sejam ateus? Não, não é verdade. Ao contrário, eles têm ideias mais fortes e mais nobres acerca da Divindade do que a maior parte dos demais homens, já que não a mancham com todas as fraquezas e paixões da humanidade.

Estipulando que a justiça, e não a propriedade, seja a base do contrato social, Volney concorda com a ideia cristã de caridade:

A caridade não é então mais do que a justiça? Não, ela é a justiça, mas com uma nuança. A justiça estrita limita-se a dizer: Não faças a outro o mal que não queres que ele te faça; ao invés disto, a caridade, ou o amor ao próximo, chega a dizer: Faze ao outro o bem que queres receber. Assim também o Evangelho, ao dizer que este preceito encerrava toda-a lei e os profetas, não fez senão enunciar o preceito da lei natural.

Esse conjunto de citações nos leva à posição do "ateísmo moderado" durante a Revolução: convicção psicológica do ateísmo, utilidade política do teísmo, precaução ante a associação entre ateísmo e aristocracia, e acordo com a moral cristã sem comentar seus dogmas.

\section{Cabanis e Marat: a alma explicada psicologicamente}

Para Cabanis, Marat e outras pessoas fiéis à filosofia da medicina e à tradição moralista francesa a seu respeito, a relação fundamental para compreender os fenômenos humanos é a existência entre os sentimentos e o organismo físico, subentendendo a constante realização social dos sentimentos. Assim, Cabanis revaloriza o amor entre um higienismo moral e um humanismo político:

Não, o amor, tal como a natureza o desenvolve, não é essa torrente arrasadora que tudo transtorna; tampouco é esse fantasma teatral que se alimenta de sua própria ostentação, se compraz numa vã representação e se embriaga com os efeitos que causa nos espectadores. É ainda menos esta galanteria fria que zomba de si mesma e de seu objeto, que desnatura com expressão rebuscada os sentimentos ternos e delicados, e que inclusive não tem sequer a pretensão de enganar a pessoa à qual se dirige; ou essa metafísica sutil que, nascida da impotência do coração e da imaginação, encontrou o meio de molestar os desejos mais caros às almas verdadeiramente sensíveis. Não, não é nada disto. Os antigos, mal saídos da infância social, ao que parece haviam percebido melhor o que deve ser, o que é verdadeiramente essa paixão, ou essa inclinação imperiosa, num estado natural das coisas: haviam-na pintado em quadros que, embora desfigurados pelas desordens e extravagâncias que os costumes daquele tempo toleravam, eram mais simples e verdadeiros.

Sob o regime benfazejo da igualdade, sob a influência todo-poderosa da razão pública, livre, por fim, de todos os grilhões que lhe haviam sido impostos pelos absurdos políticos, civis ou supersticiosos, estranho a todo entusiasmo ridículo, o amor será o consolo, e não o árbitro da vida; ele a embelezará, mas não a preencherá. Porque quando a preenche, a degrada; e logo o próprio amor se extingue no tédio... à medida que a arte de existir consigo mesmo e com os demais, essa arte tão necessária à vida e, no entanto, quase totalmente inexistente entre nós, ou ao menos desconhecida em nosso sistema educacional (Cabanis diz que só foi cultivada pela filosofia grega, que integrava a medicina, a lógica e a moral), à medida que essa arte fizer progressos, veremos como esses fantasmas imponentes se desvanecerão, essas falsas virtudes, esses falsos bens que, por muito 
tempo, ocuparam quase a totalidade da existência moral do homem social... Desta mesma maneira, ao mesmo tempo em que a arte social rumar cada vez mais para a perfeição, quase todas essas grandes maravilhas políticas, objeto de admiração na história, progressivamente desprovidas do brilho vão que as revestia, parecerão apenas jogos frívolos, e quase sempre funestos, da infância do gênero humano. Os acontecimentos, as instituições, as opiniões que o entusiasmo ignorante deificou não merecerão mais do que um sorriso de assombro.

Marat apresenta sua obra filosófica como uma crítica ao materialismo iluminista, tentando diferenciar-se muito de La Mettrie e de Helvetius, autores que, por outro lado, imita consideravelmente. Dá por estabelecida a existência da alma e o erro do ateísmo. Situa nas meninges a alma que, a partir daí, acha-se "unida a nossos órgãos por laços impenetráveis". ${ }^{2}$

Sua contribuição ao conhecimento das "leis da influência da alma sobre o corpo, e do corpo sobre a alma" consiste na descoberta de um fluído de tipo nervoso que transmite as sensações nervosas à alma. De que maneira? Marat admite que é um mistério, o mistério da união da alma e do corpo.

Afirma que há dois sentimentos inatos: o amor por si mesmo ("As paixões têm sua origem no amor por si mesmo") e o amor das mães por seus filhos. Oposta ao amor por si mesmo existe a piedade, mas esta não é natural, pois não é comum a todos os homens. Define a piedade como "um sentimento artificial, adquirido na sociedade... esse sentimento nasce da ideia da dor e das relações travadas pelo homem com os demais seres sensíveis, já que para compadecer-se dos outros é preciso conhecer seus males".

Sem discutir a existência dos instintos, dá prioridade às reações de prazer-dor como a maioria dos materialistas iluministas; antecipando reflexões do romantismo, como as de Leopardi, diz a respeito do amor-próprio:

É o amor-próprio que nos faz contemplar com deleite as privações dos demais. É ele que proporciona a essas mulheres vaidosas, tão

${ }^{1}$ CABANIS, P.J.G., Rapports du Physique et du Moral de l'homme, Paris, 1855 (1796-97), p. 295.

${ }^{2}$ MARAT, J.P., De l'homme ou des principes et des loix de l'influence de l'âme sur le corps, et du corps sur l'âme, 2 v., Amsterdã, 1775”.Vol.I: pp. 158, 162, 165,171, 190, 196, 293, 294 e 295. conhecidas pelo nome de coquetes, um prazer secreto em ter a seus pés uma multidão de admiradores submissos, em dobrar sob sua vontade almas fortes e austeras, em multiplicar suas conquistas e mostrar seu triunfo ante os olhos assombrados de seus rivais. Foi ele que levou esses enganosos austeros, que a antiguidade ornou com o nome de sábios, a desprezar tudo o que as pessoas comuns estimam, fê-los correr sem cessar atrás do extraordinário, a aspirar às honras divinas e a arrogar-se o poder dos Deuses. Em suma, é o amorpróprio que, não podendo suportar nada acima de nós, nos faz pôr em jogo tudo o que temos para nos elevarmos; e quando vemos nossos semelhantes sob nossos pés, ele nos faz gemer e lamentar em segredo a desdita de não sermos mais do que homens.

Marat humanista, tentando um equilíbrio entre o materialismo e a moral espiritual, defendendo a sociabilidade, psicólogo sensorialista e filósofo psicologista, apresenta uma doutrina dividida entre Rousseau e Cabanis (com acréscimos e críticas à obra de Buffon) que o situa entre os moralistas mais realistas da Convenção. Mais do que Robespierre e do que sua esquerda. A questão está em saber até que ponto o seu trabalho filosófico anterior à Revolução influenciou-o no transcurso da mesma.

Como expoente do realismo moral destaca sua crítica da imaginação na prática do amor ${ }^{3}$ :

O amor, essa emoção voluptuosa, que torna um sexo necessário ao outro, é doce e moderado no estado de natureza, quer dizer, quando a imaginação se acha ausente... Está sobrecarregado o corpo do licor prolífico? O homem sente o impulso da natureza e se entrega ao mesmo com prazer, nunca com furor. Mas quando os costumes morais dessa paixão se unem a esse impulso natural; quando a imaginação, encontrando num objeto as ideias convencionais de beleza e de mérito que temos, aumenta a atração do prazer e nos mostra a posse desse objeto como a de um bem soberano, apenas então o amor se transforma numa paixão desenfreada que agita com força o nosso coração.

Ante essas proposições e depois de elogiar Catão, Marat conclui: "não é a ação que faz a força da alma, é a resistência que esta opõe às paixões”. Essa

${ }^{3}$ Idem, pp. 295, 298, 315 e 323. As comparações com Cabanis e as fontes de ambos são fáceis. 
resistência se confunde com a razão. Mas a razão pode pouco. O realismo moral nos adverte pela boca de Marat, com nuanças curiosamente evocadoras do pessimismo moral de Leopardi:

O que é mais surpreendente, porém, é que os sábios, essas pretensas almas fortes tão famosas, são realmente os mais fracos dos homens. No mesmo momento em que se crêem vencedores das paixões e cantam sua vitória, estão obedecendo ao mais imperioso dos donos, já que a razão não pode jamais contrabalançar um sentimento a não ser com outro sentimento oposto, nem reprimir uma paixão a não ser com uma paixão ainda mais forte; quer dizer, entregar a alma ao mais feroz dos tiranos, querendo, no entanto, livrá-la de uma escravidão.

O corpo e seus sentidos precedem qualquer representação. Assim sendo, quanto mais adequada ao nível e capacidade de nossos sentidos for uma sensação, mais real será. Um sensorialismo empirista acompanha, assim, o realismo moralista em Marat. Fica, contudo, pendente a relação misteriosa entre a alma e o corpo e fracamente enunciada a ideia de criação. O Marat médico de orientação física e filósofo de orientação realista é no mínimo incompatível com o político que trata na população a espécie e nas pessoas os instintos, tratamento cúmplice da cruzada moralista de Robespierre e outros jacobinos. Entretanto, a posição de Marat será brutal demais para uns e eventualmente utilizável para outros. A mesma posição como médico teria, sem dúvida, atraído aprovação unânime.

Se David escolheu expressar Marat principalmente através de seu rosto, deixemos Marat nos evocar os princípios de sua filosofia também através do rosto e do corpo humanos, presságio de filosofias do século $\mathrm{XX}^{4}$ :

Vede as produções do espírito, as obras da imaginação, as mais singulares, as que parecem afastar-se mais da natureza, sempre têm por forma objetos sensíveis ou relações entre estes objetos. A maioria de nossos pensamentos não passa de imagens corporais; e as ideias mais etéreas não existem (isto é tão verdadeiro que, para dar ao homem uma ideia da extensão, solidez, composição, impenetrabilidade, peso, etc., é preciso remetê-lo aos seus sentidos) sem serem fixadas pelos sentidos de nosso corpo: na natureza não existe obra alguma de puro intelecto.

\footnotetext{
${ }^{4}$ Vol. II: pp. 5, 8, 211, 225, 226 e 324
}

Quando queremos, por exemplo, elaborar alguma ideia de Deus, sempre o consideramos através de relações humanas, às vezes como pai, às vezes como rei glorioso, outras vezes como um senhor poderoso ou um juiz irritado. 'Quem quer se elevar até o ser dos seres e contemplá-lo em sua essência sem recorrer às imagens corporais não sabe como consegui-lo, e seu espírito inquieto se perde em sublimes meditações'. Eis por que todas as religiões se mantiveram por meio de um culto grosseiro que forçosamente interpõe objetos sensíveis entre o criador e a criatura. Um contempla a Divindade em suas obras, outro a adora sob simulacros, já que o Espírito, como o coração, só sabe relacionar-se através dos sentidos do corpo... Da mesma maneira, quando queremos elaborar alguma noção da alma, sempre a representamos como uma exalação leve, uma matéria sutil, um ser corporal, enfim, caso contrário não imaginamos absolutamente nada.

Marat termina seu livro invocando Rousseau. Antes investiga o conhecimento dos valores supremos. Conclui que, assim como a razão é mais forte quando melhor acompanhada dos sentidos, a melhor filosofia deve decorrer do exercício de boas faculdades, tanto sensíveis como da imaginação ou raciocínio puro. Mas o simples uso da imaginação debilita a razão e a realidade. Assim, a melhor impressão do Ser Supremo será a do indivíduo mais saudável: com melhores condições propiciadas por suas faculdades sensoriais em equilíbrio com a razão. Dessa maneira, Marat defende a psicologia empírica no que diz respeito à validade da percepção do mundo e das proposições a seu respeito. Marat seria censurado por uns em virtude de seu realismo moral e, por outros, de sua abertura metafísica. Em qualquer caso, o descrédito que a obra de Marat mereceu entre os ilustrados não se explica apenas por motivos intelectuais, a não ser que a avaliassem exclusivamente em função de seus plágios, também comuns entre os filósofos de sua época.

Ao considerar a obra pré-revolucionária de Marat, é preciso ter em mente que sua trajetória facilmente poderia ter sido bem diferente. Marat esteve prestes a desenvolver na Espanha uma carreira científica que lhe foi negada em seu país natal. Sob o reinado de Carlos III, oferecera seus serviços à corte espanhola para presidir uma Academia de Ciências: "seria para mim o auge da felicidade poder dedicar meus talentos ao bem de uma nação que amo e respeito... há muito tempo meu coração é espanhol".

${ }^{5}$ FAYET. J., La Révolution française et la science, Paris, 1960, p. 36. 


\section{Fatalidade e repouso. D'Holbach e sua influência}

É notável a influência de d'Holbach na obra de Charles de Moy, que, por sua vez, desenvolve de modo interessante a aplicação das ideias secularizadoras à política cultural da república. Neste sentido, convém destacar sua reflexão sobre a percepção social da morte e a atribuição das cerimônias fúnebres e dos cemitérios. Moy não se opõe à ideia de imortalidade em seu sentido pleno, mas a coloca em termos - já familiares nos rituais funerários - do descanso desta vida; quer dizer, faz com que a imortalidade ou seu desejo sejam percebidos como um sono que propicia o descanso maior, o supremo alívio que se pode alcançar nesta vida. Como em outras obras, e aqui sob a influência de d'Holbach, encontramos a imortalidade substituída pela ideia de réquiem ou descanso da vida e da morte e pela de consolo entre os sobreviventes, esta última inspirada em Rousseau.

Na verdade, a percepção da vida como uma alternância de vigília e de sono, vida consciente e vida letárgica ou metamorfoseada, foi fundamental na filosofia de alguns iluministas, de Bayle a d'Holbach. Marat ou Cabanis, ou Sade, também levam muito em conta essa alternância como chave para a compreensão dos fenômenos humanos.

Porém nos direis, como representaremos a morte? Mas não é tão difícil, já que todos os dias topais com uma imagem bem verdadeira, representada pelo sono: morrer é dormir pela última vez, dormir sem despertar, sem a esperança do retomo a essa longa vigília que chamamos de vida; ${ }^{1}$ sem dúvida é conveniente, depois de um longo e penoso trabalho, poder por fim repousar, e deixar a outros mais jovens e dispostos os cuidados, as penas e os trabalhos que por tanto tempo até nos oprimiram. A morte é essa letargia na qual entramos quando nossos corpos sucumbem à dor ou desabam sob o peso da caducidade. Assim acabam nossas misérias e nossas fraquezas; se a natureza não tivesse nos preparado esse meio digno de sua sabedoria e de sua benevolência, nossas penas e tormentos não teriam fim; tudo o que acontece com nossos corpos, depois de mergulhar nessa

${ }^{1}$ MOY, Charles A. de, Accord de la Religion et des Cultes chez une nation libre, Paris, ano IV (1795-96), capo XX. As influências de d'HoIbach, HeIvetius e La Mettrle são quase literais. letargia, já não é a morte: a morte não é senão o instante em que se passa da vida ao repouso; tudo que se segue a esse repouso já não é a morte, é o prelúdio de uma nova vida, rumo à qual a natureza se apressa a encaminhar as diversas partes, os diversos elementos que compunham nosso ser, já que a natureza, apesar de todo o seu poder, não pode organizar máquinas eternas: essas máquinas envelhecem; são compostas por tantas molas, tantos rolamentos se sucedem em movimentos, há tantos atritos que é normal que se alterem e finalmente se decomponham; mas a natureza, sempre ativa, não abandona nenhum supérfluo, e cada peça, que se transformara em inútil no sistema já caduco, encontra seu lugar em novos sistemas, onde são novamente ativas, cumprindo suas funções como se fossem utilizadas pela primeira vez...

Mas se a morte é um sono, como os antigos sempre pensaram e todas as religiões procuraram insinuar, não a representemos então sob horríveis aspectos, afastemos tudo que, nessas circunstâncias, pode nos inspirar sentimentos de horror ${ }^{2}$

Depois de aconselhar a composição de cantos fúnebres semelhantes aos utilizados para atrair o sono, prossegue:

...imitai a natureza que, quando adormece, nessa estação do ano em que parece finalmente se entregar ao repouso, faz desaparecer as variadas cores que a vestem durante as outras estações, para ficar coberta de uma alvura imensa. Então a superfície da terra se encontra envolvida, sepultada no deslumbrante sudário que as neves teceram, ao mesmo tempo em que os céus se ocultam por trás de uma imensa tela de espessas nuvens.

Assim andamos sobre a alvura e através das brumas, com o azul do céu desaparecido, com o disco radiante do sol escondido, com a interrupção do canto dos pássaros, com os campos desertos, com o sono e o entorpecimento da maioria dos animais, com a vegetação paralisada, a seiva esgotada, com as plantas oferecendo a crua imagem da esterilidade, sem folhagem, sem verdor, sem sombras, com os riachos emudecidos, sem os seus suaves murmúrios, parados em seu curso, com as torrentes metamorfoseadas em geladas rochas, e os rios, que serviam para transportar todas as nossas provisões, fixos em seus leitos e não oferecendo outra estrada além de um

\footnotetext{
${ }^{2}$ Idem, pp. 116 e 117.
} 
caminho quebradiço e escorregadio; enfim, tudo dorme, tudo repousa, tudo cala; o homem, quase o único dentre os animais, ainda está acordado e caminha sobre a terra por entre o silêncio e as sombras, assombrado com os desertos que deve percorrer e com a solidão que o envolve.

Assemelha-se então à alma, uma vez desatados os laços corporais, apagam-se todos os objetos que o faziam perceber, o horizonte se esfuma na vaguidade dos céus; errando e flutuando, por assim dizer, em meio aos espaços, a imaginação, que é de um aqui e de um agora, perde toda lembrança e gera ideias sem limites, vastas como a imensidão, profundas como a eternidade.

D'Holbach considerou, de maneira explícita, a ideia de Deus como resposta humana à experiência e ao sentimento das necessidades, sendo a divindade criada à imagem dos temores e ansiedades do homem. $\mathrm{O}$ mais imorredouro é a natureza, a matéria; o espírito - algo já afirmado pelos empiristas ingleses: "não é senão o sentido que empalidece" - é mais fraco e perecível. A morte é um retorno a outras formas materiais e não deve ser mais temida do que a maioria dos males de que se padece nesta vida. Por isto, é "um recurso de que não deve ser despojada a virtude oprimida, que a injustiça dos homens frequentemente reduz ao desespero". O homem deve experimentar a morte como um sono, "morrer é dormir", como um descanso eterno. Curiosamente, essa ideia já era predominante na celebração cristã da morte. O réquiem era mais enfatizado do que a ressurreição. Os músicos o superestimavam em sua arte, até, por exemplo, o próprio músico da Revolução, Gossec.

Essa ideia da morte teria uma influência na secularização dos cemitérios e cerimônias fúnebres da Revolução. Aos antifonários truculentos, aos horrores do inferno ou às ilusões insolentes de uma ressurreição se oporia a imagem de "Condorcet fechando os olhos de d'Alembert". À imortalidade dos corruptos se queria opor a beleza do réquiem.

Consideremos estes parágrafos de d'Holbach ${ }^{3}$ :

${ }^{3}$ D'HOLBACH, Système de la Nature, Londres, 1775. Começo do $2^{\circ}$ vol., pp. 191, 218; vol. I, pp. 268, 279, 292, 339, 396.
... a matéria existe por si só, age segundo sua própria energia e não se anulará jamais. Digamos que a matéria é eterna, e que a natureza sempre esteve, está e estará ocupada em produzir, destruir, fazer e desfazer, em seguir as leis resultantes de seu sistema necessário.

Quando queremos remontar à origem das coisas, sempre acabamos descobrindo que a ignorância e o temor criaram os Deuses, que a imaginação, o entusiasmo e a impostura os adornaram ou desfiguraram, que é a fraqueza que os adora, a credulidade que os alimenta, o hábito que os respeita, a tirania que os sustenta, com a finalidade de se aproveitar da cegueira dos homens.

D'Holbach considera a intuição do paganismo mais fiel à verdade do que a doutrina da providência divina segundo o cristianismo:

Foi chamada de divindade a causa necessária e invisível que desencadeava as ações de uma natureza na qual tudo agia conforme leis imutáveis e necessárias. Foi chamada de destino ou fatalidade a relação necessária entre causas e efeitos desconhecidos que experimentamos em nosso mundo; servimo-nos da palavra acaso para designar efeitos que não podemos predizer ou cujo nexo causal ignoramos. $\mathrm{O}$ fatalista não deve se orgulhar de seus próprios talentos ou virtudes; sabe que essas qualidades não passam de consequências de sua constituição natural, modificada por circunstâncias sobre as quais teve escassíssima influência. Não deverá ter ódio nem desprezo por aqueles que a natureza e as circunstâncias terão favorecido menos. O fatalista deve ser humilde e modesto por princípio; não se vê ele forçado a reconhecer que não possui nada que não tenha previamente recebido?

Em suma, aquele que está convencido por experiência da necessidade das coisas não pode deixar de ser indulgente. Vê com pesar que é devido a sua própria essência que uma sociedade é mal constituída, mal governada, sujeita a preconceitos e a práticas irracionais, submetida a leis insensatas, degradada pelo despotismo, corrompida pelo luxo, saturada de falsas opiniões, cheia de cidadãos frívolos e viciosos, de escravos baixos e envaidecidos por seus grilhões, de ambiciosos desprovidos de conhecimento da glória verdadeira, de avarentos e pródigos, de fanáticos e libertinos..

(...) E assim, o homem mais virtuoso pode, mediante uma combinação estranha de circunstâncias inesperadas, chegar subitamente a ser o maior dos criminosos. 
Essa verdade será, sem dúvida, considerada como terrível e horrorosa. Mas, no fundo, não suscita mais indignação do que a que nos ensina que esta vida, à qual nos sentimos tão fortemente atados, pode se perder a cada instante em virtude de uma infinidade de acidentes tão irremediáveis como imprevisíveis. O fatalismo faz o homem de bem decidir-se facilmente pela morte...

A essa linguagem da virtude ateia, natural e fatalista, Sade oporá, com os mesmos princípios filosóficos, a linguagem do desejo sentido na dor e na destruição como sendo absoluto na psicologia de uma sociedade irremediavelmente submetida às coisas.

Robespierre, seguindo os passos de Mably, proporá a linguagem da virtude patriótica, familiar e cívica como força de maior efeito social e maior satisfação para a sociabilidade. Mercier, Fauchet e especialmente Restif de la Bretonne dissolverão os princípios dessa sociabilidade numa filosofia do amor - de inspiração rousseauniana -, que em Restif se desenvolverá como antítese à teoria de Sade: o desejo de amar é maior que o de odiar ou destruir com prazer, por isso sua satisfação atinge maiores proporções.

Jacob Dupont, matemático e membro da Convenção, defenderia o ateísmo em nome da ciência ${ }^{4}$, procedendo à união de d'Holbach com o Newton que fora divulgado na França, o protótipo da razão natural em confronto com a especulação metafísica. Segundo Dupont, o desenvolvimento da razão pressuporia a garantia da liberdade. Era óbvio que a liberdade não poderia aliar-se à religião porque, ao prescindir ostensivamente da razão, esta prejudicava a manifestação inequívoca da razão e da ciência. Nesse sentido, Dupont criticava Rousseau, reivindicando, por sua vez, a tradição moralista e materialista construída em torno de d'Holbach e Helvetius. "A Natureza e a Razão, eis os deuses do homem, estes são os meus deuses!" “Admitirei de boa-fé na Convenção: sou ateu". Pronunciadas essas palavras, ergueu-se um burburinho na Convenção. As aclamações de vários de seus membros prolongaram o tumulto: "Pouco importa - ouviu-se também -, sois um homem honrado!"

${ }^{4}$. ROBINET, Le Mouvement Religieux à Paris pendant la Révolution, Paris, 1896, t.II, pp. 335 e segs.
Sénac de Meilhan, que morreria no exílio da revolução (1803), encarava positivamente as razões do ateísmo de d'Holbach ou do ateu mais publicista do período revolucionário, Sylvain Maréchal: "O medo e a esperança são os motores das ações humanas. Uma fria verdade e uma demonstração seca não gerarão jamais cidadãos zelosos ou súditos fiéis". ${ }^{5} \mathrm{O}$ ateísmo também via-se limitado por seu racionalismo sem expressão e, portanto, pouco comunicativo.

O próprio Sénac de Meilhan imputa o avanço do ateísmo e da secularização à despreocupação das elites, que deixam nas mãos do povo a salvaguarda dos valores religiosos 6 : "os livros contra a religião se multiplicaram, e a fé e o exercício das práticas religiosas foram, de algum modo, relegados às classes mais baixas da sociedade".

Para esses primeiros conservadores, a religião estava se adulterando devido a suas concessões ao racionalismo e à popularidade, às exigências racionais entre as elites e às exigências demagógicas entre a população. Trata-se de uma argumentação próxima às teses de Robespierre: o ateísmo é o novo estigma das classes aristocráticas, que o conjugam ao racionalismo egoísta, gerando o despotismo e a corrupção da república.

Parte do ateísmo não pode prescindir da ideia ou da realização de alguma liturgia. Sylvain Maréchal ${ }^{7}$ propôs a seguinte forma:

Preliminar: Um grave escândalo acontece desde tempos imemoriais. Uma mentira política, com alguns milhares de anos de antiguidade, pretende tornar ilusória a perfectibilidade da espécie humana.

Ainda não existe instituição alguma especialmente destinada a combater e a destruir a crença em Deus que, de todos os preconceitos, é o que maior mal gera. (H.S.D.):

Maréchal passa a propor o culto da sociedade dos homens sem Deus

${ }^{5}$ MEILHAN, Sénac de, Des Principes et des Causes de la Révolution en France, Londres, 1790, pp. 16-17. "O reino das ideias religiosas passou: o da liberdade parece renascer; mas, entre os antigos, o amor à liberdade tinha sua raiz no coração, era uma paixão; o que agora se manifesta tem sua raiz no espírito (inteligência), é pensado e sistemático". Idem, p. 84. ${ }^{6}$ Idem, p. 15.

${ }^{7}$ MARÉCHAL, SyIvain, Culte et Loix d'une société d'hommes sans Dieu, L'an ler de la Raison, Vleme de La République Française (1797-98), p. 77. 
I. Os homens sem Deus professam um Culto. Seu objetivo é a virtude. Nada mais.

II. Este culto consiste em proclamar as boas ações, estando vivos seus autores; e a homenageá-los depois de mortos.

III. Os H.S.D. têm um grande Livro aberto para nele reunir e conservar os traços honrosos da espécie humana.

V. Este volume, objeto material do culto dos H.S.D., deve conter todo o bem que foi e que será feito.

VI. Todos os anos um trecho do grande Livro é tornado público, encabeçando as Memórias da Sociedade sem Deus.

VII. Os H.S.D. cultuam a virtude num templo que não serviu para outros cultos.

IX. A incumbência de queimar incensos e de ornar com flores o Livro da Virtude é reservada às mulheres jovens e puras.

XIII. Os H.S.D. não defendem uma doutrina dúplice: mais verazes ou mais corajosos do que seus contemporâneos e do que os filósofos da antiguidade, dizem e publicam todo o seu pensamento.

XIV. Não abrem nenhuma escola, nem fundam uma seita, dirigida unicamente contra a Existência divina.

$\mathrm{XV}$. Seu objetivo principal é convencer o homem de que ele pode e deve prescindir de Deus, pretexto de todos os crimes e de todas as calamidades.

XVI. Sua religião é essa piedade natural que leva a se compadecer das desgraças dos demais e a unir-se para trabalhar contra as mesmas.

XVII. O pai de família leva às assembleias os seus filhos de mais de nove anos. Os primeiros lugares a eles estão reservados.
XXII. Uma hora para ouvir as verdades mais fortes é a medida do intelecto humano: mais o cansaria.

XXXVII. Os H.S.D. septuagenários também consagram a união dos jovens esposos: recusam a bênção a segundas núpcias.

LVIII. Uma sociedade de H.S.D. deve ser mais perfeita do que qualquer outra.

LX. O pai de um homicida, de uma mulher adúltera, etc., não pode permanecer entre os H.S.D.

LXI. É preciso ser pai de família, ou tê-lo sido; ou substituir o de um órfão, para entrar na associação.

LXVIII. Os H.S.D. adotam como caráter distintivo a idade e os costumes antigos.

LXX. No momento de sua admissão à Sociedade, pronunciam, com a mão sobre o Livro da Virtude, as seguintes palavras: Prometo e me entrego para combater, sem descanso, apenas com as armas da Razão, o erro fatal e enorme da crença em Deus.

LXXXIII. A Sociedade não admite nenhum indivíduo convertido ao ateísmo com a finalidade de obter a impunidade para seus crimes, seja ele padre, nobre, criado, pensionista de um príncipe, letrado da corte..

LXXXVI. Os H.S.D. recusam todo indivíduo cuja fortuna ultrapassar em mais de três vezes as suas necessidades. 
XC. Abstêm-se de entrar em questões políticas: elevados demais para descer a coisas tão miseráveis, a regeneração dos costumes ocupa-os inteiramente.

XCIX. Quando houver uma perseguição, os H.S.D. se retiram ao campo de suas comuns sepulturas.

Ali, envolvem-se em suas capas e esperam...

O ateísmo assim exposto não parece poder, precisamente em virtude de sua possibilidade social, fugir da liturgia e de uma ou outra forma de religiosidade comunitária. $\mathrm{O}$ que esse ateísmo enfatiza é a substituição da ideia de Deus pela de um dever coletivo sagrado e da emoção da fé religiosa por uma piedade considerada mais natural.

Com tudo isto, o ateísmo se aproxima muito de algum tipo de deísmo. Durkheim certamente não hesitaria em observar que se o ateísmo podia ser pensado como uma prática realizada por uma comunidade, que a entende como um dever sagrado e como uma reação de piedade natural no homem, sociologicamente deve-se falar de uma religião.

Os progressos do ateísmo durante a Revolução Francesa serão seus próprios limites: sua divulgação social, sua facilidade de congregar e celebrar e sua fácil conexão com estilos próprios à religião natural, farão o ateísmo competir enquanto religião - enquanto fé e celebração litúrgica ou social - com as outras formas de religião. Nessa situação, perderá para o deísmo e também para o cristianismo. Confrontado com o deísmo robespierrista, não poderá substituir o legado deísta da filosofia iluminista nem a crítica do ateísmo aristocratizante e enaltecedor do individualismo. Confrontado com o catolicismo, não conseguirá se colocar acima das exigências sociais - revolucionárias - da caridade cristã.

Contudo, a implantação dos cultos à Razão e à Liberdade, embora vinculados ao deísmo, também o foram a esse ateísmo praticado com religiosidade. E obras como o novo calendário revelarão algumas possibilidades de transcendência humana tipicamente naturalistas e ateias. O próprio Sylvain Maréchal, que também não deve ser esquecido como redator do Manifesto dos Iguais, divulgava em 1788 um Almanach des Honnêtes Gens, onde já dividia os meses em décadas; propunha como festas extraordinárias a do amor (31 de março), a do himeneu (31 de maio), a do agradecimento ou ação de graças (31 de agosto) e a da amizade (31 de dezembro). Cada dia recebia como invocação o nome de um sábio, de um político que se distinguisse por sua grandeza e nobreza e também dos fundadores das grandes religiões, bem como o de Thomas de Kempis e de Malebranche. As invocações de 25 de dezembro eram Jesus Cristo e Newton. A publicação desse almanaque valeu a Maréchal três meses de prisão. ${ }^{8}$ 


\section{O culto da razão e da liberdade}

Robinet $^{1}$ via no culto da razão praticado em 1793 o antecessor da religião positivista de Auguste Comte. Para tanto distinguia totalmente o culto da Razão, que associava à nascente sociedade humanista e científica, do culto do Ser Supremo e da imortalidade da alma, que identificava como um simples ato retrógrado protagonizado por Robespierre.

A tese comtiana de Robinet afirmava que a chamada "descristianização" do ano II foi uma antecipação da religião regenerada, a da Humanidade e não a de Deus². Essa religião já tencionava possuir o sistema completo das ciências em lugar dos dogmas teológicos:

O culto da Razão, com seus acessórios, sacramentos cívicos, altares da Pátria, calendário republicano, ensinamento moral, festas sociais, decadárias e anuais, não tinha outra origem, outro pressentimento, outras tendências, nem outro objetivo.

Esse argumento, juntamente com a disputa entre Aulard e Mathiez acerca da convergência ou da diferença entre o culto da Razão e o culto do Ser Supremo, careceria de interesse para nós se não fosse por uma questão que a historiografia mais recente inclinou-se a esquecer: o caráter teleológico das religiões ou religiosidades suscitadas durante a Revolução. Quer dizer, uma vez que a Revolução era vivida como uma superação social (daí a ideia de progresso da historiografia romântica e liberal radical não estar tão distante da mentalidade revolucionária), a religiosidade tinha tendência a se definir por meio de rupturas ou inovações que se fizessem sentir paralelamente às que intervinham a nível social. Assim, a encruzilhada de ideias e cultos religiosos durante a Revolução não deveria tanto ser interpretada como conflitiva, mas antes como uma recapitulação ou síntese de várias tendências, no intuito de dar-lhes uma nova forma adaptada aos novos tempos. Ou seja, a criatividade religiosa da Revolução onde o próprio ateísmo ficaria imerso - tentava fazer outro "Novo Testamento", que não significaria uma ruptura absoluta com o anterior, embora devesse dar a entender sua superação. Nesse sentido ficam mais

${ }^{1}$ ROBINET, dr., Le Mouvement Religieux à Paris Pendant la Révolution t. I, Paris, 1896.

${ }^{2}$ Idem, p. 7. nítidas as manobras ideológicas intentadas por todas as iniciativas religiosas da Revolução: recapitular "Antigos Testamentos" (cristianismo, judaísmo, deísmo e inclusive o islamismo) para melhor legitimar o "Novo Testamento" ou religião revolucionária. Dessa maneira, embora a ênfase parecesse recair na nova religião revolucionária (ateísmo, deísmo patriótico, cristianismo evangélico, teofilantropia, deísmo filosófico, etc.), nenhuma apresentação deveria deixar de lado sua legitimidade histórica, seu "Antigo Testamento", para, precisamente, poder englobar e dialogar com todas as expectativas e projeções de uma religiosidade que pudesse parecer mais extensa e poderosa, e dialogar com elas.

Dito isso, passemos a considerar a celebração ou culto da Razão. O contexto da famosa festa da Razão celebrada em Notre-Dame em 10 de novembro de 1793 foi integrado por acontecimentos muito significativos: o decreto de panteonização de Marat, a detenção dos partidários de Danton, a paródia do culto católico representada na Convenção por membros da seção da Unidade (20-XI), a posterior ordem de fechamento de todos os locais de culto de Paris (23-XI) e a despanteonização de Mirabeau (25-XI).

Révolutions de Paris ${ }^{3}$ afirmava, referindo-se à festa da Razão, que até a realização da mesma não houvera um triunfo tão definitivo a favor da liberdade e da religião verdadeiras. Lamentando que "os sacerdotes, desde o início, quiseram se apoderar de nossa revolução", ${ }^{4}$ pois regozijavam-se com o rumo dos acontecimentos. A revista de Prudhomme, Maréchal, Loustalot, Chaumette, Fabre d'Églantine, etc., estava decidida a acabar com a iniciativa de uma parte dos católicos a favor da Revolução. Para tanto, incentivava uma devoção e um culto mais estritamente cívicos, patrióticos e seu: referências tão explícitas ao deísmo e sim, em troca, às virtudes da filosofia e da nova república.

A interpretação dada por Révolutions de Paris à Festa da Razão em Notre-Dame parece querer evitar tanto o batismo evangélico da Revolução como sua paganização deísta. Robespierre logo veria nela uma manobra dos indulgentes dantonianos e dos demagogos do Pere Duchêne, Hébert.

\footnotetext{
${ }^{3} \mathrm{~N}^{\mathrm{o}} 215,23-30$ de Brumário do ano II = 13-20 de novembro de 1793.

${ }^{4}$ Idem, p. 210.
} 
Esta cerimônia não se parecia em nada a essas patuscadas gregas e latinas $^{5}$; assim, tocava diretamente à alma. Os instrumentos musicais não soavam de forma alguma como os órgãos das Igrejas. Era uma música republicana: colocada ao pé da montanha (elevação de madeira no coro da basílica e sobre a qual erguia-se um pequeno templo dedicado à Razão), a orquestra executava, em estilo vernáculo, o hino ${ }^{6}$ que o povo entendia tanto melhor porque expressava verdades naturais e não encômios místicos e quiméricos. Enquanto escutava-se essa música majestosa, via-se duas fileiras de moças, vestidas de branco e coroadas com folhas de carvalho, descer e atravessar a montanha, com tochas nas mãos, e depois tomar a subir a montanha na mesma direção. A liberdade, representada por uma bela mulher (Srta. Aubry), saía então do templo da filosofia e la até um assento ornado de folhagens para receber as homenagens dos republicanos e republicanas, que cantavam um hino em seu louvor, estendendo-lhe os braços. A liberdade a seguir descia para tomar a entrar no templo, parando antes e voltando-se para dedicar um olhar benfazejo a seus seres queridos. Assim que entrou, o entusiasmo irrompeu em cantos de alegria e em juramentos de nunca cessar de lhe ser fiel.

Como a Convenção Nacional não pôde assistir a esta cerimônia de manhã, ela foi repetida à tarde em sua presença. ${ }^{7}$

Não houve, digamos, apenas preocupação com o espaço entre a sessão da Convenção, que tão dignamente enterrou o fanatismo, e o dia em que foi celebrada essa vitória grande e eterna: tudo foi convenientemente ordenado e é preciso destacar, em especial, o cuidado que se teve em representar a liberdade com uma mulher

${ }_{6}^{5} \mathrm{~N}^{\mathrm{o}} 214$. David parece ser o destinatário dessa crítica.

${ }^{6} \mathrm{O}$ hino à Liberdade. Letra de M. J. Chénier e música de Gossec.

${ }^{7}$ A Convenção estava dividida e preocupada. No dia seguinte Bailly seria executado, como na véspera fora executada Mme. Roland. Chaumette - tão admirado por Michelet convenceu parte da Convenção a participar da festa à tarde, mas muitos não compareceram. A desculpa por não ter ido de manhã foi para não interromper uma sessão que aparentemente não tinha nada de importante ou extraordinário. No dia seguinte, a Convenção também não quis encaminhar a petição de exclusividade para o culto da Razão e da Liberdade, suprimindo todos os demais. Segundo Durand de Maillane (Histoire de la Convention Nationale, Paris, 1825, p. 182), a metade dos convencionais não assistiu à celebração do culto da Razão. viva, e não com uma estátua. ${ }^{8}$ Desde o novo começo se quis desacostumar os espíritos de qualquer espécie de idolatria; evitou-se, com toda certeza, substituir o santo sacramento por um simulacro inanimado da liberdade, já que os espíritos grosseiros poderiam ser induzidos a erro se no lugar do deus de pão simplesmente tivesse sido colocado um deus de pedra; as superstições já não são necessárias aos homens: se derrubamos os cultos fraudulentos, não foi para continuar ludibriando com outros, apresentando novos objetos capazes de iludir a imaginação e o coração. Essa mulher viva, apesar de todos os encantos que a embelezavam, não podia ser deificada pelos ignorantes, tal como teria acontecido com uma estátua de pedra.

Trata-se de algo que não se deve cansar de repetir ao povo: a liberdade, a razão e a verdade não passam de seres abstratos. Ma isso não quer dizer que sejam deusas, já que, corretamente falando, são partes de nós mesmos.

A liberdade não é senão nossa vontade, que tem o poder de se manifestar e de se realizar. A razão não é senão essa faculdade que está em nós de captar a natureza e as relações entre as coisas; e a verdade, por fim, não é senão a própria natureza. É a relação real e primitiva das coisas, não é uma parte de nós mesmos que desejamos adorar; isto seria adorar nossas próprias pessoas. Ao realizar a festa da liberdade, da razão, limitamo-nos a festejar as vantagens que nos proporciona esta porção de nós mesmos que se regenera, que se desenvolve em nós para nos beneficiar. ${ }^{9}$

Se qualidades abstratas e metafísicas são preconizadas, é através de uma linguagem figurada, é porque essas maneiras de falar ${ }^{10}$ desencadeiam mais presteza e vivacidade nos discursos e nas grandes assembleias. Os organizadores das festas devem portanto evitar dar falsas ideias aos ignorantes colocando estátuas sobre um altar. Inclusive talvez tenha sido um erro ter-se dado, em Paris, o nome de

${ }^{8}$ Embora a atuação dessa deusa faça pensar mais em quadros escultóricos, de acordo com o estilo praticado pelo próprio David.

${ }^{9}$ Depois de criticar a idolatria, o que não deixa de ser uma crítica original do judaísmo e do cristianismo, passa-se a celebrar as qualidades naturais, celebração típica da ideia de criação tal como era transmitida pelos deístas.

${ }^{10}$ É curioso como, em mais de uma oportunidade durante a Revolução Francesa, ideias foram defendidas ou atacadas em função das consequências sociais da "maneira de falar" das mesmas. 
templo da razão a sua ex-basílica metropolitana; teria sido melhor chamá-la de casa da verdade; considerando que os altares, os templos, tudo isso que um culto pressupõe, também pressupõe sacerdotes; então pouco importa que esses sacerdotes sejam idólatras ou católicos, todos têm o mesmo espírito, é sempre para sua própria vantagem, para seu próprio interesse, que diversificaram a impostura e o engano segundo as conveniências das épocas e dos lugares. Que os organizadores das festas, se quiserem seguir o exemplo de Paris e lançar mão de uma mulher para representar a razão, façam amanhã uma escolha digna da festa, ${ }^{11}$ que ofereçam à vista do povo urna mulher cuja conduta torne a beleza respeitável, cuja sobriedade de costumes e apetites, cuja reputação sem mácula, afastem a tolerância de desejos e propósitos ocultos; que a encarregada de um papel tão augusto, longe de aviltar a liberdade ou a razão, cuja imagem encarna momentaneamente, imprima em todos os corações, com sua presença, o devido respeito.

Por outro lado, os cultos da Razão e da Liberdade não podiam manter-se unicamente como celebrações filosóficas. Sua força precisava ser unida ao patriotismo e o anticatolicismo associado à defesa do Estado, o que aparece claramente no contexto da guerra com a Espanha. As festas da Razão e da Liberdade tornaram-se notáveis nas terras fronteiriças onde se encontravam "os heróis da liberdade e da igualdade contra os lacaios da Inquisição e os seguidores dos déspotas". ${ }^{12}$

Joseph Mongin, capitão do exército francês, elaborou um culto decadário, enquanto estava preso na Belle-Tour de Reims, pelos termidorianos ${ }^{13}$.

O Culto em questão não foi pensado em princípio para ser executado publicamente. $\mathrm{O}$ autor - encarcerado pelas manobras de alguns de seus colegas à frente dos quais se encontrava seu coronel -, habituado à vida turbulenta de soldado, viu-se condenado à inatividade física; nesse estado, as ocupações do espírito se tornam um recurso... Tal foi a primeira causa dessa obra que se realizou nos calabouços da Belle-Tour de Reims.

${ }^{11}$ A escolha da atriz Aubry não fora do agrado de todos.

12 O representante da Convenção nos altos e baixos Pirineus, Orthez, 10-11-1794: Recueil des Actes du Comité de Salut Public, Paris, 1971, supl. ao t. VI

${ }^{13}$ Messe des sans-culottes chantée à la Belle-Tour de Reims (ed. 1854), pp. 45 e segs.
Como é impossível resistir à linguagem da liberdade, cada um dos detentos tomou parte prazerosamente como ator ou espectador desta cerimônia; todos participaram com o silêncio, com o recolhimento que demonstra o recebimento pela alma das impressões que lhe querem comunicar.

Assim, de dez em dez dias transformávamos um lugar sempre habitado pela desgraça, às vezes pelo crime, amiúde pela inocência perseguida, num templo erguido à Liberdade.

Segue-se o texto da "Missa decadária", verdadeira réplica litúrgica da missa católica, com inversões simbólicas evidentes:

\section{Missa Decadária}

Nota - O Sumo Sacerdote, o primeiro Ministro, não deve usar nenhum traje especial. Deve estar vestido de soldado, ou usar a faixa de magistrado do Povo. Na medida do possível, deve ter uma voz dotada de extensão e emoção...

A sala está escura, a estátua da Liberdade se encontra sobre o altar colocado ao fundo do templo.

O Sumo Sacerdote (pegando um copo cheio de vinho das mãos do mestre de cerimônias, que deve se colocar atrás dele):

"Que esta libação seja hoje o sinal da aliança de todos os franceses. É em tua honra, ó Divindade tutelar da França, que derramamos este vinho sobre a terra, que o sangue de nossos inimigos umedeça assim a nossa terra natal. (Derrama o vinho no chão.) Que nossos prazeres se transformem em vitórias, e que a vitória seja para nós um prazer."

O Sumo Sacerdote (no meio do altar):

Glória: "Glória seja dada, no céu e na terra, aos homens livres. Nós te glorificamos, te bendizemos, te adoramos santa liberdade, porque asseguraste ao povo francês uma felicidade imorredoura, aniquilando os animais ferozes que viviam de seu sangue, conduzindo Luís Capeto, os brissotinos, fuldenses e outros à Guilhotina..."

Sumo Sacerdote: "Que a Igualdade esteja entre nós”.

Ministros: "Que nos una com os mais suaves laços".

Credo: "Creio na declaração dos direitos do homem..." 
Um ministro: "No início da criação, a igualdade reinou entre os homens. Os produtos da terra eram de propriedade comum e o grande autor da natureza colocara no coração dos humanos a necessidade de se amarem uns aos outros. Assim, a fraternidade teve como fonte sublime a nossa existência, nasceu com a nossa espécie. Esta idade feliz durou apenas um instante. Logo o preguiçoso pretendeu viver do campo de seu vizinho, abandonando o cultivo do seu próprio. Aquele que foi dotado de uma constituição vigorosa logo se aproveitou de sua força para arrancar do fraco o fruto de seu trabalho. Desses dois tipos de indivíduos nasceram os padres e os nobres, e as santas leis das Igualdades foram aniquiladas. Os primeiros urdiram uma religião insensata que legitimou sua rapina e deu-lhes um caráter sagrado, abusando de nossa credulidade e nos submergindo num dilúvio de males. Os segundos, menos culpados, apresentaram-nos a espada que os armava e nos persuadiram de que só se utilizariam dela para nos defender; mas abusaram, transformaram-nos em servos, e de protetores passaram a tiranos. $O$ povo se achava mergulhado na superstição e no fanatismo, o pão que o alimentava era um pão de dor e amargura, a vida das gerações não era senão um círculo de calamidades. Todavia, um anjo de luz planou um instante sobre a França e nossa cegueira desapareceu; lembramos de nossos direitos usurpados e imprescritíveis; indignados por uma longa opressão, criamos uma Pátria para nós. A partir desse momento, nossos déspotas e nossos padres corruptores foram ignominiosamente expulsos. O sangue dos culpados serviu de vingança à França traída, e o estandarte da Liberdade foi cravado nas ruínas da Bastilha. Desde esse tempo, o sentimento de nossas desgraças passadas nos faz ter mais apreço por nossa nova existência; fiéis às leis da natureza, defenderemos a Igualdade até o último suspiro, nossos filhos abençoarão nossa memória e viveremos eternamente na memória dos justos."

Os ministros põem incenso nos turíbulos. Ao mesmo tempo, outros dois ministros ou dois participantes trazem com gravidade um boneco representando um rei coroado. Depositam-no ao pé do altar... O sumo sacerdote corta a cabeça do tirano, todos os participantes gritam: "Viva a república! Viva a república!".

Além da inversão simbólica de diversos aspectos da liturgia católica, essa missa sans-culotte reflete a mescla dos cultos da liberdade, da igualdade e do Ser Supremo, bem como o papel das pantomimas nas representações da época, fenômeno mal interpretado num período que apenas começa a redescobrir a força da pantomima.

A ideia de poder separar de modo absoluto os interesses e a atividade do Estado da moral e espiritualidade da Revolução é uma ideia que nunca triunfa no período revolucionário. Na verdade, essa ideia não chega a se impor com certa normalidade antes do Diretório. Contudo, algumas interpretações teleológicas, algumas coetâneas, embora distantes, como a de Fichte ${ }^{14}$ afirmaram que a Revolução Francesa operara conscientemente essa divisão. Mas não foi assim. Em princípio, a própria religião católica protagonizou a celebração da Revolução e influenciou a apresentação dos fatos. Depois, serviu ao Estado, enquanto o Estado também procurava outras saídas religiosas (cultos revolucionários, filosóficos, patrióticos) para sua legitimidade e força históricas. Finalmente, a preocupação moral em tomo da política e o apego à religiosidade popular, tanto da direita como da esquerda, ocupam os pensamentos da última etapa da Convenção, antes e depois do Termidor. Até a época do Diretório, não obtém hegemonia a ideia liberal que Fichte atribuía erroneamente à Revolução: a separação estrita entre o Estado e a Igreja, a Política e a Religião, no sentido de separar o mundo considerado visível e civil do mundo encarado como invisível e espiritual. Afirmando que a natureza diversa da religião impossibilitava seu contato racional ou sensível, Fichte deixava assim a política livre de qualquer condicionamento que não fosse o de sua própria racionalidade. $\mathrm{O}$ mesmo ocorria no caso da economia. É esse aspecto liberal que Fichte atribuía à Revolução Francesa. Mas o que esta fez foi precisamente continuar procurando os condicionamentos morais e religiosos da política e da economia, já que de outro modo elas eram consideradas indignas de serem vividas por homens livres. E isso foi sentido tanto por católicos fervorosos e consequentes como por revolucionários humanistas ou deístas. O liberalismo surgiu apesar dos esforços morais de grande parte dos líderes da Revolução, não graças a eles. Em suma, a representação liberal do mundo capitalista com seus corpos autônomos e dotados de uma lógica interna - econômica, política, etc. - não foi propiciada pelo esforço

${ }^{14}$ FICHTE, J. G., Considérations destinées à rectifier les jugements du public sur la Révolution Française, précédées de la revendication de la liberté de penser auprès des princes de l'Europe qui l'ont opprimée jusqu'ici (1793), Paris, 1858. Especialmente pp. 320 e segs. 
revolucionário de tomar parte desses "corpos", conseguindo assim uma responsabilidade ou um compromisso que permeasse todas as atividades da sociedade. O liberalismo surgiu com a Revolução, mas também é preciso dizer que apesar da Revolução. Nesse sentido, a Revolução Francesa não foi tão burguesa quanto a transição ocorrida entre os séculos XVIII e XIX, cuja duração estaria vinculada às mudanças lentas que acarretaram a supremacia do sistema capitalista nas formas de reunir e distribuir a população; produzir, distribuir e trocar bens; expropriar, transpor e apropriar esforços e coisas; e lutar contra tudo que se opusesse a essas tendências, às vezes mais escamoteadamente, às vezes mais abertamente.

É o Diretório republicano que vai afirmar sem rodeios não apenas a separação mais estrita entre Igreja e Estado em tudo que se refere à cidadania e seus direitos, como também a substituição mais absoluta das finalidades morais e dos métodos religiosos pelos da moral da república leiga. Essa laicização não terá, contudo, nenhum escrúpulo em imitar ou retomar procedimentos típicos da religião para os seus objetivos, questão ainda mais embaraçosa durante o período convencional. Essa atitude se reflete nas propostas de Mentelle em plena euforia republicana do Diretório $^{15}$ :

Depois de ter refletido com rigor acerca das bases que o Legislador deve adotar para assentar sólida e convenientemente a Instrução necessária a toda a República, creio que posso provar:

$1^{\circ}$ Que não deve ocupar-se em absoluto com nada que possa se relacionar com a religião;

$2^{\circ}$ Que deve considerar única e exclusivamente a moral;

$3^{\circ}$ Que para ensiná-la com. eficácia e fazê-la germinar em todos os corações, é preciso empregar os meios usados anteriormente para o ensino da religião católica.

(...) Creio poder assegurar que a moral, uma vez instalada no coração do homem, será tão duradoura como o foram os preconceitos religiosos; e, ademais, será melhor e mais útil.

${ }^{15}$ MENTELLE, Mémoire lu à la Classe des Sciences morales et politiques de l'Institut national, 3-IX-1797, pp. 3,12 e 13
Porém, dir-me-ão, como tomar a moral tão poderosa e conseguir darlhe um império tão universal? Eis aqui minha resposta. Não há outros meios para tanto a não ser os que foram utilizados para perpetuar o ensino da religião...

Mentelle propõe que o professor de primeiro grau também desempenhe o papel de educador moral, e que a alfabetização, unida ao conhecimento dos novos valores morais, substitua a cidadania católica, outorgada pelo batismo, pela cidadania republicana. Assim, a alfabetização e o catecismo republicano dariam o "batismo" ao cidadão da República. 


\section{A teofilantropia.
A força do deísmo comparada à do ateísmo ante o catolicismo}

O opositor mais próximo ao ateísmo durante a Revolução foi o deísmo, demonstrando que este, ao contrário da afirmação dos prosélitos cristãos, nem era um ateísmo disfarçado nem o seu prelúdio. Pelo contrário, quando desfrutou de maior liberdade, apresentou-se como inimigo vigoroso do catolicismo e de qualquer religião derivada do vício eclesiástico, tanto quanto - e com força igualou ainda maior - inimigo sistemático do ateísmo. Portanto, o desenvolvimento do deísmo durante a Revolução deve ser considerado como um dos limites ao progresso do ateísmo. A força do deísmo parecia basear-se principalmente em três fatores: a associação do ateísmo a vícios aristocratizantes, a persistência da linguagem da moral na religiosidade e o maior compromisso patriótico e republicano do deísmo francês em comparação ao cristianismo revolucionário, mais cosmopolita e menos beligerante.

Assim como acontecia com o ateísmo, que não conseguia escapar das formas sociais e litúrgicas de uma institucionalização religiosa, o deísmo difundiu-se durante a Revolução com formas análogas. Uma das mais significativas foi o culto teofilantrópico. E um de seus textos básicos foi o Traité de la Religion Naturelle 1 de Pithou de Loinville. No parágrafo que citamos a seguir, observemos como o ataque contra o ateísmo e o materialismo é do mesmo calibre - e se conjuga num mesmo propósito que o ataque suscitado pelo farisaísmo e pela corrupção eclesiástica. Nesse sentido, são igualmente anatematizados a imoralidade e o fanatismo, da mesma maneira como já fazia toda uma tradição deísta do Iluminismo.

Expulsar o fanatismo e a superstição, purificar de toda licença o solo da liberdade, limpar o ar e a terra do contágio do ateísmo, combater os horrores monstruosos e sanguinários dos sacerdotes; perseguir a espantosa hidra dos erros até sua aniquilação mais absoluta; este é nosso cometimento... É preciso derrubar o jugo de todas as imposturas fanáticas, políticas e supersticiosas. Mais ainda, é preciso castigar com rigor extremo os corruptores dos costumes morais. É

${ }^{1}$ PITHOU DE LOINVILLE, J. J., Traité de la Religion Naturelle, Paris, (1797, W ed.), pp. 3 e 11 . necessário esmagar com o tremendo peso do desprezo os materialistas, os ateus e os egoístas. É fundamental desterrar esse tipo de moral anti-social e sacrílega. E, por último, desterrar todas as opiniões abusivas desses seres comprometidos com as rotinas de seus antepassados.

Depois de estabelecer esses objetivos, Pithou de Loinville passa a expor as bases de uma teologia deísta segundo os argumentos clássicos da religião natural: a criação, as maravilhas de sua ordem e a imponência de seus enigmas. Deve-se considerar que o conhecimento da Criação é a virtude básica, é a fé da religião natural. Por essa razão, os prosélitos dessa doutrina enfatizam, como Pithou, ${ }^{2}$ a importância de uma educação atenta ao estudo da natureza, chegando a considerar o Ser Supremo como o "arquiteto sublime", conceito comum a todos os deísmos naturalistas. É nessa linha de argumentação que Pithou opõe o "altar da natureza" ao "altar do clero". ${ }^{3}$

O que é considerado mais execrável na Religião católica são os seus ministros, papel igualmente abominável em qualquer religião (e não se deve esquecer que a teofilantropia também teve uma espécie de ministros ou pregadores formais de seu culto $)^{4}$ :

Efetivamente, tudo que pode receber a denominação de sacerdócio, não importa como se chame em cada caso, possui um espírito comum de sedução apesar de seus meios divergentes.

Por toda parte derrubaram a Religião Natural, substituindo-a por outra de sua invenção.

Aquela era bela demais, queria virtudes em lugar de cerimônias. Aquela era simples demais, queria apenas virtudes em lugar de cerimônias.

Aquela era tão simples que nos dispensava de seu ministério; mas era preciso - que vergonha! -, era preciso, e ainda é, que haja intermediários entre o céu e a terra.

Foram os sacerdotes os primeiros a afirmar que o homem nasce criminoso e que convém purificá-lo dos pecados de seus pais. Eles

\footnotetext{
${ }^{2}$ Idem, pp. 58-59.

${ }^{3}$ Idem, pp. $45-46$

${ }^{4}$ Idem, pp. 33-34.
} 
mesmos lhe atribuíram inclinações más e, com o pretexto de corrigilas, puderam seduzi-lo melhor. Na verdade, chegaram a governá-lo como donos e senhores de sua alma, declarando terem recebido do céu essa missão; em suma, todos os vícios e todos os crimes contribuíram para a origem do sacerdócio; sua vida foi um entrelaçamento de todos eles e o infortúnio humano foi seu resultado. Há que reconhecer, para maior desgraça da terra, que tais foram a origem, a vida e os costumes dos sacerdotes.

A grandeza da religião natural se opõe dessa maneira à mesquinhez da religião administrada": "Olha quão grande e admirável é o homem, quando ouvindo unicamente os conselhos de seu coração e de sua alma é o que deve ser! Quão sublime ele é ao elevar-se até seu autor numa contemplação religiosa isenta de intermediários! E quão abjeto, desprezível e cheio de baixeza fica o homem quando se dispõe a submeter suas faculdades naturais a seres absurdos e amiúde criminosos!"

A divindade também é respeitada pelo discurso anticatólico, antiprotestante e antijudeu de Lambert-Lequinio; ${ }^{6}$ seus oponentes, no entanto - sobretudo Robespierre - acusam-no (a Lequinio) de ateu desmoralizador.

Cidadãos, vou demonstrar-vos que em princípio todos os cultos são claras imposturas que aviltam o homem e a divindade; não vos provarei por meio da filosofia, não a conheço, mas unicamente com as luzes da razão. Depois provarei que apenas com a moral, bem compreendida e livre de toda superstição, é possível obter-se uma boa conduta, e que a maneira de honrar o eterno é fazer o bem a seus semelhantes: tal é, cidadãos, o objetivo de meu discurso.

A grande sede da moral e da máxima felicidade em vida é o matrimônio. Por isso, se a melhor maneira de honrar o "eterno" é amando ao próximo, a mesma máxima cristã propõe a união sagrada dos esposos como paradigma da moral secular. Paradigma de amor e liberdade:

Agora vamos considerar, cidadãos, a mais interessante das satisfações, a que promove a felicidade em todos os sentidos; e,

${ }^{5}$ Idem, p. 47.

${ }^{6}$ LAMBERT, A., e KERBLA Y, Lequinio de, Discours de morale, prononcé le 2ème décadi, 20 frimaire, l'an 2ème de la république une et indívisible, au temple de la Vérité. Paris, 1793. ademais, é um dos deveres da moral, e o mais simples e agradável de cumprir. Ó vínculo sagrado dos esposos! Quando penso em vós, minha alma se eleva e se enche de amor; nunca pronunciei vosso nome sem prazer. De fato, cidadãos, graças a nossos legisladores, jamais a união conjugal foi satisfeita com tanta felicidade como em nossos dias; os padres cruéis já não têm o direito de controlar os corações, de unir as pessoas que a antipatia afasta, que se sentem cheias de aversão e ódio recíprocos; já não têm o direito de pôr no claustro uma filha que, amando um jovem que o amor formou para ela, não quer desposar um velho cadáver cujos passos vacilantes só o aproximam da tumba. Ao contrário, unidos por sua própria escolha, é com seu desejo formal que os esposos juram partilhar seus dias. Dessa maneira, a lei do divórcio será quase inútil; só existirão casais felizes...

Cessai, múmias de batina, de falar-nos de uma felicidade distante, através dos espinhos e dos sarçais que vós mesmos forjastes. O céu está perto de nós; encontra-se na prática da moral, no exercício dos direitos do homem e da natureza: pai, esposo, filhos, estes são os nossos deveres e nossos prazeres, não desejamos outros, seria caro demais obtê-los à custa da humanidade... Longe de nós os egoístas, os açambarcadores bárbaros que estão dispostos a basear sua satisfação na desgraça de seus semelhantes; que sejam para sempre aniquilados com os padres e os déspotas...

Essa moral humanista, ligeiramente deísta, que enaltece os papéis da reprodução social e reprime os vícios mais típicos do capitalismo, é a que Lambert-Lequinio preconiza como sendo a dos verdadeiros sans-culottes. O enaltecimento do matrimônio e da família (maternidade, paternidade, fraternidade) será a maior originalidade moral do deísmo patriótico e republicano do período robespierrista da Convenção. Embora no início tenha tido uma formulação menos comprometida com o deísmo e o republicanismo, logo se combinaria com eles e, ademais, curiosamente, coincidiria com os pilares da nova moral conservadora pós-revolucionária.

A Providência como explicação e ao mesmo tempo sacralização da Revolução seria outro recurso para limitar o ateísmo da Revolução. É por esse motivo que nos discursos mais populares não se pode deixar de tratar a fortaleza da Revolução Francesa como fato providencial. Assim, se já não se quer fazer apelo ao Deus cristão ou deísta, ao menos se apela à liberdade 
ou à razão em termos não menos providencialistas em mais de uma ocasião ${ }^{7}$ :

... as piras devoradoras do maquiavelismo consumiam sem cessar nossos esforços generosos: aqui, latifundiários, grandes fornecedores açambarcavam o trigo no intuito de exaurir o povo e se enriquecer; ali, padres hipócritas e anticristos agitavam os archotes incendiários do fanatismo; e, por toda parte, os homens de estado, combinados com os departamentos, urdiam secretos complôs a favor do federalismo desorganizador; fabricantes de falsos soldos, tentavam desacreditar a moeda nacional; em suma, tudo que a maldade pode imaginar de horroroso era arquitetado e praticado. Mas a divindade tutelar e querida dos franceses, coberta com um escudo impenetrável, nossa santa Liberdade, nesses momentos de crise, acompanhada por seu poderoso gênio, colocada nos píncaros de uma majestosa montanha, percorrendo com o olhar penetrante e veloz o solo da República, prodigalizava por toda parte as centelhas da verdade...

É o versátil Boissy d'Anglas, esteio das festas nacionais robespierristas, amigo das finanças e da restauração, eleito pelo terceiro estado e nomeado par de França por Luís XVIII, que nos descreve com grande acerto o balanço do debate sobre a liberdade de cultos ${ }^{8}$ :

Não se trata simplesmente de examinar se aos homens é necessária uma religião, se quando podem guiar-se pelas luzes da razão e unirse uns aos outros apenas por meio dos laços do interesse comum, dos princípios da organização social e desse sentimento imperioso que os leva a aproximar-se e a amar-se, ainda é preciso criar-lhes ilusões, ou deixar que opiniões errôneas se transformem em regras de sua conduta ou em princípio de suas relações: cabe ao tempo e à experiência instruí-los sobre essa questão; cabe à filosofia esclarecer a espécie humana e extirpar da terra os velhos erros que a dominaram. Ah! Se aos homens é necessária uma religião, se a origem de seus deveres deve ser encontrada em opiniões sobrenaturais, se os erros religiosos foram para a humanidade o fundamento de alguma vantagem, é-me impossível, pousando meu olhar no decorrer dos séculos, não me sentir dolorosamente

${ }^{7}$ PASSOT, Aristide, Discours prononcé dans le Temple de La Raison et à la Société des Sans-culottes de Nevers..., (1793), p. 2

${ }^{8}$ D'ANGLAS, Boissy, Rapport sur ta liberté des cultes, fait au nom des Comités de Salut Public, de Sûreté générale et de Légistation..., Paris, 1795, pp. 6, 8, 9, 11 e 13. comovido pelos males horrorosos que tiveram a religião por origem ou pretexto. A religião vendeu a preço muito alto os consolos que propiciou aos humanos... Uma moral doce e benfazeja envolvia às vezes o absurdo de seus dogmas e a atrocidade de sua política; um brilho imponente e sedutor mesclava-se à puerilidade de suas práticas; as abstinências ordenadas só serviam para espicaçar o amorpróprio, e algumas ilusões às vezes comovedoras ofereciam alimento à sensibilidade, esperança à desdita...

Boissy d'Anglas relaciona, igualmente, os idiomas minoritários, os costumes locais e a persistência do culto católico retrógrado:

...a barbárie de alguns idiomas que conservam a ignorância em algumas regiões da República, os encantos do costume de que algumas almas preguiçosas são incapazes de se livrar, a influência sempre poderosa das primeiras impressões da alma que se refletem com tanta força sobre todo o resto da vida e, mais do que tudo, uma funesta perseguição dirigida por homens ferozes contra homens extraviados, ajudaram a reanimar em muitos lugares o fervor de um culto em extinção..

Boissy d'Anglas critica, por outro lado, a perseguição realizada por Hébert e Chaumette em nome do ateísmo republicano. E acaba se aproximando da proposta de Robespierre sem dar-lhe seu beneplácito, mas invocando a liberdade de culto:

O homem deseja ilusões e quimeras. Sob um governo opressor, que cada instante aflige seu pensamento, sente a necessidade de procurar longe de si mesmo os consolos que não pode encontrar no que o rodeia; necessita de uma autoridade suprema, acima da autoridade que o fustiga. Sena o mais desgraçado dos seres se, quando está oprimido na terra, não esperasse um vingador no céu; e esse sentimento é o criador de todos os erros religiosos. Só o homem verdadeiramente livre goza da independência e da plenitude de sua razão. O segredo do governo em matéria de religião certamente está nestas palavras: Quereis destruir o fanatismo e a superstição, oferece ao homem uma ilustração; quereis vê-lo disposto a receber essa ilustração, sabei fazê-lo livre e feliz .... Mas, enfim, as práticas religiosas podem também ser exercidas; elas não constituem delitos contra a sociedade". Seu relatório do Comitê de Salvação Pública, de Segurança Geral e de Legislação termina recomendando evitar as provocações às práticas religiosas - evitando martirológios e 
apologias -, considerar a religião como uma opinião privada e vigiar apenas as consequências políticas e morais dos cultos.

Esse relatório deu lugar ao decreto sobre liberdade de culto de 21 de fevereiro (3 do ventoso) de 1795.

\section{O calendário republicano}

Estamos diante de outra iniciativa do progresso ateu, mas que precisamente para seu próprio realce não hesita em se utilizar desde o início das vantagens da linguagem providencialista e sacralizadora da Religião. Os redatores de Révolutions de Paris $^{1}$ julgaram com toques de predestinação, providencialismo e ordem cósmica o advento temporal da República, que seria tomado como começo cronológico do novo calendário. Do tropel de exaltações cândidas, políticas e profundas da Revolução, destaca-se este texto:

O Comitê de Instrução Pública consulta neste momento a Academia de Ciências para fazer o nosso novo regime político coincidir com o sistema planetário, e para obter um novo calendário. Os sábios já calculam, computam e esforçam-se denodadamente, como antes já acontecera, para fazer coincidir as épocas religiosas com os fenômenos astronômicos; e alguns de nossos deputados já parecem temer a vergonha e as consequências dessa inovação, como se a república francesa devesse temer abordar uma reforma que Júlio César e um papa não temeram empreender e concluíram com sucesso.

Mas graças a uma coincidência das mais felizes, o trabalho que nossos legisladores pediram aos astrônomos já parece resolvido de antemão. Não entramos na república em 21 de setembro? Pois esta data vem a ser o ponto equinocial do outono, designado pelo signo do zodíaco que justamente cai nesse mês, ou seja, a Balança, símbolo da igualdade. Quem nos impediria portanto de começar a partir de agora os nossos anos em 21 de setembro? Este limite, fácil de apreender, não atrapalha em nada a divisão em épocas da história dos diferentes povos, e não gerará nenhum caos na cronologia ou na ordem civil. Será suficiente, para coincidir com as épocas das demais nações, subtrair os nove primeiros meses do ano de 1792.

Que belo tema de horoscopia para um astrólogo, se agora ainda fosse correto sê-lo! Feliz França! Exclamaria o sol, no signo de Balança, entrando no ponto equinocial do outono quando juravas a igualdade e 
fundavas a república; reinava nesse momento uma concordância perfeita entre o céu e a terra; sob esses belos auspícios anatematizavas a realeza e davas à liberdade, para sua fortaleza, a santa e eterna igualdade, que o sol então também estabelece entre os dias e as noites. República dos francos, estão pois os teus altos destinos escritos no próprio livro da natureza? Nação poderosa e afortunada entre todas as demais, todos os anos, no mesmo dia, em 21 de setembro, encontrarás o sol no signo da Balança! Sem dúvida, esse astro que faz os dias e as noites, que duas vezes os divide por igual, encontrar-te-á fiel a partir de agora, como ele, aos deveres e aos direitos que juraste cumprir e defender. Franceses!, lembrai-vos de que vossa república nasceu sob o signo da igualdade!

Renouvier glosaria assim o advento do novo calendário:

A mais alta fórmula do novo culto apareceu no admirável Calendário Republicano, promulgado pela Convenção em dois prazos, segundo os relatórios de Romme e de Fabre d'Églantine... A nova era adotava como característica sagrada e religiosa, tal como demonstrava o austero convencional, a coincidência impressionante, e talvez única na história, de que seu ponto de partida, 22 de setembro de 1792, dia da proclamação da República, também era o equinócio de outono.

Renouvier prossegue enumerando os emblemas dos dias, das décadas e dos meses, emblemas que finalmente não foram aplicados ao calendário republicano.

O Nível, símbolo da igualdade; o Boné frígio, dos escravos libertos, símbolo da liberdade; o Cocar (cocarde), ou as cores nacionais; o Pique, arma do homem livre; o Arado, instrumento da força agrícola; o Compasso, instrumento das forças industriais; o Feixe, símbolo da força que nasce da união; o Canhão, instrumento das vitórias; o Carvalho, emblema da procriação e símbolo das virtudes sociais. Os meses receberam também uma consagração patriótica e filosófica: a Regeneração, a Confederação, o Jeu de Paume, a Bastilha, o Povo, a Montanha (localização dos jacobinos na Convenção), a República, a Unidade, a Fraternidade, a Liberdade, a Justiça, a Igualdade...

${ }^{2}$ RENOUVIER, J., Histoire de l'Art pendant la Révolution, Paris, 1863, p. 392.
Fabre d'Églalltine, ${ }^{3}$ poeta e dramaturgo natural de Carcassone admirado por Stendhal, vai elaborar, a partir da proposta do matemático Romme, o famoso Calendário Republicano, sob uma perspectiva ruralista e bucólica. Parece que Fabre, chegado à Revolução, como tantos de seus protagonistas, em torno dos quarenta anos, não escapou nem ao turbilhão dos vícios da nova corte revolucionária, nem dos castigos que Robespierre lhe infligiu enquanto pôde. Acusado de conivência com as finanças e a corrupção, não deixa de chamar ironicamente a atenção o fato de a antiga casa em que nasceu ter-se transformado, hoje em dia, numa firma financeira.

Fabre d'Églantine nos expõe o novo calendário com ingredientes que parecem proceder mais do ruralismo e da voluptuosidade climática de um nativo do Languedoc, seduzido pela terra e pelo mundo, que do racionalismo e da exaltação parisienses, mais próximos da desconfiança e da pomposidade.

Quando, em cada instante do ano, do mês, da década e do dia, o pensamento e o olhar do cidadão pousarem numa imagem da agricultura, num dom da natureza, num objeto da economia rural, não há dúvida de que isto resultará para a nação numa valorização maior da agricultura, que cada cidadão conceberá um deleite maravilhoso pelos presentes reais e efetivos que a natureza nos oferece, os de uma natureza tangível, que se pode saborear, ao contrário do que aconteceu durante séculos, nos quais o povo se apegou aos objetos fantásticos, como ocorreu com os santos que não via nem conhecia. Mais ainda: os sacerdotes não eram capazes de dar consistência aos seus ídolos, a não ser atribuindo-lhes alguma influência direta sobre os objetos que realmente interessavam ao povo. Assim, São João era o patrono das colheitas, São Marcos, o protetor da vinha... A primeira ideia, a básica, era consagrar através do novo calendário o sistema agrícola e confrontá-lo assim com a nação inteira, marcando as épocas e as frações do ano com signos inteligíveis ou visíveis, tirados da agricultura e da economia rural.

Quanto mais pontos de apoio forem oferecidos à memória, maior será a facilidade com que ela operará: por conseguinte, imaginamos dar a

${ }^{3}$ FABRE D'ÉGLANTINE, Ph., L'Evangile des Républicains précédé du rapport sur le nouveau Calendrier, Paris, 1793. 
cada um dos meses do ano um nome característico, que expressasse a temperatura que lhe é própria, o gênero de produtos reais da terra, e ao mesmo tempo fizesse sentir a estação do ano em que transcorre.

Este último efeito é obtido por meio de quatro desinências acrescentadas a cada um dos três meses consecutivos, produzindo quatro sons, cada um dos quais indicando ao ouvinte a estação à qual se aplica.

Procuramos também tirar partido da harmonia imitativa da língua na composição e na prosódia dessas palavras e no mecanismo de suas desinências; assim, os nomes dos meses que compõem o outono têm um som grave e uma medida média, os do inverno, um som pesado e uma medida longa, os da primavera, um som alegre e uma medida breve e os do verão um som cheio de sonoridade e uma medida longa.

Assim, vejamos a etimologia dos três primeiros meses do ano, que compõem o outono. A do primeiro é tirada das vindimas, que ocorrem de setembro a outubro: este mês se chama Vendemiário. A do segundo, das névoas e brumas baixas de outubro e novembro: este mês se chama Brumário. O terceiro, do frio, às vezes seco, às vezes úmido, que reina de novembro a dezembro: este mês se chama Frimário.

O primeiro dos três meses do inverno tira sua etimologia da neve que embranquece a terra de dezembro a janeiro: este mês se chama Nivoso. O segundo, das chuvas que caem generosamente com mais abundância de janeiro a fevereiro: este mês se chama Pluvioso. O terceiro, o das pancadas de chuva e do vento que vem secar a terra de fevereiro a março, chama-se Ventoso.

O primeiro dos três meses da primavera tira sua etimologia da germinação e da subida da seiva de março a abril: este mês se chama Germinal. O segundo, do desabrochar da floresta de abril a maio: este mês se chama Floreal. O terceiro, da fecundidade risonha e da colheita nos prados de maio a junho: este mês se chama Prairial.

O primeiro mês do verão, por fim, tira sua etimologia das espigas ondulantes e das messes douradas que cobrem os campos de junho a julho: este mês se chama Messidor. O segundo, do calor solar e terrestre ao mesmo tempo, que abrasa o ar de julho até agosto: este mês se chama Termidor. $\mathrm{O}$ terceiro, dos frutos que o sol doura e amadurece de agosto a setembro: este mês se chama Frutidor.
Por outro lado, a transformação das semanas em décadas e a sucessão dos dias já não recebem esse tipo de justificativa ruralista ou poética dos meses. Acrescentam-se aos decadis (dia final de cada década) cinco ou seis dias de festa chamados de sans-culottides e dedicados à virtude, ao gênio, ao trabalho, à opinião que julga e às recompensas. ${ }^{4}$

Esse calendário - e especialmente a justificativa de Fabre - pode ser encarado como uma das melhores conquistas do ateísmo durante a Revolução, se pensarmos no desafio que ele representava frente ao calendário gregoriano. Mas em si mesmo é apenas uma peça ruralista e naturalista que combinaria perfeitamente com várias ideologias, inclusive as conservadoras. Parece, entretanto, que a primeira interpretação primou sobre a segunda, considerando-se a primazia do desafio político à Igreja. Assim interpretava-o claramente o Papa quando pedia a Napoleão o retomo ao calendário gregoriano.

Durand de Maillane, um dos artífices da Constituição Civil do Clero, partidário de sua submissão ao poder secular, e depois membro moderado e reacionário da Convenção, foi dos que interpretaram o calendário de Fabre d'Églantine como um gesto inequivocamente ateu (em suas observações retrospectivas):

A mudança de calendário foi o prelúdio da abolição do cristianismo. A Comuná veio propor esse ato de impiedade à Convenção, que se tomou cúmplice, e substituiu com um decreto o culto católico pelo culto da razão. Esse escândalo deplorável, os discursos em homenagem ao ateísmo, as abjurações indecentes, em sua maioria forçadas, figuraram nos autos que foram enviados às autoridades e aos exércitos. O poeta Chénier compôs um hino no qual, como fiel discípulo de Voltaire, declarava guerra aberta à religião de Jesus Cristo $^{5}$

\footnotetext{
${ }^{4}$ Cf. Concordance des Calendriers Grégorien et Républicain, Paris, 1983.
}

${ }^{5}$ MAILlANE, Durand de, Histoire de la Convention Nationale, Paris, 1825, pp. 180-181. 


\section{A santa guilhotina}

Sem os exageros das interpretações que de uma forma ou de outra se baseiam no fascínio anedótico e excessivamente simbólico (o culto do "imaginário" na historiografia recente), é preciso considerar o suplício instituído durante a Revolução, a guilhotina, no contexto das questões de religiosidade da época.

A guilhotina introduziu a igualdade na pena de morte, aplicada até então de acordo com a posição social dos acusados e a natureza dos crimes cometidos. Ao mesmo tempo, reduziu enormemente a maioria dos tormentos dos condenados à morte. Tormentos que seriam glosados com bárbara nostalgia por de Maistre. Foi um fabricante alemão, que se notabilizara pelo fabrico de harpas, o primeiro artífice da guilhotina, também inicialmente chamada de louison, em alusão a seu outro projetista, Antoine Louis.

Critérios morais, políticos e biológicos convergiram na implantação da guilhotina. Tratava-se de justiçar com mais compaixão pelo sofrimento alheio, com menos arrogância e crueldade. Mas o espetáculo, o sangue e os excessos da guilhotina logo suscitaram complacências, devoções e abysos indesejados por seus criadores revolucionários. Assim, os redatores de Révolutions de Paris ${ }^{1}$ se queixavam do longo trajeto que os condenados tinham de percorrer entre as prisões e o cadafalso, do comportamento das pessoas para com os condenados, do procedimento pouco digno da guarda para com as vítimas...

Os hebertistas e as correntes demagógicas logo arvoraram a guilhotina como arma cega e impiedosa da ofensiva revolucionária. Assim foi criada a visão grosseira do Terror. Não como uma pressão moral, como pretendia Robespierre, que não cessasse de dissuadir os irresponsáveis e os corruptores da Revolução, mas como um capricho horrendo em mãos de uma populaça mais ébria de sangue do que de justiça. Foi assim que surgiu a idolatria do sans-culotte, que o comando da Revolução já não conseguia controlar: "Santa Guilhotina, protetora dos patriotas/ Rogai por nós/ Santa Guilhotina, horror dos aristocratas/ Protegei-nos".

\footnotetext{
${ }^{1}$ Révolutions de Paris, $\mathrm{n}^{\circ} 218$, p. 362, e outros.
}

Citemos um texto de Révolutions de Paris $^{2}$ no intuito de esclarecer melhor a justa apreciação desse instrumento de morte a serviço da Revolução:

O sistema da guilhotina foi aperfeiçoado; não poderíamos imaginar outro instrumento de morte que conciliasse melhor o que se deve à humanidade com o que a lei exige; pelo menos enquanto a pena capital não for abolida. $\mathrm{O}$ cerimonial da execução também deveria ser aperfeiçoado, eliminando-se tudo que evoca o antigo regime (a carreta, as mãos atadas, a assistência do sacerdote).

Outra crítica que se deve fazer a esse suplício é que, embora poupe dor ao condenado, não evita a visão do sangue que o fio da guilhotina faz saltar e do que se derrama abundantemente no pavimento sob o patíbulo; esse espetáculo tão repelente não deveria ser oferecido aos olhos do povo; e seria fácil sanar esse inconveniente, posto que de outro modo serve para familiarizar as pessoas com a ação de um crime que, embora cometido em nome da lei, é de um sangue-frio que evoca a ferocidade calculada.

Por outro lado, a multidão se queixa de que esse suplício é suave demais para os maus que até agora foram executados, chegando assim. Muitos deles a mostrar uma atitude desafiadora; o povo se degrada buscando vingança ao invés de limitar-se a fazer justiça.

Restif de la Bretonne, considerando que sua sensibilidade não suportaria o espetáculo da guilhotina, imaginou-a assim quando as autoridades bateram à sua porta com uma convocação judicial para sua exmulher ${ }^{3}$ :

Minha fogosa imaginação, que me causa tantas desditas durante as noites, minha imaginação vagabunda me fazia ver a audiência revolucionária. Dumas e Coffinhal (presidente e vice-presidente do tribunal), seus sicários, os bancos, os guardas com a baioneta calada, o fulminante 'Não tens a palavra!', o estremecedor corte do cabelo, as mãos horrivelmente atadas às costas, a carreta, os gritos desenfreados da populaça, a descida que aperta o coração, a escada

\footnotetext{
${ }^{2}$ Idem, no 198, 20-27 de IV, 1793, p. 224.

${ }^{3}$ RESTIF DE LA BRETONNE, N.E., Les nuits révolutionnaires (F. Funck-Brentano ed.) (1910?), p. 29.
} 
fatal, a inclinação sobre a prancha, a queda ruidosa da lâmina, as torrentes de sangue.

Mas, como se sabe, a guilhotina também se tornou um espetáculo ainda mais interessante que a maioria dos proporcionados pelas execuções do antigo regime, o que é fácil de entender sabendo-se que foram executados um rei, uma rainha, princesas e aristocratas, diante de espectadores que, poucos anos antes, mal podiam imaginar a possibilidade desses acontecimentos; que foram executados jovens como Charlotte Corday ou Cécile Renault, a que "quis ver um tirano de perto", suscitando admiração e exaltação; que muitas execuções decorriam de vinganças e ambições pessoais pouco relacionadas com as ideologias e suas realizações; e que inspiravam a morbidez e a baixeza dos espectadores e testemunhas. Não foi exatamente o terror que congregou a multidão em tomo do cadafalso, mas a conivência com os ajustes de contas, o desejo de ver de perto vítimas desconhecidas, de ver o sofrimento irremediável, de assistir a algo importante e forte, de assistir talvez a um milagre...

A mais comentada das execuções foi sem dúvida a do rei. Nela ficou patente a devoção monárquica de parte da população, observada inclusive por seus mais acerbos inimigos. ${ }^{4}$ Gestos, símbolos, emoção, esperanças, patetismo, impotência e, finalmente, desengano, desespero e rotina foram experimentados e expressos pelos monarquistas parisienses, ante o 'suplício de seu rei. As mulheres mostraram-se como as mais devotas da monarquia e as mais necessitadas da redenção dos regicidas, dos novos pigmaliões revolucionários ${ }^{5}$ :

Os padres e seus devotos, que já estão procurando um lugar em seu calendário para Luís XVI, um lugar entre os mártires, compararam

${ }^{4}$ Révolutions de Paris, $\mathrm{n}^{\circ} 185,19-26$ de I, 1793. As heroínas que mais se destacaram no cadafalso parisiense foram Charlotte Corday, assassina de Marat e por conseguinte idolatrada por Adam Lux; Mme. Roland, esposa do ministro Roland, célebre por sua lucidez e perspicácia no trato humano; Cécile Renault, a que "quis ver o tirano de perto"; Mme. du Barry, a aristocrata por excelência; Olympe de Gouges, preocupada com a situação da mulher durante a Revolução e que "propôs" a Robespierre que ambos se atirassem juntos no Sena para "livrar o país do pior flagelo"; Maria Antonieta e sua cunhada, a irmã do rei. Outra vítima aristocrata, famosa por seu suplício, foi a princesa de Lamballe. Pereceu no massacre de setembro, esquartejada e despedaçada, sua cabeça foi exibida ao rei no topo de uma lança diante de sua janela na prisão do Templo.

Idem, pp. 204 e 207. sua execução à paixão de seu Cristo. Assim como o povo judeu de Jerusalém, o povo de Paris teria rasgado ao meio a levita de Luís Capeto, scinderunt vestimenta sua, e cada qual quis guardar um pedaço... As mulheres, de quem não devemos, e com razão, exigir que estejam imediatamente à altura dos acontecimentos políticos, mostraram-se em geral bastante tristes; o que ainda mais contribuiu para aumentar a atmosfera melancólica que reinou em Paris o dia todo. ${ }^{6}$ Houve, talvez, mais de uma lágrima vertida; mas já se sabe que as mulheres não são avarentas para isso. Houve também algumas censuras, inclusive algumas injúrias. Tudo isto é perdoável a um sexo cheio de leviandades e fragilidades, que viu luzir os últimos belos dias de uma corte brilhante. As mulheres sentirão algum pesar ao deixar o reino da galanteria e do luxo para enveredar pelo império dos costumes simples e austeros da república; mas se acostumarão a ver-se menos escravas, mais honradas e mais amadas do que antes.

A devoção monárquica forçou os regicidas a interpretarem até a execução de Luís XVI como um sacrifício ritual: "A liberdade se parece com aquela divindade dos antigos a quem não era possível propiciar nem tomá-la a seu favor sem oferecer em sacrifício a vida de um grande culpado"?

A manifestação da divindade do povo, da excelência de sua vingança, foi glosada por ocasião das matanças de setembro de 1792. Partindo do princípio de que realmente existia uma conspiração contrarrevolucionária nas prisões, com a intenção de aliar-se às tropas estrangeiras que estavam avançando em direção a Paris, a matança é relatada como um ato providencial do povo ${ }^{8}$ :

O povo que, como Deus, tudo vê, está presente em toda parte, e sem o consentimento do qual nada ocorre aqui embaixo, uma vez tendo tomado conhecimento dessa conspiração infernal, optou por uma decisão extrema, mas a única que convinha: a de prevenir os horrores que lhe estavam sendo preparados e mostrar-se sem misericórdia para com as pessoas que não teriam tido nenhuma com ele.

${ }^{6}$ Não houve concordância sobre essa opinião. Vários autores garantem que Paris continuou animada como de costume, especialmente à noite.

${ }^{7}$ Ibid., p. 207.

${ }^{8}$ Révolutions de Paris, $\mathrm{n}^{\circ} 165$, p. 419. 
Neste mesmo espírito é justificada a fúria popular contra a aristocracia, dando a entender que só a destruição carregada de fúria seria a única resposta honesta à provocação e ao despeito soberbos dos que, depois de reduzir o povo à miséria, escarneciam dele, menosprezavam-nos, demonstrando indiferença e superioridade, ameaçando-os ainda mais. Assim se justifica a represália contra a princesa de Lamballe, protótipo da dama da corte ignorante e desafiadora das aspirações do povo, arrogante ante a autoridade moral de homens que para uma cortesã nada mais são do que a canalha:

A Lamballe, citada perante o tribunal do povo, comparece com esse ar insolente que antes tinham as damas da corte, mas que não é apropriado para uma criminosa que comparece perante o juiz: e pretende-se que o povo não perca a paciência!

Mas nos extremos do castigo que a nova república infligia, encontramos também, como no antigo regime, os desatinos do despotismo singular, infelizmente anedóticos, reais e ordinários. Carrier os exemplificou':

Com seus olhos lascivos e sanguinolentos, devora a nudez (pessoas de sexos diferentes eram amarradas, aos pares, inteiramente nuas e de frente como numa cópula) de suas vítimas, que ousa acoplar na morte, querendo sem dúvida ultrajar duplamente a natureza, oferecendo-lhe, no espetáculo da destruição, também o da reprodução dos seres: Carrier denominava este tipo de afogamento "fazer matrimônios republicanos.

Em alguns casos o terror foi interpretado como um extermínio em massa de tudo o que era considerado "raça não-republicana". Por essa razão, alguns concordavam que se devesse assassinar também as crianças, em virtude dos estigmas de sua raça. Por isto, somando-se a ideia de que o crescimento populacional na França seria a causa de seus males, tema recriado por Sade em sua Nouvelle Justine, atribuiu-se a um setor do Terror uma missão que, em termos atuais, poderia ser qualificada de genocídio, embora concebido parcial e minoritariamente e sem o apoio da Convenção Nacional.

${ }^{9}$ Collection Complète des Tableaux historiques de La Révolution Française, Paris, 1804,93 tab., p. 375. Noyades dans II Loire: 26-27, XII, 1793.

\section{Sade: $O$ antiteísmo}

Se o esforço da maioria dos filósofos ateus visava provar a compatibilidade (e até mesmo o casamento insuperável) entre a virtude e o ateísmo, Sade as desvincula, na certeza absoluta de que o ateísmo combina melhor com a virtude desamparada. A leitura atenta da obra de Sade pode mostrar como a argumentação ateia na boca dos libertinos adquire sentido ante o desamparo da virtude, não ante o vício por si mesmo, o que nos leva a considerar o antiteísmo de Sade: seu ateísmo decorre da indiferença da suposta providência para com a virtude oprimida, para com as ciladas da natureza invencível e para com a irrefreável força da material idade na vida. Se Deus existe, é tão mau e indiferente quanto a natureza. Sade não toma a ideia de Deus sem sentido como um verdadeiro ateu, mas luta contra ela em sentido negativo, antiteísta:

Ah! Se existisse um Deus a quem o crime ofendesse, seria possível que ele desse ao homem todos os meios para cometê-lo? Que digo!, se o crime ofendesse a este pretenso autor da natureza, seria ele então essencial para as leis da natureza? Pensa portanto que essa natureza depravada só se alimenta de crimes, só eles a sustentam; e que se os crimes são necessários, não podem ultrajar a natureza nem o ser imaginário que supões ser o seu motor. ${ }^{1}$

Se a natureza se encarniça contra o homem, este deve imitá-la e quem sabe, assim como à ideia de Deus - o antiteísmo corresponde a um antinaturalismo -, o homem deve desprezá-la e ainda que seja impossível, procurar aniquilá-la:

Imitá-la-ei, mas detestando-a; copiá-la-ei, já que a natureza assim o quer, mas amaldiçoando-a; e, furioso ao ver que minhas paixões servem-na, descobrirei seus segredos até poder, se isto me for possível, chegar a ser ainda mais malvado para melhor ofendê-la.

"A impossibilidade de ultrajar a natureza é o grande suplício do homem". Sade não fica satisfeito com a submissão às "inclinações naturais" e nos revela sua rebeldia contra a própria natureza que, por outro lado, parece elogiar.

${ }^{1}$ SADE, D.A.F., La Nouvelle Justine, 2 V., Paris, 1978, pp. 297-298, 459 e 481. 
Seu imperativo moral excede seu absolutismo natural e niilista. Sade é, acima de tudo, um rebelde contra a natureza e contra sua absoluta irresponsabilidade, Deus.

O antiteísmo de Sade é mais forte do que seu ateísmo. Por esse motivo, critica e insulta a Deus incessantemente, apesar de negar sua existência. Na verdade, Sade encontra na Bíblia a prova da existência de qualidades perversas em Deus. Assim, escolhe o ateísmo por motivos morais. Um de seus personagens chega a dizer nesse sentido:

"Quando o ateísmo quiser mártires, que o diga, meu sangue estará a sua disposição. ${ }^{2}$

"Sempre foi na forja da tristeza e do espanto que o homem desgraçado criou o fantasma ridículo que fez o seu Deus". A doutrina ateia de Sade não possui maior originalidade que a dos filósofos seus antecessores. Entretanto, sua argumentação é muito mais antiteísta do que a deles, no sentido de apresentar o ateísmo como uma opinião saudável depois do rigor do antiteísmo moral. ${ }^{3}$

Em Dialogue entre un prêtre et un moribond, Sade parece seguir ao pé da letra os argumentos de d'Holbach. A conclusão melhor ou mais abertamente expressa na obra de Sade talvez seja a de que o nada ofende menos a razão humana que viveu do que a promessa da imortalidade.

Sade tem clara consciência de sua argumentação antiteísta e procura reduzir a uma explicação natural, d'holbachiana, sua necessidade de considerar Deus, ainda que seja para negá-lo imediatamente:

nossas percepções, nossos órgãos, de uma natureza mais delicada que os dos animais, nos levaram a crer na existência de Deus e na imortalidade da alma... Que melhor prova da verdade de todas estas coisas do que a própria necessidade de admiti-las! Eis aqui precisamente em que consiste o sofisma. Com certeza a constituição que nos foi dada pela natureza nos obriga a criar quimeras e a nos consolar com elas...

\footnotetext{
${ }^{2}$ Idem, vol. I, pp. 133-139.
}

${ }^{3}$ Idem, vol. I, pp. 83, 94 e 95; vol. II, pp. 668-673; vol. I, pp. 244-247.

${ }^{4}$ Idem, vol. II, pp. 548-549.
Essa fraqueza é indigna aos olhos de Sade e, assim: “é mil vezes mais agradável para o homem depender de uma natureza cega do que de um ser cujas boas qualidades, só afirmadas pelos teólogos, são constantemente desmentidas pelos fatos". Desse modo, a escolha do acaso natural procede de um juízo antiteológico. Sade chega ao ateísmo materialista através do antiteísmo moral. Sem este último, a seu ver, o primeiro não adquire pleno sentido.

A queda de Justine é a que dá mais sentido à argumentação materialista de Sade com vistas a provar a não existência de Deus: "Ó, Providência!, explica-me teus decretos incompreensíveis se não quiseres que meu coração se rebele". moral:

O ateísmo de Sade desprende-se incessantemente de seu antiteísmo

Se Deus existisse, haveria menos mal sobre a terra. Então, se esse mal existe, ou ele é ordenado por Deus, e assim nos encontramos ante um ser bárbaro, ou ele não é capaz de impedi-lo, com o que temos um Deus fraco; em qualquer caso, estamos falando de um ser abominável, um ser que devo desafiar e desprezar. Ah, Justine, não vale mais o ateísmo que qualquer destes extremos?

O egoísmo, segundo dizem, é a base de todas as ações humanas; nenhuma, dizem, carece do interesse pessoal como primeiro motivo e, baseando-se nessa cruel opinião, os terríveis detratores de todas as belas ações reduzem o seu mérito a nada. Ó, Marat! Como tuas ações sublimes te subtraem a essa lei geral! Que motivo de pessoal interesse afastava-te do convívio dos homens, privava-te de todas as amenidades da vida, relegava-te vivo a uma espécie de túmulo? Que outro motivo senão o de iluminar teus semelhantes e assegurar a felicidade de teus irmãos? O que te conferia a coragem de tudo desafiar... até os próprios exércitos dirigidos contra ti, se não o desinteresse mais completo, o mais puro amor ao povo, o civismo mais ardente do qual nos deste o exemplo!

Escévulus, Brutus, vosso único mérito consistiu em armar-vos por um instante para acabar com os dias do despotismo, vosso patriotismo brilhou pelo menos durante uma hora; mas tu, Marat, por

\footnotetext{
${ }^{5}$ Idem, vol. II, pp. 571 e 800.
} 
que caminho tão difícil palmilhaste a senda do homem livre, quantos espinhos não se interpuseram em tua estrada antes de chegares à meta, porque nos falavas da liberdade rodeado de tiranos pouco acostumados ao nome sagrado desta Deusa, tu já a adoravas antes de a conhecermos; os punhais maquiavélicos cercavam tua cabeça sem que tua fronte se sentisse alterada; Escévulus e Brutus ameaçaram seus respectivos tiranos, mas tua alma, ainda maior, quis imolar a todos os que sobrecarregavam a terra, e os escravos chegavam a acusar-te de querer o sangue! Grande homem, era o sangue dessa escória que querias derramar; e se te mostravas pródigo em tal derramamento era para poupar o do povo; com tantos inimigos, como não sucumbirias? A ti, que revelavas os traidores, a traição assassinaria.

Sexo tímido e doce, como é possível que tuas delicadas mãos tenham segurado o punhal que a sedução afiava? Ah, vossa pressa em chegar à tumba e enfeitá-la de flores, a tumba do verdadeiro amigo do povo, fazei-nos esquecer que o crime pode encontrar um braço entre vós. O bárbaro assassino de Marat, semelhante a esses seres mistos aos quais não se pode atribuir nenhum sexo, vomitado pelo mesmo inferno para desespero de ambos, não pertence a nenhum diretamente. Uma tela fúnebre sepultará sua memória para sempre; que parem de apresentar-nos esse ser, como ousam fazê-lo, com sua efígie sob o emblema encantador da beleza. Artistas crédulos demais, rasgai, derrubai, desfigurai as feições desse monstro, ou só o oferecei ante nossos olhos em meio às fúrias do Tártaro. ${ }^{6}$

Assim Sade se despede de Marat. Evidencia-se uma clara inversão de valores em seu discurso quando o comparamos ao romance gerado durante o período revolucionário: condenação da teoria fatalista do egoísmo; elogio da política laboriosa e obscura do herói honesto, da generosidade para com um povo que necessita de ajuda, da justiça valente e tenaz; elogio do sacrifício e condenação da traição criminosa; consideração para com as mulheres e negação de sua condição ante ações insensatas.

Única Deusa dos franceses, santa e divina Liberdade, permite que aos pés de teus altares derramemos mais algumas lágrimas pela perda de teus dois fiéis amigos (Marat e Le Pelletier)... Agora os vejo sorrir

${ }^{6}$ SADE, D.A.F., Section des Piques. Discours prononcé à la Fête décernée par la Section des Piques, aux mânes de Marat et de Le Pelletier, 29-IX-1793. diante do culto que nosso civismo lhes oferece as Nações invejarão a honra de serem aliadas do povo francês; substituindo o frívolo mérito de oferecer aos estrangeiros nossas modas e costumes, daremos ao mundo assombrado novas leis, exemplos, virtudes e homens. E se algum dia os países mergulharem em transtornos e fatalidades, confundindo-se e extraviando-se, a imortal Deusa que veneramos, zelosa em mostrar às raças futuras a parte habitada pelo povo que melhor a serviu, indicaria a França como exemplo para os novos homens que a natureza tivesse recriado.

A França no destino das nações, no cultivo da razão e da virtude, na fé e na firmeza patrióticas substituindo a frivolidade e a afetação que lhes são imputadas: Sade articula corretamente a ordem oposta ao seu discurso lítero-filosófico. Assim, este pode ser interpretado como caricatura de uma cultura e de uma civilização "demasiado humanas", no dizer de Nietzsche: Justine e Juliette seriam o Quixote e o Sancho Pança do humanismo, que não possui outras armas para lutar contra a misantropia e o niilismo além do seu endeusamento e presunção.

Sade defende em sua teatrologia, com pouquíssimo sucesso, a junção da boa fé com o despotismo e a hipocrisia reinantes, defesa aliás que despreza com sarcasmos em suas novelas revolucionárias. Parece que Sade tenta fazer um teatro convencional para obter recursos durante a Revolução, depois de seu castelo de Lacoste ter sido saqueado. Contudo, Sade já coloca no teatro boa parte da problemática que no romance não resolverá convencionalmente, procedimento partilhado por outros escritores ilustrados, como Diderot ou Voltaire: "É assombroso constatar que os escritores do século XVIII acreditavam poder atrever-se a tudo em seus romances enquanto seguiam uma moral aceita e aceitável em seu teatro".? Sade insere em seu teatro, ou se quisermos em seus romances, personagens - às vezes os mesmos - antagônicos em seus valores e atitudes. Segundo Brochier, no teatro de Sade é mais colocada a problemática de Candide ou de Zadig, mas com lampejos de um maior niilismo, como em "Fanny ou les effets du désespoir". No entanto, em peças como "L'union des arts" ou boa parte de "La coquette punie", a inocência e a virtude recebem homenagens e prêmios.

\footnotetext{
${ }^{7}$ SADE, D.A.F., Oeuvres Complètes, Paris (c.1970), vol. XXXIII, pp. 18, 21 e 30
} 
Se muitos dos personagens de seus romances revelam no teatro uma face virtuosa, os eclesiásticos, objeto da mais sistemática organização libertina em Justine e em La Nouvelle Justine, estão ausentes do teatro, como se sua representação em negativo fosse a única verdadeira, em contraste com os nobres, magistrados, filósofos, etc., tratados como objeto das maiores virtudes nas peças escritas por ele. ${ }^{8}$

Se Sade optou pelo teatro como meio de ganhar dinheiro, também optou pelo romance de fundo pornográfico-fílosófico, segundo suas próprias declarações, com o mesmo fim. Desta segunda produção cabe destacar vários títulos devido à importância atribuída à questão religiosa. $\mathrm{Na}$ prisão de Vincennes escreveu, no verão de 1782, Dialogue entre un prêtre et un moriboná, onde o ateísmo, discutindo com a providência representada pelo cristianismo, assume a forma de um diálogo agonizante. A mesma agonia é a prova dos argumentos ateus - ou melhor, antiteístas, pois Sade quase sempre critica a suposta responsabilidade de um Deus, ao invés de demonstrar sua falta de sentido - do moribundo, já que, à medida que vai perdendo suas faculdades corporais, a expressão de sua alma também fica diminuída.

Deve-se certamente ao antiteísmo acentuado de Sade, a seu confronto com um Deus irresponsável mais que com uma quimera inexistente, o fato de seu "ateísmo" desesperado - que Klossowski trata precisamente como uma fé inquieta - manter uma estreita aliança com tudo que há de mau. Se Voltaire, em suas queixas contra a Providência, optara pela resignação e por desfrutar das pequenas satisfações, Sade opta por uma rebelião permanente, que às vezes indica cinismo e às vezes puro desespero ante o poder transcendente. Esta última tendência acaba prevalecendo na obra de Sade, transformando-a numa obra com profunda preocupação religiosa. E que isto seja entendido sem pretensão alguma: Justine sofre todo o cinismo próprio da libertinagem, mas o que chega a acabar com ela é uma ação fulminante da Providência. Sade é o autor que, negando a ação de Deus sobre a terra, negando inclusive a sua existência, não se cansa jamais de atacar sua irresponsabilidade. Sade precisa de Deus e como um outro Don Juan o desafia, embora deva reunir-se a ele no inferno. ${ }^{9}$

\footnotetext{
${ }^{8}$ LELY, G., Vie du Marquis de Sade, 2 v., Paris, 1957.
}

${ }^{9}$ Idem, pp. 323-28 e 336.
O filantropismo ateu não basta a Sade. Escarnecerá dele tanto ou mais que da religião em seus romances. Se em algum momento da Revolução tentou abraçá-lo, logo a seguir o renegará como superstição enganosa e servil. Em novembro de 1793, Sade e seus companheiros se haviam referido à Razão como a Divindade mais querida e à Moral como a fonte da vida humana, mas é na Paixão e é na Libertinagem que a afirmação da transcendência e da vida terá mais sentido para a alma desesperada. Gilbert Lely atribui a essa condição de desespero espiritual o caráter inofensivo do apostolado sadiano: é o virtuoso Robespierre que mata de verdade, não esse verdugo cheio de imaginação e de bela expressão. ${ }^{10}$

Restif de la Bretonne, com sua Anti-Justine, se opôs à pregação de Sade em nome do amor: para Restif, a paixão mais forte é o amor, o amor que cultua. Se o amor fere e assassina é porque ele é fraco em si mesmo, abortado. Por isso, Restif relaciona a temática sadiana à impotência e à degeneração. Em sua Anti-Justine o amor mais socialmente condenável aparece com verdadeira paixão e sem o uso da crueldade para estimular seu gozo. Contudo, Restif não se detém com muita atenção em toda a argumentação e em toda a estrutura filosófica da obra de Sade, mas, como a maioria dos leitores vítimas de suas próprias ressonâncias psicológicas, fica preso ao comportamento "sádico". Ante esse tipo de interpretação, Sade adquire maior transcendência e obtém uma espécie de homenagem necessária à religião, a sua necessidade de Deus: Justine não pára em sua busca, nenhum amor, nem o mais puro poderia redimi-la de seus males, não atinge nem a cumplicidade libertina nem a satisfação proporcionada por um amor generoso; seu mais íntimo interlocutor é sempre Deus, a quem finalmente encontra e a quem Sade atribui o dom de matá-la sem os sofrimentos e as vexações que os humanos lhe infligem. Deus aparece finalmente não muito distante do deísmo voltairiano, eliminando talvez por compaixão o complexo de desventuras causadas pelo gênero humano.

Sade escreveu um "Tratado sobre a existência de Deus", do qual só resta o título ${ }^{11}$ e um pequeno trecho que vem confirmar sua obsessão teológica. Obsessão mais acirrada e aparentemente fora de lugar no discurso ateu do bandido-filósofo Coração de Ferro, em La Nouvelle Justine: nele

\footnotetext{
${ }^{10}$ Idem, pp. 531 e segs.

${ }^{11}$ Idem, p.631.
} 
são recapitulados os principais argumentos do ateísmo d'holbachiano e, ao mesmo tempo, são estabelecidas as reações morais típicas do antiteísmo, o pensar a existência de Deus como a má existência de alguém de quem se necessita e se necessita precisamente como bom. Sade chega a apresentar o ateísmo como a prudência resignada da mais espontânea reação antiteísta, assim como nos apresenta a morte como mais digna do que a imortalidade para todos os que conhecem a experiência da vida.

Em seu testamento de $1806,{ }^{12}$ Sade pede que não o sepultem sem a precaução de bem assegurar-se de seu estado de cadáver, que se o enterrem com austeridade num lugar que ele mesmo determina com precisão e que sejam plantadas sementes em sua fossa a fim de que não restem traços do lugar de sua tumba:

Desapareçam da superfície da terra, como pretendo que também aconteça com minha memória, que espero se apague do espírito dos homens, com exceção dos poucos que me amaram até o último momento e dos quais levo a doce lembrança à tumba.

Exceto a discrição, as demais disposições de seu testamento no que se refere à hora de sua morte não foram respeitadas. Sade foi enterrado com uma cerimônia católica em Charenton.

Quando um médico que conhecera Sade observou seu crânio depois de algum tempo, fez a seguinte observação que teria feito sorrir com deleite o autor de Les 120 journées de Sodoma:

Em suma, se nada fazia adivinhar em Sade passeando com gravidade, quase diria patriarcalmente, o autor de Justine e de Juliette, a inspeção de sua cabeça me teria feito absolvê-lo da inculpação de tais obras: seu crânio era similar em todos os aspectos ao de um padre da Igreja.

\footnotetext{
12 Idem, p. 658
}

\section{A RELIGIOSIDADE DA REVOLUÇÃo}

\section{O Panteão e as panteonizações}

A transformação do novo templo de Ste. Genevieve no Panteão dos homens ilustres confirmaria Paris ainda mais como sede da religiosidade revolucionária. O Panteão foi concebido como templo no qual "tudo será deus, exceto o próprio Deus". ${ }^{1}$

Uma religiosidade revolucionária, sem esta designação, mas com todas as precauções para não contaminá-la de religiosidade católica, já havia sido cogitada pelos primeiros líderes da Revolução, como Mirabeau:

Vossas festas não serão em absoluto religiosas; não é que a religião as censure ou proscreva: ela mesma se adorna com sua pompa; mas quando a religião já não é o objetivo principal, quando as impressões que traz à alma não devem ser as dominantes, não é conveniente que apareça; é mais religioso mantê-la afastada. ${ }^{2}$

Quatremere de Quincy harmonizou-se perfeitamente com o ideal artístico da Revolução em sua concepção do novo Panteão francês, apesar de sua defecção política, que em breve se acentuariaª

A pátria é uma divindade nova para um povo livre; mas seu culto não conhece o sectarismo. Limitada ao exercício de todas as virtudes cujo ponto de apoio está na terra, essa religião não rivaliza de forma alguma com a que detém as recompensas e as profecias descidas do céu, não julga suas leis nem partilha seus templos, mas deseja ter um altar ao redor do qual seus cultuadores contraiam o laço da fraternidade e que não conheça nenhum direito de primogenitura nem de predileção, nem signos distintivos.

${ }^{1}$ Df. ROBINET, Le Mouvement Religieux à Paris pendant la Révolution, Paris, 1896, t.I., p. 540.

${ }_{2}^{2}$ Idem, p. 508. Mirabeau e seu amigo Cabanis haviam elaborado um vasto projeto de cultura cívica, cf. Robinet, op. cit., pp. 509-510.

${ }^{3}$ QUATREMERE, A., Premier Rapport présenté au directoire dans le mois de Mai 1791, sur les mesures propes à tranformer l'Église dite de Sainte-Geneviève en Panthéon Français, Paris, 1792, p. 5. 
É sobretudo nas homenagens que a Pátria presta aos grandes homens, é nesse reconhecimento das boas obras, que a Pátria não é senão mãe comum de todos os seus filhos. Seus abraços enlaçam a todos por igual, e ficaria aflita com tudo que pudesse se interpor à expressão de seu reconhecimento a todos os que estão unidos pelo mesmo amor pátrio.

Essa cruel separação ocorreria entretanto, se o culto à Pátria, associado sob as mesmas abóbadas ao da Divindade, encontrasse em alguns dogmas, ou inclusive em algumas práticas religiosas, títulos ou motivos de proscrição contra algum de seus prosélitos. Quem sabe se uma aliança desse gênero poderia inclusive despertar toda a atividade dos preconceitos que uma filosofia pouco previdente acreditaria já ter aniquilado.

O contraste, e por que não dizer, o ridículo do novo destino do templo, se comparado ao que deu lugar a sua edificação, seria ainda pior se se quisesse reunir no mesmo recinto a homenagem de uma devoção mais ou menos esclarecida ao piedoso objeto de uma santa credulidade, às honras profanas e às cerimônias cívicas que a filosófica superstição do gênio dedicará às relíquias ou à memória dos grandes homens.

Quatremere conclui que o novo templo deve destinar-se exclusivamente ao culto pátrio e dos grandes homens, evitando todo conflito com qualquer outra finalidade religiosa:

O culto dos Grandes Homens, ou das Virtudes, e o da Pátria são inseparáveis nesse lugar. Não é possível honrar os efeitos sem remeter à causa. A Analogia deve então atrair para esse Templo as diversas instituições cívicas que devem compor uma Religião patriótica. Levando em conta esta consideração, era-nos necessário um templo espaçoso, claro em toda sua construção e que não ultrapassasse os limites que a natureza impõe à difusão da voz e ao alcance da vista.

Assim pois, o destino atual de nosso Monumento - devido à natureza das instituições que lhe são associadas, oferecendo uma mescla determinada de uso e características, combinando as ideias de Sepultura e Templo, de festas e de Monumentos Históricos - não combina de todo mal com os princípios já dados de antemão e que não podíamos mudar.
Depois de comentar o necessário complemento escultórico da arquitetura, Quatremere, alinhado a toda uma tradição filosófica do Iluminismo, apela para o uso da alegoria como representação mais significativa do novo monumento ${ }^{4}$ :

Foi aos Grandes Homens que a Pátria, em seu reconhecimento, dedicou este Monumento.

É também a Pátria que aparece nesse baixo-relevo como divindade principal do Templo, acompanhada dos símbolos característicos da França. Um altar ornado de festões e de signos compensadores está a seu lado. Deste altar pegou as coroas, que sustenta com os dois braços e apresenta à emulação pública. Uma delas é pousada na cabeça da Virtude. Com o seu ar tímido e seu porte modesto, o Artista quis dar a entender que a verdadeira virtude contenta-se em receber as recompensas: não sabe nem solicitá-las nem recusá-las. Mas que a Pátria sempre saberá achá-la e adverti-la. Um caráter distinto aparece com fulgor numa imagem oposta. É o Gênio, personificado por um belo jovem alado; uma clava, símbolo da força, capaz de domar todos os obstáculos, está em sua mão esquerda. Só é preciso mostrar-lhe a recompensa. Assim, sua mão direita pega coroa que a Pátria lhe oferece; sua atmosfera, sua atitude e a expressão de seu rosto anunciam sem dúvida a coragem. Esse desejo de Glória e essa ambição por recompensas são o alimento do Gênio. Se a Virtude espera a coroa, o Gênio a arranca. Tais são os principais traços que diferenciam essas duas figuras. Mas o que forma seu cortejo ou vem a seguir acentua ainda mais suas características.

Atrás da Virtude, plana no ar o Gênio da Liberdade. Com uma das mãos, segura o escudo da França; com a outra, agarra pelas jubas e conduz triunfalmente dois leões atrelados a um carro. É o carro que arrasou o Despotismo. A figura deste jaz entre ruínas com um punhal que amargamente dirige contra si mesmo.

O triunfo do Gênio é de outro tipo: suas valentes conquistas foram feitas tendo por base o erro. A esse preço deve seu acesso ao Templo da Pátria. Tal é o sentido do grupo que completa a parte esquerda do frontão. Ali aparece o Gênio da Filosofia, armado com a tocha da

${ }^{4}$ QUATREMÈRE, A., Rapport fait au Directoire du Département de Paris, sur les travaux entrepris, continues ou achevés au Panthéon Français, 22-X-1793. 
Verdade (a mesma alegoria aparece no sepulcro de Rousseau), combatendo o erro e os preconceitos.

Estes foram representados pelo artista sob a forma de Grifo, animal quimérico que na linguagem da Alegoria transformou-se no símbolo do erro. Um deles retrocede ante o fulgor de uma luz que destrói os prestígios; o outro expira sob os pés do Gênio. $\mathrm{O}$ carro a que estavam atrelados mostra, abatidos e perdidos, os emblemas das diversas superstições: a Trombeta, as Tábuas hieroglíficas, os instrumentos do Mistério, o Tripé sagrado, todos os signos que por muito tempo abusaram da imaginação, enganando os sentidos, prestando, em sua ruína, uma homenagem ao Gênio da Razão e ocupando a parte mais baixa do frontão.

Referindo-se a outros detalhes esculpidos em código alegórico, Quatremere prossegue:

O do meio, que é de Boichot, tem por tema a Declaração dos Direitos. É a Natureza, sob a forma de uma mulher metade despida e metade vestida, significando assim que o homem jamais a conhecerá inteira, ocupa a parte central da composição. Tem uma cornucópia, simbolizando a produção. O abutre, símbolo da destruição, jaz a seus pés. Sua outra mão repousa sobre a Tábua dos Direitos do Homem, que oferece à admiração da França. A Natureza traz, a seguir, suas duas companheiras, a Igualdade e a Liberdade. A Fama aparece no céu: anuncia a todos os povos o despertar da França e o reino da Liberdade.

O primeiro baixo-relevo do lado direito (sob a ótica do Templo, não do espectador) é o de Le Sueur. Este artista encarnou a Instrução Pública. A Pátria a apresenta aos Pais e Mães de família. Rapazes e moças saem ao seu encontro e as crianças a abraçam como se fosse sua Mãe. O Artista quis que se entendesse a importância da instrução na idade mais tenra.

O segundo, do mesmo lado, representa a nova Jurisprudência. A Pátria, sentada à entrada do Templo das Leis, mostra à Inocência a estátua da Justiça e a salutar instituição do júri. A Inocência abraça com arrebatamento essa estátua tutelar. A Jurisprudência civil e penal é representada de pé, desfrutando o prazer de defender os inocentes. Essa obra é de Roland.

Assim como toda sociedade digna deve implantar a Instrução e a Justiça para todos, todos por sua vez, devem, à Sociedade, a obediência de suas Leis e o sacrifício de suas pessoas à coisa pública. Tais são os motivos dos baixo-relevos do lado esquerdo.

O primeiro, representando a Entrega patriótica, é de Chaudet. Nele se vê um guerreiro moribundo em defesa da República. O Gênio da Glória e o da Força o sustentam enquanto expira. Sua desfalecida mão deposita no altar da Pátria o ferro que usou para defendê-la, e seus últimos olhares dirigem-se também à Pátria, que se aproxima dele apresentando-lhe a coroa do Martírio cívico.

O segundo do mesmo lado é o Império das Leis. A Pátria, com o Cetro na mão, ensina ao povo as leis como expressão da vontade geral. Um Ancião se prostra jurando obediência. Um jovem guerreiro avança jurando defendê-la. Esse baixo-relevo é de Fortin.

Este Monumento consagrado aos Grandes Homens, antes de tudo, é consagrado às Virtudes e aos Talentos que os fazem. Convinha pois expressar sensivelmente todos os títulos de mérito e de honra que compõem sua reputação. Era de se esperar que fossem encontrados neste Elíseo todos os signos correspondentes aos objetos de estima e valor humanos, que sempre fizeram os encantos e a glória da vida.

Foi de acordo com essa ideia tão natural que se estabeleceu a divisão das alegorias das quatro naves: a Filosofia, o Patriotismo, as Ciências e as Artes.

Representando esses emblemas, os Artistas tiveram a intenção de relacioná-los estreitamente ao caráter do edifício e à Revolução por meio de alusões tão simples como plausíveis. A breve descrição que se segue o provará.

A nave de entrada mostrava na pequena cúpula ovalada que coroa a tribuna, quatro pequenos nichos, antes ocupados por pequenos grupos de anjos. Agora substituídos por quatro temas ou ornamentos que, utilizando como emblema quatro animais alados, representam a apoteose da Filosofia, da Virtude, da Ciência e do Gênio.

$\mathrm{O}$ primeiro nicho, à direita dos espectadores, logo depois da entrada, tem por tema a História. Seu autor, Stouf, representou-a sob a forma de uma mulher tranquila em meio a fulminantes relâmpagos, escrevendo, sobre as asas do Tempo, as catástrofes e as Revoluções dos Impérios. É o que se lê numa Tábua que o Tempo lhe apresenta, e ainda melhor nas ruínas dos cetros e coroas, que a Musa da História pisa implacavelmente. 
A Ciência Política constitui o tema do primeiro baixo-relevo da esquerda. Compõe-se de duas figuras, a Força e a Sabedoria, que juntas mantêm o Timão e a Fácia da República. Essa obra é de Auger.

O terceiro do mesmo lado representa a Legislação e se deve a Du Pasquier. A Ciência das leis, inspirada pela efígie de Licurgo, escreve seu código e o apresenta à República, cujo emblema é uma Colmeia.

O quarto à direita é a Moral, representada por uma mulher que instrui um jovem e lhe ensina a sentença básica de toda ordem: "Não faças aos outros o que não queres que te façam". Esse baixo-relevo é de Beauvallet.

A nave setentrional, ou do cruzeiro, à esquerda de quem entra, é dedicada às Ciências. Suas abóbadas ostentam os atributos da Física, da Geometria, da Astronomia e da Agricultura.

A Física, obra de Baccarit, nos é apresentada na figura de uma mulher, que é a Ciência, levantando o véu que escondia a Natureza.

O baixo-relevo correspondente representa a Agricultura com seus instrumentos de aradura e os produtos que são a verdadeira riqueza do Estado. A Pátria lhe oferece a coroa recompensadora dos trabalhos úteis. $\mathrm{O}$ autor desse baixo-relevo é Lucas.

Suzanne personificou a Geometria por meio da figura de duas mulheres. Uma delas, a Teoria, é reconhecível por sua lâmpada, símbolo do estudo. É ela que dirige e regula as operações de outra figura, que é a Geometria prática, ocupada em traçar sobre o globo as novas divisões da França em departamentos.

A Astronomia é o quarto tema. Bastante tempo antes do novo calendário ser decretado, Delaistre tratou o tema no Panteão, também em baixo-relevo. Esse artista representou a Astronomia mostrando à Cronologia, no Zodíaco, o signo do equinócio de outono como indicador de época para o novo ano. A Cronologia escreve num Cipo essa nova era da República Francesa.

Às ciências sucedem as artes e os ofícios. Finalmente, as virtudes patrióticas: a Força, a Vitória, a Sabedoria, a Prudência, a Boa Fé, o Desinteresse, a Entrega e o Amor à Pátria culminam a série de alegorias. Alegorias que se repetem e realçam diferentes partes do Panteão, especialmente as relativas à Pátria e ao heroísmo que lhe é oferecido. $\mathrm{O}$
Panteão projetado por Quatremere de Quincy reflete, como dizíamos no começo de seus textos, a clara intenção pedagógica dos líderes ideológicos da Revolução, intenção centrada sobretudo na nova noção de pátria e cidadania, posta à prova pelos rigores da incessante guerra que a França tem de enfrentar, dentro e fora de suas fronteiras.

Penetremos no ambiente das primeiras panteonizações, antes mesmo de serem realizadas no próprio Panteão. Naqueles primeiros dias, quando a beleza das moças era comparada à liberdade e sua simplicidade à igualdade, o entusiasmo revolucionário não queria - apesar de alguns intransigentes discriminar os filósofos do século XVIII que agora brilhavam como áugures de uma pátria melhor. Assim, faz sentido essa celebração de Rousseau, Franklin, Voltaire e Mirabeau feita pelos jacobinos em 12 de fevereiro de $1792^{5}$ :

Cidadãos, cidadãs, que hoje reunis neste recinto as imagens tão reverenciadas desses filósofos, primeiros deuses da liberdade que criaram de um pólo a outro do mundo, vós que prestais a sua memória o culto e as homenagens que todo cidadão amigo da igualdade e da humanidade lhes deve, segui vosso caminho, marchai com firmeza e sob a proteção das leis e dos estandartes da liberdade; ensinai, cultivai a moral pura dos Voltaire, dos Rousseau, e assim como Franklin e Mirabeau amai com grande estima a vossa pátria, defendendo-a de todas as investidas dos déspotas: arrancai seus cetros e colocai-os nas mãos da razão, a única que deve governar o universo...

Ilustres criadores da liberdade, recebei agora o tributo dos elogios que com toda justiça o universo vos deve. Que essas coroas elaboradas pela virtude, concedidas pela razão e pela posteridade, possam vos ressarcir da impotência da inveja; e se é verdade que a alma ainda tem sensibilidade entre os mortos, gozai de vossas obras. Falastes, e isto foi suficiente para que desaparecesse o despotismo, para que agonizasse o fanatismo, para que se preparasse a queda dos tiranos e a igualdade reinasse sozinha no trono do mundo.

${ }^{5}$ Société Fraternelle des patriotes des deux sexes, Défenseurs de la Constitution, Extrait $d u$ Procès-Verbal de la séance du Dimanche, 12 Février 1792, pp. 9, 11, 12... 
Franklin!, nascido numa condição que se tem chamado de obscura, demonstrou, fazendo a revolução em seu país, que as virtudes e os talentos não distinguem classes de homens.

Tu, imortal Rousseau!, que em teu Contrato Social, lançaste as bases dessa sublime Declaração dos Direitos do Homem, admiração de filósofos e desalento de déspotas.

E tu, grande Voltaire!, gênio profundo e vasto que levaste a tocha da filosofia aos antros tenebrosos dos preconceitos e do fanatismo e qual novo Hércules, abateste com a clava da ciência as cabeças sempre ressurgentes dos devotos e dos velhacos encapuzados.

Recebei a coroa cívica. Senti vossa imortalidade ao som das aclamações e dos sufrágios de um povo livre. Que o exemplo de vossa reputação faça surgir êmulos de vossos talentos! Talvez nossas esposas, mães e cidadãs tenham em seu seio um Franklin, um Rousseau, um Voltaire! Que a razão ultrapasse sua idade, que o patriotismo desenvolva seus talentos; a tribuna, sua eloquência e o amor à Pátria, esse germe fecundo de todas as virtudes: a humanidade, a beneficência, a coragem, a tolerância e tudo que compõe o precioso tesouro de um herói do patriotismo!

Santa Genoveva cederia passagem aos novos patronos de Paris e da França. A panteonização oferecia novos santos ao povo, que ao invés de milagres haviam dado liberdade. Assim, M.-J. Chénier pedia a panteonização de Descartes ${ }^{6}$ :

Hoje em dia, Paris e a França inteira não têm outra padroeira além da Liberdade. Um templo foi elevado a Genoveva: esse templo, agora tão envelhecido como os preconceitos, afunda sob o peso do tempo; mas entre esses escombros religiosos, perto dessas relíquias sagradas às quais, em face das calamidades do povo, a piedosa credulidade de nossos antepassados implorava com uma confiança estéril, em meio a esses altares enriquecidos pelo temor, a essas tumbas adornadas pelo orgulho, uma pedra estreita e sem arte alguma cobre os restos de René Descartes ...

Mas a apoteose e a panteonização de mais repercussão foram as dedicadas a Voltaire. Se, por um lado, esta celebração se impunha como

${ }^{6}$ CHÉNIER, M.-J., Rapport ... in Procès-Verbaux du Comité d'Instruction Publique de la Convention Nationale, Paris, 1894, t II, p. 576. reconhecimento óbvio da consciência revolucionária, pelo menos frente ao antigo regime, será que por outro lado Voltaire merecia a panteonização?

... esse adulador dos grandes, que desprezava o povo, esse homem de espírito volúvel, sem lei, sem princípios, se ainda vivesse estaria à altura da Revolução? Mostraria essa majestosa integridade, essa atitude que é a beleza da alma verdadeiramente livre?

Por outro lado, a festa parecia uma provocação ao fervor do catolicismo popular e uma ofensa ao clero juramentado na Constituição. Assim pensava, reivindicando a suspensão da homenagem a Voltaire ou ao menos uma celebração muito mais discreta, um numeroso grupo de jansenistas e de galicanos. ${ }^{8}$

À oposição que se ergueu contra a apoteose de Voltaire, Gudin de la Brenellerie ${ }^{9}$ respondeu com estes esclarecimentos:

Sempre há quem não seja nem de seu século nem de seu país, dizia Voltaire. Tais são os que hoje querem se opor ao decreto que concede a este primeiro vencedor dos preconceitos, a este Hércules francês, as homenagens que a pátria agradecida presta aos grandes homens.

Voltaire... pai da liberdade de pensamento, também é o pai da liberdade política que sem ela não teria existido... Os hipócritas se utilizam sempre do nome de Deus para prejudicar os homens: fingem ignorar, agora, que nenhum teólogo combateu com tanta força o ateísmo como Voltaire; mostram que confundem uma festa cívica com as festas eclesiásticas; as cerimônias triunfais com as cerimônias fúnebres. Em suas perspectivas estreitas não concebem que essas homenagens possam ser prestadas a outros grandes homens que não sejam católicos..

Esse triunfo dos grandes homens não é, de fato, nem um cortejo fúnebre que não se pode recusar a ninguém, nem uma festa religiosa, sagrada aos olhos de uma seita e profana para todas as demais. É uma pompa cívica; é uma homenagem solene espontaneamente oferecida por cidadãos livres, por corações generosos, inflamados pelo amor à glória, sensíveis às grandes coisas e que querem inspirar à juventude

\footnotetext{
${ }^{7}$ ROBINET, op. cit., p. 541

${ }^{8}$ Idem, p. 542.

${ }^{9}$ GUDIN DE LA BRENELLERIE, P. Ph., Réponse d'un ami des grands hommes, aux envieux de la gloire de Voltaire, s.f., começo e pp. 2, 5, 9 e 10.
} 
o desejo de merecer essas homenagens; é a melhor educação que se possa dar aos jovens; é a que recebiam na Grécia...

Thibaudeau ${ }^{10}$ recordava-o mais friamente em suas memórias, escritas na Alemanha:

Essas farsas não passavam de frias imitações dos gregos e dos romanos. Era em vão que de modo imprevisto se queria levar uma nação envelhecida na civilização aos costumes simples das antigas repúblicas.

Rabaut Saint-Etienne comentou assim a apoteose de Voltaire - o mesmo Rabaut que David situa no primeiro plano do Juramento do Jeu de Paume - como protestante defensor da liberdade religiosa ${ }^{11}$ :

Mas um homem, mais do que todos os outros, fazia avançar a razão na França; o mesmo que, ainda jovem, seduziu todos os espíritos com os encantos de uma poesia brilhante que reunia todos os talentos, aperfeiçoava todos os gêneros, combatia todos os abusos, tomava a defesa de todos os oprimidos e que, durante sessenta anos, dirigiu ou influenciou a opinião pública. Pergunto a toda a atual geração, a todos os que pelo menos aprenderam a pensar por si próprios e a elevar-se acima dos preconceitos, se não têm uma dívida para com Voltaire. Sua incansável perseverança fazia a própria preguiça levantar-se, e jamais permitiu que seu século adormecesse na busca da verdade. Suas judiciosas lições, suas apuradas críticas e suas picantes sátiras foram o açoite constante dos preconceitos até que chegou o tempo em que, depois de ter derrubado mil atletas da estupidez, dominou sozinho na arena.

Incansável protetor dos desgraçados, amava a liberdade porque amava a humanidade com paixão. Todos os princípios da liberdade e todas as sementes da revolução estão contidos nos escritos de Voltaire. Foi ele quem a predisse e a iniciou, minando sem cessar o terreno onde o despotismo não interrompia suas obras; feliz por ter a natureza lhe ofertado o tempo suficiente para iluminar duas gerações. Com a liberdade de pensamento fazendo tantos progressos cotidianos, assim como os poderes do arbítrio também cometiam

${ }^{10}$ THIBAUDEAU, A.C., Mémoires sur la Convention, et le Directoire, Paris, 1824, p. 56. ${ }^{11}$ RABAUT, J. P., Almanach historique de la Révolution Française pour l'année 1792, Paris, 1791, p. 19. faltas diariamente, os franceses alcançaram logo o momento que a mudança de espírito clamava maciçamente.

Foi então que se formou uma escola de homens superiores, cujos escritos difundiram uma infinidade de verdades úteis; e esses, formando por sua vez uma multidão de discípulos, estabeleceram-se como um tribunal esclarecido para julgar reis e ministros, o tribunal da opinião pública.

Ninguém podia julgar tão bem, como Rabaut Saint-Etienne, o efeito popular das ideias voltairianas, sobretudo no que tange à tolerância. A defesa de Calas, como a do barão de la Barre, situaram Voltaire como paladino de uma causa que já conquistara a consciência da maior parte da opinião pública. O protestantismo, a que Rabaut concedeu com seus esforços o edito de Tolerância de 1787, tinha especial carinho por Voltaire, que o defendera já muito antes do caso Calas.

Charles Villette propôs, na primavera de 1790, um serviço solene em homenagem a Voltaire ${ }^{12}$ e o traslado de seus restos ante a perspectiva de venda do mosteiro de Sellieres. Sugeriu um monumento na basílica de Sainte-Genevieve, em frente à tumba projetada para seu arquiteto, Soufílot. A apoteose e panteonização de Voltaire teria lugar em 12 de julho de $1791^{13}$ :

"Nas revoluções políticas, onde os espíritos se exaltam para defender tanto o erro como a verdade, onde os ódios partidários (mais fortes do que os ódios particulares) sucedem aos afetos doces da sociabilidade, dá gosto poder repousar a vista num espetáculo que reúne todos os sufrágios, que aproximou por um instante os espíritos mais opostos, e que a história conservará cuidadosamente como triunfo completo das luzes e da filosofia. A assembleia constituinte decretaria, em 30 de maio, aniversário da morte de Voltaire, que lhe fossem concedidas as honras devidas aos grandes homens. Sem dúvida não havia necessidade de decreto algum para que Voltaire fosse colocado entre os benfeitores das nações: que lei podia obter maior admiração e reconhecimento da Europa inteira, quase se deve dizer do universo? Mas importava ao órgão legislativo expiar com

\footnotetext{
${ }^{12}$ VILLETTE, Charles, Lettres Choisies, Paris, 1792.

${ }^{13}$ Collection complète des Tableaux historiques de la Révolution Française, Paris, 1804, Quadro ${ }^{\circ} 55$, p. 221
} 
toda solenidade o ultraje feito à razão universal na pessoa de um grande homem. Paris ansiava pela entrada gloriosa desses restos mortais - que um arcebispo imbecil e um sacerdote fanático haviam privado de sepultura, que não haviam podido se furtar da raiva de seus inimigos, e tiveram que ser levados furtiva e dissimuladamente de Paris há três anos atrás, para repousar em silêncio na solidão monástica de Sellières, sendo ali visitados apenas por alguns sábios, que não hesitavam em afrontar a superstição reinante, e por alguns estrangeiros, surpresos de que um deserto acolhesse aquele cujo nome percorria o mundo. Os amigos das letras e da liberdade pressionavam com todo empenho a favor desse triunfo que devia humilhar tanto o despotismo como a ignorância; dedicavam coroas cívicas ao homem que suscitara na opinião pública a revolução que então ocorria no governo. Sua apoteose foi marcada para 12 de julho.

A antiguidade mais de uma vez atestara como o reconhecimento público colocava no rol dos deuses o guerreiro salvador de sua pátria; e, numa religião dia-a-dia enriquecida com os tesouros da imaginação, a ardente inventiva dos gregos se comprazia em dotar de filiação divina o mortal que assombrara a terra. A adulação romana depois transferiu a seus imperadores essa honra, que só era devida aos benfeitores das nações; e se Tito e Marco Aurélio entraram no Olimpo, sua associação a Tibério, Calígula, Nero, etc., provou sobejamente que esse Olimpo não era morada exclusiva da virtude. Esses dois povos, em suas melhores decisões, só haviam prestado homenagem a guerreiros e príncipes: estava reservado à nação francesa regenerada o poder de conceder as supremas honrarias ao poeta-filósofo que não havia exercido outro poder senão o do gênio, e cujas façanhas, atestadas pela queda dos preconceitos, haviam sido um benefício para o universo.

Um funcionário municipal viajou de Paris a Sellieres para levar o decreto do órgão legislativo. Já era tempo de recebê-lo. Uma vez posta à venda, a abadia de Sellieres precisava colocar devidamente o depósito precioso que albergava; todos os distritos circunvizinhos haviam combinado dividir entre si os restos de Voltaire, assim como sete cidades da Grécia haviam disputado a honra de ser o berço de Homero. $\mathrm{O}$ decreto pôs fim às pretensões mas não ao sentimento desses amigos da liberdade.

A cerimônia de traslado apresentou tudo que de mais emocionante e majestoso pode derivar da solenidade da antiguidade e da reunião de todas as classes de um povo livre. À frente do cortejo podia-se ver os prefeitos das aldeias com seus trajes municipais: seguiam-nos longas filas dos guardas nacionais dos arredores, com seus fuzis adornados por ramos de carvalho e louro. Uma música suave e campestre tangia árias enternecedoras que expressavam a dor de uma separação necessária: mas os que até então o haviam possuído se consolavam da perda com a ideia da glória que o esperava no Panteão.

A cada momento e de toda parte chegavam novos grupos de cidadãos que ofereciam coroas e atiravam flores. À volta, espetáculos emotivos e de vivos sentimentos: as mães levantavam os filhos nos braços para imprimir-lhes a lembrança desse glorioso acontecimento: as mulheres tocavam o sarcófago com panos seus e depois os beijavam e guardavam com respeito; os anciãos, com seus tardios passos, seguindo o cortejo com o olhar, erguiam as mãos ao céu, bendizendo-o por poder viver esse espetáculo tão belo; numa palavra, todas as idades e todas as classes da sociedade mesclavam suas homenagens, porque todos reconheciam as boas obras desse grande homem. As estradas estavam arrumadas com arcos de triunfo. Os lenhadores e camponeses os adornavam com flores, folhagem, e com guirlandas tão simples como os seus corações; ao entardecer, tochas e outras iluminações assinalavam o caminho a tomar; à noite, verdadeiras cúpulas de folhas cobriam sua cabeça: temia-se não testemunhar-lhe o respeito suficiente, a veneração que inspirava.

o carro cerimonial que o transportava era metade camponês, metade triunfal: com vinte pés de altura, estava montado em quatro rodas e era puxado por quatro cavalos. Nos ângulos do carro erguiam-se quatro pilastras de mármore branco, ornamentadas com graça e enlaçadas com guirlandas de flores. Esses suportes eram coroados por um baldaquino, no alto do qual ondulavam as cores nacionais Cada coluna sustentava o sarcófago com anéis e fitas, o qual repousava docemente sobre um fundo de rosas entrelaçadas. Ao seu redor havia sido instalada uma galeria protegida por choupos, ciprestes, faias e olmos: dir-se-la um bosque em movimento, ou antes o bosque sagrado de Helicon animado pela presença do deus dos versos.

Assim, em meio aos aplausos universais, às danças e à música, ele la se aproximando de Paris, poucos dias depois de Luís Capeto ter voltado. Essas duas épocas, tão próximas e tão diferentes, estabeleceram afinal, vitoriosamente, o triunfo do gênio sobre a 
realeza. Um príncipe pérfido não podia colher outra coisa além do desprezo daqueles que ousava chamar de súditos, ao passo que um simples cidadão recebia, inclusive depois de sua morte, a homenagem universal de um povo justo e agradecido".

O jornal La Bouche de $\mathrm{Fer}^{14}$ comentava assim a passagem do carro de Voltaire diante dos protagonistas do Antigo Regime:

Do canto de um sótão do pavilhão de Flora, através de sua gelosia, o poder executivo vira passar o carro triunfante de Voltaire. Viu esse mesmo povo, que há não muito tempo manifestara, nos mesmos lugares, seu desprezo a um rei covarde, divinizar o grande homem cujo gênio, dedicado sem descanso a despertar as nações de sua letargia, não pode morrer jamais. República das Letras, república universal, santa religião dos homens livres, depois de tantos séculos de combates, que estas primícias de vossa glória, recolhidas sobre os escombros de um trono que lançara raízes há novecentos anos atrás, animem ainda mais o vosso incansável zelo!

Continua a descrição dos Tableaux:

O sarcófago passou a noite no local montado na ruína da Bastilha. Desejava-se que os manes de Voltaire fossem testemunhas da ruína dessa fortaleza onde o despotismo o havia trancado. Que diferença entre aqueles tempos e este de seu triunfo! O palácio da vingança já não era mais do que um monte de escombros, dos quais surgiam pouco a pouco tufos de mirtas, de roseiras e de louros que apenas a presença de uma divindade parecia capaz de fazer crescer naquele lugar de terror. Uma música fascinante substituíra o ruído dos grilhões e ferrolhos; aos gemidos dos calabouços haviam sucedido os aplausos de um povo imenso; às trevas da noite, um horizonte brilhante; ao Tártaro, o Elíseo; e estes milagres eram obra de Voltaire. Lia-se numa pedra da Bastilha: 'Neste mesmo lugar onde o despotismo o acorrentou, Voltaire recebe as homenagens de um povo em liberdade'.

A partida fora marcada para as oito horas; e antes das seis uma grande multidão enchia os locais. Sua área, de uma légua de semicírculo, não bastava para a cerimônia. $O$ cortejo avançava na ordem mais imponente. A cavalaria abria a marcha; a seguir vinham

${ }^{14}$ La Bouche de fer, $\mathrm{n}^{\circ}$ 90, 12- VII-1791. o batalhão de jovens alunos da pátria, a guarda nacional, os clubes, as sociedades fraternas, os carregadores do mercado, os vencedores da Bastilha e aqueles que, reunindo todas as suas forças, trabalharam na demolição de suas torres. Em meio a eles via-se uma bandeira esfarrapada, a mesma que fora arrancada das mãos do pérfido Launay durante a tomada da horrível fortaleza. Seguiam-lhes as viúvas cujos esposos morreram pela conquista da liberdade. Os inválidos vinham depois junto com nossos irmãos de armas dos departamentos. Sobre padiolas cheias de almofadas de veludo, destacavam-se o busto de Rousseau, a planta da Bastilha em relevo e couraças e escudos enferrujados achados entre os escombros. Os alunos das artes, vestidos como na antiguidade, usavam guirlandas de carvalho em forma de insígnias. Várias inscrições em homenagem a Voltaire mencionavam suas obras-primas e as vitórias de seu gênio. Outros portavam os atributos das musas: a máscara de Talía, o punhal de Melpomeno, a lira de Polimnia, a pluma de Clio, a trombeta de Calíope. Parecia que desfilavam os deuses da antiguidade. A coleção magnífica das obras de Voltaire, dentro de uma arca de ouro, comovia todos os espíritos, assombrados de que o espírito de um único homem tivesse produzido o que faria a riqueza de todo um século. Homens vestidos com túnicas levavam a sua estátua, todos teriam querido vê-la viva para que pudesse presenciar sua glória. Atrás desfilavam os atores com as vestimentas dos teatros, os homens de letras, os juízes de paz, os distritos, os tribunais, o departamento, a prefeitura, a assembleia nacional, os ministros e os embaixadores de todos os povos da Europa.

Um grupo de músicos, com instrumentos de forma antiga e executando hinos novos, precedia o carro magnífico que substituía o que o trouxera de Sellieres. Esta obra-prima de criação recente era transportada sobre quatro rodas de bronze. Todas as artes haviam conjugado seus esforços para compor esse carro triunfal; o gosto mais apurado presidira a toda sua ornamentação. Sobre uma ampla plataforma rodeada de folhas de carvalho, erguia-se um sarcófago de granito oriental. Sobre as faces laterais, gênios imersos na dor deixavam cair suas tochas. Podia-se ler inscrições nos quatro lados do sarcófago. Acima dos degraus, cobertos de veludos azuis salpicados de estrelas de ouro, elevavam-se quatro candelabros antigos, nos quais o perfume e os incensos ardiam abundantemente. Um leito de repouso, colocado sobre o sarcófago, portava uma estátua de grande semelhança com Voltaire, meio deitada, em atitude 
de sono. Estava vestida de púrpura; e a Imortalidade, figurada por uma moça que descia do céu, colocava-lhe na cabeça uma coroa de estrelas douradas. Ao timão, que saía da garganta de um dragão, haviam sido presos doze cavalos brancos, conduzidos pela mão de guias vestidos à romana.

Esse magnífico cortejo, composto de cem mil homens, desfilando na presença de seiscentos mil espectadores, parou primeiro diante da ópera, soberbamente decorada. Sobre um altar antigo achava-se o busto do homem imortal, três medalhões portavam as inscrições do Templo da Glória, de Pandora e de Sansão. Voltaire chega finalmente ao esplendoroso cais que desde então tem seu nome, deixando para trás o pavilhão de Flora de onde o ignominioso Luís Capeto contempla esse triunfo por trás de uma gelosia. A segunda estação foi feita diante da casa de Charles Villette, onde Voltaire morreu, onde ainda mora seu coração. Cinquenta jovens cidadãs, vestidas de branco com faixa azul e a cabeça coroada de rosas, recebem o grande homem e o acompanham até o derradeiro asilo. Entre elas destacam-se a viúva e as filhas do infortunado Calas, cobertas de luto. Sua filha adotiva, a cidadã Villette, avança para abraçar a estátua: coroa-a, apresenta-a a seu filho como a uma divindade tutelar. $\mathrm{O}$ excesso de emoção que sentia sufocou-a de tal maneira que teve de retirar-se para sua casa; porém, uma vez tendo recuperado todos os sentidos, voltou, resoluta, para acompanhar o cortejo. $^{16}$

A marcha continuava ao som de uma música celestial. Sobre a fachada da antiga Comédie Française lia-se: "escreveu Édipo aos dezessete anos". Mais adiante, o templo de Melpomeno, ricamente enfeitado, esperava a divindade cujos oráculos repetiram tantas vezes. Numerosos cartazes pendiam de todas as colunas. No frontão lia-se: "escreveu Irene aos oitenta e três anos". Todos os atores, com seus costumes de Brutus, Oromano, Nanine, aproximaram-se de seu pai para oferecer-lhe flores e incenso. A música e os cânticos

${ }^{15}$ Em carta de 13 de abril de 1791 (Lettres, op. cit.), Charles Villette dizia a seus amigos: "Tomei a liberdade de apagar, na esquina de minha casa, a inscrição: Cais dos Teatinos; e a substituí por: Cais Voltaire". Essa iniciativa logo foi saudada pelos frequentadores do café Procope-Zoppy.

${ }^{16}$ La Bouche de fer (n ${ }^{\circ}$ 90, 12-VII-1791) fez o seguinte comentário sobre a passagem de Voltaire pela casa de Villette: "A amizade é engenhosa, e a casa de Charles Villette oferecia um espetáculo delicioso. Infeliz daquele que o tiver contemplado com sangue-frio". mesclavam-se aos aplausos dos espectadores. Foi com esse comparecimento unânime, com os votos e as homenagens de todo um povo, que Voltaire fez a sua entrada no Panteão francês.

A narração da apoteose de Voltaire que Charles Villette faz em uma de suas cartas é a mesma que sai nos Tableaux, com acréscimo de vários parágrafos significativos. ${ }^{17}$ Ele começa elogiando com grande entusiasmo a ideia da apoteose de Voltaire: "A apoteose de Voltaire é o homem à imagem de Deus". ${ }^{18}$ Antes, em outra carta, ${ }^{19}$ dissera: "Se Jean-Jacques fez em prosa uma Constituição, Voltaire fez a Revolução em verso", indubitável alusão às tragédias republicanas e libertárias de Voltaire. A missão do gênio era considerada importantíssima: "Seus volumosos escritos foram às vezes a nuvem misteriosa e às vezes a coluna de fogo que nos guiaram por entre os inúmeros preconceitos que entravavam a marcha do Espírito humano". "A cerimônia de seu traslado foi feita com uma pompa tão majestosa como estimulante". ${ }^{20}$

Ao texto publicado nos Tableaux acrescenta que os anciãos que não podiam acompanhar o cortejo "erguiam as mãos ao céu e imaginavam algo tão divino que os fazia chorar". O carro é qualificado de "metade pastoral, metade triunfal". E destaca com complacência: "Havia inclusive padres mesclados à procissão cívica: eram os capelães de Apolo que vinham cantar hinos ao Deus do Gosto, enquanto se dirigia ao seu templo".

$\mathrm{O}$ relato de Villette em sua correspondência acrescenta detalhes de emoção ao dos Tableaux: "parecíamos estar recebendo um Deus"; "dir-sela que esse triunfo atraía os olhares dos Imortais;". "Assim, em seu entusiasmo religioso, David dançava ante a arca sagrada; e assim as Graças formavam uma marcha cadenciada ante o carro de Apolo";22 "As árvores tinham mais homens que galhos"...

${ }^{17}$ Cf. AULARD, La Société des Jacobins, Paris, 1889, t. I, p. 367, para o discurso de Charles Villette no Clube dos Jacobinos pedindo o traslado de Voltaire a Ste. Geneviève.

${ }^{18}$ VILLETTE, Ch., op. cit., p. 174

${ }^{19}$ Idem, 15-V-1791.

${ }^{20}$ Idem, pp. 174 e 177

${ }^{21}$ Idem, p. 185.

${ }^{22}$ Idem, p. 180. O antigo cabeleireiro de Voltaire somou-se ao séquito que iria buscar os restos do filósofo em Sellieres. Em sua carta a Villette (p. 97), compara a arca de Santa Genoveva, "dócil padroeira de Paris", à "patriótica e filosófica" tumba de Voltaire. 
A passagem do cortejo na frente de sua casa é o auge da descrição repleta de religiosidade que Villette nos oferece. O sentimentalismo mais declarado, proibido pela filosofia moral de boa parte dos ilustrados, junto com a exaltação de uma revolução protagonizada pela coragem e pelo espírito do homem sustentam o relato ${ }^{23}$ :

Voltaire chega afinal ao estupendo cais que atualmente tem o seu nome. Voltaire morreu em minha casa; seu coração repousa ao lado de sua imagem. Lembrava-me de nossos encontros de Ferney, daquele tempo em que a amizade o fazia dizer: tecum veniam!; e eu lhe respondia: veni! coronaberis. Procurei arrumar minha casa o mais que pude. Previa que receberia muita gente e, com esta finalidade, coloquei na rua um estrado espaçoso. A visão de cinquenta jovens, dispostas como num anfiteatro, belas como as Graças e vestidas como Efigênia, todas de túnica branca, faixa azul e uma coroa de rosas na cabeça acabou também não sendo um dos ornamentos menores da festa. Em meio a esse encontro, por si mesmo brilhante, surgiam as duas filhas de Calas cobertas de luto. Era uma recordação profunda, a do mártir que o fanatismo havia degolado. Voltaire lhe devolvera a honra, não podendo devolver-lhe a vida: e suas filhas, com os olhos umedecidos pelas lágrimas, aproximavam-se para estreitar seu sepulcro e dar graças aos seus manes.

Voltaire aparece: a terra se cobre de flores; chovem coroas a seus pés. A senhora Villette se adianta para abraçar sua estátua; esquece que está falando com um bronze inanimado. Voltaire é coroado mais uma vez pela piedade filial. Levanta nos braços o seu filho e o dedica à Divindade que plenifica sua alma. Porém, inundada de sentimento, sua cabeça se inclina sobre o peito de seu pai adotivo; aperta-se contra seu coração e fica como que aturdida; foi preciso retirá-la. Esta cena se desenrolava sob os acordes de uma música dilacerante. Suas fúnebres notas nos recordavam que aquele homem já não existia. Mas o sentimento de sua imortalidade despertava incessantemente...

Villette desenvolve o mesmo raciocínio já exposto nos Tableaux, mas sem comparar a apoteose de Voltaire à humilhação de Luís XVI ${ }^{24}$ :

${ }^{23}$ VILLETTE, Ch., op. cit., pp.195-196.

${ }^{24}$ Villette se considerava democrata, mas respeitava o rei, e especialmente a rainha, a quem tinha como excelente protetora das artes na França (Idem, op. cit., 20-X-1791).
Que um simples particular que não tem senão sua pena para apresentar ao mundo erga-se a essa altura, a essa soberana hegemonia, apenas com as armas do pensamento; que faça calar as paixões com sua presença e faça falar a Famosa razão; que tenha tantos partidários como leitores, e tenha inclusive seu sepulcro carregado triunfalmente pelo reconhecimento e pelo entusiasmo nacionais, é um fenômeno único nos faustos da história, e não menos extraordinário do que o objeto que o suscita. Ó, Voltaire! Goza para sempre da veneração dos homens e dos séculos! $!^{25}$

David, Chénier e Gossec foram os principais artífices dessa apoteose. O neoclassicismo histórico e naturalista, o melodismo e a prosa enfática sobre a imortalidade e a sacralidade do gênio proliferaram com espontaneidade e profusão. Entretanto, a teatralidade, a afetação e a lembrança ambígua de Voltaire, crítico e adulador, facilitaram a sátira do acontecimento.

Às vezes aproveitando fragmentos das próprias obras de Voltaire, uma sátira de tom claramente realista ${ }^{26}$ ironiza a respeitabilidade do povo ("Reconheço o povo, mutável num dia,/ Prodigaliza, fácil, seu amor e sua tirania"); sua prepotência orgulhosa depois do ataque à Bastilha ("Coragem, amigos, somos centenas contra um!'”); a ambição dissimulada dos primeiros líderes da revolução ("Dirijo sem talento o bobo advertido;/ Meu império desmorona se sou reconhecido"); a ambiguidade de Voltaire no intuito de obter o aplauso e a fama ("Para mim, mesquinho, uma estátua,/ de orgulho me embriagarei"; "Não vou decidir entre Genebra e Roma"; "O infortúnio e o tormento onde nos encontramos,/ A festa e o elogio onde não estamos"); a afetação virtuosa dos filósofos ("Os mortais são iguais, não o é sua ascendência./ São a bolsa e a coragem que fazem a diferença": versos cantados por. um coro de virgens burguesas, com a filha de um banqueiro à testa); sobre a corrupção nos cargos ("À frente da Academia Francesa marcha o senhor Sédaine que, como todo mundo sabe, apresentou sua graduação na maçonaria para obter as honras da cadeira, e produziu suas peças teatrais para ser recebido na academia de arquitetura..."); sobre a frivolidade dos homens de ciência ("O senhor marquês de Condorcet, presidente do Clube de 89, tem na mão a carta de Achmet Eliazed, na qual

${ }^{25}$ VILLETTE, op. cit., p. 119.

${ }^{26}$ L'Apothéose de Voltaire ou le triomphe de la Religion et des Moeurs, s.l.n.f. 
esse muçulmano narra a lição de física oriental que dava à marquesa de Ferrieres enquanto seu marido se entretinha com o telescópio"), etc.

Prossegue a sátira:

A sombra de Voltaire, espantada com o cortejo que o acompanha, exclama: "Não há relação alguma entre os parricidas,/ Um do outro enciumados, um contra o outro pérfido,/ Cada um vos detesta e pelo mundo sois detestado,/ Arrastando de mar em mar vossos estragos,/ Um pelo outro atropelados, verdugos e vítimas,/ Possam vossos infinitos males igualar vossos excessos,/ Cidadãos rebeldes, pretensos soberanos,/ Que fazeis um jogo com a dor dos humanos".

A sátira termina com uma nota realista em que a cabeça cortada da estátua equestre de Luís XIV de Caen adverte Luís XVI, com mais frases retiradas das obras de Voltaire: "Crede, os humanos que durante bom tempo conheci/ Merecem pouco que se queira ser seu mestre, meu filho". E acrescenta: "Não se perdem os Estados a não ser por timidez".

A marcha é fechada por Beaumarchais, que carrega as obras de Voltaire; sua mão abre a obra Pandora na cena onde esta destampa sua caixa e surgem a Constituição, os Departamentos, os Distritos, as Prefeituras; mas a esperança permanece no fundo, tendo em seu peito os retratos de Leopoldo, Gustavo, Catarina, Amadeo, dos reis da Espanha, de Nápoles e de Parma, do conde de Artois, do príncipe de Condé, etc., e como legenda ostenta este grito reverenciado por todo bom francês: "Viva o Rei”!

David também foi encarregado pela Convenção $\mathrm{Nacional}^{27}$ de preparar a "festa heroica para as honras do Panteão concedidas aos jovens Bara e Viala". Em seu relatório, David recria os elementos fundamentais do deísmo patriótico e do neoclassicismo heroico, característicos dessa religiosidade da Revolução, da qual o pintor parisiense foi grande expoente e inspirador:

Cidadãos, intérprete dos sentimentos que vos animam, procurarei desenvolvê-los e ao mesmo tempo provar ao universo inteiro que não conclamais em vão a nação inteira a uma regeneração moral; que, de um extremo a outro da França, o grito espontâneo de viver livre ou

${ }^{27}$ DAVID, J.L., Rapport sur la Fête Héroique pour les honneurs du Panthéon à décerner aux jeunes Bara et Viala (Séance du 23 messidor, an II), (11- VII-1794). morrer foi ouvido e levou o espanto à alma dos tiranos coligados.. Hoje, representantes do povo, vossos cuidados se detiveram na moral, e sentistes como é importante guiar os homens à verdade. Para atingir esse objetivo, creio que é preciso estabelecer uma comparação entre o governo arbitrário e o que fundastes, um combate entre o vício e a virtude.

Os homens são o que os governos fazem deles: essa verdade foi a de todos os tempos... Sob as leis bárbaras do despotismo, os homens, envilecidos e sem moral, não conservam sequer a forma ereta que a natureza lhes deu. Levam por toda parte a corrupção e o desalento: os braços se afastam do arado e permanecem ociosos nos palácios dos grandes; as terras estão sem cultivar, os rebanhos morrem em secos pastos e o comércio desaparece. E mais: seu jugo é tão pesado que chega a sufocar nos corações inclusive o desejo de serem pais, e a esposa amaldiçoa sua fecundidade; o amor à pátria acha-se desterrado, sua voz já não é escutada e o frio egoísmo substitui as abandonadas virtudes dos humanos: consumou-se então a desgraça dos homens; tornam-se covardes, ferozes e pérfidos, como seu governo. Humilhante verdade!, tal era o francês de antes.

Desviemos, representantes do povo, nossos olhares desse abismo que fechastes de uma vez; ofereçamos a vossos olhos um quadro mais digno de vós: apresentemos o homem ao seu autor tal como surgiu de suas divinas mãos, e divulguemos os benefícios do governo republicano.

A democracia só aceita o conselho da natureza à qual incessantemente reconduz todos os homens. Seu estudo os toma bons e amantes da justiça e da equidade. É a natureza que inspira esse nobre desprendimento que eleva as almas e as torna capazes das maiores e mais bem sucedidas iniciativas. Sob seu império, todos os pensamentos, todas as ações encontram abrigo na pátria: morrer por ela é conquistar a imortalidade...

Tu, cuja poderosa mão desfralda o céu como um véu; tu que regulas os cursos das revoluções como o das estações, faze desaparecer o despotismo da face da terra, ou antes, regenera a terra ímpia que lhe daria asilo e se armaria para sua querela: se deve haver alguma, seu crime é o mesmo que o de seus tiranos; que todos os males da guerra caiam sobre suas cabeças! E se escaparem de nossos braços vingadores, que a terra, já cansada de seus passos, recuse-lhes o abrigo e os alimentos que concede aos animais mais ferozes! Que o 
sono fuja de suas pálpebras! Que a cada instante invoquem a morte sem poder obtê-la, ou melhor, que perecendo no patíbulo, suas cinzas, ainda cheias de veneno, sejam atiradas pelo vento muito longe da terra reconquistada pela liberdade! Deus vingador, só absolva, só perdoe essas mulheres, essas crianças, esses velhos extraviados! Só proteja o humilde teto do pobre; e que o mundo inteiro repita conosco: paz nos casebres! Morte a todos os tiranos!"

Depois de comentar a liberdade e a vingança, David passa a glorificar as austeras virtudes republicanas. Nada mais clássico e de acordo com o seu credo ao mesmo tempo artístico e moral:

"Honremos os manes ainda sangrentos dos jovens heróis Bara e Viala. ${ }^{28}$ Que o triunfo que lhes concedemos traga com seu exemplo o caráter da simplicidade republicana e a augusta marca da virtude. Façamos desaparecer esse pomposo enredo que deslumbra os olhos e não enche a alma dessas deliciosas emoções que o relato das belas ações faz nascer. Deixemos esses magníficos carros aos opressores da natureza... ${ }^{29} \mathrm{Oh}$, Bara!, Oh, Agrícola Viala!; as urnas que encerram vossas cinzas serão levadas pelas mães dos guerreiros jovens; o povo francês, com as palmas da vitória na mão, será o ornamento dessa comovente cerimônia".

A seguir exorta à castidade e à simplicidade, dirigindo-se às mulheres. Fala do respeito à velhice. Incita também as mulheres a constituírem famílias honradas com os soldados da república:

A vitória vos trará amantes dignos de vós: deveis escolher entre eles; guardai-vos de desdenhar esses ilustres defensores cobertos de honrosas cicatrizes.

${ }^{28}$ As seguintes palavras são atribuídas a Agrícola Viala ao morrer: "M'an pas mancat, aço és egaou; mori per la libertat" (Procès-Verbaux du Comité d'Instruction Publique de La Convention Nationale, vol. IV, p. 624), frase que o Comitê de Instrução Pública respeitou apesar de suas ideias contrárias aos "patois" (dialetos). Chènier e Méhul completavam a colaboração de David à panteonização de Bara e Viala. Vide: CHÉNIER, M.- J., Détail des Cérémonies qui seront observées à la translation au panthéon français, de Bara et Viala. Como ocorre com tantas gestas heroicas, a historiografia descobriu a versão de que Bara foi assaltado por delinquentes comuns, e de que sua morte não teve absolutamente nada a ver com a luta revolucionária. Evidentemente, essa versão não se fez presente no contexto da cerimônia patriótica que aqui consideramos.

${ }^{29}$ É possível que David aceitasse algumas críticas e considerasse que a apoteose de Voltaire havia suscitado alguma afetação e pompa frívolas.
Na segunda parte de seu relatório, David expõe o plano da festa segundo suas ideias de quadros escultóricos e coreografias heroicas:

Às três da tarde uma salva de artilharia irrompe da ponta ocidental da ilha de Paris: é a que anuncia a cerimônia.

Então o povo se reúne no Jardim Nacional: a Convenção aparece no anfiteatro, seus integrantes envergam a indumentária de Representantes do Povo; cada um deles ostenta nas mãos o símbolo de sua missão; precede-os uma música guerreira; os cantores entoam uma estrofe do espírito da festa.

Depois do canto, o presidente da Convenção sobe à tribuna e pronuncia um discurso onde são expostos aos olhos do povo os traços heroicos de Bara e de Agrícola Viala, sua piedade filial e, em suma, todos os títulos que os tornaram merecedores das honras do Panteão...

As delegações de mães e filhos se põem em marcha formando duas colunas; o cortejo é precedido por um grande número de tambores cujos sons lúgubres e majestosos exprimem a marcha e os sentimentos de um grande povo reunido para a mais augusta das cerimônias...

De trecho em trecho, os tambores farão ouvir o seu rufar fúnebre, e a música os seus tons dilacerantes. Os cantores exprimirão nossos pêsames com inflexões de lamento; o mesmo farão os dançarinos com pantomimas lúgubres e militares.

De repente tudo será interrompido e se fará silêncio: então o povo levantará a voz e gritará três vezes consecutivas: Morreram pela pátria! Morreram pela pátria! Morreram pela pátria!...

As urnas são colocadas sobre um altar disposto no meio da praça: ao redor deste altar, jovens dançarinas executam danças fúnebres que retratam a tristeza mais profunda e cobrem as urnas com ramos de ciprestes. Neste mesmo instante, os músicos e os cantores deploram os estragos do fanatismo que nos privou desses jovens republicanos..

Tudo muda; a dor desaparece; a alegria pública corre para substituir o sentimento anterior, e o povo repete três vezes este outro grito: São imortais! São imortais! São imortais

Toca o sino e os jogos começam. 
Os tambores, com um rufar guerreiro, retumbam no ar. As dançarinas, com um passo alegre, derramam flores sobre as urnas, fazendo desaparecer os ciprestes; os dançarinos, com atitudes marciais acompanhadas pela música, celebram a glória dos dois heróis; os poetas recitam versos em sua homenagem e os jovens soldados realizam evoluções militares.

O presidente da Convenção Nacional avança em meio ao povo, pronuncia um discurso e depois as mães levam a uma de Bara para o Panteão e os filhos fazem o mesmo com a de Viala.

O presidente fecha as portas do templo e dá o sinal de partida. No retomo será observada a mesma ordem que na ida.

Uma vez tendo chegado ao Jardim Nacional, a Convenção torna a tomar lugar no anfiteatro; o presidente faz outro discurso, onde lembra às mães as lições virtuosas que devem inspirar a seus filhos desde o começo da infância, pois assim se tornarão dignos de receber um dia as honras que a pátria acaba de conceder a Bara e Viala, exorta os jovens soldados a vingar logo sua morte e a mostrar-se sempre dispostos, como eles, a entregar-se gloriosamente pela defesa da pátria.

O povo termina esta memorável e comovedora cerimônia com gritos reiterados de Viva a República!

\section{David: símbolo e dramatização}

Para Louis Réau, a influência de David e de sua escola deve ser datada de 1785 a 1824, época coincidente com as revoluções econômicas e políticas que marcam o período a nível europeu. ${ }^{1} \mathrm{O}$ grande doutrinário da estética neoclássica, considerado responsável pelo estilo pictórico de David, foi Winckelmann. Quatremere de Quincy e David, junto com Vien, seriam seus maiores difusores na França. Esta influência coincidiria com o fato de David ser o pintor "oficial" da Revolução e Quatremere de Quincy, o novo artífice do Panteão ou Basílica de Soufflot, apesar de logo abandonar a causa revolucionária, o que é diametralmente oposto à biografia política de David.

A arte antiga, tal como foi descoberta no final do século XVII (e antes do traslado e do estudo dos frisos do Partenon), era mais helenística que clássica. Contudo, na interpretação de Winckelmann, o ideal de beleza observava-se de preferência nas expressões instantâneas e nos gestos amplos. Na realização artística, isso se traduzia pela subordinação da pintura à escultura, fixando o gesto de maneira mais simples e com menos trabalho de perspectiva. Réau diz que se o século XVIII foi a época da escultura pictórica, a época de David foi a da pintura escultural.

Embora predomine em David o tema heroico com seus estereótipos obrigatórios, alguns traços realistas superarão o conjunto da obra, produzindo, talvez um pouco à margem das considerações de ordem estética, uma impressão humana importante. Esse realismo será mais dominante no Marat, mas pelo menos significativo na expressão de Pio VII no quadro da coroação de Napoleão, no olhar mortiço e apurado de Brutus, na candura generosa de Leônidas e no fulgor da Sabina situada no segundo plano do quadro.

Para Réau, precisamente este último quadro, o das Sabinas, no que diz respeito não a seu rapto, mas a sua maternidade recente, tentando separar seus irmãos e seus esposos, que lutam num combate aberto, "é o esforço maior de David no estilo heroico".

${ }^{1}$ RÉAU, Louis, La Peinture Française de 1785 à 1848, col. Histoire de l'Art, dir. André Michel, Paris, t. VIII-I, 1925, pp. 80-81. 
O realismo e a severidade presentes em boa parte da Obra de David não podem ser ignorados ante os acontecimentos e ideias da Revolução. Chega inclusive a destacar o enobrecimento e a simplicidade com que seu pincel reveste a mulher de um banqueiro do final da Revolução e do Diretório (Récamier), em contraste com o retrato da mesma mulher pintado por Gérard, onde a coqueteria e a elegância banal se superpõem. No retrato de Pio VII, Réau observa:

Captou maravilhosamente a atitude resignada, o olhar desconfiado desse 'pobre pontífice apergaminhado' que, com seu semblante sofredor e seus astutos olhos, tem o ar de uma velha raposa presa numa armadilha: procura-se involuntariamente as grades de sua jaula. $^{2}$

Réau resume assim a contribuição de David:

Reagiu contra o maneirismo em nome da simplicidade antiga, contra a libertinagem em nome do papel social da Arte. A prova de que essa reação correspondia a uma necessidade é o fato de ele ter sido aplaudido e seguido por quase todos os seus contemporâneos franceses e estrangeiros.

Mas não se pode deixar de assinalar que o estilo de David, ou pelo menos um muito parecido, também foi utilizado para ilustrar o drama dos emigrados ou exilados da Revolução. Refiro-me ao quadro de Guérin, $O$ retorno de Marco Sexto, exposto no salão de 1799, mesmo ano em que David terminava suas Sabinas.

O Leônidas nas Termópilas (1804-1814) também foi relacionado à defesa dos desfiladeiros de Argonne. Dumouriez precisamente já os denominara as Termópilas da França, e a campanha de 1792 combateu nesse lugar. Uma "explicação" do mesmo ano da exposição do quadro ${ }^{3}$ nos diz:

\section{${ }^{2}$ Idem, pp. 91,93 e 95}

${ }^{3}$ Explication du Tableau des Thermopyles, Paris, 1814. É preciso dizer que Leônidas nas Termópilas surge num momento de derrotas militares para a França. Napoleão, discernindo a lição de heroísmo, deseja que cópias do quadro sejam expostas em todas as academias militares. Description du Tableau des Sabines (extraída de artigo redigido por um amante das artes, publicado em agosto de 1810).
O quadro relata o momento em que os clarins, sentinelas à altura, advertem os primeiros movimentos do exército de Xerxes. Leônidas, rei de Esparta, sentado numa rocha em meio a seus trezentos imbatíveis, medita, com uma espécie de enternecimento, acerca da morte próxima e inevitável de todos os seus amigos.

O efeito das sabinas sobre seus esposos e irmãos empenhados na luta é o efeito da escultura sobre o traço do pincel:

Onde se encontrará um quadro que expresse melhor do que este imobilidade sucedendo a um grande movimento, ou melhor, a imobilidade absoluta substituindo a fúria transbordante que os sentimentos do coração podem conter?

Ademais, nas Sabinas, David chega a inverter o papel das mulheres nas ações heroicas. Se nos Horácios sua posição é quase oculta e bastante em segundo plano, em Brutus já adquirem posição mais destacada, porém em direção oposta ao sentimento ou ânimo enaltecido pela composição. Em compensação, nas Sabinas, são as mulheres as protagonistas da ação, imobilizando a dos homens, e ademais sua ação encarna a aprovação e a exaltação pretendidas na composição. As Sabinas também representam a inversão sociológica dos Horácios: se neste as mulheres estão passivas diante do conflito entre seus esposos e irmãos, triunfando o dever pátrio acima dos sentimentos de família - o sacrifício de uma revolução com guerra civil -, nas Sabinas as mulheres tomam a iniciativa e, exibindo sua piedade familiar - os filhos -, contêm o combate pelas respectivas pátrias. Os sentimentos, antes relegados pelo dever pátrio, acabam assim triunfando em nome da paz.

A inspiração de David para seus Horácios parece ter sido a tragédia de Corneille, tal como foi encenada em 1782, embora em Corneille o papel das mulheres seja mais importante. A primeira ideia de David era pintar (deixou um esboço) o pai dos Horácios desculpando o crime de seu filho, que mata a irmã por ser esposa de um Curiácio.

Os Horácios enalteciam e profetizavam uma humanidade regenerada através do heroísmo inspirado nas façanhas da antiguidade. A sensação que

PÉRON, Alexandre, Examen du Tableau des Horaces, Paris, 1839. O Juramento dos Horáclos é de 1784. 
o quadro causou na própria Roma ampliou-se em Paris. Alexandre Péron comentava em 1839 a influência dos Horácios na França ${ }^{4}$ :

... depois do entusiasmo suscitado por sua exposição em Paris, seu efeito mais imediato foi uma mudança súbita e completa em nossos gostos, usos e costumes. A partir deste momento tudo mudou em nossos ateliês, em nossas fábricas e indústrias: todo mundo quis ter casas, móveis e roupas à antiga: e essa revolução do gosto, disseminada por todos os estrangeiros que vieram nos visitar e se contagiaram com nossa produção, nosso tom e nossas modas, transformou-se num fenômeno universal.

A segunda regeneração, profetizada pela primeira (a das artes), promulgando os princípios de uma nova ordem social, mudaria, através da mais assombrosa das revoluções políticas, toda a face da sociedade francesa, baseada desde então nos imprescritíveis direitos à liberdade e à igualdade civis, e se irradiaria ao mundo todo.

Diante de tudo isso, que não é senão a própria história, que outro artista além de David, revestido de um caráter (ia dizendo de um sacerdócio) de certa forma providencial, podia exercer maior influência sobre toda a época?... Que destino maior haveria para a arte além de proclamar e recordar ao homem a sua própria dignidade, fazê-lo melhor em sociedade e maior para a pátria!

A vocação moral e patriótica dessa arte davidiana é registrada por uma sátira motivada pela aparente deserção de David ao unir-se aos projetos napoleônicos ${ }^{5}$ :

...somos uns canalhas! Quando penso naqueles dias felizes da república quando todo um povo, ébrio de liberdade, comprimia-se em multidões ao redor de um carro antigo sobre o qual eram vistas encantadoras deusas, belas como a esperança, vestidas como as virgens gregas!... Havíamos rejuvenescido o mundo; tínhamos tirado quatro mil anos de cima de nossos ombros!

${ }^{4}$ Cf. nota 3, pp. 26 e 27. Nos Horácios a atitude ereta, ascendente, do pai e dos filhos, com a ponta das espadas como vértice de um cimo simbólico, contrasta com a prostração das mulheres, com cores mais esmaecidas. Em troca, o manto vermelho do pai e a camisa do filho primogênito destacam-se muito mais. O palco parece o de um pequeno teatro, com seu amplo lajeado e suas colunas ao fundo.

${ }^{5}$ Le Tableau du Sacre, peça de teatro, s.l.n.f.
Porque, e este é um aspecto contextual importante do neoclassicismo e do amor à antiguidade na época que tratamos, o regresso artístico e político ao passado não era interpretado tanto como uma nostalgia de velho mas como a descoberta da verdadeira juventude, a das civilizações de maior frescor. A identificação dos jovens às épocas antigas era feita em nome de uma maior espontaneidade, expressividade e inclusive vaidade para alguns, de uma época considerada mais própria à vida dos jovens: com seus jogos, combates e façanhas, suas viagens e danças, seus sonhos e seus ideais.

Renouvier concluía, acerca da religiosidade da arte revolucionária, de maneira contundente ${ }^{6}$ :

A Revolução, que em suas origens era plenamente filosófica e plenamente política, suscitou tantos sentimentos novos que lhe foi preciso também tomar-se religiosa, no sentido de encontrar para a arte um ideal e um foco de inspiração. As concepções mais elevadas do espírito humano, as virtudes morais e cívicas e os dons da Natureza foram tomados em seus sentidos figurados e em suas formas alegóricas, substituindo as personalidades, os ídolos e as superstições do passado.

Starobinsk $^{7}$ registra com singular compreensão todas as representações artísticas da Revolução. Destaca as conexões entre as diversas obras neoclássicas e seu significado no contexto revolucionário: a antiguidade heroica com suas formas limpas e seus lugares arquetípicos. No entanto, não ressalta muito a ação gestual da arte na linguagem da revolução: o papel de acréscimo ou soldadura significativa desempenhado por algumas obras na retórica da ação revolucionária. Nesse sentido não basta comentar as influências recebidas e dadas por David, mesmo com detalhes que o vinculem às ações da Revolução (a relação entre os Juramentos, dos Horácios, do Jeu de Paume, etc.); é preciso, ademais, considerar sua obra como um efeito litúrgico, como pertencente a uma cerimônia, em especial a obra que se destinou explicitamente às cerimônias ou apoteoses da Revolução.

${ }^{6}$ RENOUVIER, J., Histoire de l'Art pendant la Révolution, Paris, 1863, p.391.

${ }^{7}$ STAROBINSKI, Jean, 1789, Les Emblèmes de la Raison, Paris, 1979. 
A revolução na arte (o novo romantismo) não se produziria na arte que mais se pôs a serviço da Revolução Francesa. Pode-se inclusive dizer que o novo romantismo surgiu na sua periferia. Entretanto, em alguns casos, a Revolução é um código para se entender esse fenômeno. O mais notável, como nos faz ver Starobinski, ${ }^{8}$ é o de Goya. Este pintor aragonês expressaria a "perversão" da revolução, a corrupção do ideário e da prática revolucionária, dos direitos do homem e da fraternidade. As trevas, a racionalidade demente e o desastre violento substituiriam um mundo de luzes brilhantes e formas vivas. E isso não apenas por retratar a revolução como guerra de opressão, mas também por chegar ao próprio fundo dos paradoxos e das armadilhas da luta pela liberdade e pelo poder. Quando David em seu exílio belga parece retroceder a uma espécie de teimosia infantil com o academismo neoclássico, Goya já havia produzido com a sua arte, um gesto novo ante a barbárie, uma nova defesa.

Starobinski ${ }^{9}$ compara o Marat de David ao personagem central, cheio de luz e horror, dos Fuzilamentos de 3 de maio de 1808 em Madri, uma das poucas comparações entre esses dois pintores. Mas, neste caso, a inflexão vigorosa que David imprime a sua trajetória, bem como a coragem que poucas vezes pode ser encontrada num simples quadro, como ocorre no de Goya, levam Starobinski a dizer:

Somente um Goya (e muitas vezes um David) fizeram aparecer a invisível presença da 'liberdade moral'. Já que a mais alta liberdade na invenção das formas como no sentimento interior - só é dada aos artistas que aceitaram as fatalidades da matéria e dos fatos e souberam responder ao seu desafio com lealdade.

Mas junto com o David do Marat existe também o David das apoteoses teatrais da Revolução. O David, por exemplo, da festa de 10 de agosto de 1793, motivada pela nova Constituição francesa: uma estátua da Natureza sobre as ruínas da Bastilha, com fontes nos seios; um cálice de "forma antiga" enchia-se com as "águas da natureza" que eram bebidas à saúde da República; festejos com decorações alusivas ao ruralismo e à nova legislação; "igualdade sagrada" na distribuição cerimonial dos cidadãos; respeito para os cegos e as crianças abandonadas; a razão aperfeiçoando o

\section{${ }^{8}$ Idem, op. cit.}

${ }^{9}$ Idem, p. 134. que a natureza deixa imperfeito, a "desgraça consolada e honrada"; a pantomima de uma ação moral da Antiguidade (Biton e Cleobis); a morte evocada em sua forma heroica, não na fúnebre; um arco de triunfo erigido à coragem das mulheres na Revolução: "Que espetáculo!, a fragilidade do sexo e o heroísmo da coragem! Ó, liberdade, estes são os teus milagres!”; mulheres coroadas de louros, para adornar a coragem e a vitória, ao invés de flores que adornariam apenas sua beleza; fuzis repletos de bonés frígios, faixas tricolores, guirlandas de flores, desenhos das obras da Revolução... ; a queima dos símbolos do antigo regime $;^{10}$ três mil pássaros voando com bandeirolas tricolores e os dizeres; somos livres, imitai-nos; uma estátua colossal representando o povo francês vencendo o monstro do federalismo, um "templo fúnebre cuja decoração, parecida com a dos monumentos cuja beleza a história das artes e das repúblicas nos transmitiu, esperava as cinzas de nossos defensores". Entre colunas, álamos, ${ }^{11}$ pórticos, estátuas, pássaros, cálices, homens e mulheres escolhidos por sua coragem, toda a antiguidade heroica é evocada por David para tornar sublime o destino da república francesa e o sentimento de liberdade e fraternidade que sua constituição estabelecera como "dogma político". ${ }^{12}$

Não era uma cerimônia, mas um culto a que todos os corações haviam cedido com entusiasmo, que haviam idolatrado. ${ }^{13}$

Le Serment du leu de Paume contém várias referências significativas para a relação entre a religião e a revolução na França. Tal como destaca Bordes, ${ }^{14}$ David atribui muita importância à presença eclesiástica na assembleia de Versalhes. Os três homens que ocupam o centro da composição - conforme à realidade, segundo mais de uma testemunha - são

${ }^{10}$ Dr. ROBINET, Le Mouvement Religieux à Paris Pendant la Révolution, Paris, 1896, pp. 546 e segs. David também propusera à Convenção a realização de uma gigantesca estátua dedicada ao povo francês abatendo a monarquia. O editor de Révolutions de Paris $\left(\mathrm{n}^{\circ}\right.$ 217,10-18 do frimário, ano II = 30-XI a 8-XII de 1793) sugeriu a seguinte inscrição para esse monumento: "O povo, devorador de reis" em alusão à de Homero "os reis, devoradores de povos".

${ }^{11} \mathrm{O}$ peuplier é quase sempre um choupo-preto (populus nigra); contudo, às vezes o traduzo como álamo (populus alba), por corresponder à acepção mais geral (incluindo vários tipos) segundo o uso comum na linguagem literária.

12 ROBINET, op. cit., p. 553.

${ }^{13}$ Idem, p. 550.

${ }^{14}$ BORDES, Ph., Le Serment du Jeu de Paume de Jacques-Louis David, Paris, 1983. 
dom Gerle (cartuxo), Grégoire (sacerdote católico) e Rabaut Saint-Etienne (ministro protestante), com Bailly presidindo o ato numa postura não reconhecida com exatidão pelas testemunhas da reunião. Esse grupo, "que encarna a ideia de confraternização apoiada pelo pensamento deísta do iluminismo, representa a Divindade diante da qual os deputados que juram se comprometem com a verdade. E permite que o pintor tome partido pelo clero constitucional, numa época em que a Assembleia acabava de ser condenada pelo Papa por ter imposto aos sacerdotes, transformados em funcionários públicos, a obrigação de prestar o juramento exigido pela Constituição. David introduziu também um detalhe para fustigar a Igreja romana e o alto clero aristocrático: na parte superior esquerda, vê-se o raio que atinge a capela do castelo de Versalhes que, esclareçamos, não é visível da sala do Jeu de Paume".

O mesmo Bordes assinala, junto com esse espírito de confraternização, o de tolerância da individualidade, presente na composição de David. Tolerância que ficará cada vez mais difícil e travestida no curso da Revolução. Assim, o abade Sieyes aparece em atitude inflexível ou mal-humorada, Martin-Dauch mostrando sua auto-exclusão do juramento, Robespierre num gesto arrebatado...

Villette comentou o esboço de Le Sennent du leu de Paume ${ }^{15}$ enaltecendo a arte premonitória de David, a estética classicista que tem afinidades com as virtudes da revolução e queixando-se da falta de êmulos para o mestre:

Apenas David, cujo fogoso patriotismo já dirigia as ideias muito tempo antes da revolução, poderia nos apresentar com tanta vida $L e$ Serment du Jeu de Paume. Um local simples e sem acessórios, os muros vazios, nos trazem à lembrança a austeridade do Lácio; poderia parecer que essa moção tivesse sido jurada no Capitólio e não em Versalhes.

Insto ao grande mestre para que suprima o papel que tem em sua mão o presidente da Assembleia. Foi levando uma das mãos ao seu coração, e erguendo a outra, que Bailly prestou o memorável

${ }^{15}$ VILLETTE, Charles, Lettres Choisies, Paris, 1792, pp. 238 e 245. (Salão de outubro de 1791.) juramento. Foi o impulso da alma, o primeiro grito da Liberdade, e que por certo não escrevera na véspera...

Fica-se um pouco surpreso ao ver no Salão (outubro de 1791) apenas um quadro com os grandes acontecimentos da Revolução. Será que os artistas ainda não se elevaram a sua altura? Paris não oferece um único monumento que fale de sua liberdade, de sua glória... Às vezes nos afligimos ao pensar que os déspotas e os tiranos fizeram mais pelo esplendor das artes do que os próprios heróis da Liberdade.

Anteriormente, David expusera no salão de 1789 o quadro "Os lictores levando a Brutus os corpos de seu filhos”. A Bastilha fora atacada e destruída havia pouco tempo. Brutus, com sua atitude, seu drama, sua política e suas convicções já era a perfeita antítese de Luís XVI. Sua resolução, sua gravidade, seu amor severo, seu republicanismo e seu patriotismo eram avessos às hesitações, deferências, ridículos, claudicações e compromissos de sangue do monarca francês.

O tema de "Brutus meditando perante a estátua de Roma à qual sacrificou a vida de seus filhos criminosos contra a pátria e a liberdade" atrairia até mesmo o bolchevismo de Plekhanov que, na primeira década do século XX, aconselhava a visita ao Louvre para "inclinar-se diante de Brutus". 16

Da luz do juramento dos Horácios e do Jeu de Paume, passamos à penumbra da luta pela liberdade e ao sacrifício da família pela pátria. $\mathrm{O}$ Brutus de David, com seus olhos escuros que se destacam na penumbra, sua expressão de tristeza consciente, seu gesto vacilante e sua tensão nas extremidades, surgiu como um dos áugures mais penetrantes da Revolução, como uma concepção "tenebrosa da liberdade" para uns e um chamamento ao heroísmo pátrio para outros: a deusa Roma entre Brutus e o cadáver de um filho seu. A maior reação das mulheres, comparando com a dos Horácios, já se aproxima da inversão total de seu papel nas Sabinas. Essas mulheres, parentes de sangue dos inimigos de seus esposos, personificam, com um total senso da irremediabilidade, a oposição entre os deveres pátrios e o amor conjugal e familiar. David as utilizará para a conjuração da

${ }^{16}$ HUMBERT, Agnes, Louis David. Peintre et Conventionnel, Paris, 1936. 
paz $^{17}$ Brutus tem nas mãos o papel da conspiração para restaurar a monarquia de Tarquímio, presságio também do motivo do quadro dedicado a Marat, que também guarda nas mãos o testemunho escrito da traição de Charlotte Corday.

Fora a questão das influências ocasionais, não há dúvida de que o contexto filosófico-político do Brutus de David está relacionado, no que tange à Revolução, com a interpretação dramática proporcionada por Voltaire. Seu Brutus é o mais próximo do republicanismo exibido como drama, como gesto que dialoga com a arte e como conceito popular de liberdade.

A popularidade da tragédia Brutus de Voltaire foi crescente até que na Revolução tomou-se uma das peças teatrais favoritas do público francês. ${ }^{18}$ Voltaire inspirou-se em alguns episódios da vida de Lucius Junius Brutus, cônsul de Roma no século VI antes de Cristo. Mais do que o argumento da tragédia, o que pareceu atrair a atenção do público foram as suas "árias políticas". Neste sentido, Besterman ${ }^{19}$ assinala: "quando Brutus disse que a glória do senado consistia em representar o povo, afirmou a ideia de democracia de uma maneira nunca ouvida num palco francês, ideia explicitamente escandida. A noção de uma justiça pública que transcendia a autoridade era ouvida pela primeira vez" (em 1729, quando Voltaire tinha trinta e seis anos).

Conheceis Brutus, e ousais consolá-lo?

Pensai que um novo ataque nos preparam,

Só de Roma me ocupo: suas coisas me bastam.

17 CROW, Th.E., Jacques-Louis David's Oath of the Horatii: Painting and PreRevolutionary Radicalism in France, tese de doutorado, Universidade da Califórnia, Los Angeles, 1978. Ademais, é curioso saber que, quando David fez o Brutus, na verdade the havia sido encomendado um Coriolano. Se no primeiro o amor à família é superado pelo amor à pátria, no segundo é o contrário; além do que, as mulheres têm, neste, uma função mais importante no desenrolar dos fatos. Esse tema só seria recriado por David mais tarde,

com as Sabinas.
${ }^{18}$ LEITH, James A., "Les trois apothéoses de Voltaire", em Annales Historiques de La Révolution Française, no 236, 1979, p. 204: o Brutus de Voltaire foi encenado em Paris pelo menos onze vezes em 1790, 25 em 1791, 36 em 1792, 30 em 1793, vinte em 1794 e depois, no período final da Convenção e no Diretório, muito menos.

${ }^{19}$ BESTERMAN, Th., Voltaire, Londres, 1969, pp. 121-122.
Vamos, que neste tempo de dor os Romanos,

Ocupem o lugar do filho perdido por eles;

Que ao menos possa acabar minha vida tão deplorável

Vingando-me, como ele deveria, do inimigo execrável. ${ }^{20}$

$\mathrm{Na}$ última cena, a prioridade do amor pátrio é consagrada como numa fórmula:

Roma é livre. Isso basta... Demos graças aos deuses.

Na cena aparecem quatro litores transportando só o corpo de Titus, sem o do outro filho, como no quadro de David. Este outro, que se suicida, é eliminado do desenlace moral da tragédia de Voltaire. Antes de cair o pano, Brutus "cai sobre uma cadeira de braços", ao passo que, no quadro de David, Brutus permanece bastante ereto numa cadeira e denotando certa tensão.

Seu remorso o arranca de mim. Oh, Roma! Oh, meu país!

Próculus... à morte meu filho conduzis.

Levanta-te, triste objeto, de horror e de ternura.

Levanta-te, apoio querido de minha longa caminhada:

Vem, abraça teu pai: ele teve que te condenar;

Mas se não fosse Brutus, me disporia a te perdoar.

Minhas lágrimas, falando contigo, inundam teu próprio rosto:

Vê, leva a teu suplício uma coragem que te enaltece;

Vê, não espere mais, sê mais de Roma que meu;

E que Roma te admire, vingando-se de ti. ${ }^{21}$

Brutus, "se não fosse Brutus", é um destino, o destino de uma revolução, o sacrifício do insacrificável, a não ser pela pátria, a única que enaltece aquele que morre por seu amor e contra ela. Castigado e redimido.

${ }^{20}$ VOLTAIRE, Brutus, $5^{\circ}$ Ato, cenas IX e X, Paris, 1794. Encenada pela primeira vez em 11 de dezembro de 1730, tornou a estrear no teatro da Nação em 17 de novembro de 1790 e no da República em 1792.

${ }^{21}$ Idem, último ato, cena VIII. 
Essa dupla sensação não se pode esquecer presenciando as execuções de Danton, de Robespierre, de Mme. Roland, de tantos radicais e moderados, e também o severo e disciplinado guilhotinamento de Luís Capeto. Quase nunca se esquece que o patíbulo erguido pela França para sua regeneração destina-se aos franceses. Em última instância, o próprio patriotismo enobrece o sangue do filho justiçado.

O Marat de David é o quadro de efeitos mais sóbrios e fortes de toda sua coleção revolucionária, como já dizíamos ao compará-lo aos efeitos de Goya. Deixemos que o próprio David nos fale dele ${ }^{22}$ :

$\mathrm{Na}$ véspera da morte de Marat, a Sociedade dos Jacobinos nos enviou, a Maure e a mim, para saber dele. Encontrei-o instalado de tal maneira que me impressionou. Tinha a seu lado um tabuleiro de madeira, em cima do qual estavam a tinta e o papel, e sua mão, saindo da banheira, escrevia seus últimos pensamentos para o bemestar e a salvação do povo. Ontem, o cirurgião que embalsamou seu corpo perguntou-me de que maneira iríamos expô-lo aos olhares do povo na igreja dos Cordeliers.

Algumas partes de seu corpo não podem de forma alguma ficar descobertas, já que, como sabeis, tinha uma espécie de lepra e seu sangue ficava queimado; mas pareceu-me que seria interessante mostrá-lo na atitude em que o encontrei, escrevendo para a felicidade do povo.

Assim o pintou. Depois, ao doar o quadro à Convenção, diria ${ }^{23}$ :

Cidadãos, o povo reclamava seu amigo, sua voz desolada se fazia ouvir, provocando minha arte; o povo queria ver uma vez mais as feições de seu fiel amigo: 'David! Toma teus pincéis' - exclamou, 'vem a nosso amigo, vem a Marat; que seus inimigos vencidos empalideçam ainda mais ao ver suas desfiguradas feições, leva-os a invejar a sorte daquele que não puderam corromper e que tiveram a covardia de assassinar'. Ouvi a voz do povo, obedeci... É a vós, colegas meus, a quem ofereço a homenagem de meus pincéis; vossos olhares, ao percorrer as feições lívidas e ensanguentadas de Marat, vos recordarão suas virtudes, que jamais devem deixar de ser as vossas.

${ }^{22}$ Gazette nationale ou Le Moniteur Universel, $\mathrm{n}^{\circ} 198,17-\mathrm{VII}-1793$.

${ }^{23}$ DAVID, J.-L., Discours prononcé à la Convention Nationale par... député de Paris, en lui offrant le tableau représentant Marat assassiné, 24 do brumário, ano II = 14-XI-1793.
Cidadãos, quando nossos tiranos e sua profusão de erros levavam a opinião pública à perdição, a opinião pública levou Mirabeau ao Panteão. Hoje em dia, as virtudes e os esforços do Povo destruíram o prestígio; a verdade já não é oculta, diante dela a glória do amigo dos reis se dissipa como uma sombra; que o vício, que a desfaçatez fuja do Panteão; o povo exige aquele que nunca o enganou. Eu voto pelas honras do Panteão para Marat. ${ }^{24}$

Contra um fundo ao mesmo tempo de um vigor e de uma leveza admiráveis, que nada transtorna, obtendo uma simplicidade sapientíssima, destaca-se com luminosidade o corpo inanimado de Marat... Os detalhes acessórios são tratados com liberdade e sobriedade tais que deixam ao personagem em si todo o interesse da obra.

David nos mostra os sentimentos que o animavam quando empregava os recursos de sua arte para despertar o horror e a piedade: concentrando nessa figura de Marat toda a força de sua imaginação e de seu talento para atingir uma simplicidade heroica. Nenhum detalhe inútil pode distrair o espírito da terrível emoção que o artista quis inspirar. Tudo concorre para que a piedade, e inclusive a vingança, ergam-se em favor da vítima e assim se animem no coração do espectador as paixões enérgicas e selvagens da Revolução.

Com que procedimentos obteve David tal resultado? Aqui o artista abandonou sua maneira habitual de pintar. Já não existem aquelas pinceladas justapostas que buscam modelar as formas combinando o tom e o traço, nem tampouco aqueles azuis ou vermelhos... Soube, sem sair da gama do cinza do luto e da dor, envolver tudo com uma coloração cálida e modelar com firmeza as formas de seu rosto, mergulhando seus contornos num meio-tom muito belo... ${ }^{25}$

\footnotetext{
${ }^{24}$ Uma anedota avalia assim a corrupção e a panteonização no imaginário de David: Fabre d'Eglantine afirmava não haver homem algum que não pudesse ser corrompido (possivelmente depois da fácil experiência consigo mesmo), pois todos possuíam algum ponto fraco. "É só uma questão de atacar esse ponto. David exclamou: 'E crês que eu posso ser corrompido'? 'Mais facilmente que outro', respondeu o poeta. 'E como?' inquiriu David. 'Prometendo-te as honras do Panteão, concedidas durante tua vida'. David viu-se obrigado a admitir que, de fato, este era o lado por onde podia ser corrompido". MIETTE DE VILLARS, M., Mémoires de David, peintre et Député à la Convention, Paris, 1850, p. 154.

${ }^{25}$ Notice sur le Marat de Louis David, Paris, 1867, p. 21.
} 


\section{O culto republicano}

A devoção aos ideais republicanos gerou vários cultos com suas próprias representações, hinos e orações, que foram considerados sublimes, afetados, artísticos, oportunistas ou pedantes. Como em qualquer outra manifestação de religiosidade ou devoção, a redução de sua abrangência a apenas uma destas qualificações também é fruto de um equívoco. Determinados historiadores cederam à tarefa fácil da caricatura ou da intenção política oculta. Seria um grave erro esquecer que tais manifestações surgiram no bojo de uma revolução, quer dizer, no decorrer de mudanças suficientemente fortes para quem sabe perecer ou modificar-se profundamente durante o seu transcurso. Assim, só é provável interpretar todos os sentidos que puderam ter os cultos revolucionários levando-se em conta o fato da Revolução, fato por sua vez com complicações psicológicas, econômicas, políticas, etc. Em outras palavras: o gesto feito quando existe emoção não é o gesto feito quando a emoção não existe, embora ambos sejam idênticos na forma.

Já foi dito que a "Revolução pode ser comparada a um grande drama lírico, libreto de M.-J. Chénier, música de Gossec, cenário de David; dito seja sem má intenção". ${ }^{1}$ Embora tenha havido mais autores, é verdade que esses três podem ser considerados os mais destacados. A David, já nos referimos. É difícil falar de Chénier, de quem se falou demais em virtude da história de seu irmão André. Limitemo-nos a saber que Marie-Joseph Chénier escreveu a letra de numerosos hinos da Revolução, refletindo quase sempre um deísmo patriótico e semelhante ao republicanismo heroico de David. François Joseph Gossec (Gossé) havia sido músico da corte, brilhando pela gravidade e pelo lirismo de sua música, muito melódica. Durante a Revolução compôs muitas celebrações: 14 de julho, Ser Supremo, Liberdade, Igualdade, Reunião... Compôs também os corais e cantos para as apoteoses de Voltaire e Rousseau, bem como marchas e cantos fúnebres ou "lúgubres" para enterros e comemorações patrióticas."

${ }^{1}$ CONSTANT, Pierre, Les Hymnes et Chansons de la Révolution, Paris, 1904, p. 94.

${ }^{2}$ Ver art. Gossec em FÉTIS, F.J. de, Biographie universelle des musiciens, Paris, 1862.
A ideia principal do republicanismo francês é a liberdade. "Antes de te conhecer, o homem ignora a vida", são as palavras de M.-J. Chénier no hino composto por Gossec. ${ }^{3}$ Junto com esta ideia se estabelece uma sociedade considerada mais conforme à razão e à natureza, baseada em discriminações respeitáveis de idade e sexo, e de amor pela família. ${ }^{4}$ Nesse sentido, é preciso recordar que a Convenção observou uma política de proteção e apoio à família, algo que se revela na plástica teatral de David. Até mesmo nos projetos de extensão sistemática da educação pública, a Convenção procurou respeitar uma esfera familiar considerada imprescindível para a educação e a instrução:

Guardemo-nos de afastar uma criança dos cuidados de sua mãe, das brincadeiras de seus irmãos e irmãs, do trabalho e da voz de seu pai. Nossa instrução pública deve colocar-se no meio disto tudo; e esses seres jovens, sem sair do seio de sua família, unir-se-ão alegremente a seus vizinhos para irem todos juntos à escola da igualdade.

A liberdade, os laços do amor familiar e fraterno, a pátria e sua nova tradução da imortalidade e de Deus: eis os fundamentos da religiosidade e do culto republicanos.

Um catecismo publicado em "Londres" em 1789 apresentava a verdadeira religião como o culto à pátria, mostrando-a como única divindade tutelar. ${ }^{6}$ Aceitando que a religião era só um "instrumento da política", o amor às leis seria o sentimento religioso por excelência.

Mas o culto pátrio queria ser mais excelso e místico. Camille Desmoulins o expõe com um deísmo intenso e de confirmação da tradição deísta dos ilustrados ${ }^{7}$ :

Trata-se o ateísmo de delírio. É razoável tratá-lo assim. Sim, existe um Deus, vemo-lo claramente contemplando todo o universo; mas o

${ }^{3}$ CHÉNIER, DUSAUSOIR et alii., Office des Décades ou Discours, Hymnes et Prières en usage dans les Temples de la Raison, Paris, germinal, II (março-abril, 1794).

${ }^{4}$ HENRIQUEZ, L.M., Histoires et Morales Choisles pour chaque mois de l' année républicaine, Paris, 1794-95.

${ }^{5}$ Procès-Verbaux du Comité d'Instruction Publique de la Convention Nationale, Paris, 1894, t. II, p. 133 .

${ }^{6}$ Catéchisme d'un peuple libre, Londres, 1789.

${ }^{7}$ DESMOULINS, Camille, Opuscules de l' an premier de la liberté, Paris, s.d. [1790], pp. 20 e 65. 
vemos como filhos desamparados, abandonados, que procuram ver o seu pai. É certo que têm um pai; mas o reclamam em vão, esse pai não aparece de maneira alguma.

Em vão procuro o culto que lhe pode ser mais agradável; ele não o manifesta a mim com nenhum sinal e sua fúria se abate tanto sobre nossas igrejas como sobre nossas mesquitas. Não é Deus que tem necessidade da religião, são os homens. Deus não necessita de incenso, de procissões e de orações, mas nós necessitamos de esperança, consolo e compensação. Considerando-se que, aos olhos de Deus, todos os cultos e todas as religiões são igualmente aceitáveis e indiferentes, não teríamos direito a uma religião nacional?

Ao invés de uma religião feliz, amiga dos prazeres, das mulheres, da população e da liberdade, de uma religião na qual a dança, os espetáculos e as festas fizessem parte do culto, como eram a dos gregos e a dos romanos, temos uma religião triste, austera, amiga da Inquisição, dos reis, dos monges e do cilício, uma religião que deseja a pobreza, não só de bens como também de espírito, inimiga dos pródigos e dos encantos da natureza, que reprova a felicidade, que quer que se ande a contrapelo, como fazem os Carmelitas, que se viva como um verdadeiro mocho, como os Antônios, os Paulos, os Hilariões...; que só promete suas recompensas à pobreza e à dor, que, em suma, só serve para os hospitais. Podemos suportar sua máxima antinacional? Obedecei aos tiranos: Subditi estote non tantum bonis e modestis sed etiam discolis. O paganismo tinha tudo a seu favor, exceto a razão, mas a razão não está mais satisfeita com nossa teologia; e, loucura por loucura, prefiro um Hércules lutando com o grande javali de Erimanto do que um Jesus de Nazaré afogando dois mil porcos...

Se o povo tem necessidade de uma religião, o filósofo, o homem sensível e honesto, tem ainda mais. Vede que esforços fizeram Platão, Cícero e Jean-Jacques para nos persuadir da imortalidade. Na França há um milhão de teístas, dizia há 25 anos atrás o patriarca Ferney; de lá para cá, essa quantidade vem aumentando infinitamente, e é muito provável que o teísmo chegue a ser a religião católica, quer dizer, universal... O templo do teísta é o universo; mas pedimos, ademais, igrejas, quer dizer, lugares para as assembleias de oito milhões de teístas. Despojada das mentiras dos demais cultos, dos quais todos desfiguraram a divindade, só conservará o que possuem de augusto: o reconhecimento de um Ser Supremo e a ideia de sua justiça, inseparável da recompensa para os bons e do castigo para os maus. O filósofo exerce o sacerdócio dessa religião com uma vantagem para o povo: não lhe inflige dízimos nem lhe arrebata doações pias, nem abadias, nem priorados, nem serviços pessoais, nem pensões de benefícios..

Não faltarão a esse culto cerimônias religiosas e emotivas. Que a Igreja restitua tudo que subtraiu ao paganismo, que não é senão o teísmo alterado, e em lugar da procissão de rogações, teremos a procissão da festa de Palas; em lugar da água benta, a água lustral em lugar da hóstia consagrada, os ágapes, as refeições em comum dos Pitagóricos; em lugar dessa pátena de cobre ou de prata que nos apresentam, teremos a antiga cerimônia do beijo da paz, instituição agradabilíssima para os que sabiam colocar-se vantajosamente. Temos algo mais piedoso que a oração de Epíteto ou o hino de Cleanto? Quem não se sente pleno de recolhimento e de devoção quando, na ópera de Alceste, escuta a oração do sumo sacerdote, quando em Notre-Dame escuta "O Salutaris" de Gossec? Não há uma só de nossas festas que não seja uma imitação das festas pagãs. E mais: o que mais se imitou dessas festas foi a sua extravagância, sem conservar seu objetivo moral. Tomemos, por exemplo, essas satumálias (satumais) tão lamentadas, às quais sucedeu o carnaval. Nas satumais, os pagãos se comportavam como se o mundo fosse acabar. Era uma festa comemorativa, instituída para recordar a igualdade original, uma espécie de declaração festiva dos direitos do homem. Tudo queria representar a aniquilação futura das sociedades. Já não havia tribunais, escolas, senado nem guerra. Todos os estados das pessoas se achavam confundidos. Os pobres participavam dos banquetes sem distinção de posição social. Os senhores trocavam suas vestes pelas dos escravos e, por sua vez, os serviam. As dívidas eram pagas, assim como as mensalidades das amas e os aluguéis dos pobres. O que disse já foi suficiente para que o clero se dê conta de que está enganado ao fazer prevalecer a pretensa necessidade de sua moral, da qual é possível prescindir com vantagem. Deixo ao abade Fauchet a elaboração de um bonito livro sobre isso, que nos dê um tratado de religião e que dê o toque final no deus nacional que tão felizmente concebeu.

É assim que Desmoulins acaba invocando a cumplicidade de Fauchet como ideólogo de uma religião nacional, sem que seu cristianismo 
radicalmente evangélico representasse ameaça alguma para o deísmo patriótico.

Levando-se em conta a presença do complemento deísta e de realce dos fundamentos da moral republicana, passemos a considerar as celebrações mais destacadas do culto republicano.

A festa da Federação nacional, proposta por Bailly, ${ }^{8}$ foi elogiada por todo mundo e representou uma celebração solidária, antes de a revolução se tomar mais exigente para com a realeza e as elites sociais. O rei, vacilante, não aproveitou a ocasião para firmar sua posição, embora tenha jurado publicamente respeitar a Constituição:

Restif de la Bretonne foi dos que melhor lembrança conservaram da festa:

Eu observara o trabalho dos cidadãos e o altar da Pátria me evocara os belos dias da Grécia antiga. Sem ser devoto, creio num Serprincípio. Prosternei-me; minha alma se elevou até ele e roguei por minha nação:

Fonte de vida! Contempla a união de teus filhos! Faz com que o sol, em seu percurso, não encontre nada maior do que o nome francês!

Caminhava, concentrado em meus pensamentos, conjecturando sobre os acontecimentos futuros, às vezes com esperança, às vezes com calafrios. Depois, recordei a história dos tempos passados. Via a marcha dos governos, que não pára nunca, incline-se ela ao despotismo ou à liberdade. Depois perguntei-me se os homens podiam criar o bem e o mal... Perdia-me nessas ideias morais e

${ }^{8}$ Jean Silvain Bailly viveu 57 anos a partir de 15 de setembro de 1736 . Duas vezes prefeito de Paris, deputado e presidente da Assembleia Nacional, membro das Academias de Ciências e Letras, e da Academia Francesa, autor de um tratado de astronomia e de um ensaio sobre os contos e as lendas, foi executado com certa crueldade por ter sido declarado culpado da matança do Champ de Mars. Em suas memórias relata o seguinte: "hoje ocorreu em Versalhes um fato que me afligiu profundamente. Um homem, condenado à roda por ter assassinado o pai, foi libertado pelo povo, que gritava graça no momento de sua execução; assim, o parricida escapou da vingança das leis. Uma mulher que se sentiu indignada com o acontecido e externou seu descontentamento esteve prestes a ser enforcada, vítima da fúria popular. Essa violação da lei e esse direito de indulto exercido pelo povo, e exercido ante o mais horrível dos crimes, fizeram-me estremecer; neles vi o pressagio das consequências mais funestas...”(t. II, p. 256). políticas, não sabendo, ou antes considerando-me sabedor de que os grandes abalos produzem sempre um grande mal para as almas fracas, que constituem a massa do gênero humano.

Jamais houve uma cerimônia tão grande e majestosa... Emocionoume, comoveu-me. Creio que o desditoso Luís também sentiu assim. Acreditei ter visto lágrimas em seus olhos. Seriam de ternura?

Acabou com um grande júbilo essa magna jornada, a mais bela da Revolução!...9

A cerimônia ou festa da liberdade realizada em homenagem aos suíços do regimento de Chateauvieux, que se opuseram às ordens de repressão contra o povo, revela bem, em comparação com a apoteose de Voltaire, a continuidade e o progresso da devoção patriótica, festejando todas as ações suscetíveis desta devoção. A festa teve lugar em 15 de abril de $1792^{10}$ :

Apresentamos várias vezes para os nossos leitores os interessantes quadros das festas públicas. Esses grandes espetáculos que a pátria oferece a seus filhos são dignos da mais atenta observação, já que seu objetivo, seus preparativos e até os seus ínfimos detalhes revelam com acerto o espírito do governo que os ordena: mas o povo que os recebe é ainda mais digno de atenção, e é por seu porte e firmeza nessas épocas assinaladas que se deduzem os indícios mais verdadeiros do progresso do espírito público. Paris forneceu uma prova irrefutável desta verdade em 15 de abril de 1792 quando, ameaçados pela corte e por seus numerosos partidários, separados da guarda nacional, que se teve o pérfido artifício de se indispor contra eles, abandonados enfim por seus corpos administrativos, e pela assembleia legislativa, seus habitantes perseveraram no projeto de dar uma festa verdadeiramente popular aos quarenta suíços, resto infortunado desse regimento de Chateauvieux, mártir de seu amor pela revolução.

Não entraremos nos detalhes materiais da festa que, deste ponto de vista, não podia deixar de se parecer a muitas outras que a

${ }^{9}$ RESTIF DE LA BRETONNE, N.E., Les nuits révolutionnaires (F. FunckBrentano ed.), Paris, 1910? p.79.

${ }^{10}$ Collection Complète des Tableaux historiques de la Révolution Française, Paris, 1804, quadro 59, p. 239. 
precederam ou seguiram; mas de fato mereceu o nome de festa da liberdade: via-se o busto de Sidney entre os grandes homens que sempre honram esses espetáculos; e dois sarcófagos, monumentos lúgubres da ferocidade de Bouillé e de La Fayette, acusavam-nos com coragem diante dos olhos de Paris inteira. As quarenta vítimas (uma morrera nas galés e outra adoecera) precediam o carro da liberdade, o mesmo que transportara Voltaire. A filosofia nos dera a liberdade, seu triunfo devia pertencer às mesmas épocas e embelezarse com os mesmos ornamentos. Nesse dia, iluminado pelo mais belo dos sóis, o Champ de Mars foi purificado e o patíbulo dos patriotas se transmutou em altar da pátria.

Em seu ensaio sobre as festas nacionais, Boissy d'Anglas parte da naturalidade no comportamento humano mais ou menos evocada por Rousseau, da importância de uma opinião pública sobre os valores sociais e da existência e desenvolvimento de "costumes nacionais". Ao mesmo tempo, parece possuir uma espécie de concepção psicanalítica para garantir o sucesso das festas nacionais, concepção que pode ser considerada fruto da naturalidade mais espontânea ${ }^{11}$ :

Rousseau, que fez nos hábitos morais e privados a revolução que deveis operar nos hábitos políticos e nacionais, para fazer com que seus preceitos e leis sejam amados, revestiu-os com tudo que pode impressionar a alma e emocionar o coração; foi assim que persuadiu as mulheres a cumprirem os deveres da natureza... O mesmo procedimento deve ser adotado para tratar os povos; já que os povos, como as mulheres, só estão dispostos a ceder diante daquilo que os emociona ou compraz.

É pela emoção e com o prazer que se pode dirigir eficazmente um povo, e ambos os meios estão em vossas mãos...

As Festas Nacionais se sustentam por toda a força que o costume exerce; falam à alma por meio das recordações, e ao coração por meio do sentimento de emoções já passadas; conferem beleza a estranhas sensações, e também às mais próximas, e se associam a todo o encanto das impressões da infância, apesar de longínquas. Os prazeres da infância e da juventude, os primeiros pensamentos da alma, refletem-se por toda a vida nas cerimônias públicas e nas festas

11 BOISSY D’ANGLAS, Essai sur les fêtes nationales adressé à la Convention Nationale, Paris, pp. 6, 12, 17 e 19. que a elas foram mescladas; assim, o coração desfruta do passado e do presente ao mesmo tempo. Assim, os exemplos que oferecem e os preceitos que consagram se reproduzem rodeados dessas doces e fortes impressões, obtendo uma enorme influência.

Assim, as festas nacionais terão por adorno as sensações mais felizes da alma; assim, ao lembrar aos homens as primeiras emoções da infância, quer dizer, as que são mais puras, as que a inocência acompanhava, junto com a ingenuidade, a confiança e a boa-fé, ajudarão a adoçar e a aperfeiçoar os costumes dos povos e a dar às nações essa sensibilidade moral que deve existir entre elas e que deve ser demonstrada, tanto em suas ações coletivas, como nas de seus particulares.

É esse prestígio das antigas recordações, é esse poder das antigas impressões, é esse terno respeito que sentimos pelas coisas que existiram muito antes de nós e cujo relato suscitou nossas primeiras atenções e dominou nossas primeiras ideias, coisas que transformaram todas as instituições antigas em instituições divinas e fizeram os homens acreditarem que ninguém senão o Ser Supremo podia ter ordenado práticas cuja memória inspirava tão poderosa emoção, e que era possível reproduzir com tanta doçura em diversos instantes da vida.

De fato, há algo de sobrenatural no modo como nossas faculdades são modificadas por nossas primeiras sensações: o que fascinou na infância nos parece uma emanação do próprio céu...

Boissy d'Anglas reúne essa apresentação das festas nacionais, segundo um critério que bem poderia ser chamado de psicologia social, às ideia de Robespierre em seu discurso sobre a relação entre as ideias morais e religiosas e os princípios republicanos. François Antoine Boissy, falando "do Ser Supremo ao povo mais iluminado do mundo", compara Robespierre com "Orfeu ensinando aos homens os primeiros princípios da civilização e da moral".

Os princípios de Boissy coincidem com a inspiração geral de umas festas nacionais, patrióticas e adornadas com a arte da antiguidade clássica, 
conforme a concepção da época. A devoção ao Ser Supremo une-se a essas considerações como algo natural. Entretanto, adverte ${ }^{12}$ :

Reconhecendo a existência do Ser Supremo, tereis de assumir também o compromisso para com vossos povos de impedir que esta ideia sublime possa ser transformada, nas mãos de alguns maldosos hipócritas, num meio de opressão e tirania.

Já sabeis que o abuso está próximo do mais justo e do mais sábio, e tenta corromper sua primitiva simplicidade. E que verdade sofreu mais abusos que a verdade do Ser Supremo? Por toda a parte a ideia consoladora de Deus foi desnaturada com extrema complacência... chegando os homens a se servirem de seu culto como instrumento de seus crimes.

É na morte que a nova sociedade e o novo homem, oriundos da revolução e da república, devem mostrar-se especialmente distintos entre si, recusando os velhos rituais e os pomposos e inúteis espetáculos ${ }^{13}$ :

A morte é o sono do justo e o refúgio do oprimido. Acostumemo-nos de uma vez a considerá-la uma bênção da Providência, e não uma lei bárbara da natureza..

A história registra o relato de uma destas festas que, vinculando-se a uma das maiores ações, a maior glória da antiguidade, produziu uma emoção viva e profunda em todas as almas. Refiro-me aos jogos fúnebres que precederam, na Lacedemônia, o feito das Termópilas; desta pompa santa e augusta, onde se viu trezentos espartanos, que sob a liderança de Leônidas iam morrer pela liberdade, celebrarem eles mesmos, na presença de seus pais, de seus amigos, de seus concidadãos, os funerais que os esperavam.

Nunca um espetáculo de tamanha proporção penetrou na alma humana: nunca a muda eloquência dos grandes acontecimentos atingiu grau mais sublime; e se considerarmos que, independentemente do poderoso motivo que unia todos esses cidadãos - a salvação da pátria, que sem dúvida implicava a morte -, notamos que ainda nutriam esperanças mesmo em meio a perigos de tal imponência, e percebemos que esta esperança era fortalecida pelo aspecto extraordinário da cerimônia que organizaram. Se pensarmos

\footnotetext{
${ }^{12}$ Idem, op. cit., p. 22.
}

${ }^{13}$ Idem, pp. 65, 90, 93, 95 . que, no mesmo instante, a Grécia estava sendo assediada por um milhão de soldados, e que trezentos homens iriam combatê-los; se recordarmos que a vitória era então uma quimera e a mais desastrosa das derrotas, inevitável, advertiremos, contudo, que o êxito era o destino de todo um povo; a situação assim entendida gerava emoções inauditas, o próprio perigo adquiria uma grandeza que convidava solenemente à magnânima entrega dos trezentos republicanos...

O desprezo da morte é, com efeito, a primeira virtude dos republicanos; a liberdade não está bem implantada num povo onde os tiranos podem obter reféns...

A necessidade de uma festa nacional com participação mais ativa do povo será formulada precisamente por um dos adversários de Robespierre que mais personificava os vícios que o Incorruptível atacava, Merlin de Thionville. Com a queda do presidente da Convenção depois de 9 do termidor, Merlin investia contra a festa robespierriana por ser esta mais um espetáculo do que propriamente uma festa. Aludia à festa da Confederação realizada no Champ de Mars como sendo esta uma festa verdadeiramente popular.

Entretanto, o que Merlin propõe para festejar a evacuação militar da República é uma espécie de tragédia em três atos com 23 cenas, nas quais a participação popular se restringe a um papel estritamente determinado.

O projeto de Merlin confunde a caricatura da festa revolucionária, que dita ao povo tudo o que este deve fazer em cada momento, sendo a participação popular uma espécie de afetação, o que leva a crer que só pode ter sido forçada. ${ }^{14}$

Diante desse tipo de ponto de vista, destaca-se o calor e a ponderação de Bernardin de Saint-Pierre ${ }^{15}$ ao antecipar-se às manifestações que se concentrarão nos boulevards da Paris contemporânea:

As festas são, na navegação que é a vida, o mesmo que as ilhas no meio do mar, locais de refrigério e de repouso. Inclusive as festas mais misteriosas têm tal poder sobre os povos que com suas músicas e suas procissões, como ocorre com o catolicismo, atraem

\footnotetext{
${ }^{14}$ Moniteur Universel, ${ }^{\circ}$ 93, 1794.

${ }^{15}$ SAINT-PIERRE, Bernardin de, Voeux d'un Solitaire (1789), em Oeuvres, Paris, 1840, t. I, p. 744.
} 
enormemente os povos selvagens e mantêm na religião os civilizados. O que aconteceria se à sua expressão física fosse acrescentada outra moral? É nesse sentido que as prefeituras devem criar eventos patrióticos, para unir mais os seus cidadãos em torno da constituição. Já se fez uma sublime tentativa no Champ de Mars, então chamado de Champ de la Confédération. Contudo, era uma festa militar, quase todos os homens estavam fardados. É preciso rodear o altar da pátria com uma pompa civil e religiosa e mesclar aos guardas nacionais coros de moças e crianças com coroas de flores, cantando ao som das flautas e dos oboés, alternadamente, hinos franceses parecidos ao poema secular de Horácio. Essas festas públicas devem ser presididas por seus pontífices naturais e pelos chefes da administração, com o rei à frente: assim se recuperará a origem do sacerdócio.

Com esse fim, o Champ de la Confédération pode constituir-se num local mais digno, rodeando-o, como um circo romano, de bancos de pedra e de estátuas de nossos homens ilustres e alojando a assembleia nacional na Escola Militar, que o limita numa de suas extremidades. No entanto, por mais amplo que possa ser esse espaço, ainda me parece pequeno para dar festas para o povo de Paris.

Proponho um espaço ainda maior, mais conveniente... Para reunir comodamente o povo de Paris, não se deve afastá-lo da cidade; e como nenhuma praça pode contê-lo, em lugar de atraí-lo dos bairros a um centro comum, é melhor, ao contrário, levá-lo do centro aos bairros. Assim, em lugar de atraí-lo, como se fazia no antigo regime, a essa miserável praça da Greve (assim chamada por causa da praia - greve que o rio formava na frente da prefeitura), destinada às execuções que desonram a Prefeitura há tanto tempo, é preciso atraílo às alamedas (boulevards) circulares. Ali encontrará uma longa alameda de várias léguas de comprimento, com a sombra de quatro fileiras de árvores, sem contar as que estão plantadas do lado de fora dos muros. Cada alameda está ao alcance dos moradores de cada bairro, e cada habitante pode percorrer a pé, a cavalo ou de carroça esse vasto espaço circular que circunda Paris, desfrutando ao mesmo tempo da cidade e do campo, uma vez que os muros que interceptam a vista serão derrubados. Essa localização acarreta também outras vantagens consideráveis: pode-se utilizar as esplêndidas edificações das barreiras, construídas em forma de rotundas, de colunas colossais, de panteões, de templos egípcios, anteriormente destinados a abrigar os comissários do fisco, para que sirvam de monumentos dedicados aos grandes homens que fizeram a pátria brilhar. Suas estátuas poderiam ser colocadas entre as colunas ou sobre os tablados desses edifícios, nas portas em que desembocam as estradas das províncias de que são oriundos esses grandes homens. Suas augustas imagens estariam de frente para essas mesmas províncias, como se convidassem seus habitantes ao acesso à capital, ou fizessem os da capital se interessarem pelos da província. Cada um desses monumentos poderia servir de hospedagem passageira para os pobres viajantes. Ali figuraria, em grandes tábuas de pedra, uma série de inscrições relativas aos grandes homens que mereceram ser considerados como divindades tutelares pelos serviços prestados aos infortunados. Nos dias das festas patrióticas seriam enfeitados com guirlandas de flores e folhagens. Ali seriam distribuídos víveres ao povo. E nas noites dos festejos poderiam ser adornados com cordões de luzes. Esses templos da hospitalidade, de antiga arquitetura unidos uns aos outros por uma tríplice avenida de verdes árvores, cheios de um povo livre e feliz, formariam ao redor de Paris uma coroa de felicidade e de glória que a transformaria na capital das nações.

A assembleia constituinte decretou que a nova Igreja de Sainte Genevieve serviria para abrigar as tumbas dos grandes homens que se fizeram credores da nação. Como esses ilustres cidadãos pertencem a diferentes confissões que se excomungam mutuamente, parece oportuno, para que concordem ao menos depois da morte, não admitir nenhum culto no templo que acolheria suas cinzas. Sobre este tema foi publicada uma interessante Memória, na qual se propõe a dedicação ao altar da pátria onde os magistrados pronunciariam seus juramentos. Mas onde se encontram as virtudes que só podem repousar no Ser Supremo, o único que as distribui e o único que as recompensa dignamente?

Gostaria, pois, que esse monumento fosse consagrado à Divindade com estas palavras: A Deus, pai de todos os homens. A Memória que citei observava que a escultura deveria representar, nas extremidades de suas naves, quatro religiões: a judaica, a grega, a romana e a galicana. Não sei que reflexões terão levado a pensar nisto, considerando que são quatro religiões que conviveram com o ódio e a perseguição. Parece-me mais conveniente introduzir no novo templo a religião primitiva ou patriarcal, da qual emanam todas as demais, e nomear os primeiros magistrados pontífices da mesma. Seu antigo culto, estendido com simplicidade por toda a terra, conviria aos 
grandes homens de todas as confissões, pois se são grandes é por terem servido a todo o gênero humano sem exclusões. Este culto é o único que pode reunir os homens de todas as religiões, já que nenhuma delas nega que Deus seja o princípio e o fim. Assim, os mortos dariam aos vivos lições de tolerância.

Essa opinião de Bernardin de Saint-Pierre sobre as festas populares é coerente com sua adesão à teofilantropia, que ele mesmo divulgou e pregou durante a Revolução, e com a tendência observada em alguns artífices dessas festas a irmanar os projetos urbanísticos, as comemorações patrióticas, a religiosidade pública, a filantropia paternalista e o esplendor da França no mundo e de Paris na França. A relação entre uma nova concepção urbanística e a democracia republicana também está presente em outros escritos, como este de A. Auger que citamos ${ }^{16}$ :

... Se em lugar desses suntuosos e inúteis fossos, desses grandes edifícios que o povo só pode contemplar de fora, tivesse sido construído um peristilo amplo e magnífico com plataformas, deixando ao ar livre, com luz, o lado que dá para o Sena, prolongando essa disposição até Neuilly, o que teria acontecido? O povo teria um refúgio em caso de chuva em seus passeios pelas Tulherias e pelos Campos Elíseos. E quando o bom tempo lhe permitisse passear pelas plataformas, bem como sob as arcadas, como essa construção seria embelezada por uma multidão sempre em movimento! De longe pareceria uma construção viva e animada. Se eu não tivesse nascido nesta capital, a primeira vez que tivesse chegado a Paris, depois de uma caminhada pela cidade, teria dito: Aqui o rei e os grandes homens são tudo e a plebe não é nada. Nessa urbe tão bem decorada, vejo mansões e grandes praças rodeadas de mansões; mas, onde existem refúgios e abrigos para o povo, salvo os hospitais e os cárceres? Que sejam construídos edifícios magníficos para o povo, as pessoas se orgulharão dessas magnificências e as verão como suas, pagas com seu dinheiro..

Por outro lado, o próprio Auger defende uma volta aos conceitos clássicos da tragédia para reforçar o culto pátrio ${ }^{17}$ :

${ }_{17}^{16}$ AUGER, A., Moyens d'assurer la Révolution..., Paris (1789-90), p. 20.

${ }_{17} \ldots$ De la Tragédie Grecque et du nom qu'on devroit lui donner dans notre langue, pour s'en faire une juste idée, Paris, 1792, p. 46.
Eu gostaria que pudéssemos prescindir de espetáculos; que nos bastasse o espetáculo da natureza, ao mesmo tempo tão uniforme e variado, da simplicidade majestosa do culto de nossos altares, de algumas festas patrióticas cujo retomo nos recordaria a conquista da liberdade que tanto suor e tantas penas nos custou... mas se não pudermos prescindir de novos espetáculos, proponho aos nossos poetas, cujos sentimentos e ideias estejam exaltados e fortalecidos por uma liberdade nova, por uma ordem de coisas verdadeiramente digna para o homem que sabe merecê-la, proponho-lhes não esse novo gênero de drama cujas regras a natureza inspirou ao mais livre e engenhoso dos povos, mas a ópera-trágica, que tentei mostrar nesta curta dissertação segundo o modelo que Ésquilo, Sófocles e Eurípedes nos deixaram, tragédias de tom ainda mais forte e antigo, de caráter mais pronunciado e nacional, onde as grandes paixões se utilizem de uma linguagem ainda mais verdadeira e nacional, tragédias ainda mais propícias ao interesse dos cidadãos e encanto dos estrangeiros, seja pela grandeza e força dos pensamentos e dos sentimentos, seja pela beleza dos versos e a perfeição da poesia.

Neste sentido, Auger elogia Mérope de Voltaire.

A festa dedicada a Le Peletier talvez tenha sido a que foi projetada com maior conjugação de recursos do culto republicano. Michel Le Peletier de Saint-Fargeau, ex-marquês, votara a favor da morte de Luís XVI. Na véspera da execução do rei, é assassinado por um monarquista. A Convenção vota imediatamente a panteonização. Le Peletier distinguira-se pela elaboração de um plano de organização da instrução pública.

A cerimônia contou com a participação de destacamentos militares e civis, representações de cidadãos, com a estátua da Liberdade, a Declaração dos Direitos Humanos e o cadáver de Le Peletier artisticamente disposto. M.-J. Chénier determinou assim a ordem da procissão republicana para os funerais ${ }^{18}$ :

$1^{\text {o }}$ Um destacamento de cavalaria, precedido de trombetas com surdina; $2^{\circ}$ Sapadores; $3^{\circ}$ Artilheiros sem os seus canhões; $4^{\circ}$ Destacamento de tambores cobertos; $5^{\circ}$ A Declaração dos Direitos Humanos levada por cidadãos; $6^{\circ}$ Voluntários das seis legiões e 24 bandeiras; $7^{\circ}$ Destacamento de tambores; $8^{\circ} \mathrm{Um}$ estandarte

\footnotetext{
${ }^{18}$ Révolutions de Paris, $\mathrm{n}^{\mathrm{o}}$ 185, p. 226.
} 
ostentando os dizeres do decreto da Convenção que ordena o traslado do corpo de Le Peletier para o Panteão; $9^{\circ}$ Alunos da pátria; $10^{\circ} \mathrm{Os}$ comissários de polícia, da junta de conciliação, os juízes de paz, os presidentes e comissários das seções, o tribunal de comércio, o tribunal penal provisório, os seis tribunais do departamento, o corpo eleitoral, o tribunal penal do departamento, a prefeitura de Paris, os distritos de Saint-Denis e do Bourg de l'Égalité, o departamento, o tribunal de cassação; $11^{\circ} \mathrm{O}$ Busto da Liberdade conduzido por vários cidadãos; $12^{\circ}$ Destacamento de tambores; $13^{\circ}$ O fascio dos 84 departamentos levado por federados; $14^{\circ} \mathrm{O}$ conselho executivo provisório; $15^{\circ}$ Destacamento da guarda da Convenção Nacional, com seus deputados desfilando em colunas de dois...; $18^{\circ} \mathrm{Em}$ meio aos deputados, um estandarte com as últimas palavras de Le Peletier; $19^{\circ} \mathrm{O}$ corpo transportado por vários cidadãos, exposto da mesma maneira que na praça de Piques; $20^{\circ}$ Em volta do corpo, artilheiros com o sabre desembainhado na mão, acompanhados pelo mesmo número de veteranos; $21^{\circ}$ Banda de música da guarda nacional executando a marcha fúnebre durante o percurso; $22^{\circ}$ Familiares do morto; $23^{\circ}$ Grupo de mães com seus filhos; $24^{\circ}$ Destacamento da guarda da Convenção; $25^{\circ}$ Tambores cobertos; $26^{\circ}$ Voluntários das seis legiões e 24 bandeiras; $27^{\circ}$ Tambores cobertos; $28^{\circ}$ Federados armados; $29^{\circ}$ Sociedades civis; $30^{\circ}$ Cavalaria e trombetas com surdinas, depois o destacamento de cavalaria fechando o cortejo.

Os Tableaux ${ }^{19}$ descrevem o desfile com os tons mais característicos do culto patriótico:

No dia 24, antes do meio-dia, o corpo do mártir da liberdade saiu da casa de seu irmão, deitado e semicoberto em seu leito de morte. $\mathrm{O}$ pedestal da estátua de Luis XIV, na praça Vendôme, estava preparado para recebê-lo. A visão desse quadro comovedor dilacerava a alma de todos os cidadãos que lotavam a praça. As vestes perfuradas e ensanguentadas da vítima; o sabre ainda manchado com seu sangue; esse corpo estendido e deixando ver a mortal ferida que recebera; a cabeça inclinada do desditoso Le Peletier, pálida mas não desfigurada, parecendo mergulhada num sono plácido; as últimas palavras do morto transcritas no pedestal; seu irmão, triste e vacilante, atrás dele; uma multidão de artilheiros disputando a honra de partilhar a gloriosa carga; à frente, um coro

\footnotetext{
${ }^{19}$ Idem, op. cit., 1. 15, p. 226, e 1. 6, p. 310 (BHVP).
}

musical executando trecho após trecho seus acordes dolorosos, interrompidos pelo rufar dos tambores cobertos de negras roupagens, rufar surdo e profundo; a estátua da lei estendendo seu braço de modo a atingir o assassino ${ }^{20}$ somai a tudo isso um céu cheio de nuvens, as tochas funerárias, os ciprestes, um silêncio religioso e, sobretudo, as lembranças do dia 21 (a execução de Luís Capeto): tudo concorria para imprimir na alma as mais fortes emoções; tudo demonstrava o poder dos grandes espetáculos sobre o povo, quando animados por ideias morais que comovem o coração ao mesmo tempo em que o cerimonial excita a vista. $\mathrm{O}$ presidente da Convenção aproximou-se do morto e colocou-lhe na cabeça uma coroa de azinheira salpicada de flores. Esse gesto de beleza, esse grande ato de reconhecimento expresso com simplicidade e emoção, gerou uma vivíssima sensação.

Durante a marcha foram feitas várias paradas, particularmente diante dos clubes dos Jacobinos e dos Cordeliers. Era singular que, numa cerimônia onde evitava-se cuidadosamente toda aparência religiosa, fossem prestadas homenagens a associações que haviam conservado nomes monásticos. Em todo caso, as sociedades populares, que haviam sido o principal motor da revolução, exerciam então uma influência que as situava no centro da opinião pública e, por isso mesmo, as tomava muitas vezes perigosas para o órgão legislativo: não é possível impedir sua associação ao triunfo daquele que tinha protegido (Robespierre). O cortejo parou diante do Clube dos Cordeliers, cuja fachada achava-se coberta de guirlandas de ciprestes: ali foi pronunciada uma arenga e cantado um hino. O acompanhamento da cerimônia ficou a cargo do povo, que a realizou com perfeição. Por ambos os lados, as lanças erguiam-se e com as pontas juntas formavam uma balaustrada, atrás da qual a multidão organizava-se com naturalidade, deixando o centro da rua inteiramente desimpedido.

Ao chegar ao Panteão, o corpo de Le Peletier foi colocado num estrado. A orquestra, situada nas galerias superiores, tocou uma peça de grande efeito expressivo. Os dois irmãos da ilustre vítima estavam de pé e com a cabeça descoberta, ao lado do estrado. O primogênito pronunciou um discurso no qual recordou as obras do irmão, o plano

${ }^{20}$ Segundo a programação apresentada por Chénier, devia tratar-se da estátua da Liberdade. 202 
de instrução pública que deixara, e ofereceu-se para entregar a própria vida, também como o irmão, na defesa dos direitos do povo.

Um membro da Convenção (Barère), depois de elogiar o colega, convidou a todos para que jurassem sobre seu corpo o compromisso comum de salvar a pátria, esquecendo quaisquer animosidades pessoais. $\mathrm{O}$ auditório todo ergueu a mão num gesto de consentimento. Quantos males teriam sido evitados à França se esse juramento tivesse sido respeitado!

O que talvez tenha causado maior impacto foi o fato de um voluntário se lançar ao estrado, tomar o sabre que ferira Le Peletier e, brandindo-o no ar, jurar vingar o crime. Que, de fato, não tardou em ser castigado... ${ }^{21}$

A visão crítica da festa patriótica é exposta pelos redatores de Révolutions de Paris numa conjuntura especialmente crispada: depois do ataque e massacre das Tulherias ou de São Lourenço, começando da guerra, prendendo o rei, impondo sua autoridade e a dos jacobinos à Comuna de Paris e preparando o desenlace com os massacres de setembro ${ }^{22}$ :

Era sexta-feira, 25 de agosto e festa de Luís IX, quer dizer, quinze dias depois do massacre de Saint-Laurent, ordenado por Luís XVI, e devia ser realizada a solenidade nacional em memória dos patriotas mortos no palácio das Tulherias. Mas a mesquinhez do obelisco encarregado a Palloi (Palloy) ${ }^{23}$ forçou sua substituição por um monumento mais digno. Poyet, o arquiteto da cidade, conseguiu algo muito melhor, copiando a antiguidade com simplicidade e bom espírito. Pena que M. Poyet seja o mesmo que se vendeu aos caprichos de Breteuil e às calamidades da corte, dirigindo as obras que ordenou na Bastilha para deixá-la em condições de canhonear os cidadãos em 14 de julho de 1789.

A construção da pirâmide de estilo egípcio obrigou a adiar a festa fúnebre até o domingo 27. O patriota Sergent, administrador da Comuna e artista, foi o organizador da festa, dando mostras de gosto e inteligência. A ele se devem as quatro inscrições em prosa da pirâmide, e valem muito mais que os quartetos do poeta Chénier, que

${ }^{21}$ Pâris, autor do assassinato, suicidou-se ao ser descoberto.

22 Révolutions de Paris, $\mathrm{n}^{\circ} 164$, agosto-setembro de 1792.

${ }^{23}$ Pierre F. Palloy quis também protagonizar a demolição da Bastilha e montou uma loja de venda de "souvenirs" da antiga fortaleza. foi apelidado de Graco, mas que agora é chamado de Chénier, o capelão, depois de sua admissão no clube da baixa Sainte-Chapelle e de sua adesão formal aos princípios dos feuillants, ${ }^{24}$ reunidos nesse antro semi-aristocrático no qual figurava Roucher; que se julgue pelo resto os frequentadores. Uma das inscrições em prosa era comovedora por seu laconismo: "Silêncio, repousam".

O público nem sempre esteve à altura das circunstâncias. A localização escolhida dava a essa festa um caráter sombrio, apropriado para o recolhimento. A pirâmide cobria o grande espelho d'água das Tulherias, de frente para o palácio de cujas janelas a morte se lançara sobre os patriotas em 10 de agosto, enchendo todo o espaço circundante de cadáveres, enquanto do outro lado, acima do Carroussel, o primeiro teatro do massacre, o sangue dos traidores já era vertido sob a guilhotina e nesse jardim era edificado um monumento à g1ória dos patriotas da jornada do dia 10 . Na véspera da festa do rei-assassino, um de seus cúmplices foi decapitado; no dia seguinte à festa foram prestadas as últimas homenagens aos cidadãos massacrados. Assim, no mesmo lugar e na mesma semana, Paris cumpria todos os seus deveres ao mesmo tempo; distribuía o castigo e o elogio e satisfazia simultaneamente a justiça e o reconhecimento.

O cortejo deixou a casa comunal entre as cinco e as seis... Um cavaleiro, em meio a sua tropa, abria o desfile, levando um estandarte em que se lia: Aos manes dos cidadãos franceses/ Mortos em defesa da liberdade,/A pátria agradecida..

Entre nuvens de incensos queimados ao seu redor, o sarcófago dos cidadãos mortos na matança de São Lourenço era transportado com lentidão por bois, à maneira antiga, proporcionando aos espectadores o tempo necessário para que oferecessem um tributo de lágrimas à memória de seus irmãos perfidamente imolados no dia 10. Mas esse natural sentimento de tristeza e de lamentação logo cedia lugar a outro mais conveniente hoje em dia, ao contemplar um grupo de federados com seus sabres desembainhados e entrelaçados com ramos de carvalho.

Um estandarte exprimia suas intenções em duas linhas que ecoaram no coração e nas bocas de todos ao longo do desfile: "Chorai esposas,

24 Os feuillants, dissidência dos jacobinos, ao que parece desejavam frear a Revolução em sua primeira constituição de cunho ainda monárquico. André Chénier e Roucher morreram na guilhotina dois dias antes de Robespierre, por sua adesão ao feuillantisme. 
mães e irmãs/ A perda das vítimas imoladas pelos traidores;/ Nós juramos vingá-las". Outro estandarte, sem contradizer o anterior, usava outra linguagem, mais adequada aos objetivos que anunciava: "Se os tiranos têm seus assassinos, / O povo tem suas leis vingadoras". E depois vinha a estátua da lei, armada com sua espada, seguida pelos juízes de todos os tribunais.

A seguir vinha a prefeitura precedendo a Liberdade, transportada por uma multidão de guardas nacionais, orgulhosos de sua carga. Depois vinha a Comissão administrativa provisória que substitui o departamento e, finalmente, a assembleia nacional, cujo presidente levava nas mãos várias coroas cívicas que seriam depositadas ao pé do monumento piramidal das Tulherias. Quando o cortejo chegou pela ponte giratória, iluminaram-se os quatro altares que acompanhavam a tumba, cujas altura e volume de grandes proporções encobriam o odioso palácio. Ainda não havia anoitecido quando o início do cortejo penetrou no jardim; e, às nove horas, mal havia acabado de chegar à beira do espelho d'água, teatro da festa, porque muitos cidadãos, homens e mulheres, quiseram participar da mesma, cada um na posição atribuída a sua seção. ${ }^{25}$ Havia um número considerável de sans-culottes munidos com seus piques; ${ }^{26}$ mas eram logo ultrapassados por uma multidão que trajava fardas de todos os batalhões, que se dirigiam apressados para a festa, na intenção de, por algum modo, compensar sua ausência no próprio dia da ação.

Ao chegar, dava-se a volta ao redor da tumba piramidal de granito, os estandartes eram ali colocados e depositadas as coroas ao som da marcha fúnebre, composição grave e severa de Gossec, cujo talento musical é mais sólido do que os princípios que externou ao fazer parte do clube da baixa Sainte-Chapelle e firmar a petição Guillaume.

Assim portanto o arquiteto, o músico, o orador e o poeta escolhidos para esta solenidade nacional eram acusados de falta de civismo. Fato bastante singular.

Uma tribuna para arengas, parecida à da tragédia de Graco encenada no teatro da rua de Richelieu, estava situada entre o anfiteatro ocupado por deputados, administradores, juízes e magistrados e a

\footnotetext{
${ }^{25}$ Paris tinha 48 seções desde maio de 1790
}

${ }^{26}$ Robespierre dissera, referindo-se ao pique: "Esta arma é de certo modo sagrada". orquestra, composta por grande número de virtuoses mais patriotas do que seu maestro. Depois da marcha fúnebre, Chénier subiu à tribuna e pronunciou um discurso que foi muito aplaudido e cuja publicação foi solicitada pelo próprio povo. A música tomou a soar, rematando a festa com peças cheias de brilho e vivacidade, apoteose das ilustres vítimas cuja memória estava sendo celebrada. Às dez estava tudo terminado; e a cerimônia, da qual participou quase toda Paris, não foi ofuscada por incidente algum. Assim acontece há quatro anos, quer dizer, desde que o povo se encarrega de sua própria proteção.

Que nos seja permitido fazer uma observação. Essa cerimônia lúgubre, cujo conteúdo devia inspirar consecutivamente o recolhimento da tristeza e a santa indignação contra os autores da matança que recordamos, não surtiu os efeitos desejados na massa da população. No cortejo, via-se a tarja de crepe em todos os braços, mas o luto não se mostrava em todos os rostos. Um ambiente de dissipação, e inclusive uma ruidosa alegria, contrastavam excessivamente com os símbolos da dor, destruindo sua intenção.

No dia seguinte, M. Sergent, ao invés de mandar retirar as figuras da Liberdade e da Lei, teve, ao contrário, o cuidado de colocá-las atrás da pirâmide, no intuito de que o povo pudesse contemplá-las com facilidade, sendo as duas únicas divindades dignas do culto de uma nação ilustrada. Na manhã da terça-feira, essas duas formosas figuras estavam despojadas de suas roupagens, e maliciosamente expostas a todos os olhares com a nudez mais odiosa e menos decente. Este delito deve ser castigado. Ele sem dúvida foi propiciado por alguns padres enciumados do incenso que no dia anterior ardeu em outros altares que não os seus.

$\mathrm{O}$ culto republicano, apesar da prioridade que dedicava à representação e à devoção das ideias de liberdade e pátria, foi confundido com a iniciativa ateia e teofilantrópica, menos enfática em relação ao patriotismo ad hoc e mais preocupada em estabelecer uma ideologia filosófica em torno da ideia da razão tal como fora gerada no Iluminismo. Essa confusão também ficou patente nos ataques contra os cultos republicanos da Revolução. 
Contrastando com o respeito e a emoção que utiliza na descrição da apoteose de Rousseau no outono de 1794, Mercier ataca assim os cultos republicanos ${ }^{27}$ :

Toda Paris contemplou sem dizer uma palavra essas procissões da liga jacobina. Embriagados de sangue e vinho, regressando do espetáculo dos patíbulos, os sacerdotes e sacerdotisas da Razão acompanhavam com andar vacilante o carro de sua impura divindade. Outro carro o seguia: era uma orquestra ambulante de músicos cegos, imagem fidelíssima da razão à época... Essas pantomimas, já por si inacreditáveis, foram seguidas pelas do espantoso Marat... templos... mausoléus... arcos de triunfo... Quem teria imaginado que, depois dos acontecimentos de 9 do termidor, esse novo Moloch receberia as honras do Panteão? Mas esse dia foi, antes, o de seu juízo final, e não o de seu triunfo. Dir-se-la que se evitava respirar o ar por onde passava sua carniça.

Chateaubriand caricaturou assim o sabor de antiguidade dos cultos revolucionários ${ }^{28}$ :

... era o momento em que o organismo político, cheio de manchas de corrupção, caía em meio a uma dissolução geral, quando uma raça de homens, levantando-se de repente, invocou ousadamente o tempo de Esparta e de Atenas. Ao mesmo tempo se faz ouvir o grito de liberdade; o velho Júpiter, despertando de um sono de mil e quinhentos anos, coberto pelo pó do Olimpo, fica assombrado ao encontrar-se em Sainte-Genevieve. Coloca-se na cabeça do bobo de Paris o boné do cidadão da Lacônia; e, em todo o seu vício e corrupção, o pequeno valentão francês se arroga as grandes virtudes de Lacedemônia; e é forçado a representar Pantalão ante os olhos da Europa, nessa pantomima de Arlequim.

${ }^{27}$ MERCIER, L.S., Le Nouveau Paris, Paris, 1798, capítulo "Festas da Razão".

${ }^{28}$ CHATEAUBRIAND, F.R., Essai historique, politique et moral sur les Révolutions anciennes et modernes, Bruxelas, 1824 ( $1^{\mathrm{a}}$ ed. 1797), p. 366. Renouvier (Histoire de l'Art pendant la Révolution, Paris, 1863, p. 431) cita a opinião de um médico estrangeiro segundo a qual "a maior parte dessas festas assemelha-se um espetáculo de ópera e, desse ponto de vista, algumas possuem efeito pitoresco, agradável à vista mas sem chegar a impressionar a alma do espectador".
O culto republicano desapareceu com as apoteoses de Bonaparte e com o novo congraçamento com a Igreja Católica. Vejamos duas pequenas amostras deste novo estado de coisas.

Nos dias 9 e 10 do termidor do sexto ano (27 e 28 de julho de 1798), as obras-de-arte arrebatadas aos italianos chegaram triunfalmente a Paris. Em 24 de julho, Bonaparte já entrara no Cairo ${ }^{29}$ :

Era sem dúvida em Paris, nesta nova Atenas, que deviam inelutavelmente ficar essas imortais obras-primas que Roma arrebatara à antiga Grécia. Que cesse a jactância dos Jogos Olímpicos e das outras festas nacionais dos antigos povos da Hélade e da Lacônia; que não sejam mais oferecidas a nossa admiração as pompas triunfais do Capitólio: as de 9 e 10 do termidor eclipsam tudo que já se viu nesse gênero. Que troféu tão esplêndido, que espetáculo tão imponente e majestoso o da entrada e recepção em Paris das inimitáveis estátuas de Apolo, Laocoonte, Hércules, dos quadros de Rafael, de Corregio...

A Igreja Católica faria sua reaparição em termos de uma sábia decisão de legisladores e homens de estado, antes mesmo de suas novas concordatas com o Império e os regimes posteriores ${ }^{30}$ :

A Constituição dos Estados Unidos da América não tolera que em solo americano haja homens que professem publicamente o ateísmo.

A ideia de um deus supõe uma religião, e uma religião supõe a necessidade de um culto; existiu em todos os povos, e às vezes vinculouse com sucesso às instituições sociais. Se a religião natural podia convir a um pequeno número de filósofos, jamais conviria às pessoas comuns. O deísmo puro não é alimento suficiente para o coração humano em geral: faltam-lhe relações mais sensíveis com o objeto de suas adorações, necessita de uma religião prática, de ritos, cerimônias, altares e locais de encontro: tudo isto é a essência das religiões, e sem isto não podem subsistir. O legislador deve tolerar e proteger todos os cultos que não se oponham à Constituição; e, sob esse aspecto, deve segurança e proteção ao ministro do culto católico, já que a essência desta religião, quando adequadamente entendida, é a conveniência de todos os governos.

${ }^{29}$ Tableaux, op. cit., quadro 136.

${ }^{30}$ DUBRUEL, P.LJ., Rapport au Corps législatif, Conseil des cinq-cents, Paris, 1797, pp.9 e 11. 


\section{Nota sobre a Revolução Americana de Independência}

A revolução que culminou com a independência dos Estados Unidos não implantou uma renovação religiosa no estilo da Revolução Francesa. Não desenvolveu o deísmo filosófico ou patriótico, o ateísmo republicano nem o cristianismo evangélico comprometido com a revolução social. $\mathrm{O}$ que ocorreu foi antes um fortalecimento e uma confirmação do cristianismo puritano, com o desenvolvimento de várias comunidades religiosas que preconizavam uma religião de colonização, de afirmação do grupo étnico e da ordem civil de uma democracia de proprietários. Não se desenvolveram as determinações da Revolução Francesa, de um cristianismo comprometido com um processo de revolução social, e da revolução exigindo manifestações de religiosidade. Até o milenarismo, o misticismo e a religiosidade humanista se desenvolveriam nos Estados Unidos mais como consequência da influência francesa, do que como influência direta do espírito revolucionário da própria independência ou da tradição da Revolução Inglesa do século XVII. Ruth Bloch ${ }^{1}$ evidenciou, nesse sentido, a importância da visão religiosa da Revolução Francesa nos Estados Unidos.

Isto não quer dizer, especialmente, que as interpretações bíblicas não desempenharam um papel ideológico notável na Revolução Americana. Assim, por exemplo, o tema que encontraremos na Revolução Francesa, o de Samuel na imposição da monarquia como algo ímpio aos olhos de Deus, já tomou-se patente em várias ocasiões durante a Revolução Americana. ${ }^{2}$

A França manteve uma posição ambivalente em relação à Revolução Americana. Por um lado, mostrou-se entusiasta com o que significava a primeira transformação de uma sociedade rumo à democracia, aos direitos do homem e à liberdade ideológica e política; contudo, por outro lado, descobria o caráter conservador, e inclusive retrógrado - o caso da escravidão -, da sociedade formada nos Estados Unidos.

1 BLOCH, Ruth H., Visionary Republic, Cambridge, 1985. Cap. esp. "Francophilic Millenialism".

${ }^{2}$ MILLER, P., "Religion as Revolutionary Ideology", em HOWE, J. R., ed., The Role of ideology in the American Revolution, Nova Iorque, 1970.
Em algumas ocasiões, a França chegou a demonstrar até um reconhecimento oficial do valor da Revolução Americana para o povo francês, quando James Monroe visitou a Convenção Nacional da República Francesa na qualidade de ministro plenipotenciário dos Estados Unidos: "O povo francês não esqueceu de forma alguma que deve a iniciativa da liberdade ao povo americano", disse o presidente da Convenção. Declaração que coincidia com uma nova edição francesa de Senso Comum, de Thomas Payne. Tudo isso depois do Termidor. ${ }^{3}$ Alguns chegaram a atribuir a detonação da Revolução Francesa a um complô duplo, britânico e norte-americano. Pitt se vingaria da França por esta ter ajudado a independência americana. Sua política seria ajudar Felipe de Orleans e outros na organização de uma conspiração que enfraqueceria a França e a submeteria ao império econômico e político inglês. Por outro lado, Jefferson e outros americanos apoiariam La Fayette com vistas a obter uma república francesa solidária com a americana e virar a Europa a seu favor. ${ }^{4}$

A opinião de Volney sobre os Estados Unidos foi no sentido de desmistificar a revolução de independência. O autor, que visitara a Ásia e meditara sobre ela, não se deixou impressionar pela "novidade" da América: "apontava o erro novelesco dos escritores que chamam de povo novo e virgem uma reunião de habitantes da velha Europa: alemães, holandeses e, sobretudo, ingleses dos três reinos... Uma multidão de fatos omitidos ou desfigurados teria estabelecido entre a revolução da América e a nossa uma semelhança maior do que vulgarmente se supõe, tanto nos motivos como nos meios de execução, na conduta dos partidos, etc.”. Mas essas semelhanças eram desmistificadoras de ambas as revoluções. $\mathrm{O}$ autor das Ruínas encarava a euforia americana como fruto de sua situação mais isolada e plena de progressos contínuos. A revolução, advertia, transformara-se em reação, coisa que também parecia estar acontecendo na França à época de seu périplo norte-americano, que resumia magistralmente ${ }^{5}$ :

Vi no sul o regime escravista com seus efeitos morais; no oeste, o estado de uma sociedade nascente; no alto Canadá, os franceses de

\footnotetext{
${ }_{3}^{3}$ La Décade Philosophique, ano II, t. II, p. 246.

${ }^{4}$ DEVISE (?), Anecdotes inédites de la fin du 18e siècle, Paris, 1801, cap. 1.

5 MATHIEZ, A., ed., Lettres de Volney à La Revellière-Lépeaux 1795-98, Le Puy, 1910, pp.6, 10-11, 31,etc.
} 
Luiz XV transformados em semi-índios; no leste, os ingleses do século passado já configurados como nação velha, a única que parece ter aqui um caráter maduro.

Ademais, Colin Bonwick ${ }^{6}$ estudou recentemente os aspectos elitistas, aristocratizantes - para olhos europeus - da Revolução Americana, de tal modo que lhe pareceu necessário concebê-la como uma revolução nãodemocrática.

\section{DEÍSMO PATRIÓTICO E DEÍSMO POLÍTICO}

\section{A força da linguagem e a religião}

Bonneville ${ }^{1}$ atribuía a credulidade religiosa à tirania da linguagem. Procurava encontrar uma definição clara de Deus para poder referir-se a ela de maneira totalmente explícita. Entretanto, o que a maioria das religiões fazia com sua linguagem era justamente obscurecer a ideia de Deus. "Regeneremos o gênero humano com a mesma coisa que o criou, com a palavra". ${ }^{2}$ Bonneville afirmava, a partir desse propósito, que se o fanático e o crédulo confundem a ideia de Deus com uma linguagem obscura, o ateu, ao não reconhecer Deus, situa-se num nível infra-humano, pois não se compreende como palavra de Deus ${ }^{3}$ :

O homem, obra-prima da criação, vem imediatamente depois do orangotango... classificaria o ateu um pouco acima do orangotango, já que é capaz de falar, mas não entre homens, pois o germe de uma eternidade feliz, que deve engrandecer sua existência, purificar seu pensamento e torná-lo homem ainda não se desenvolveu nele. Não digo isto como uma afronta gratuita ao ateu, pelo contrário, reivindico para esses desditosos uma proteção especial das leis humanas; gostaria que fossem sempre tratados com indulgência, que se procurasse convencê-los, e não se tentasse convertê-los à força; gostaria que nenhuma barbárie fosse empregada contra eles para fazê-los compreender aquilo que não podem conceber melhor do que o orangotango.

Bonneville, em companhia de Fauchet, defenderia a abertura dos templos maçons e a revelação de todos os seus segredos, porque "nada dever ser ocultado a um povo livre". ${ }^{4}$ E, assim como Fauchet, estava convencido de que a maçonaria possuía o germe dessa religião diáfana e humanista.

${ }^{1}$ BONNEVILLE, Nicolas, De l'Esprit des Religions, 2 V., Paris, 1792 (2 ed.).

${ }^{2}$ Idem, cap. 10.

${ }^{3}$ Idem, caps. 10 e 23

${ }^{4}$ Idem, caps. 10 e 91.
${ }^{6}$ BONWICK, C., "The American Revolution as a Social Movement Revisited", em Journal of American Studies, pp. 3, 20, 355-373, 1986. 
Bonneville prossegue sua argumentação criticando a hipocrisia religiosa e o ministerialismo eclesiástico por sua mesquinharia, duplicidade e pela teleologia material de sua teologia moral. Assim, na tradição deísta do Iluminismo, o ateísmo é criticado por sua inferioridade moral e por sua incompreensão do verbo divino, e o catolicismo, por sua predisposição à hipocrisia:

Naqueles tempos, devido à simplicidade dos oprimidos, e à duplicidade dos opressores, ainda não se pintava, ainda não se gravava, ainda não se escrevia, ainda não se ensinava, ainda não se recitava, apenas se adivinhava a história.

Ó, vós que morrestes junto com a vitória sobre os grilhões partidos, vós que deixastes o sangue ainda vivo para acusar de frente os tiranos, saí de vossas tumbas, instruí-nos!

Porque ainda estamos nos dias da simplicidade e da duplicidade. Uns enganam o mundo fazendo-o crer no que eles mesmos não crêem. Outros, a maioria, enganam-se a si mesmos, não sabendo penetrar no que é crer; e outros exibem a frívola fé de não crer no que crêem porque não têm a coragem da incredulidade; e como se sua religião nascesse e tirasse o seu crédito da imbecilidade, esquecendo que as almas dos imperadores e dos sapateiros são tiradas do mesmo molde, atribuem-se, mediante uma graça especial e santamente sacerdotal, bens imaginários, fantásticos, futuros e ausentes; deixando pela metade, a todos os que receberam as ordens da fé, os bens essenciais, manejáveis, palpáveis, o fruto de seus trabalhos, de seu suor e os presentes mais ricos que a natureza nos concede a todos por igual.

Duquesnoy, jacobino bastante radical, está entre os que pedem com mais convicção a inclusão de um preâmbulo religioso na Declaração dos Direitos Humanos pelo que de universal e imponente possui a linguagem religiosa ${ }^{5}$ :

Senhores, a Religião não tem outra base, outro esteio, senão a Moral; seria um propósito absurdo e perigoso separá-las ou distingui-las. O Povo ainda não viu suficientemente a Religião sob este ângulo; nós devemos efetuar tal apresentação, devemos acumular tudo o que causa impressão nos homens, tudo o que os obriga a respeitarem-se mutuamente. E, deste ponto de vista, desejaria que a Declaração dos Direitos Humanos começasse com uma ideia religiosa grande e

\footnotetext{
${ }^{5}$ Opinion de M. Duquesnoy sur les Projets de Déclaration de Droits, Versalhes, s.d., p. 3.
}

majestosa, aplicável a todos os cultos, a todas as opiniões, a todos os climas; que, por exemplo, apenas da ideia da existência de um Deus fossem derivadas todas as verdades morais e práticas que entrarão na Declaração.

Conheço tudo que possa se opor a esta ideia, sei que é possível, sobretudo, dizer que as verdades morais são independentes da existência de um Deus; pode sem dúvida ser assim, já que as relações dos homens entre si são independentes dessa existência; mas eu desejaria que as verdades morais que vamos estabelecer entrassem nos espíritos e nos corações por todas as vias; desejaria que, não havendo opositores ao conteúdo desta questão, conhecêssemos o inestimável êxito de concordarmos todos quanto à forma.

François Boissel $^{6}$ atribui à convenção linguística a existência do vocábulo Deus com o-sentido de algo inexprimível e mesmo assim tender a aproximá-lo por meio de atributos mais cognoscíveis e, sobretudo, antropomórficos: "Deus... é o termo de nossa língua que serve para exprimir o princípio único ou a causa primeira de tudo o que existe". Ao mesmo tempo, vincula o espírito de religiosidade às exigências de justiça, atacando a propriedade e o comércio materializante:

Que inconvenientes puderam nascer do estabelecimento de espécies em ouro e prata?... Tratando-se do tipo mais cômodo de propriedade, por poder-se adquirir com ela todo o resto, esse estabelecimento deve ser considerado o mais capaz de contentar o egoísmo e de mobilizar todas as faculdades da alma e do corpo, de inventar e empregar todos os meios possíveis para enervar os homens, degradá-los, fazê-los mentir, roubar, envenenar, assassinar e destruir, como se pratica na atualidade e praticou-se em todos os tempos, de acordo com o testemunho de nossos melhores escritores...

Como pode ser que depois de experimentar tantos males e adquirir tantas luzes, ainda se considere a propriedade o fundamento ou base da civilização? Deve-se a que os que melhor sentiram os seus desastrosos inconvenientes não conheceram os verdadeiros princípios do direito natural, ou não os apreenderam o bastante para convencerse e provar que o direito de propriedade não pode ser senão uma monstruosidade na ordem social, do mesmo modo como na ordem

${ }^{6}$ BOISSEL, François, Le Catéchisme du Genre Humain, 1789, pp. 143 e segs. Impresso dois meses antes da queda da Bastilha. 
física, e que uma monstruosidade não pode ser a base ou o fundamento da civilização.

Boissel afirma que a natureza não cria, de forma alguma, proprietários e marginalizados, e que a religião do gênero humano, de conformidade com a natureza, deve recusar as tergiversações a que a sociedade a submete. Critica Rousseau porque este, depois de lamentar a desigualdade humana, não procura autênticos remédios para corrigi-la. Afirma que as ideias religiosas serviram, mais que qualquer outra coisa, para adular e fortalecer os "grandes proprietários" e fazer com que fossem temidos, chegando a sacralizar a propriedade. Considera o matrimônio um resultado do exercício da propriedade:

... os matrimônios não podem ser senão atentados formais à liberdade dos homens, e sobretudo das mulheres, enquanto não passam de divórcios do resto do gênero humano e de formidáveis alianças contra seus semelhantes.

Entre um deísmo com extremos de moral social rigorosa e o respeito para com a religião estabelecida, levando-se em conta a força moral - e portanto também política - de sua linguagem, de seus costumes de comunicação social, o credo jacobino irá se adaptando ao uso de Robespierre: um deísmo patriótico e político-moral, mais do que filosófico ou de evocação do paganismo clássico menos patriótico, tolerante com as demais religiões.

Vejamos dois exemplos da conjugação destas duas tendências: a primeira onde a sociabilidade rousseauniana, a imortalidade da alma e a virtude são teoria e prática inseparáveis do bom jacobino, aquele cuja revolução impunha virtudes, ao passo que as outras só exigiam ambição, como dizia Robespierre?

Os verdadeiros jacobinos são aqueles cujas virtudes privadas garantem com segurança as virtudes públicas. Os verdadeiros jacobinos são aqueles que professam abertamente os artigos que não devem ser considerados dogmas de religião, e sim sentimentos de sociabilidade, sem os quais, diz Jean-Jacques, é impossível ser um bom cidadão. A existência da Divindade, da vida futura, da santidade

${ }^{7}$ AULARD, F.-A., La Société des Jacobins. Recueil de documents pour l'histoire du Club des Jacobins de Paris, Paris, 1897, pp. 247, etc. do contrato social e das leis: sobre essas bases imutáveis da moral pública deve assentar-se a nossa República una, indivisível e imorredoura. Unamo-nos todos em torno desses sagrados princípios. Não se pode obrigar ninguém a crer neles; mas que aquele que ousar dizer que não crê saiba que está se levantando contra o povo francês, o gênero humano e a natureza!

Somente os conspiradores podem buscar refúgio no aniquilamento total de seu próprio ser. A virtude tem a necessidade e a consciência de sua existência imortal. Vós, ilustres mártires da causa do povo, não perecereis de todo; a imortalidade vos reclama. E vós, tiranos, não espereis vosso descanso eterno; a imortalidade também vos reclama para castigar vossas extensas felonias.

Tal é, cidadãos representantes, a profissão de fé dos jacobinos de Paris e, ousamos dizer, dos jacobinos da França!

A segunda tendência, de respeito para com as religiões arraigadas no povo e especialmente para com sua linguagem, seus sinais característicos, é exemplificada pela oposição de Danton às "pantomimas antirreligiosas" dos padres apóstatas, que se apresentavam à Convenção e abjuravam o catolicismo com ostentação e fanfarronice. Danton pede que essas demissões sejam apresentadas ao Comitê de Salvação Pública com mais discrição, e não no meio da sala da Convenção ${ }^{8}$ :

Há um decreto que diz que os sacerdotes que abdicarem irão depositar sua renúncia junto ao Comitê. Peço a execução deste decreto, já que não duvido que numerosos indivíduos se apresentem para abjurar sua seita. E não se deve ficar extasiado ante o desfile de homens que não fazem mais que seguir a corrente. Não queremos bajular ninguém. Se não tecemos loas ao emprego do erro e do fanatismo, tampouco queremos fazê-lo ao da incredulidade: queremos servir ao povo. Peço que cessem as pantomimas antireligiosas dentro da Convenção. Que os indivíduos que queiram depositar no altar da pátria os despojos das igrejas não façam disto um jogo ou um troféu. Nossa missão não é receber continuamente delegações que repetem sempre as mesmas palavras. Há um fim para tudo, inclusive para as felicitações. Peço que se ponha termo a isto já.

\footnotetext{
${ }^{8}$ Le Moniteur Universel, $\mathrm{n}^{\circ}$ 68, 28-XI-1793
} 
Mas há motivos ainda mais sérios, na perspectiva político-moral de Robespierre, para se ter uma consideração especial com a Igreja Católica9:

Comparando-se os nobres aos eclesiásticos, diz-se que toda vantagem recai sobre os primeiros.

Não penso assim, e eis por que: o nobre é um homem cujas vantagens são todas políticas. Tem-nas desde seu nascimento, e o hábito das distinções o leva a desprezar tudo que não seja do seu nível, como ele chama.

Em compensação, entre os sacerdotes existiam dois tipos de homens. O chamado baixo clero conta com homens comprometidos com a revolução através de sacrifícios incessantes.

Nesta mesma sociedade (dos jacobinos) há, por exemplo, o que acaba de descer da tribuna e foi mártir da liberdade.

Os nobres, sempre vinculados às cortes estrangeiras, desprezaram continuamente os curas, a quem no entanto admitiam e incluíam em seu partido.

Seria possível expulsar, sem inconveniente algum, todos os nobres das Sociedades Populares. Seria possível expulsá-los de qualquer lugar. O mesmo não aconteceria com os sacerdotes. O campo, não se deve esquecer, foi induzido ao erro pelos inimigos do povo, sempre atentos para tirar proveito do menor de nossos erros.

Lembrai-vos das desgraças decorrentes das medidas violentas tomadas contra os sacerdotes em certas regiões e temei que se reproduzam!

Se existirem boas razões para se oporem ao que acabo de dizer, rogo que minha proposta seja combatida; se não for o caso, peço que não sejam aplicadas com excessiva severidade as medidas que em si mesmas são úteis, mas que não estariam isentas de abusos. (Recordemos que Danton é "o indulgente" aos olhos de Robespierre, em relação aos aristocratizantes, é claro, e não aos padres.) Nunca pretendi servir aos agentes da Prússia e da Inglaterra numa moção patriótica como esta.

${ }^{9}$ Le Moniteur Universel, $\mathrm{n}^{\circ}$ 89, 19-XII-1793, p. 691.
A questão da associação de determinadas posições políticas ou morais à linguagem adquiriu um sentido mais direto e discriminatório no debate sobre o valor das línguas regionais. A desvalorização das culturas das regiões ou nações dentro do território francês iria, significativamente, de par com os ataques às supostas intenções dos estrangeiros. O chauvinismo emergia pelos dois lados da nova nação francesa. Assim, enquanto Cloots e Payne eram acusados em Paris, também em Paris desencadeava-se uma ofensiva linguística considerada aliada das ideias da Revolução. Foi assim que Barere, oriundo de Tarbes, advogado no Parlamento de Toulouse e juiz do tribunal de cassação dos Altos Pirineus, ou seja, com pouco "pedigree parisiense", expôs na Convenção o elo natural existente entre o fanatismo, a reação e determinadas línguas $^{10}$ :

O federalismo e a superstição falam o baixo-bretão; a emigração e o ódio à república falam alemão; a contrarrevolução fala italiano e o fanatismo, basco. Quebremos esses instrumentos de erros e preconceitos...

Deixemos que a língua italiana se dedique às delícias da harmonia e às expressões de uma poesia mole e corruptora.

Deixemos a língua alemã, pouco adequada a povos livres, até que seu governo feudal e militar, do qual é o órgão mais digno, seja aniquilado.

Deixemos a língua espanhola para sua Inquisição e suas Universidades, até que saiba exprimir a expulsão dos Borbons que destronaram os povos de todas as Espanhas.

Quanto à língua inglesa, que foi grande e livre no dia em que se enriqueceu com as palavras da majestade do povo, agora já não passa do idioma de um governo tirânico e execrável, idioma dos bancos e das letras de câmbio.

Nossos inimigos haviam feito da língua francesa a língua das cortes; haviam-na envilecido. Nós devemos torná-la a língua dos povos, e assim será honrada.

A língua que emprestou seus sons à liberdade e à igualdade... deve transformar-se na língua universal... é preciso fazer com que seja falada em todo o território francês a língua na qual foi escrita a Declaração dos Direitos Humanos.

${ }^{10}$ Idem, no 100 , pp. $319-320$. 


\section{Robespierre: resistência republicana e condicionamento moral do capitalismo}

A religião e a religiosidade conforme foram empregadas por Robespierre constituem todo um complexo que talvez seja a maior originalidade da Revolução Francesa em termos de uma teoria crítica da história. Porque é Robespierre que, apesar de seu curto mandato, tenta implementar recursos ideológicos e políticos diante das consequências do capitalismo moderno que se evidenciam a longo prazo. Porém, antes de abordar o núcleo dos projetos de Robespierre, devemos considerar algumas questões relativas a seu contexto.

Com Robespierre chegará ao auge a crítica do ateísmo como fenômeno associado à aristocracia e ao estrangeirismo, ou seja, ao egoísmo das classes privilegiadas e aos interesses antipatrióticos. Essa será uma das formas de devolução da religião ao povo, no intuito de desmoralizar suas elites prepotentes e a internacionalização perigosa da direção dos objetivos revolucionários. Como a França se achava em guerra com o exterior e essa guerra estava entremeada com uma contrarrevolução interna, os fatos davam mais força à crítica de intenções elaborada por Robespierre. É assim que se deve entender o ataque de Robespierre a Cloots ${ }^{1}$ :

Cidadãos, consideraríeis patriota um estrangeiro que quer ser mais democrata que os franceses e que tanto é visto na Planície como embaixo da Montanha (quer dizer, entre os ricos e longe dos jacobinos)... Jamais se declarou defensor do povo francês, mas sim do gênero humano.

A guerra da república francesa muda o sentido do humanismo universalista de Cloots, na concepção de Robespierre. A defesa da pureza revolucionária deve passar forçosamente pela do povo francês, em sentido concreto, enquanto este se encontra lutando em todas as suas frentes. Da mesma maneira, os ataques de Robespierre a Cloots, Fauchet e Desmoulins se inscrevem na perseguição contra políticas abstratas ou nebulosas que parecem escapar aos compromissos concretos com a guerra ou com a economia nacional. Dadas as circunstâncias, Robespierre interpreta as

${ }^{1}$ Le Moniteur, t. 18, p. 666 (BHVP). formas mais radicais e transcendentes da revolução como ameaças à defesa da soberania e homogeneidade do território francês e à força da economia de um estado novo, assediado, e que não inspira confiança a muita gente.

Tampouco tinha cabimento uma revolução pela metade, uma revolução comprometida com as elites, que conservariam privilégios na sociedade. Para Robespierre, apenas Rousseau tinha as ideias claras acerca de uma sociedade sem privilégios, embora com méritos e propriedades. Helvetius já representava a corrupção em virtude de sua teoria egoísta da sociabilidade. Mirabeau era a personificação do egoísmo aristocratizante, da alternativa da recriação de privilégios na nova sociedade emergente com a Revolução. Essas tendências somavam-se às anteriores na lista das ameaças que era preciso aniquilar para o bem da república francesa.

Alguns jacobinos chegaram a propor uma guerra aberta contra todos os ateus, aristocratizantes e estrangeiros que parecessem encarnar todas essas ameaças. Robespierre também quer ponderação nessa perseguição, com a qual concorda em parte. Assim, quando Jullien propõe a expulsão dos ateus da república, Robespierre se mostra mais criterioso. Estas são as palavras de Jullien:

Há homens que ousaram erigir a imoralidade em dogma e quiseram fazer do ateísmo um sistema. É contra esses homens abomináveis que os jacobinos dirigiram e ainda dirigirão seus esforços, E as sábias máximas jacobinas confundirão esses malvados.

Retrocedamos aos desditosos tempos da atroz guerra da Vendeia lembremos dos velhos, das mulheres, das crianças encorajando seus familiares a empunharem as armas para defender a pátria. Não teria sido um estímulo reconfortante se lhes tivessem dito: "Ide combater pela liberdade; se sobreviverdes à contenda, desfrutareis de vosso triunfo; mas se sucumbirdes, o nada vos aguardará na tumba". Ao invés disto, diziam-lhes com satisfação: "Ide, se perecerdes vítimas de vosso zelo, vivereis para sempre no coração de vossos irmãos, e vos lançareis no seio da Divindade". Depois destas palavras de consolo, nossos defensores voavam ao encontro do canhão inimigo e em meio aos perigos maiores não viam a morte: viam apenas a imortalidade. Um homem que não crê na imortalidade seria culpado se quisesse 'propagar sua doutrina. Devem ser proclamados traidores

${ }^{2}$ AULARD, F.-A., La Société des Jacobins, Paris, 1897, t. 6, p. 134. 
da pátria todos aqueles que quiserem tirar do homem o germe mais poderoso das virtudes, do heroísmo e do patriotismo.

Robespierre respondeu a essa proposta em termos moderados, sugerindo que se mantivesse apenas nos escritos de Rousseau a expulsão dos ateus da república:

Este princípio... não deve ser adotado: inspiraria pavor demais a uma grande multidão de imbecis ou homens corruptos. Não sou a favor de persegui-los, só se deve fazê-lo com os que conspiram contra a liberdade.

Couthon vem confirmar a importância política do ataque à religião como recurso da contrarrevolução dos aristocratizantes:

Penso como Robespierre, o ateísmo era o meio com o qual mais contavam os conspiradores contrarrevolucionários. Quando a Convenção trabalhava na grande e sublime obra da Constituição, Danton achava errado que os representantes declarassem que trabalhavam na presença do Ser Supremo.

Saint Martin defendia a artificialidade do ateísmo nos seguintes termos:

Não existe um só homem para quem o ateísmo e o materialismo sejam ideias mestras. Tanto uma como outra são apenas ideias secundárias, ideias subtraídas de uma verdade radical que inicialmente ele mesmo contemplara de forma complacente e depois permitiu que se afastasse dele por desespero de apreendê-la; mas sente-a como tão natural, sempre sente saudade dela em segredo e nada, nem a própria virtude, pode substituí-la em seu coração.

Aos que duvidam da fé de Robespierre, pode-se retorquir com essas palavras de Saint Martin - personagem alheio à trajetória ideológica do Incorruptível. Quer dizer, a história e a consciência, expressas como o desejo mais plausível de sociabilidade, falam da fé em Deus, sem a qual nenhum esforço de consciência e de convivência teria sentido. Assim podemos começar a entender o deísmo de Robespierre não como manobra de política interna, mas como recurso primordial para unir a convivência à consciência. Assim sendo, Robespierre é deísta "à maneira de Rousseau" e

\footnotetext{
${ }^{3}$ SAINT MARTIN, C.C. de, L'Homme de Désir, Metz, 1802, vol. II, p. 45.
}

espiritualista como Fouché ao não admitir que a morte seja um sono eterno; filósofo, crê como Voltaire que o povo necessita de uma fé e que "se Deus não existisse, seria preciso inventá-lo", sob pena de transtornar toda a moral e toda a ordem social (aqui Leflon parece mais maquiavélico do que pensamos que Robespierre pretendia). Suas convicções pessoais decidirão, em grande medida, a sua ação. A política também intervém, pelo menos a política interna. Será que as massas trabalhadoras, especialmente as camponesas, estavam maduras para a descristianização? M. Aulard pensou que sim e M. Guérin o afirma (embora Guérin considere que teria sido necessário melhorar "a condição humana até permitir que o homem prescinda de Deus"). ${ }^{4}$

Seja como for - baseado na fé ou no cálculo - Robespierre e sua política religiosa vão se centrando numa dialética peculiar a certa religiosidade moderna: por um lado, considera-se a ideia de Deus e da religiosidade tão enraizada na consciência popular que sua perturbação faz temer a destruição do amor-próprio ou da dignidade da própria educação moral, desencadeando o egoísmo incivil. Por outro lado, quando esse egoísmo é propriedade inerente ao sistema social, como sucede com o capitalismo, a ideia de Deus e de sua justiça se transforma num ingrediente político imprescindível: governar em nome da moral o desenvolvimento de um sistema imoral.

Esse segundo paradoxo será explorado por Sade com muitíssimo engenho. Entretanto, Robespierre parece obstinado em moralizar o que não é moralizável, e já que não considera a revolução do sistema social, dedicase a perseguir todos aqueles que o dão a entender em demasia. Facilmente portanto, essa política será interpretada como ditadura pessoal.

Da mesma forma, Robespierre enfrenta o problema político de manter uma revolução interna e uma guerra externa. Leflon caracteriza assim a situação $0^{5}$

A salvação pública exige que não se provoque o aumento dos perigos da república, já por si graves, com um acréscimo de uma guerra religiosa; o campo se irrita, e mais do que nunca convém controlar seus nervos quando a crise dos víveres impõe, com a lei do preço

${ }^{4}$ LEFLON, Jean, La crise révolutionnaire (Histoire de l'Église), Paris, 1949, p. 121. ${ }^{5}$ Idem, op. cit., p. 121. 
máximo, um regime de economia dirigida muito impopular entre os camponeses. Será que o Incorruptível exagerou as reações da opinião pública? Fez delas um pretexto para mascarar um movimento de reação burguesa contra os proletários e os peões?

Robespierre não podia controlar nem dirigir o capitalismo sem reformar a propriedade ou o mercado, e tampouco podia evitar as consequências sociais e morais do próprio capitalismo se este não fosse reformável e reformado. Assim sendo, optou por uma correção radical das aparências, que seria interpretada como um despotismo absurdo ou uma iniciativa ditatorial. Depois do termidor, embora as coisas não tenham mudado - nem antes haviam evoluído - o suficiente para falar-se de reação, as aparências foram mais preservadas, dando-se maior vigor à moral do negocismo, que caracterizaria a vida pública pós-revolucionária.

Mas decidamos melhor acerca desta reflexão recorrendo aos textos de Robespierre $^{6}$ :

... Sim, invocar o nome da Providência e emitir uma ideia sobre o Ser Eterno que influi de maneira essencial nos destinos das nações, que me parece zelar de forma particular sobre a Revolução Francesa, ${ }^{7}$ não é uma ideia aventurosa, mas significa exprimir um sentimento de meu coração, um sentimento que me é necessário. E como não seria necessário a mim, que entregue na Assembleia Constituinte a todas as paixões e a todas as vis intrigas e rodeado de numerosos inimigos, pude me sustentar com a minha alma? Como teria podido cumprir essas tarefas sobre-humanas se minha alma não estivesse elevada? Sem mais questionar a esta ideia tão reconfortante, o sentimento da divindade me ressarciu de todas as vantagens apresentadas pelos que queriam trair o povo ... E ainda dizem que eu havia injuriado as Sociedades Populares. Ah! por certo, senhores, invoco-vos a todos como testemunhas, se há uma censura que não mereço em absoluto é esta que me fazem de injuriar o povo, e estes agravos consistem em nem mais nem menos que ter citado a Providência e a Divindade nas Sociedades. Certamente, confesso, o povo francês está na Revolução por algo importante. Sem ele, ainda estaríamos sob o jugo do

6 AULARD, F.-A., La Société des Jacobins, Paris, 1889, t. 4, 26-III-1792, p. 699: Robespierre entre os jacobinos replicando a Guadet.

Lembremos que esta interpretação providencialista também será adotada por de Maistre, embora a serviço do conservadorismo contrarrevolucionário. despotismo. Sinceramente vos digo que todos os que se encontram acima do povo teriam renunciado de bom grado à ideia de Divindade se isso lhes tivesse rendido as vantagens do despotismo. Porém, será que é injuriar o povo e as Sociedades afiliadas dar-lhes a ideia de uma Divindade que, ainda segundo meu sentimento, ajuda-nos de modo tão feliz? Sim, peço perdão aos que forem mais sábios do que eu neste assunto. Mas, quando vi tantos inimigos erguidos contra o povo, tantos homens pérfidos empenhados em destruir a obra do povo, quando vi que o próprio povo estava subjugado e se via obrigado a colocar-se nas mãos dos maus, então acreditei mais que nunca na Providência, e não é possível, de modo algum, que tenh insultado nem o povo, nem as Sociedades Populares ao falar como falei sobre as medidas que era preciso tomar na guerra e na paz ...

Ainda respondendo a Guadet, Robespierre prossegue em sua afirmação da tolerância e da fé deísta na sociedade jacobina, presidida naquele momento por Anacharsis Cloots ${ }^{8}$ :

Partiu-se do princípio de que acolhendo umas oferendas cívicas a Convenção proscreveu o culto católico. Não, a Convenção não deu de forma alguma esse passo temerário. A Convenção nunca o faria Sua intenção é manter a liberdade de culto que já proclamou, também a de reprimir os cultos cujos abusos possam perturbar a ordem pública; não permitirá que os ministros pacíficos do culto sejam perseguidos; e os castigará com severidade cada vez que ousarem se prevalecer de suas funções para enganar os cidadãos e incitar aos preconceitos ou ao realismo contra a república. Alguns sacerdotes foram denunciados por terem celebrado a missa: celebrarão ainda mais se alguém os impedir. Quem quer impedir é mais fanático do que quem celebra a missa. ${ }^{9}$

Mas há homens que querem ir mais longe; que, a pretexto de destruir a superstição, pretendem criar uma espécie de religião do próprio ateísmo. ${ }^{10^{3}}$ Qualquer filósofo ou qualquer indivíduo pode adotar a esse respeito a opinião que bem lhe aprouver. Quem ousar fazer disso um crime é um insensato; mas o homem público, o legislador, seria cem vezes mais insensato se adotasse sistema igual. A Convenção

\footnotetext{
${ }^{8}$ Le Moniteur Universel, $\mathrm{n}^{\circ}$ 66, 26-X-1793, p. 508.

9 Nesta consideração, a tolerância que Robespierre defende parece de acordo com a de Voltaire, quando este elogiava os romanos por não perseguirem os fanáticos e os loucos.

${ }^{10}$ Este argumento também era utilizado pelos jesuítas.
} 
Nacional o aborrece. A Convenção não é um escritor de livros, um autor de sistemas metafísicos; é um corpo político e popular encarregado de impor o respeito não apenas aos direitos como também ao caráter do povo francês. Não foi em vão que a Convenção proclamou a declaração dos direitos humanos em presença do Ser Supremo.

Talvez se diga que tenho opiniões tacanhas, preconceitos - que mais? - , fanatismo

Mas já disse que não falava nem como indivíduo nem como filósofo sistemático, e sim como representante do povo. O ateísmo é aristocrático; a ideia de um grande Ser, que zela pela inocência oprimida e castiga o crime triunfante, é do povo (aqui Robespierre suscitou vivos aplausos). O povo, os infelizes, me aplaudem; se eu encontrasse censores, seria entre os ricos e os culpados. Desde o colégio fui um católico bastante precário; mas nunca fui nem um amigo frio nem um defensor infiel da humanidade. Com a mesma fidelidade sinto-me ligado às ideias morais e políticas que acabo de expor. Se Deus não existisse, seria preciso inventá-lo.

Falo de uma tribuna onde o imprudente Guadet ousou acusar-me pelo crime de pronunciar a palavra providência. E em que tempo? Quando o coração se sentia ferido por todos os crimes dos que nos faziam ou suas vítimas ou testemunhas; quando, vertendo lágrimas impotentes e amargas sobre a miséria do povo eternamente traído, eternamente oprimido, procurava elevar-me acima da turba impura dos conspiradores que me rodeavam, invocando contra eles a vingança celeste, na falta da ira fulminante do povo! $!^{11}$ Esse sentimento está gravado em todos os corações sensíveis e puros; sempre animou os magnânimos defensores da liberdade. Enquanto os tiranos gozarem da existência, será um consolo doce no coração dos oprimidos; e se algum dia renascesse entre nós a tirania, que alma virtuosa e enérgica, ante esse triunfo sacrílego, não oraria em segredo à justiça eterna que parece ter promulgado a sentença de morte de todos os tiranos? Ao menos parece-me que o último mártir da liberdade exalaria sua alma com um sentimento mais doce se pudesse repousar com essa ideia tão consoladora. Este é o sentimento da Europa e do

${ }^{11}$ A ideia de Deus parece desenvolver a linguagem mais expressiva - sagrada - para conter - envergonhar - o cinismo da opressão. A humanidade ideal não é melhor para a humanidade real do que um Deus mais real: pai, rei, senhor, irmão. universo; e é o do povo francês. Este povo não está entregue nem aos curas, nem à superstição, nem às cerimônias religiosas, mas sim ao culto de si mesmo, quer dizer, à ideia de um poder incompreensível, terror do crime e esteio da virtude, ao qual gosta de prestar homenagem. Reverência que é anátema à injustiça e execração do crime triunfante.

Se o filósofo pode fundar sua moralidade em outras bases, guardemonos aos menos de ferir esse instinto sagrado e esse sentimento universal dos povos. Que gênio pode, por um só instante, substituir com suas invenções essa grande ideia protetora da ordem social e de todas as virtudes particulares? ${ }^{12}$

Não vede a cilada que lhes armam os inimigos da república e os covardes emissários dos tiranos estrangeiros? Apresentando como opinião geral os caprichos de alguns indivíduos e sua própria extravagância. querem nos tomar odiosos aos demais povos, para firmar os tronos vacilantes dos maus que os oprimem. Qual foi o momento que escolheram para essas maquinações? $\mathrm{O}$ da derrota ou da fuga de seus exércitos aliados em virtude do gênio do exército republicano, o momento em que querem sufocar os murmúrios dos povos cansados de sua tirania ou indignados com ela; o momento em que instigam as nações neutras e aliadas da França a que se declarem contra nós. Os covardes não querem reconhecer as calúnias grosseiras que proferiram e que toda a Europa detesta por sua impudicícia e tentam, valendo-se dos preconceitos ou das opiniões religiosas, afastar de vós os princípios da moral e do interesse comum que vos conduzem à causa santa e sublime que defendemos. ${ }^{13}$

12 A religião é, ao mesmo tempo, a garantia da ordem social e da moral particular, ambas tratadas por Robespierre como estreitamente vinculadas entre si e imprescindíveis para a constituição e o exercício da política.

O "imoralismo" (para a moral robespierriana) da Convenção desembocando no Diretório seria a consequência do abandono dessa religiosidade que procurava impedir o triunfo desrespeitoso ao novo apogeu capitalista.

${ }^{13} \mathrm{O}$ ateísmo é, assim, apresentado como estratégia de desmoralização. Robespierre defende o armamento religioso e patriótico da república. Dentro do país, o ateísmo é forçosamente aristocratizante: só o aristocrata pode conceber o vazio ante a virtude indefesa e a alma oprimida. É a necessidade sagrada de justiça e salvação que faz Robespierre exclamar que se Deus não existisse seria preciso inventá-lo. Por outro lado, a religião católica deve ser 
Repito: não devemos temer outro fanatismo a não ser o dos homens imorais, a soldo das cortes estrangeiras empenhadas em insuflar o ódio e dar à nossa revolução o verniz da imoralidade, que na verdade é a característica própria de nossos covardes e raivosos inimigos.

Robespierre $^{14}$ procura aplicar seu moralismo que condiciona a política como contrapartida à corrupção da expressão religiosa e da ordem social das monarquias europeias. Ele tenta levar à prática uma teoria que se quisera confundir com um sonho:

... Deus criou as feras; mas os reis são a obra-prima da corrupção humana. Se invocam o céu, é para usurpar a terra; se nos falam da Divindade, é para colocar-se em seu lugar. São eles que provocam as preces dos pobres e os gemidos do desgraçado; eles mesmos são os deuses dos ricos, dos opressores e dos assassinos do povo. Honrar a Deus e castigar os reis é a mesma coisa. E que povo prestou culto mais puro que o nosso a este grande Ser, sob cujos auspícios proclamamos os princípios imutáveis de todas as sociedades humanas? As leis da justiça eterna haviam sido chamadas com desdém de sonhos das pessoas honradas; nós, em grande parte, tornamo-las realidades. A moral estava nos livros dos filósofos; nós a colocamos no governo das nações. A sentença de morte dos tiranos dormia esquecida nos corações abatidos dos tímidos mortais; nós a executamos. $\mathrm{O}$ mundo pertencia a duas ou três raças de tiranos, como os desertos da África pertencem aos tigres e às serpentes; nós o restituímos ao gênero humano.

Sem a virtude exercida como ação pública, como forma de condicionar e inclusive ameaçar a política, a república é pouco mais que ficção. Robespierre tenta condicionar moralmente o edifício transcendente da sociedade e da economia burguesas sem destruir sua estrutura. Mas $\mathrm{O}$ que tem acontecido é que precisamente essa estrutura é imposta como condicionante de todo o resto. A tentativa de Robespierre, solitária e desconfiada, fracassará. Robespierre justifica-se ante essa possível acusação elemento importante do "caráter do povo francês".

${ }^{14}$ Le Moniteur Universel, 7-XII-1793, p. 596. interpretando o terror como um exercício mais diligente e implacável da justiça $^{15}$ :

... No entanto deveis regular vossa conduta conforme as circunstâncias tormentosas em que se encontra a república. O plano de vossa administração deve ser o resultado do espírito do governo revolucionário combinado aos princípios gerais da democracia...

Mas qual é o princípio fundamental do governo democrático ou popular, quer dizer, a mola mestra que o sustenta e o põe em movimento? É a virtude: estou falando da virtude pública que operou tantos prodígios na Grécia e em Roma... Não apenas a virtude é a alma da democracia, como só pode existir nesta forma de governo. $\mathrm{Na}$ monarquia conheço apenas um indivíduo que possa amar a pátria e que para tanto não necessite da virtude: é o monarca; isto porque, de todos os habitantes de seus estados, o monarca é o único que tem uma pátria...

Se na paz a mola mestra do governo popular é a virtude, na revolução o motor deste governo é ao mesmo tempo a virtude e o terror; a virtude sem a qual o terror é funesto, o terror sem o qual a virtude é impotente. O terror não é senão a justiça rápida, severa, inflexível, ou seja, emana da própria virtude...

Cloots, convém recordar aqui, queria aproveitar as ideias de MablyRobespierre a favor de um deísmo humanista com uma moral muito cristã, sem admitir a fé religiosa que ele supunha ${ }^{16}$ :

Os atributos de uma divindade fantástica na verdade pertencem à divindade política. Eu disse e repito que o gênero humano é Deus. Assim, os aristocratas são ateus. Quando falei do Povo-Deus, que tem na França seu berço e seu centro de comunhão, estava me referindo ao gênero humano regenerado..

A seguir, depois de abonar o centralismo e o antifederalismo de Robespierre, acaba enfrentando mais claramente as ideias do Incorruptível:

... A questão da existência de Deus (Theos) está mal colocada, já que antes é preciso saber se o Mundo (Cosmos) é uma obra. Interrogai,

${ }^{15}$ Le Moniteur Universel, ${ }^{\circ}$ 139, 7-XX-1794, pp. 402 e 404.

${ }^{16}$ Idem, no $120,30-\mathrm{IV}-1793$, c.p. 255. 
pois, antes, essa questão prévia e seguireis com a ordem do dia diante do silêncio estupefato de vossos adversários.

A natureza não produz nada; tudo que a compõe existe eternamente. O que chamamos vulgarmente de rebento da natureza é tão velho como sua mãe. Não tentemos explicar a existência de urna natureza incomensurável. Procurais o eterno fora do mundo. A mim já me compraz o Cosmos incompreensível. Deixemos ao visionário Malebranche seu Theos indefinível; concentremos todos os nossos pensamentos no espetáculo da natureza eterna. Algo existe eternamente, trata-se de uma simples verdade; não nos percamos nas especulações de uma natureza divina e criadora... o bom senso recusa a ideia de um primeiro motor de um movimento que é eterno.

Mas o que são todas as contemplações do cosmos ante o sofrimento dos inocentes? É deste segundo extremo que surge a maior ideia e a maior expressão de Deus. É este Deus que melhor pode satisfazer a razão humana. Robespierre não está sozinho nessa concepção inicial de uma religiosidade natural ${ }^{17}$ :

Ocultos inimigos do povo quiseram empurrá-lo para a anarquia e escravizá-lo de novo. A religião natural observa o equilíbrio justo entre a superstição e o ateísmo. Pois bem, eles quiseram conduzir o povo ao ateísmo que, paralelamente à superstição, está disposto a arrebatar-lhe a liberdade. Fizeram ainda mais: quiseram dividir o povo. Deviam mostrar-se perversos até que a presença de um Deus os importunasse, que a mera ideia de sua existência os fatigasse e tentassem aniquilá-la em todos os corações. Como não existiria um Deus? Quem nos teria concedido a liberdade? Sejamos justos e não temeremos o Ser Supremo; mas não o importunemos com desejos desonestos e indiscretos; falemos-lhe como se os homens nos escutassem, e vivamos com os homens como se Deus nos visse. Ergamos por toda parte templos à Razão. ${ }^{18}$ Mas seria à nossa razão fraca e vacilante, que cresce conosco, que se forma com as lições da experiência e declina com a velhice, que ergueríamos os templos? Poderíamos ter uma ideia tão louca e absurda neste século de luzes? Não, o povo não acreditou que edificava templos à sua razão; sem dúvida quis elevá-los a essa razão eterna que governa o mundo e que

\footnotetext{
${ }^{17}$ Idem, no 228 , p. 395.
}

${ }^{18}$ Aqui fica bem claro o deísmo do suposto ateísmo do culto à Razão. não é senão o Ser Supremo: é a Ele que devemos nossas homenagens.

Mas em Robespierre o deísmo será ainda mais caloroso e comprometido com uma moral social. No primeiro aspecto, se aproximará do deísmo rousseauniano de Saint-Pierre, Mercier ou Chevret, ${ }^{19}$ embora esses autores apareçam associados aos inimigos girondinos de Robespierre.

O compromisso de Robespierre com uma certa moral da vida pública não pode ser entendido fora do contexto da problemática humana em geral que representava o capitalismo nascente da época. Parece-nos que este é o argumento essencial de sua obra, apesar de algumas hesitações e contradições que, por outro lado, apresenta.

A força do sistema social capitalista tal como se desenvolve no transcurso da Revolução foi saudada até com otimismo e confiança ingênua:

... depois de nossa declaração solene de renunciar a todo espírito de conquista, a ciência diplomática reduziu-se praticamente à nulidade. Os contenciosos europeus já não nos concernem. Os comerciantes que vendem em qualquer lugar são os verdadeiros ministros do interior. Os negociantes milionários, os que percorrem o Levante, as Ilhas, as Índias, são nossos grandes embaixadores. ${ }^{20}$

Soboul $^{21}$ caracterizou a burocratização política como a cumplicidade mais efetiva do capitalismo no decorrer da Revolução. Soboul destaca, no texto de sua própria concepção marxista, a contradição entre o governo revolucionário, submetido a objetivos burgueses, e o apoio popular que recebe com outras expectativas, tudo isso sem uma clara demarcação de classes, interesses e consciências. A burocratização aparece então como a expressão sociológica da contrarrevolução: "paralisia gradual do espírito crítico e da combatividade das massas". No entanto, a visão de Soboul,

${ }^{19}$ CHEVRET, M.J., De l'amour et de sa puissance suprême, ou développement de ses oeuvres dans la nature et dans nos coeurs, Paris, 1791.

${ }^{20}$ VILLETTE, Charles, Lettres Choisies, Paris, 1792, p. 114.

${ }^{21}$ SOBOUL, A., "Robespierre ou les contradictions du jacobinisme", AHRF, no 231,1978, pp. 17-18. 
experiente e teoricamente impecável, não chega a identificar algo da mentalidade de Robespierre que nos parece importante, se é que existia, é claro, e que transformaria a contradição que Soboul, ademais, aponta: a de defender uma nação mantendo o poder de produção em relação às outras, que dizer, sem alterar sua unidade e competitividade no cenário internacional (problema próprio de todas as revoluções com guerra) e, ao mesmo tempo mitigar, até chegar à reforma revolucionária, as consequências desta manutenção ou desenvolvimento, consequências gerais do capitalismo moderno.

Assim, como talvez deixe entrever a citação de Michelet que conclui o artigo de Soboul, ${ }^{22}$ Robespierre não teria utilizado - como comentava Marx - a ideologia da igualdade e da fraternidade para travestir o capitalismo nascente, mas para tentar condicionar moralmente a política do capitalismo que estava se desenvolvendo e difundindo com horrorosa impunidade e que repelia - como em tantas ocasiões - mais os preparativos de reforma que os de revolução, por sentir-se mais preparada para lutar com uma contrarrevolução do que para enfrentar a reforma de seus procedimentos, reforma que incessantemente deve limitar os atributos que transcendem por demais a vida de cada ser humano, os atributos do capitalismo.

Robespierre não acreditava na igualdade de riquezas, mas tampouco no desamparo da pobreza: "trata-se antes de tomar a pobreza honrosa, e não de proscrever a opulência". ${ }^{23}$ Neste sentido, defende a reforma da propriedade na Constituição do ano II:

Multiplicastes os artigos para assegurar maior liberdade ao exercício da propriedade, mas sem dizer uma palavra sobre como determinar sua natureza e legitimidade, de maneira que vossa declaração parece feita não para os homens, mas para os ricos, para os açambarcadores, para os agiotas e para os tiranos.

Depois de ter dito isto, Robespierre propõe esclarecer que o direito de propriedade está limitado pelos demais direitos humanos, quer dizer, que não pode prejudicar "nem a segurança, nem a liberdade, nem a existência,

\footnotetext{
${ }^{22}$ Idem, op. cit., p. 19.

${ }^{23}$ Le Moniteur Universel, $\mathrm{n}^{\circ}$ 115, 25-IV-1793.
}

nem a propriedade de nossos semelhantes". Qualifica de "ilícita e imoral" toda prática que viole esses princípios.

Além dessa interpretação da igualdade, Robespierre tem outra, não menos interessante, da fraternidade. Antes da experiência mais saturada de guerras internacionais, propunha uma conclamação a todos os cidadãos do mundo para que colaborassem na luta contra a tirania, criando uma solidariedade internacional da qual ele mesmo em breve desconfiaria gravemente:

"Os homens de todos os países são irmãos, e os diferentes povos devem ajudar-se mutuamente segundo seu poder, assim como os cidadãos de um mesmo estado". "Aquele que oprime uma nação declara-se inimigo de todas". "Os que fazem a guerra a um povo para deter o progresso da liberdade e aniquilar os direitos humanos devem ser perseguidos por todos, não como inimigos comuns, mas como assassinos e bandidos rebeldes". "Os reis, os aristocratas, os tiranos, sejam quem forem, são escravos rebelados contra o soberano da terra, contra o gênero humano e contra a legisladora do universo, a natureza".

Saint-Just ${ }^{24}$ acrescentava que as leis pretenderam apenas evitar o mal sem contar com outro apoio além da força. A virtude e as boas inclinações mantiveram-se independentemente das leis. Sem que essas disposições animem o legislador e o político, as leis, embora mantidas com a força, carecerão do vigor sólido e auto-suficiente da harmonia.

"A contrarrevolução está em todas as partes da economia política", 25 reconhecia Robespierre, e atacava a prepotência do capital financeiro sobretudo nas pessoas de Cambon, Mallarmé e Ramel, chefes das finanças. Tentava diferenciar os abusos dos especuladores e açambarcadores das práticas comerciais lícitas, questão que seria associada ao debate religioso:

... Pregação aberta do ateísmo, violências inesperadas contra o culto, provocações cometidas da forma mais indecente, perseguições dirigidas contra o povo a pretexto da superstição; sistema de fome, primeiro devido à apropriação, depois à guerra declarada contra todo

${ }^{24}$ Idem, p. 214.

${ }^{25}$ AULARD, F.-A., La Société des Jacobins, Paris, 1897, t. 6, p. 276. 
comércio lícito como pretexto para açambarcar; encarceramento de patriotas...

Unindo esses aspectos críticos do próprio contexto revolucionário às causas que são consideradas como as mais aceitas da Revolução, estaremos melhor preparados para examinar os importantes discursos de Robespierre, onde a religiosidade assume uma importância decidida e contundente.

Os redatores dos Tableaux historiques de la Révolution Française ${ }^{26}$ propunham em termos de causas da Revolução as já apontadas pelas opiniões mais influentes da época revolucionária: a desordem financeira como causa mais real e imediata; o desenvolvimento da instrução, o Iluminismo e a comunicação com a América setentrional independente como causas secundárias, embora também operacionais. Os iluministas, cuja influência sobre a consciência da iniciativa revolucionária era considerada mais importante, eram: Locke, Montesquieu, Voltaire, Raynal, Boulanger, Helvetius, Rousseau, Mably, Delolme, Adams, Condorcet...

Porém, há "uma causa muito mais real para qualquer um que conheça bem os homens: é a altivez, o fausto insolente, o desdém tão pronunciado da alta nobreza e do alto clero para com as outras classes de cidadãos, inclusive para com o que era chamado de nova nobreza e baixo clero; somese a isto a insolência da maioria dos ministros e seus agentes, o luxo dos bispos, o dos cortesãos, etc. $\mathrm{O}$ povo só sofria, era escarnecido e menosprezado, e com a palavra povo indicamos sempre a imensa maioria da nação".

Auger chegará a evocar as características das tragédias gregas para destruir o histrionismo e a falsidade dos grupos privilegiados ${ }^{27}$ :

É preciso esperar que a Revolução fortaleça nosso caráter e lhe dê mais energia... nosso caráter poderá endurecer-se no princípio,

${ }^{26}$ Collection Complète des Tableaux historiques de La Révolution Française, Paris, 1804, t. I, c.p. 34.

27 AUGER, A., De la Tragédie Grecque et du nom qu'on devroit lui donner dans notre langue, pour s'en faire une juste idée, Paris, 1792, p. 45. Os epítetos e os caracteres que os jacobinos atribuem aos contrarrevolucionários sugerem ou referem-se diretamente à imoralidade, derivada do abuso de algumas funções e da frivolidade egoísta do individualismo protegido. Trata-se de uma mescla da imoralidade do antigo regime (despotismo do cargo) com a do novo regime burguês (individualismo possessivo). tornar-se áspero e inclusive feroz, mas os traços se suavizarão e restará apenas o necessário: a força e a energia. Em lugar dessas formas hipócritas, dessa doçura insossa e falsa, dessa cortesia de modos que mostrava por fora o que não sentia no fundo da alma, teremos uma generosidade real, uma bondade franca que nos tornará s6lida e verdadeiramente amáveis..

Mathiez ${ }^{28}$ foi o historiador que mais claramente destacou a revolução moral que se desenvolveu durante a revolução francesa; e o político mais comprometido com a mesma, Robespierre. Se interpretarmos todas as atitudes, discursos e ações de Robespierre como um afã para condicionar a política através de uma determinada moral, entenderemos o que para muitos historiadores não passa da fenomenologia de uma ditadura como o esforço de superar o jogo político segundo o critério de uma revolução moral. Isso significa que a perseguição robespierrista contra hebertistas, dantonistas, enragés e outros, além do girondismo definido pelo próprio Robespierre, pode ser perfeitamente entendida como perseguição à imoralidade aristocrática, à imoralidade demagógica das massas, à imoralidade parlamentar das elites e suas lutas recíprocas, à imoralidade individualista da burguesia em nome da liberdade... De toda a imoralidade do antigo regime, da nova burguesia e de suas combinações. Entendendo-se com esta "imoralidade" aquelas intenções e práticas que valendo-se dos aspectos formais da política resultam na erosão dos próprios fundamentos da política estabelecida. Na Revolução se trata da erosão da Constituição, dos direitos humanos e da unidade e subsistência da nação francesa.

O condicionamento moral que Robespierre preconizava consiste numa disciplina da produção e do comércio para sustentar a nação, disciplina que não deve atentar contra a propriedade nem contra os incentivos à produção, mas que deve obrigar a fornecer eficazmente os bens, levando em conta sobretudo as situações criadas pela guerra e as ameaças que esta representa; uma vigilância incessante contra as tentações elitistas do poder, normalmente promovidas pelos aristocratas e aristocratizantes, bem como uma luta contínua contra as maquinações e os compromissos de elite dotados de força política nacional, uma repressão das iniciativas radicais que, embora fundamentadas, tendem à desautorização

${ }^{28}$ MATHIEZ, Albert, Contributions à l'histoire religieuse de la Révolution Française, Paris, 1907. 
do governo revolucionário e à desorganização que beneficia o inimigo; e um sentido generalizado do dever cívico para compensar todas as deficiências que são normais no exercício formal da política e da economia. Nesta última direção, Robespierre associa, para seu maior vigor, o condicionamento moral à fé no Ser Supremo.

Mably, mais do que Rousseau ou outros filósofos críticos do enciclopedismo, do materialismo e do ceticismo, é o ideólogo mais próximo ao deísmo tal como Robespierre tentará reformulá-lo, para não dizer que é sua fonte exclusiva de inspiração, assim como para a maioria dos convencionais, mais preocupados com a sistemática ideológica do jacobinismo. Em 1794-95 foram publicados os Príncipes de Mahly sur la nfcessitf de la Religion et d'un Culte Public (Princípios de Mably sobre a necessidade da Religião e de um culto público). Trata-se de trechos do Tratado de Legislação de 1776. Seu editor, o deputado Royer, quer demonstrar a maior importância desses textos em relação aos de vários convencionais sobre o mesmo tema:

Com que confiança não vamos beber de tal fonte! As liç̃os de Mably valem sem dúvida mais que as de Manuel, Chaumette, Robespierre e muitos outros. Quão pequenos se tomam esses grandes homens quando comparados àquele! $!^{29}$

Pinçamos os parágrafos mais significativos dessa reedição de Mably logo depois da queda de Robespierre:

Se à virtude e ao vício estão reservados destinos diferentes numa segunda vida, não é a religião uma garantia maior para a honestidade do que o ateísmo? Por mais insensata que seja, um bom legislador saberá tirar partido dela; mas nada pode esperar do ateísmo.

Mably relaciona magistralmente o hedonismo egoísta ao ateísmo, obsessão do discurso moral de Robespierre:

(referindo-se a uma criança educada no ateísmo)... seu espírito, aguerrido contra esses sentimentos extraordinários que a natureza colocou em nosso coração, acostumar-se-á a essa humanidade indulgente que tudo desculpa e adquirirá essa nobreza de pensamento

${ }^{29}$ Principes de Mably sur la nécessité de la Religion et d'un Culte public (Extraits du Traité de la Légisiation - 1776), Paris, ano III (1794-95). Começo e pp. 12, 20, 21, 28 e 36. que não se assusta com coisa alguma. Aos quinze anos, um jovem ateu terá formação suficiente para não se sentir surpreso ante seus mestres quando estes não estabelecerem diferença alguma entre Catão e Catilina, apreciando-os igualmente.

Eis aqui a doutrina funesta do ateísmo... é nisto que se transforma a moral quando já não reconhece a existência de Deus.

Por toda parte a sabedoria humana acha seus limites, e além desses limites vê apenas um abismo sem fundo, a menos que encontre Deus e a fé dos juramentos. Sem ele flutuaríamos numa eterna incerteza sem ele veríamos continuamente ruir o edifício tão mal assentado da sociedade. Minhas fraquezas, minha força, minhas necessidades, minha felicidade, minhas calamidades, meus temores, minhas incertezas, minhas esperanças, todos os sentimentos que experimento são vozes iguais que me chamam a esse Ser Supremo. Sinto que é o primeiro laço que une os homens; sem ele não haveria confiança entre nós e não poderíamos encontrar repouso no mundo. Deus é o primeiro abonador do pacto que fizemos ao entrar em sociedade, só conto com meus concidadãos a partir da fé dessa garantia. Se a justiça humana me oprime, resta-me um consolo, e minha inocência poderá me fazer feliz em meio às desgraças, pois poderei acusar a estupidez ou a maldade humanas perante o tribunal da sabedoria divina.

Em consonância com isso, Mably prescreve a necessidade de um culto público como celebração social do sentimento de divindade. Sentimento este que deve cimentar - moralizar - a sociedade:

Se nossa alma exerce um grande poder sobre nosso corpo, é igualmente verdade que nosso corpo, por sua vez, exerce um grande poder sobre nossa alma; ${ }^{30}$ devido a essa ação recíproca, a religião que desejo deve elevar-se a ideias espirituais e, ao mesmo tempo, estabelecer um culto e cerimônias corporais que unam os cidadãos entre si mediante atos sensíveis que os disponham a participar de um mesmo espírito e a cumprir com seus deveres mútuos... sufocados pelo peso dos negócios que tolamente criamos, ébrios de prazeres e volúpias, governados, ou melhor, tiranizados por paixões tão injustas como nossa avareza e nossa ambição e, enquanto isto, com a terra

${ }^{30}$ É o tema recorrente de boa parte da filosofia moral iluminista, que tratamos aqui, especialmente em Marat e Cabanis. Condillac é sua origem. 
coberta de uma multidão infinita de homens condenados a ganhar o pão com o suor de seu rosto. Podemos dizer, diante de tudo isto, que somos feitos para erguer-nos metafisicamente ao céu? Podemos prescindir de uma religião que, em horas determinadas e em dias solenes, nos convoque aos templos para refrescar em nossa memória o temor a Deus e o amor aos nossos deveres? Não nos iludamos, vejamos os homens tal como eles são...

Platão disse: que nenhum delito fique sem castigo, caso contrário vereis os cidadãos se familiarizarem pouco a pouco com o mal e por fim violar abertamente as leis mais sagradas e importantes. Mas como castigar a cada um dos delitos? Como persuadir os cidadãos, conhecedores dos estreitos limites da sabedoria humana, de que o culpado jamais escapa ao castigo, a não ser com a consciência de que todos nos encontramos nas mãos e sob o olhar de um Ser Supremo que governa o mundo e cuja justiça recompensa a virtude e castiga o vício? Se esta doutrina abre uma fonte de consolações e prazeres para o homem bom; se a sua alma, ocupada com os seus deveres como algo delicioso os cumpre com zelo e ainda espera disto uma recompensa maior, já desfruta de alguma forma, nesta vida, da felicidade da vida futura. Esta doutrina, é preciso reconhecer, inspira um terror saudável aos maus, refreia-os ou, através do remorso, os leva ao arrependimento.

Dir-vos-ei portanto, como Cícero em seu tratado das leis, que os cidadãos devem estar convencidos de que os Deuses são os donos de tudo, que sua providência preside a tudo, que é a fonte de nossos bens, e de que mantêm a contabilidade exata de todas as nossas ações. Esta é a primeira, a mais importante e a mais necessária de todas as leis, já que se Deus não existe, tampouco existe a moral. De outro modo é impossível oferecer ao homem motivos suficientes para que se convença de que deve obedecer a sua razão e não às suas paixões; e só se comportará de conformidade com a justiça se não puder escapar à vigilância das leis e dos magistrados. ${ }^{31}$

Mably critica o ateísmo de d'Holbach, considerando-o inconsequente: se tudo é de caráter necessário no sentido de uma fatalidade natural, não existindo uma moral livre, nem um poder sobre a matéria, por que os ateus não se lançam com mais segurança aos abismos da maldade e

\footnotetext{
${ }^{31}$ Principes de Mably ..., op. cit., p. 6.
}

do egoísmo? É o que farão os ateus de Sade; mas, segundo Mably, o que a maioria deles faz com seu comportamento virtuoso é prestar uma homenagem do ateísmo ao remorso que só Deus pode inspirar.

Do longo relatório elaborado por Robespierre em nome do Comitê de Salvação Pública "sobre as relações entre as ideias religiosas e morais e os princípios republicanos, e sobre as festas nacionais" pinçaremos os parágrafos mais significativos sobre as razões para um monoteísmo com clara fundamentação moral, sobre suas relações com a política e sobre os esforços e contradições de Robespierre em sua teoria de condicionamento do poder político. Esta última chegará ao extremo de depurar, e até exterminar, todos os motores do poder, toda a ambição dos líderes, toda a energia ideológica das elites, equivalente extremo a uma ditadura persecutória de todo desvio formal (psicológico, moral, estético, filosófico...) do papel estrito da organização política estabelecida. Isso significa que Robespierre, com sua ditadura, tentará purificar a política de vícios que são a razão de ser dos políticos, inclusive dele mesmo. ${ }^{32}$

O mundo moral, muito mais que o mundo físico, está repleto de enigmas e contrastes. A natureza nos diz que o homem nasceu para a liberdade, e a experiência dos séculos nos mostra o homem escravo: seus direitos estão escritos em seu coração; sua humilhação, na história; o gênero humano respeita a virtude de Catão e se submete ao jugo de César; a posteridade honra a virtude de Brutus, mas apenas para a história antiga. Os tempos e as terras são divididos entre o crime e a tirania; a liberdade e a virtude mal sobreviveram alguns instantes em alguns cantos do globo. Esparta brilha como uma centelha na noite eterna...

Entretanto, não digas, Ó Brutus!, que a virtude é um fantasma!; e vós, fundadores da república francesa, guardai-vos de desesperar da humanidade ou de duvidar por um só instante do êxito de vossa grande missão!

O mundo mudou, e ainda deve mudar. Que há em comum entre o que é e o que foi? As nações civilizadas sucederam aos selvagens errantes dos desertos; as messes férteis tomaram o lugar dos antigos bosques que cobriam a terra; outro mundo apareceu além dos limites do

${ }^{32}$ La Décade Philosophique, littéraire et politique, Paris, ano II, p. 177, Le Moniteur Universel, $\mathrm{n}^{\circ} 229$, p. 403. 
mundo conhecido; os mares foram somados ao domínio imenso das terras; o homem conquistou o fogo celeste e conjurou sua ameaça. Comparai a linguagem imperfeita dos hieróglifos aos milagres da imprensa; comparai a viagem dos Argonautas com a viagem de La Peyrouse; avaliai a distância entre as observações astronômicas dos Magos da Ásia e as descobertas de Newton, ou entre o esboço da mão de Dibutado e os quadros de David.

Tudo mudou na ordem física, tudo deve mudar na ordem moral e política; a metade da revolução do mundo já está feita, a outra metade ainda deve se cumprir

A razão do homem ainda se parece à face da terra que habita; uma metade mergulha nas trevas quando a outra se ilumina. Os povos europeus progrediram com assombro no que é chamado de artes e ciências mas, no entanto, permanecem na ignorância das noções básicas de moral pública. Conhecem tudo, com exceção de seus direitos e deveres. De onde vem essa mescla de gênio e estupidez? Vem de que para chegar a ser hábil nas artes, basta seguir as próprias paixões, ao passo que para defender seus direitos e respeitar os dos outros é preciso vencê-las. E há outra razão: é que os reis, que dirigem o destino da terra, não temem nem os grandes geômetras, nem os grandes pintores, nem os grandes poetas e, em troca, temem demais os filósofos rigorosos e os defensores da humanidade.

Entretanto, o gênero humano encontra-se num estado de violência que não pode continuar. A razão humana há um bom tempo vem marchando contra os tronos, a passos lentos e com rodeios consideráveis, porém seguros. O gênio ameaça o despotismo ao mesmo tempo em que parece acariciá-lo; sua defesa não é senão o terror e o hábito e, sobretudo, a defesa proporcionada pela liga dos ricos e de todos os opressores subalternos, que agora se espantam com o caráter todo-poderoso da revolução francesa.

Mas o povo francês parece ter-se adiantado em dois mil anos ao resto da espécie humana, em meio à qual pode chegar a parecer uma espécie diferente. A Europa está ajoelhada diante das sombras dos tiranos que nós castigamos. Na Europa, o trabalhador rural, um artesão, é um animal criado para os prazeres de um nobre; na França, os nobres procuram transformar-se em trabalhadores rurais e em artesãos, e inclusive não chegam a alcançar essa honra.
... vós podeis mostrar ao mundo o novo espetáculo da democracia consolidada num vasto império. Aqueles que, na infância do direito público e no seio da servidão, balbuciaram máximas contra ela, será que podiam prever os prodígios operados de um ano para cá? O que vos resta por fazer será mais difícil do que o já feito? Que políticos vos podem servir de modelo ou preceito? Não é lógico que façais precisamente o contrário do que foi feito antes de vós? A arte de governar foi, até hoje, a arte de enganar e corromper os homens; agora deve ser a de iluminá-los e torná-los melhores.

Há dois tipos de egoísmo: o vil, cruel, o que isola o homem de seus semelhantes, que procura um bem-estar exclusivo comprado com miséria do outro; a seguir, há o generoso, benfeitor, que confunde a própria felicidade com a de todos, que ata nossa glória à da pátria. $\mathrm{O}$ primeiro gera os opressores e os tiranos, o segundo forja os defensores da humanidade. ${ }^{33}$ Sigamos seu saudável ímpeto, prezemos o repouso obtido com gloriosos trabalhos; não temamos a morte que os coroa e assim consolidaremos a felicidade de nossa pátria, e também a nossa.

$\mathrm{O}$ vício e a virtude traçam os destinos da terra: são os dois gênios opostos que a disputam. Tanto um como outro surgem das paixões humanas. Conforme a direção que dá a suas paixões, o homem se eleva aos céus ou afunda em abismos de lama. ${ }^{34} \mathrm{O}$ objetivo de todas as instituições sociais é orientá-las para a justiça, que é ao mesmo tempo a felicidade pública e a felicidade privada.

A única base da sociedade civil é a moral. Todas as associações que nos agridem repousam no crime; aos olhos da verdade, não passam de hordas de selvagens com governo e de bandidos disciplinados. A que se reduz então essa ciência misteriosa da política e da legislação? A introduzir nas leis e na administração as verdades morais relegadas aos livros dos filósofos e a aplicar à conduta dos povos as noções elementares de probidade que cada um se esforça para adotar em sua conduta privada; quer dizer, a empregar tanta habilidade para fazer reinar a justiça como os governos utilizaram para ser injustos com impunidade ou com decência.

${ }^{33}$ Este segundo egoísmo coincide com o amor-próprio não-egoísta tão bem descrito por Leopardi.

${ }^{34}$ Esta doutrina, que faz da liberdade a maior força transcendente, deriva de modo explícito do Discurso sobre a dignidade humana de Pico della Mirandola. 
Observai quantas artimanhas os reis e seus cúmplices usaram para fugir à aplicação desses princípios e para obscurecer todas as noções do que é justo ou injusto. Quem bom senso tinha o pirata que respondeu a Alexandre: 'chamam-me de bandido porque só tenho um navio; e a ti, porque tens uma frota, chamam de conquistador!.' Com que pouca vergonha fazem leis contra o roubo quando estão invadindo e dilapidando a fortuna pública! Em seu nome são condenados os assassinos, ao passo que assassinam milhões de homens com a guerra e a miséria. Sob a monarquia as virtudes de família parecem ridículas e as virtudes públicas são crimes. A única virtude é ser instrumento dócil dos crimes do príncipe; a única honra é ser tão mau quanto ele. Sob a monarquia é permitido amar a própria família, mas não a pátria; é considerado honroso defender os amigos, mas não os oprimidos. A probidade da monarquia respeita todas as propriedades, salvo as do pobre; protege todos os direitos, com exceção dos do povo.

Depois de examinar a psicologia da corrupção monárquica e de criticar o regime político britânico, Robespierre conclui:

... que a imoralidade é a base do despotismo, como a virtude é a da república.

A revolução, que tende a restabelecê-la, é a passagem do reino do crime ao da justiça; isto gera a aliança contínua e esforçada de todos os reis contra nós, e a de todos os conspiradores para a perpetuação dos preconceitos e vícios da monarquia.

A oposição aristocrática à revolução valeu-se do vício e da corrupção, assim como o moderantismo abusava da liberdade democrática para continuar corrompendo e fazer com que a pátria se dispusesse a aceitar o jugo estrangeiro:

A liberdade foi atacada por meio da moderação e da fúria. No choque entre as duas facções aparentemente opostas, mas cujos chefes estavam secretamente unidos, a opinião pública ficava destroçada, a representatividade política aviltada, o povo anulado e a revolução não parecia ser senão um combate ridículo para decidir em mãos de que velhacos ficariam o poder de dilacerar e vender a pátria.

O percurso dos líderes de partido aparentemente mais afastados um do outro foi mais ou menos o mesmo: sua principal característica foi uma profunda hipocrisia.
La Fayette invocava a constituição para fortalecer o poder real; Dumouriez invocava a mesma constituição para proteger a facção girondina contra a Convenção Nacional. No mês de agosto de 1792 , Brissote os girondinos queriam fazer da constituição uma couraça para interceptar o golpe que ameaçava o trono. Em janeiro do ano seguinte, os mesmos conspiradores reivindicavam a soberania do povo para libertar a realeza do opróbrio do patíbulo e para fomentar a guerra civil nas assembleias das seções. Hébert e seus cúmplices reivindicavam a soberania do povo para destruir a Convenção Nacional e aniquilar o governo republicano.

Brissot e os girondinos tinham desejado armar os ricos contra o povo; a facção de Hébert, protegendo a aristocracia, incitava o povo a oprimir-se com suas próprias mãos.

Danton teria sido o mais perigoso dos inimigos da pátria se não fosse também o mais covarde. Comandando, todos os crimes, comprometendo-se com todos os complôs, prometendo aos criminosos a sua proteção, aos patriotas a sua fidelidade; hábil para explicar suas traições com pretextos de bem público, para justificar seus vícios com seus pretensos defeitos, Danton fazia com que seus amigos desculpassem ou inculpassem levemente os conspiradores que consumariam a ruína da república, e então ele a defendia; transigia com Brissot, entendia-se com Ronsin, encorajava Hébert procurava tirar proveito do êxito e do fracasso de qualquer iniciativa acabando por unir-se com todos os inimigos da liberdade e do governo republicano.

Foi sobretudo nesses últimos tempos que se assistiu à horrorosa difusão do sistema que nossos inimigos urdiram para corromper a moral pública. Para assegurar-se o triunfo, erigiram-se em seus mestres; manchariam tudo, confundiriam tudo com uma mescla odiosa da pureza de nossos princípios e a corrupção de seus corações.

Todos os velhacos haviam usurpado uma espécie de sacerdócio político e alienavam na classe dos profanos os fiéis representantes do povo e todos os patriotas. Propor uma ideia justa era arriscado; eles haviam proibido o patriotismo de usar o bom senso; houve um momento em que era proibido opor-se à ruína da pátria, sob pena de passar por mau cidadão: o patriotismo não passava de um disfarce ridículo ou da audácia de declamar contra a Convenção. Graças a essa subversão das ideias revolucionárias, a aristocracia, absolvida de todos os seus crimes, tramava "mui patrioticamente" o massacre dos 
representantes do povo e a ressurreição da realeza. Sustentados com os tesouros da tirania, os conjurados pregavam a pobreza; ávidos de ouro e poder, pregavam a igualdade com uma tal insolência que por força a tomavam odiosa. A liberdade era para eles o crime independente; a revolução, um tráfico; o povo, um instrumento; a pátria, uma presa. Até o menor bem que saía de suas mãos era uma pérfida estratégia para provocar irremediáveis danos. Se às vezes mostravam-se severos, era para adquirir o direito de favorecer os inimigos da liberdade e também o de proscrever seus amigos. Envolvidos em todos os crimes, exigiam a absoluta infalibilidade dos patriotas e a garantia contra todos os caprichos da fortuna, a fim de que ninguém ousasse servir a pátria. Vociferavam contra a agiotagem e compartilhavam com os agiotas a fortuna pública: falavam contra a tirania para melhor servir aos tiranos. Os tiranos da Europa acusavam, através deles, a Convenção Nacional precisamente de tirania. Como não podiam propor ao povo o restabelecimento da monarquia, pretendiam obtê-la destruindo o governo desse povo; como tampouco podiam dizer-lhe que se aliasse com seus inimigos, propunham-lhe que expulsasse seus defensores; e não lhe diziam que depusesse as armas, mas o desalentavam com falsas notícias; minimizavam seus erros e exageravam seus fracassos com uma malignidade culposa.

Erigiram a imoralidade não só num sistema, mas como religião; procuraram apagar todos os sentimentos generosos da natureza com seus exemplos e preceitos. O malvado gostaria que não restasse na terra um único homem de bem, para não encontrar um só acusador e poder respirar em paz. Estes malvados buscaram nos espíritos e nos corações tudo que serve de apoio à moral para arrancá-lo dali, a fim de livrar-se da acusação invisível que a natureza abriga nesses refúgios.

$\mathrm{O}$ que pretendiam aqueles que, em meio às conspirações que nos espreitavam, em meio aos apuros da guerra, quando as tochas da discórdia civil ainda fumegavam, atacaram de repente com violência os cultos religiosos para erigir-se eles mesmos em ardorosos apóstolos do nada e missionários fanáticos do ateísmo? Qual era o objetivo dessa grande operação tramada nas trevas da noite, às escondidas da Convenção Nacional, por curas, estrangeiros e conspiradores? Era o amor à pátria? A pátria já lhes infligira o castigo dos traidores. Era o ódio aos curas? Estes eram seus amigos. Era o horror ao fanatismo? Precisamente este era o único meio para conseguir armas. Era o desejo de apressar o triunfo da razão? No entanto ultrajavam-na incessantemente com absurdas violências e extravagâncias organizadas, tornando-a assim mais odiosa: confinavam-na nos templos para excluí-las da república.

Quem te autorizou da missão de anunciar ao povo que a Divindade não existe, e por que te apaixonas por essa árida doutrina e nunca te apaixonas pela pátria? Que vantagem encontras em persuadir o homem de que uma força cega preside seus destinos e golpeia ao acaso o crime e a virtude; que sua alma não passa de um leve sopro que se esfuma no limiar da tumba?

Será que a ideia de seu nada inspira ao homem sentimentos mais puros e elevados que a de sua imortalidade? Inspira-lhe mais respeito para com seus semelhantes e para consigo mesmo, mais dedicação à pátria, mais audácia para desafiar a tirania, mais desprezo pela morte ou pela volúpia? Vós, que lamentais a morte de um amigo virtuoso, agrada-vos pensar que sua parte mais bela escapou à morte! Vós que chorais sobre o sepulcro de um filho ou de uma esposa, senti-vos consolados por quem vos diz que só resta deles o vil pó? Infelizes que expirais sob os golpes de um assassino, não é vosso último suspiro um clamor à justiça eterna? A inocência no patíbulo faz empalidecer o tirano em seu carro triunfal; teria este influxo se a tumba igualasse o opressor e o oprimido? Desgraçado sofista! Com que direito vens arrancar da inocência o cetro da razão para devolvêlo às mãos do crime, vens lançar um véu fúnebre sobre a natureza, fazer o infortúnio desesperar, dar maior gozo ao crime, entristecer a virtude e degradar a humanidade? Quanto mais dotado é um homem de gênio e sensibilidade, mais se apega às ideias que engrandecem seu ser e elevam seu coração, e a doutrina dos homens de tal têmpera é a doutrina do próprio universo. Como não seriam verdade essas ideias? Não concebo como a natureza teria podido sugerir ao homem ficções mais úteis do que todas as realidades; e se a existência de Deus e a imortalidade da alma não fossem mais do que sonhos, seriam, mesmo assim, a mais bela das ideias do espírito humano.

Quero observar que não se trata aqui de acusar alguma opinião filosófica em particular, nem de negar que tal ou qual filósofo possa 
ser virtuoso, sejam quais forem as suas opiniões, e inclusive apesar delas, por causa de uma natureza feliz ou de uma razão superior. Trata-se apenas de considerar o ateísmo como um fenômeno da nação, vinculado a um sistema de conspiração contra a república.

Porém, o que importa a vós legisladores, as diversas hipóteses com que certos filósofos explicaram os fenômenos da natureza? Podeis abandonar todas essas questões a suas eternas disputas; não é como metafísicos nem como teólogos que deveis tratá-las. Aos olhos do legislador, tudo que é útil ao mundo e bom na prática é a verdade. A ideia do Ser Supremo e da imortalidade da alma é um chamado contínuo à justiça: e assim portanto é social e republicana (aplausos na Convenção). A natureza pôs no homem a sensação do prazer e a dor que o força a fugir dos objetos físicos que lhe são nocivos e procurar os que lhe convêm. A obra-prima da sociedade seria criar nele, para defender a moral, um instinto rápido que, sem o socorro tardio do raciocínio, o levasse a fazer o bem e evitar o mal, já que o raciocínio particular de cada homem, perturbado por suas paixões, muitas vezes não passa de um sofisma que cede ao interesse pessoal, e que a autoridade do homem sempre pode ser atacada pelo amorpróprio do homem. Por isso, para gerar ou substituir esse precioso instinto que se torna necessário ante a insuficiência da autoridade humana, temos o sentimento religioso, que imprime nas almas a ideia de uma sanção dada aos preceitos de moral por uma potência superior ao homem. Por isso, não sei de legislador algum que tenha sido partidário da nacionalização do ateísmo. É certo que os mais sábios dentre eles se permitiram mesclar a verdade a algumas ficções, seja para acender a imaginação dos povos ignorantes, seja para prendê-los mais fortemente a suas instituições. Licurgo e Sólon utilizaram a autoridade dos oráculos, e o próprio Sócrates, para incutir a verdade junto a seus concidadãos, viu-se obrigado a convencê-los de que estava inspirado por uma divindade.

Pois bem, não concluais daí que se tenha de enganar os homens para instruí-los, mas simplesmente que sois felizes por viver num século e num país onde as luzes não vos deixam outra tarefa a não ser a de chamar os homens à natureza e à verdade.

Protegei-os de romper o vínculo sagrado que os une ao autor de seu ser. E suficiente que essa opinião saudável tenha existido por pouco tempo num povo para que seja perigoso destruí-la; já que, estando os motivos dos deveres e as bases da moralidade necessariamente ligados a essa ideia, apagá-la é desmoralizar o povo. Devido ao mesmo princípio, não se deve atacar um culto estabelecido, a não ser com prudência e muita delicadeza, por medo de que uma mudança súbita e violenta pareça um atentado à moral e uma dispensa da honestidade. Aliás, quem for capaz de substituir Deus no sistema da vida social será, a meu ver, um gênio prodigioso; quem, sem tê-lo substituído, só pensar em afastá-lo do espírito dos homens será um prodígio de estupidez ou de perversidade.

O que os conjurados haviam posto no lugar do que destruíam? Nada, a não ser o caos, o vazio e a violência. Desprezavam demais o povo para tentar persuadi-lo; em lugar de esclarecê-lo, queriam irritá-lo, assustá-lo ou depravá-lo.

Se os princípios que até aqui desenvolvi são errôneos, pelo menos só me equivoco em afirmar o que todo mundo já acata. Aprendamos aqui as lições da história. Notai, peço-vos encarecidamente, como os homens que influenciaram o desenrolar dos Estados tomaram partido por um ou outro dos sistemas opostos segundo seu caráter pessoal, ou segundo a natureza de seus desígnios políticos. Contemplai com que profunda arte César, advogando em defesa dos cúmplices de Catilina no senado romano, perde-se numa digressão contra o dogma da imortalidade da alma porque estas ideias lhe parecem capazes de apagar no coração dos juízes a energia da virtude, e porque a causa do crime lhe parece vinculada à do ateísmo. Cícero, ao contrário, invocava contra os traidores a espada das leis e o raio fulminante dos deuses. Sócrates morreu conversando com seus amigos sobre a imortalidade da alma. Leônidas nas Termópilas, jantando com os companheiros de armas, no momento de tomar a decisão mais heroica que jamais a virtude humana tenha podido imaginar, convidou-os para outro banquete no dia seguinte, na nova vida. Quão longe estão S6crates de Chaumette e Leônidas do Pere Duchesne! (aplausos) Um grande homem, um verdadeiro herói estima demasiado a si mesmo para que a ideia de seu desaparecimento lhe baste. Um homem mau, desprezível a seus próprios olhos, horrível aos dos outros, este sim pode sentir que a natureza não lhe pode dar presente melhor que o nada ${ }^{35}$ (aplausos).

${ }^{35}$ Robespierre distingue entre as possibilidades de uma doutrina e os usos que ela recebe em determinados contextos. Assim nos esclarece o seu conceito de corrupção: o aproveitamento e a confusão de ideias úteis e boas em práticas nocivas. 
Catão não duvidou nem um instante entre Epícuro e Zenão. Brutus e os ilustres conjurados que compartilharam seus perigos e sua glória também pertenciam à sublime seita dos estóicos, que tão elevadas ideias teve da dignidade do homem, que tão longe levou o entusiasmo pela virtude e mostrou tanto heroísmo. O estoicismo gerou rivais de Brutus e Catão até nos odiosos séculos que se seguiram à perda da liberdade romana. $\mathrm{O}$ estoicismo salvou a honra da natureza humana, degradada pelos vícios dos sucessores de César e, sobretudo pela paciência dos povos. A seita epicurista reivindicava para si todos os perversos que oprimiram sua pátria e todos os covardes que deixaram que fosse oprimida. Contudo, embora o filósofo que leva seu nome não fosse pessoalmente um homem desprezível, os princípios de seu sistema, interpretados pela corrupção, trouxeram consequências tão funestas que a própria antiguidade utilizou a expressão rebanho de Epícuro como infamante; e já que em todos os tempos o coração humano no fundo não muda e o mesmo instinto e o mesmo sistema político faz os homens andarem no mesmo passo, será fácil aplicar essas observações históricas ao momento atual, e também ao imediatamente anterior à nossa revolução... Os homens de letras famosos, em virtude de sua influência sobre a opinião pública, começaram a influenciar também os negócios políticos. Os mais ambiciosos haviam formado, desde então, uma espécie de coligação que aumentava sua importância; pareciam estar divididos em duas seitas, uma delas encarregada de defender estupidamente o clero e o despotismo. A mais poderosa e ilustre era a que se tomou conhecida com o nome de enciclopedista; junto com alguns homens dignos de estima, envolvia grande número de charlatães ambiciosos; muitos de seus chefes haviam chegado a ser personagens importantes no Estado. Quem ignorasse sua influência e sua política não teria uma ideia adequada do prefácio de nossa revolução. Em matéria de política, esta seita sempre permaneceu abaixo dos direitos do povo; em matéria de moral, foi além da destruição dos preconceitos religiosos. Seus corifeus às vezes clamavam contra o despotismo e recebiam pensões dos déspotas; às vezes escreviam livros contra a corte, às vezes dedicatórias aos reis, discursos para os cortesãos e madrigais para as cortesãs; eram tão soberbos em seus escritos como rasteiros nas antecâmaras. Essa seita propagou com muito zelo a opinião do materialismo, que prevaleceu entre os grandes e cultos. Em grande medida lhe é devida essa espécie de filosofia prática que, fazendo do egoísmo um sistema, considera a sociedade humana uma guerra de astúcia, o êxito como sinônimo do justo, a honestidade como de bom tom ou de bem-estar, o mundo como patrimônio dos egoístas habilidosos. Já disse que seus corifeus eram ambiciosos; as agitações que anunciavam uma grande mudança na ordem política das coisas fizeram-nos adotar novas perspectivas. Muitos deles tinham relações íntimas com a casa de Orleans, e a Constituição inglesa era para eles a obra-prima da política e a máxima expressão do bem social.

Entre os que se distinguiram na carreira das letras e da filosofia na época à qual me refiro, um homem, em virtude da grandeza de seu caráter e da elevação de sua alma, mostrou-se digno do ministério de preceptor do gênero humano. Atacou com franqueza a tirania, falou com entusiasmo da Divindade; sua eloquência viril e honesta traçou com a vividez das chamas os encantos da virtude, defendendo esses dogmas consoladores que a razão concede como apoio ao coração humano; a pureza de sua doutrina, extraída da natureza e do ódio profundo ao vício, tanto como de seu desprezo imbatível em relação aos sofistas intrigantes que usurpavam o nome de filósofos, atraíram sobre ele o ódio e a perseguição de seus rivais e de seus falsos amigos. Ah, se tivesse sido testemunha desta revolução da qual foi precursor e que o levou ao Panteão, quem pode duvidar de que sua alma generosa teria abraçado com arrebatamento a causa da justiça e da igualdade? Mas o que fizeram por ela seus covardes adversários? Combateram a revolução desde o momento em que temeram estar ela elevando o povo acima de todas as vaidades particulares; uns empregaram sua inteligência para adulterar os princípios republicanos e corromper a opinião pública; prostituíram-se as facções e sobretudo o partido de Orleans; outros fecharam-se numa covarde neutralidade. Os homens de letras, de maneira geral, desonraram-se nesta revolução e, para vergonha eterna do espírito, a razão do povo teve que recompensá-la apenas com seu esforço.

Homens vãos e medíocres, corai de vergonha se vos for possível; os prodígios que imortalizaram essa época da história humana foram operados sem vós e apesar de vós; o bom senso sem intriga e o gênio sem instrução ergueram a França a essa altura que espanta vossa baixeza e esmaga vossa nulidade. Um artesão mostrou-se mais hábi no conhecimento dos direitos do homem do que um escritor, que já quase republicano em 1788, mais tarde, em 1793, defendia a causa dos reis com toda a estupidez de que era capaz. Um lavrador difundia a luz da filosofia no campo quando o acadêmico Condorcet, que fora 
um grande geômetra, segundo os literatos, e um grande literato, segundo os geômetras, depois conspirador tímido, desprezado por todos os partidos, trabalhava sem cessar para apagar essa luz com a pérfida confusão de suas rapsódias mercenárias.

Sem dúvida vos sentistes escandalizados pela ternura com a qual tantos homens que traíram sua pátria acariciaram as sinistras opiniões que me achais combatendo. Que relações tão curiosas ainda podem ser apresentadas aos vossos espíritos! Ouvimos - quem teria acreditado nesta excessiva falta de vergonha? -, ouvimos numa Sociedade Popular o traidor Guadet denunciar um cidadão por ter este pronunciado o nome da Providência! Pouco tempo depois, ouvimos Hébert acusar outro por ter escrito contra o ateísmo. Não foram Vergniaud e Gensonné que, em vossa presença, em vossa tribuna, peroraram acaloradamente para que fosse apagado do preâmbulo da Constituição o nome do Ser Supremo que havíeis escrito? Danton, cujo sistema era aviltar o que pode elevar a alma; que era frio e mudo nos perigos mais graves que ameaçavam a liberdade, falou depois deles com muita veemência e a favor da mesma opinião. De onde procede esse singular acordo de princípios entre homens aparentemente divididos? A que atribuí-lo? Simplesmente ao cuidado que tinham os desertores da causa do povo em procurar encobrir sua deserção com uma afetação de zelo contra o que chamavam de preconceitos religiosos, como se quisessem compensar sua indulgência para com a aristocracia e a tirania por meio da guerra que declaravam à Divindade.

Não, o comportamento desses personagens artificiosos dependia sem dúvida de opiniões políticas mais profundas; davam-se conta de que para destruir a liberdade era preciso favorecer por todos os meios tudo que tende a justificar o egoísmo, a endurecer o coração e a apagar a ideia de beleza moral, a única regra válida para a razão pública julgar os defensores e os inimigos da humanidade. Abraçavam com ardor um sistema que, confundindo o destino dos bons e o dos maus, não deixa entre eles outra diferença além dos incertos favores da fortuna, nem outra arbitragem além do direito do mais forte ou mais astuto.

Vós perseguis um objetivo totalmente diferente; devereis, portanto, seguir uma política contrária. Mas não existe o risco de despertar o fanatismo e dar vantagem à aristocracia? Não, se adotarmos o partido que a sabedoria indica, evitando esse obstáculo.
Fanáticos, não espereis nada de nós. Conclamar os homens ao culto puro do Ser Supremo é acertar um golpe mortal no fanatismo. Todas as ficções desaparecem ante a verdade e todas as loucuras caem ante a razão. Sem violência, sem perseguição, todas as seitas devem unirse na religião universal da natureza (aplausos). Aconselhamos-vos, pois, a manter os princípios que até agora haveis observado. Que a liberdade de culto seja respeitada para o próprio triunfo da razão, mas que não altere a ordem pública e não seja meio de conspiração; se a malevolência contrarrevolucionária se esconder sob esse pretexto, deveis reprimir e repousai, de resto, no poder dos princípios e na própria força das coisas. ${ }^{36}$

Curas ambiciosos, não espereis que trabalhemos para restabelecer vosso império; tal iniciativa estaria inclusive além de nosso poder (aplausos). Vós mesmos vos suicidastes, e não se pode voltar à vida moral, como tampouco se pode voltar à existência física. Ademais, o que existe entre Deus e os sacerdotes? Os curas são para a moral o que os charlatães são para a medicina (mais aplausos). Quão diferente é o Deus da natureza do Deus dos curas (os aplausos continuam)! Não conheço nada tão parecido ao ateísmo como as religiões que os curas fizeram: de tanto desfigurar o Ser Supremo, também o aniquilaram neles mesmos; transformaram-no numa bola de fogo, ou num boi, numa árvore, num homem ou num rei. Os curas criaram Deus à sua imagem; fizeram-no ciumento, caprichoso, ávido, cruel, implacável, trataram-no como em outro tempo os descendentes de Clóvis trataram os dignitários do palácio, para reinar em seu nome e ocupar seu lugar; relegaram Deus ao céu como a um palácio, e só o chamaram à terra para pedir em proveito próprio os dízimos, as riquezas, as honras, os prazeres e o poder (vivos aplausos). O verdadeiro sacerdote do Ser Supremo é a natureza, seu templo, o universo; seu culto, a virtude e suas festas, a alegria de um grande povo reunido sob seu olhar para estreitar os laços doces da fraternidade universal e para prestar-lhe a homenagem dos corações sensíveis e puros.

${ }^{36}$ Robespierre institui o culto ao Ser Supremo como ponto culminante dos demais cultos,
não como sua negação necessária. É neste sentido que defende a tolerância e a prática preeminente do que considera a verdadeira religião. 
Curas, com que títulos demonstrastes vossa missão? Fostes mais justos, mais modestos, mais amigos da verdade do que os demais homens? Haveis amado a igualdade, defendido os direitos dos povos, lamentado o despotismo e abatido a tirania? Fostes vós que dissestes aos reis: 'Sois as imagens de Deus na terra; Dele vos vem o poder', e os reis vos responderam: 'sim, sois verdadeiramente os enviados de Deus; unamo-nos para repartir os despojos e as adorações dos mortais.' O cetro e o turíbulo conspiraram para desonrar o céu e usurpar a terra (aplausos)

Deixemos os curas e voltemos à Divindade (aplausos). Vinculemos a moral a bases eternas e sagradas; inspiremos ao homem esse respeito religioso pelo homem, esse profundo sentimento dos deveres, que é a única garantia do bem social; nutramo-lo com todas as nossas instituições. Que a educação pública dirija-se preferencialmente para esse objetivo; sem dúvida lhe imprimireis um grande caráter, análogo à virtude de nosso governo e à grandeza dos destinos de nossa república. Sentireis a necessidade de torná-la comum e igual para todos os franceses. Já não se trata de educar senhores, e sim cidadãos; só a pátria tem o direito de educar seus filhos, e não pode ceder essa obrigação ao orgulho das famílias nem aos preconceitos dos particulares, eternos alimentos da aristocracia e de um federalismo localista que apequena os espíritos, pois os isola e destrói a igualdade e os fundamentos da ordem social. Mas esse grande objetivo não pertence à discussão de agora.

Entretanto, há uma espécie de instituição que deve ser considerada como parte essencial da educação pública e que pertence necessariamente ao tema deste relatório. Refiro-me às festividades públicas.

Reuni os homens e os transformareis em melhores, já que os homens, uma vez juntos, procurarão se apreciar, e só se apreciarão através das coisas que os tornam dignos de estima; dai a sua reunião um grande motivo moral e político e o amor às coisas honestas entrará com prazer em todos os corações, já que os homens sabem descobrir-se, encontrar-se, com prazer.

O homem é o maior objeto da natureza; e o espetáculo cuja magnificência supera todos os demais é o de um grande povo reunido. Jamais se falou sem emoção das festas nacionais da antiga Grécia, embora nelas fossem exibidas a força do corpo, a habilidade, o talento dos poetas e oradores e nada mais. Mas toda a Grécia comparecia; via-se um espetáculo maior do que os jogos, o espetáculo constituído pelos próprios espectadores; era o povo vencedor da Ásia, cujas virtudes republicanas o haviam elevado acima da humanidade. Via-se os grandes homens que tinham salvo e instruído a pátria; os pais mostravam aos seus filhos Milcíades, Aristides, Epaminondas e Timoleon, cuja mera presença era uma lição viva de magnanimidade, justiça e patriotismo (aplausos).

Como seria fácil para o povo francês proporcionar às suas festas uma finalidade mais universal e um caráter de maior grandeza! Um sistema de festas nacionais bem entendido seria ao mesmo tempo o mais doce vínculo de fraternidade e o meio mais potente de regeneração.

Criai festas gerais e mais solenes para toda a república; criai festas particulares e locais que sirvam de dias de repouso e substituam as que foram suprimidas pelas circunstâncias.

Que todas tendam a despertar os sentimentos generosos que constituem o encanto e o adorno da vida humana, o entusiasmo pela liberdade, o amor à pátria, o respeito às leis. Que nelas a memória dos tiranos e dos traidores seja condenada à execração; que a dos heróis da liberdade e dos benfeitores da humanidade receba o justo tributo do reconhecimento público; que também extraiam seus motivos e seus nomes dos acontecimentos imortais de nossa revolução e dos objetos mais sagrados e mais caros ao coração humano e que sejam embelezadas e distinguidas por emblemas equivalentes a seu objetivo particular. Convidemos para nossas festas a natureza e todas as virtudes; que todas sejam celebradas sob os auspícios do Ser Supremo, que todas as festas lhe sejam consagradas, que comecem e acabem com uma homenagem ao seu poder e à liberdade.

Darás teu sagrado nome a uma das festas mais belas, ó tu, filha da natureza! Mãe da glória e da felicidade! Tu, única legítima soberana do mundo, destronada pelo crime; tu a quem o povo francês devolveu o império e a quem dás em troca uma pátria e bons costumes, augusta Liberdade! Tu Rutilharás nossos sacrifícios com tua companheira imortal, a doce e santa Igualdade (aplausos). Celebraremos humanidade, a humanidade aviltada e pisoteada pelos inimigos da república francesa. Será belíssimo o dia em que realizarmos a festa do gênero humano; será o ágape fraterno e sagrado ao qual, no bojo da vitória, o povo francês convidará a família imensa cujos direitos e 
honra defende solitário! Celebremos também a todos os grandes homens, de qualquer tempo e país, que tiverem libertado sua pátria do jugo dos tiranos ou fundamentado a liberdade com sábias leis. Não sereis de forma alguma esquecidos, ilustres mártires da república francesa! Não sereis de forma alguma esquecidos, heróis que morrestes combatendo por ela! Quem poderia esquecer os heróis de minha pátria! A França lhes deve sua liberdade, o universo lhes deverá a dele! Que o universo em breve celebre sua glória desfrutando de suas boas obras! Quantos traços heroicos são encontrados na miríade de grandes façanhas que a liberdade teve por bem prodigar entre nós! Quantos nomes dignos de serem inscritos nos faustos da história permanecem enterrados na escuridão! Almas desconhecidas e reverenciadas, se escapais à celebridade, ao menos não escapareis ao nosso terno reconhecimento!

Que tremam todos os tiranos armados contra a liberdade, se é que no futuro ainda existirão! Que tremam no dia em que os franceses acorrerem a vossas tumbas e jurarem vos imitar! Jovens franceses, ouvis o imortal Bara que, de dentro do Panteão, vos chama à glória? Vinde espargir flores sobre sua tumba sagrada (Jovens Alunos da Pátria que se encontram na assembleia exclamam com o mais vivo entusiasmo: viva a república!). Bara, filho heroico!, sustentavas tua mãe e morreste pela pátria! Bara, já recebeste o prêmio por teu heroísmo: a pátria adotou tua mãe; a pátria, sufocando as facções criminosas, vai elevar-se triunfante acima das ruínas dos vícios e dos tronos. Oh, Bara! Não encontraste um modelo na antiguidade, mas encontraste entre nós os êmulos de tua virtude! ${ }^{37}$

Por que fatalidade ou ingratidão caiu no esquecimento um herói ainda mais jovem e digno das homenagens da posteridade? Os marselheses rebelados, reunidos à margem do rio Durance, preparavam-se para atravessá-lo com o intuito de degolar os patriotas fracos e indefesos dessas desditosas comarcas. Do outro lado do rio, uma reduzida tropa de republicanos não via outro recurso para impedir o avanço do inimigo senão cortar o cabo da embarcação que iam utilizar para atravessar o rio; mas tentar tal iniciativa na presença dos numerosos batalhões que cobriam a outra margem, e ao alcance de seus fuzis, parecia uma tarefa quimérica aos mais ousados. De

${ }^{37}$ A antiguidade como modelo a imitar e ultrapassar. Como referência de perfeição, mas de certo modo historicamente superável. repente, uma criança de onze anos se apodera de um machado, corre até a beira do rio e atinge o cabo com toda sua força (ouvem-se os mais vivos aplausos). Vários disparos de mosquetes o alvejam, ferindo-o; ainda ergue o machado e finalmente o cabo se parte. A criança cai mortalmente ferida; exclama:

"Que me importa! Morro, mas meu país está salvo!"; caiu, está morta... (aplausos reiterados), o sul da França foi salvo. Respeitável criança!, que a pátria se orgulhe de ter-te dado à luz! Com que orgulho Grécia e Roma teriam homenageado tua memória se tivessem gerado um homem como tu!

Cidadãos, levemos suas cinzas com pompa para o templo da glória! Que a república de luto as cubra com o orvalho de suas amargas lágrimas! Mas não, não choremos mais; imitemo-lo, vinguemo-lo com a desolação de todos os inimigos de nossa república.

Todas as virtudes disputam o direito de presidir as nossas festas. Instituamos a festa da Glória, não da que assola e oprime o mundo, mas da que o liberta, ilumina e consola, da que, depois da pátria, é o primeiro ídolo dos corações generosos. Instituamos uma festa mais comovedora, a festa da Desgraça. Os escravos adoram a fortuna e o poder; nós honramos a desgraça, a desgraça que a humanidade não pode exilar totalmente de nossa terra, mas que pode consolar e alivia com respeito. ${ }^{38} \mathrm{Tu}$ também obterás esta homenagem, ó tu que em outro tempo unias os heróis e os sábios, tu que multiplicas as forças dos amigos da pátria, e que os maus, aliados pelo crime, só conheceram de ti um simulacro impostor, divina Amizade!

Por que não prestaríamos a mesma homenagem ao pudico e generoso amor, ao amor conjugal, à ternura paterna, à piedade filial? Nossas festas sem dúvida não perderão com isto nem seu encanto nem seu brilho. Nelas estareis vós, bravos defensores da pátria a quem servem de condecoração gloriosas cicatrizes, e vós, veneráveis anciãos que a ventura preparada para vossa posteridade deve consolar de uma longa vida transcorrida sob o despotismo, e também vós, ternos Alunos da Pátria que cresceis para estender sua glória e para colher o fruto de nossos trabalhos!

${ }^{38}$ Este é o ponto-chave da argumentação teísta de Robespierre condicionada pela moral; a desgraça não pode chegar a ser totalmente erradicada da face da terra. 
Estareis vós, jovens cidadãs a quem a vitória fará vossos irmãos e amantes dignos de vós; estareis vós, mães de família cujos filhos e esposos erguem troféus à república com os despojosos dos tronos (aplausos). Oh, mulheres francesas, amai a liberdade conquistada com o preço de seu sangue, servi-vos de vossa influência para estender a da virtude republicana! Oh, mulheres francesas, sois dignas do amor e do respeito da terra toda! Que podeis invejar às mulheres de Esparta? Como elas, destes a vida a heróis; como elas, vos entregastes, com sublime abandono, à pátria (aplausos).

Maldição aos que buscam a extinção do entusiasmo sublime e desse instinto moral do povo que é o princípio de todas as grandes ações; maldição aos que se valem de doutrinas desoladoras para esses propósitos! A vós, representantes do povo, vos incumbe levar ao triunfo as verdades que expusemos; desafiai sem medo os insensatos clamores da ignorância presunçosa ou da perversidade hipócrita. Qual é a depravação que dizem que nos rodeia, depois da coragem que necessitamos para proclamar essas verdades? Será que a posteridade poderá acreditar que as facções vencidas haviam pretendido nos acusar de moderantismo e de aristocracia por termos invocado a ideia da Divindade e da moral? Acreditará que tenha existido neste recinto a ousadia de culpar-nos pelo retrocesso da razão humana depois de um avanço de séculos? Porque os monstros que afiavam contra vós seus punhais sacrílegos invocavam a Razão! Todos os que defendiam vossa dignidade e vossos princípios também deviam ser objeto de sua fúria. Não nos assombremos por todos os malfeitores aliados contra nós terem-nos preparado a cicuta; mas antes de bebê-la salvaremos a pátria! $!^{39}$ A nave que traz a fortuna da república não está destinada ao naufrágio; navega sob vossos auspícios, e as tempestades a ela se curvarão com respeito (mais aplausos).

O discurso de Robespierre terminou propondo o seguinte decreto:

Art. I. O povo francês reconhece a existência do Ser Supremo e a imortalidade da alma.

II. Reconhece que o culto digno do Ser Supremo é a prática dos deveres do homem.

${ }^{39}$ Esta frase foi, ao que parece, a que David incluiu no final de seu discurso para atestar sua solidariedade a Robespierre
III. No rol desses deveres figura detestar a má-fé e a tirania, castigar os tiranos e os traidores, socorrer os desgraçados, respeitar os fracos, defender os oprimidos, fazer aos outros todo o bem possível e não ser injusto com ninguém.

IV. Serão instituídas festas para aproximar o homem do pensamento da Divindade e da dignidade de seu ser.

V. Tirarão seus nomes dos fatos gloriosos de nossa revolução, das virtudes mais prezadas e úteis ao homem e dos grandes dons da natureza.

VI. A república francesa celebrará todos os anos as festas de 14 de julho de 1789 (queda da Bastilha), 10 de agosto de 1792 (ataque às Tulherias e suspensão da monarquia), 21 de janeiro de 1793 (execução do rei) e 31 de maio de 1793 (sublevação antigirondina).

VII. Celebrará nos dias decadários as festas das seguintes invocações: ao Ser Supremo, à natureza; ao gênero humano; ao povo francês; aos benfeitores da humanidade; aos mártires da liberdade; à liberdade e à igualdade; à república; à liberdade do mundo; ao amor à pátria; ao ódio aos tiranos e traidores; à verdade; à justiça; ao pudor; à glória e à imortalidade; à amizade; à frugalidade; à coragem; à boafé; ao heroísmo; ao desprendimento; ao estoicismo; ao amor; ao amor conjugal; ao amor paterno; à ternura materna; à piedade filial; à infância; à juventude; à idade viril; à velhice; à desgraça; à agricultura; à indústria; aos nossos antepassados; à posteridade; à felicidade.

VIII. Os comitês de salvação pública e de instrução pública são os encarregados de elaborar um plano de organização dessas festas.

IX. A convenção Nacional conclama todos os talentos dignos de servir a causa da humanidade a terem a honra de colaborar com sua celebração com hinos e cânticos cívicos e com todos os meios que possam contribuir para seu embelezamento e utilidade.

X. O comitê de salvação pública distinguirá as obras que lhe parecerem mais adequadas a esses objetivos e recompensará seus autores.

XI. A liberdade de culto é mantida, conforme o decreto de 18 do frimário. 
XII. Toda reunião aristocrática e contrária à ordem pública será reprimida.

XIII. Em caso de desordens causadas ou ocasionadas por qualquer culto, os que as tiverem excitado com pregações fanáticas ou com insinuações contrarrevolucionárias e os que as tiverem provocado com violências injustas e gratuitas serão igualmente castigados de acordo com o rigor das leis.

XIV. Será feito um relatório pormenorizado sobre as várias disposições que constam deste decreto.

XV. Será celebrada no dia 2 do prairial próximo uma festa em honra ao Ser Supremo. David se encarregará de apresentar seu plano à Convenção Nacional.

Couthon pediu que, além da publicação habitual do relatório, fosse feita uma tiragem destinada a ser afixada nos muros das cidades e aldeias, pedindo também a sua tradução para diversas línguas, já que "a moral da representação nacional foi caluniada entre os povos estrangeiros”.

A referência ao descondicionamento moral do capitalismo é o sinal do Termidor, da queda de Robespierre, embora todo o resto experimente poucas mudanças, e é neste sentido que se pode falar de reação termidoriana: "Pronunciai solenemente que todo cidadão que emprega seus dias utilmente, dedicando-se aos trabalhos da agricultura, das ciências, das artes, do comércio, que constrói ou mantém fábrica, manufatura, não pode ser perturbado nem tratado como suspeito". Dizendo isto, os comitês termidorianos de salvação pública, segurança geral e legislação referiam-se "ao comércio que Robespierre queria aniquilar". 40

$\mathrm{O}$ esforço de Robespierre no intuito de destruir ou conter a imoralidade do sistema burguês, condicionar o capitalismo à virtude, resume-se, depois do Termidor, em caricatura de uma obsessão pessoal. $\mathrm{O}$ moralismo robespierrista transforma-se em pura tirania sobre a opinião pública; a sua oposição ao elitismo em inveja do talento; o seu respeito para com a essência do capitalismo; em oportunismo; a sua propagação da virtude pública em capricho de sua ditadura; a sua iniciativa purificadora

${ }^{40}$ La Décade..., op. cit., t. II, p. 59. em arrogância aristocrática; e o seu sacrifício pessoal em insensibilidade. Assim o retrata Dubois-Crancé após a queda ${ }^{41}$ :

Tentarei apresentar-vos um esboço do caráter de Robespierre... Para começar, sempre com a palavra povo na boca, esse monstro habilidoso não se ocupou de outra coisa durante os cinco últimos anos além do estabelecimento de seu império absoluto na opinião pública. Inimigo mortal de todos os talentos, enciumado ao extremo de todas as reputações, aproveitou com habilidade os vícios de uns e as fraquezas de outros para ultrapassar a todos... Sempre o mesmo, que dizer, sempre igualmente orgulhoso, ciumento, irascível, atribuía exclusivamente a si próprio a honra pela queda de todas as facções, e fazia-se chamar o Incorruptível.

Bom povo! Não te davas conta de que Robespierre era o mais arrogante dos homens e, por conseguinte, o mais aristocrata.

Desprezando tudo, inclusive os amigos, mostrava-se sempre ao povo como Brutus imolando seus filhos à liberdade; mas era Nero sacrificando Sêneca e, como Calígula, não teria tardado em querer que o povo francês adorasse seu cavalo.

Politicamente, Dubois-Crancé conclui que a única fórmula observada por Robespierre foi dividir para reinar. Sua oposição às ameaças elitistas, demagógicas, desorganizativas e polarizadoras do novo capitalismo democrático esfumaram-se em desvario de um tirano. O terror público de seu regime foi substituído pela nova miséria pública e privada que assegurava o prazer da "jeunesse dorée” da época do auge do Diretório.

Louis Blanc interpreta assim a política religiosa de Robespierre, o "filósofo das tristezas divinas" "42.

Ainda não chegara o tempo em que seria possível conseguir a regeneração da sociedade com a mera força da solidariedade humana Robespierre via diante de si uma multidão de fracos que era preciso proteger, de desgraçados que era preciso salvar do abandono em que se encontravam, um povo que precisava ser livrado do flagelo da miséria e da ignorância. Um poder justo e sempre ativo era o único que Robespierre acreditava poder intervir nesse estado da sociedade.

\footnotetext{
${ }^{41}$ AULARO, F.-A., La Société des Jacobins, op. cit., t. 6, p. 316 (3-VIII-1794).
}

${ }^{42}$ BLANC, Louis, Histoire de la Révolution Française, Paris, 1866 (?), p. 648. 
Se tomou-se teísta, não foi como Voltaire pela necessidade de explicar com mais ou menos lógica a criação, mas pela necessidade de dispor de um protetor para os fracos e os oprimidos, protetor que cedo ou tarde restabeleceria o equilíbrio e cuja justiça devia ser considerada uma garantia contra a eternidade da opressão.

\section{A festa do Ser Supremo}

O Ser Supremo coloca-se rapidamente como principal tema do devocionário da Razão e da Liberdade. Seu estabelecimento evoca o grande arquiteto do culto maçônico, o Deus distante do deísmo filosófico, o Deus providencial ou vingador do deísmo patriótico e o Ser necessário à esperança e ao temor humano. Ao mesmo tempo, o catolicismo continua influenciando, com seus hábitos e liturgias, a representação teísta. Essa influência chega a ser tão poderosa que ou os novos deísmos devem ser interpretados como uma vitória ante o catolicismo mas com o uso de muitos meios similares, ou como uma imitação da poderosa religião católica, sem chegar a conseguir seu enraizamento popular.

Por um lado, o deísmo patriótico procura conquistar independência:

Deus benfeitor a quem adoro! Ser incompreensível, cujos desígnios ocultos de tua providência escolheram a Razão como gênio tutelar da França; recebe nossas preces! São-te oferecidas com candura. Tu, que criaste nossas almas, não gostarias que fossem manchadas pelo mais horrível dos vícios, a ingratidão. Recebei, pois, com bondade, o juramento solene que teus filhos, doce esperança da pátria, fazem a ti com a minha voz, de viver para a Liberdade, a Razão e a Igualdade; acostuma logo os nossos olhos aos raios de tua glória; acrescenta a esses dons a prudência e a coragem necessárias a republicanos virtuosos que só querem crescer (esta prece devia ser recitada por uma criança) para defender a obra imortal de seus pais, a República una e indivisível dos franceses. Viva a República!

${ }^{1}$ CHÉNIER, DUSAUSAOIR et alii, Office des Décades ou Discours, Hymnes et Prières en usage dans les Temples de la Raison, Paris, ano II (Decadi, 30 do ventoso).

Numa sátira contrarrevolucionária, a implantação do culto à Liberdade, à Razão e ao Ser Supremo é interpretada como um escárnio infligido ao povo, de forma análoga ao escárnio sofrido por Cristo em sua Paixão:

"Quando os malfeitores se cansaram de flagelá-lo (o povo, com o Terror), o governador Chaumette desceu à sala com o bispo Gobet (Gobel), o père Duchêne (Hébert) e o orador do gênero humano (Cloots) e juntos conduziram o povo à Notre-Dame, fantasiaram-no com uma boina vermelha, um manto cor de sangue e um bastão de peregrino na mão; e prosternaram-se calmamente diante dele, cuspindo-lhe na cara $\mathrm{e}$ chamando-o desdenhosamente de Povo Soberano. 
Por outro lado, porém, a substituição de temas numa fórmula tipicamente católica também é corrente. Podemos observá-la neste Credo republicano, ${ }^{2}$ onde a República substitui a Igreja, a Constituição toma o lugar da Salvação, a Revolução o da Ressurreição, a Liberdade o da Vida eterna...

Creio num Ser Supremo que criou os homens livres e iguais, que os fez para que se amassem, não para que se odiassem; que quer ser honrado com virtudes e não com o fanatismo; e aos olhos de quem o culto mais belo é o da razão e da verdade. Creio que a unidade e a indivisibilidade da República fazem a felicidade do povo; que uma união indissolúvel com a Constituição que aceitou é a única capaz de assegurar-lhe a felicidade, e que o homem, para conservar seus direitos, não deve jamais esquecer os seus deveres.

Creio na destruição próxima de todos os tiranos e rebeldes, na regeneração dos costumes, na propagação de todas as virtudes e no triunfo eterno da Liberdade.

Danton $^{3}$ não esquecia tampouco a referência culminante ao Ser Supremo nas suas propostas de cerimonialização do patriotismo:

Neste momento em que a superstição sucumbe para dar lugar à razão, deveis dotar de centralismo a instrução pública, assim como já fizestes com o governo. Sem dúvida a juventude está sendo instruída nos grandes princípios da razão e da liberdade de maneira difusa, dispersa; mas o povo inteiro deve celebrar as grandes ações que honraram a nossa Revolução. Deve reunir-se num templo vasto, e peço que os mais destacados artistas colaborem com seus projetos para sua edificação; ali, num dia determinado, serão celebrados jogos nacionais. Se a Grécia teve seus jogos olímpicos, a França também solenizará suas sans-culottides. O povo desfrutará de festas nas quais

Então, o sumo sacerdote Robespierre, vendo-o neste estado deplorável, sentiu que suas entranhas se comoviam e teve piedade da alma imortal dos homens. Assim, resolveu colocála sob a proteção do Ser Supremo e reinar em seu lugar enquanto esperava a salvação.

Sob a influência dessa virtuosa ideia, pegou seu belo hábito azul, arrumou os óculos no nariz e, com a ajuda do gotoso Couthon e de dom Nicolas (Restif de La Bretonne), arrastou-o até as Tulherias. E, no balcão, pronunciou seu famoso discurso sobre os incômodos da grandeza...” BONACE, Mathurin, La Passion du peuple, Paris, s.d., p. 11.

${ }_{2}^{2}$ Idem, op. cit.

3 Procès-Verbaux du Comité d'Instruction Publique de la Convention Nationale, 6 do frimário, ano II, Discurso de Danton, p. 37. oferecerá incenso ao Ser Supremo, ao mestre da Natureza, já que não quisemos aniquilar a superstição para implantar o reino do ateísmo...

A celebração da festa do Ser Supremo, que teria lugar em 28 do prairial do ano II (8-VII-1794), foi objeto de consideráveis debates, ordens e contraordens. ${ }^{4}$ De Boissy d'Anglas a Michelet, a festa do Ser Supremo foi a mais criticada da Revolução, entendida como festa da entronização de Robespierre e ponto de inflexão de sua hegemonia. Criticada também, é claro, junto com as festas da Razão, por terem sido consideradas uma pantomima e um endeusamento ridículos de pessoas e símbolos da Revolução. ${ }^{5}$

No entanto, algumas opiniões, inclusive as de alguns antigos girondinos, consideraram a emoção e a espontaneidade da festa muito próprias da revolução e de seus valores. O hino de Desorgues-Gossec parece ter contribuído consideravelmente para causar tal sensação e, ao lado de outros gestos, pôde dotar de mais emoção o momento mais caricatural de toda a festa

O presidente (Robespierre) desceu, seguido de uma comissão de representantes e de comissários das seções, para atear fogo ao colossal relatório coberto por um véu negro, representando o monstro do ateísmo, e do meio das labaredas, com ruído de petardos, surgiu a estátua da Sabedoria sentada e parecendo ditar seus preceitos aos mortais.

O decreto de celebração da Festa do Ser Supremo projetava o culto com as seguintes invocações: Ao Ser Supremo e à natureza; ao gênero humano; ao povo francês; aos benfeitores da humanidade; aos mártires da liberdade; à liberdade e à igualdade; à república; à liberdade do mundo; ao amor à pátria; ao ódio aos tiranos e aos traidores; à verdade; à justiça; ao pudor; à glória e à imortalidade; à amizade; à frugalidade; à coragem; à boa-fé; ao heroísmo; ao

${ }_{5}^{4}$ Idem, vol. IV, pp. 561 e segs.

${ }^{5}$ A festa do Ser Supremo, interpretada como a festa de Robespierre, passaria a ser, para a Convenção pós-termidoriana, o paradigma da festa com escassa participação do povo, onde este foi ludibriado. Cf. THIONVILLE, Merlin de, Idem, op. cit., vol. V, p. 96.

${ }^{6}$ Idem, op. cit., p. 583. 
desprendimento; ao estoicismo; ao amor; à fidelidade conjugal; ao amor paterno. $^{7}$

Se pensarmos nos conceitos colocados lado a lado nessa sucessão, captaremos talvez um pouco melhor o contexto dos valores morais: a justiça entre a verdade e o pudor, a verdade entre a justiça e o ódio à tirania e à traição, a boa-fé entre a coragem e o heroísmo, o heroísmo entre o desprendimento e a boa-fé, o povo francês entre o gênero humano e os benfeitores da humanidade, o gênero humano entre o povo francês e o Ser Supremo e a natureza, etc. Estamos diante de uma recapitulação, não de uma ruptura da religiosidade revolucionária.

Surgiram hinos dedicados ao Ser Supremo por toda parte. E isto antes de Robespierre ter proclamado o seu culto oficial na Convenção. Aos poetas de renome uniram-se policiais, granadeiros, comissários de correios, funcionários de transportes, garçons, etc. ${ }^{8}$ Constant Pierre, compilador do cancioneiro da Revolução, comenta que encontra esses autores "assombrados pelo entusiasmo que prova como o sentimento da divindade estava profundamente enraizado no povo... Escreveram espontaneamente esses hinos e os enviaram às autoridades ou os publicaram". Quase todos datam de 1793-94.

David programara a festa do Ser Supremo nestes termos ${ }^{9}$ :

Mal a aurora anuncia o dia e já os sons de uma música guerreira retumbam por toda parte, fazendo com que à calma do sono suceda um despertar encantador.

Ante o aspecto do astro benfazejo que vivifica e colore a natureza, amigos, irmãos, esposos, crianças, anciãos e mães se abraçam e se apressam ativamente para adornar e celebrar a festa da Divindade.

Logo, inúmeras bandeirolas tricolores ondulam do lado de fora das casas; as portas são decoradas com festões e folhagem de todo tipo; a

${ }^{7}$ Collection Complète des Tableaux historiques de la Révolution Française, Paris, 1804, quadro $\mathrm{n}^{\circ} 100$.

${ }^{8}$ PIERRE, Constant, Les Hymnes et chansons de la Révolution, Paris, 1904, p.41.

9 VILlARS, M. Miette de, Mémoires de David, peintre et Député à la Convention, Paris, 1850, p. 127. CHÉNIER, M. -J., Détail des Cérémonies et de l'ordre à observer dans la fête à l'Être Suprême qui doit être célebrée le 20 Prairial, d'après le décret de la Convention Nationale du 18 floréal, an II. casta esposa trança com flores a cabeleira flutuante de sua querida filha, enquanto a criança de peito se aconchega ao seio de sua mãe, do qual constitui o mais belo atavio. $\mathrm{O}$ filho, com braço vigoroso, ostenta suas armas; não quer que ninguém a não ser seu pai lhe imponha o boldrié; o ancião sorri com prazer, e com os olhos umedecidos pelas lágrimas, sente que sua alma rejuvenesce, assim como a sua coragem ante esta cena, e apresenta a espada aos defensores da liberdade. ${ }^{10}$

Depois dessa representação da conjugação do amor pátrio com o amor familiar, surge o tema do deísmo celebrado em triunfo:

$\mathrm{Na}$ parte inferior do anfiteatro ergue-se um monumento onde achamse reunidos todos os inimigos da felicidade pública; dominando tudo, o monstro do ateísmo desolador. .. O povo está a postos. Em ordem, começa a partida. Avança em duas colunas: os homens de um lado, as mulheres de outro, marchando paralelamente. O batalhão dos adolescentes, disposto na forma de um quadrado, marcha sempre na mesma ordem.

A ordem das seções é determinada alfabeticamente. Em meio ao povo aparecem os seus representantes; as crianças acham-se adornadas de violetas. Os mirtos adornam a adolescência; o carvalho, a virilidade, e a oliveira e os pâmpanos, os anciãos de alvos cabelos. Cada representante leva na mão um ramo de espigas de trigo, flores e frutos, Símbolos da missão que lhe foi confiada, missão que cumprirá apesar dos obstáculos recorrentes.

No centro da representação nacional, quatro touros vigorosos, cobertos de festões e de guirlandas, puxam um carro sobre o qual brilha um troféu composto pelos instrumentos das artes e dos ofícios e pelos produtos do território francês.

Depois de ter - durante a marcha - coberto com oferendas e flores a estátua da liberdade, o cortejo atinge o campo da reunião.

Uma imensa montanha foi disposta como altar da pátria; em seu cume eleva-se a árvore da liberdade; os representantes se abrigam sob os seus ramos protetores; os pais com seus filhos se agrupam na parte da montanha que lhes foi designada; as mães com suas filhas se

\footnotetext{
${ }^{10}$ Esta cena parece evocar o Juramento dos Horáclos do próprio David.
} 
alinham do outro lado; as virtudes de seus esposos são os seus títulos de comparecimento.

Um profundo silêncio reina em toda parte; ouve-se então os acordes comoventes de uma música harmoniosa; os pais acompanhados por seus filhos cantam uma primeira estrofe; juram todos juntos não depor as armas antes que os inimigos da República tenham sido aniquilados: todo o povo repete em coro o final.

As filhas e suas mães, com os olhos postos no céu, cantam uma segunda estrofe: prometem casar unicamente com homens que tiverem servido a pátria; as mães se orgulham de sua fecundidade... Nossos filhos, dizem, depois de terem purificado a terra dos tiranos que se aliaram contra nós, voltarão para cumprir com o dever mais sagrado para o coração: fecharão as pálpebras daqueles de quem receberam a luz do dia.

O povo repete as expressões desses sentimentos sublimes, inspirados pelo amor sagrado às virtudes.

Uma terceira e última estrofe é cantada pelo povo inteiro; a emoção mais viva se agita por toda a montanha: homens, mulheres, moças, anciãos, crianças, todos fazem ecoar o som de suas vozes.

Neste instante as mães tomam seus filhos menores, ainda sem forças para acompanhar seus irmãos e os erguem nos braços, apresentandoos em homenagem ao autor da natureza.

As moças lançam ao céu as flores que carregavam, única propriedade de uma idade que deve ser singela.

No mesmo instante e simultaneamente, os filhos, com ardoroso afã guerreiro, desembainham as espadas, juram levá-las à vitória por toda parte, juram o triunfo da igualdade e da liberdade contra a opressão dos tiranos.

Os anciãos, maravilhados, abraçam-nos e dão-lhes a bênção paterna.

Uma formidável salva de artilharia, intérprete da vingança nacional, inflama ainda mais a coragem de nossos republicanos; anuncia-lhes que o dia da glória chegou. Um canto viril e guerreiro, antecipação da vitória, responde ao ruído do canhão.

Todos os franceses mesclam seus sentimentos num abraço fraterno; têm uma única voz, cujo grito - Viva a República! - sobe até a Divindade.

\section{Nas palavras de Miette de Villars ${ }^{11}$ :}

Para que o leitor aprecie todo o mérito patriótico desse programa sublime, será suficiente recordar que, nessa época, os exércitos estrangeiros já haviam invadido nosso território, que uma guerra geral nos espreitava e que, depois de ter repelido os exércitos coligados no Meuse, no Mosela e no Rena, precisávamos lutar contra os monarquistas fratricidas "que, com o ouro estrangeiro, nutriam a guerra ímpia da Vendeia.

Em suas convicções, David parecia esperar com boa-fé que a França aceitasse os costumes da Lacedemônia, esse programa (da festa do Ser Supremo), que pode ser considerado como seu testamento político, foi o último que leu na tribuna.

No discurso proferido na celebração da festa do Ser Supremo, Robespierre reitera a ideia de que as atitudes e obras generosas e heroicas dos humanos se devem à existência da divindade. A bondade humana é a taumaturgia divina. Como também o é o verdadeiro consolo ao desespero dos homens. Assim, a divindade tanto surge diante do mistério da bondade como diante do mistério da maldade. Os homens não são melhores do que seus deuses, segundo a metáfora antiga: são incompletos no que de maior e mais profundo possuem: no sofrimento e no amor. A divindade os completa e eleva.

Ser Supremo... Foi ele que insuflou no opressor triunfante o remorso e o medo, e no coração do inocente oprimido a calma e a segurança; é ele que força o homem justo a aborrecer o mau, e o mau a respeitar o homem justo; foi ele que adornou com o pudor a fronte da beleza para torná-la ainda mais bela; é ele que faz palpitar de alegria e ternura as entranhas maternas; é ele que faz calar as paixões mais ternas e imperiosas ante o sublime amor à pátria; foi ele que cobriu a natureza de encantos, riquezas e majestade. Tudo que é bom é obra sua ou é ele mesmo; o mal pertence ao homem depravado que oprime ou tolera a opressão de seus semelhantes. ${ }^{12}$

Os irmãos Say e Ginguené eram os promotores da Décade Philosophique, littéraire et politique, cujo lema era "As luzes e a moral são

${ }^{11}$ VILLETTE, Charles, Lettres Choisies, Paris, 1792, p. 127.

${ }^{12}$ La Décade Philosophique, littéraire et politique, Paris, ano II, p. 341. 
tão necessárias à manutenção da República como a coragem o foi para conquistá-la”. A propósito da festa do Ser Supremo, comentou ${ }^{13}$ :

Os mal-intencionados devem ter visto com rancor a impotente calma do povo já livre de seus erros, imbuído do respeito para com o Eterno. Esse povo espera da Convenção uma religião simples como a natureza, pura como a verdade e eterna como a razão. É-nos necessária uma religião tão útil à liberdade como à felicidade humanas. Povo, espera com respeito o relatório do Comitê (de Instrução) sobre as festas decadárias; não permitas mais a ofensiva do fanatismo: adora a um Deus, sê justo, benfazejo, ama a tua pátria e serás digno do Ser Supremo; denuncia os maus que querem ressuscitar a superstição; ilumina os homens de boa-fé; leva-os à razão, à verdade, e em breve poderemos oferecer à divindade um culto tão puro como a liberdade.

A Décade Philosophique saudou o "gosto antigo" da festa do Ser Supremo na concepção davidiana. Considerou que a festa não tinha paralelo em outro povo, que era "instituída pela filosofia, não a divindades absurdas, não aos atributos, aos símbolos da essência divina, mas diretamente ao autor da natureza, à causa das causas, ao Ser infinito, imutável e eterno". ${ }^{14}$

${ }^{13}$ Idem, op. cit. Aqueles que se integraram ao Instituto Nacional no outono de 1795 também haviam sido colaboradores de La Décade Philosophique. Eram eles: Volney, Garat, Cabanis, Lakanal e Naigeon. Cf. AULARD, A., Le Christianisme et la Révolution Française, Paris, 1925, p. 149.

${ }^{14}$ La Décade..., op. cit., p. 340.

\section{O ramo seco}

Na celebração do Ser Supremo, a identidade dos sans-culottes atingia $\mathrm{o}$ auge. $\mathrm{O}$ valor de sua dignidade pessoal, acima da demagogia e à margem da submissão, parecia ter-se realçado firmemente com Robespierre, sem prejuízo dos defeitos que o próprio Robespierre tentava reduzir.

Contudo, essa dignidade estava muitíssimo ameaçada pela plutocracia ascendente que, com a cumplicidade de todos os aristocratizantes, conseguiu criar a imagem da ditadura de Robespierre, do terror e da degeneração dos sans-culottes. Diante deste quadro tão difundido da Revolução Francesa, que boa parte da moderna historiografia quer realçar, citaremos apenas uma lembrança, uma evocação da relação entre Robespierre e os sans-culottes, que nos é transmitida por Renan em suas memórias. ${ }^{1}$

Renan, fascinado pela antiguidade clássica e pela figura de Jesus Cristo, é quem nos conta a história do francês que guardou, embora seco, todo o ramo das ideias filosóficas e jacobinas que culminavam com a Convenção robespierrista. Tratava-se de um velho revolucionário que Renan conheceu na juventude e que lhe incutiu tamanho respeito que Renan chegou a afirmar sobre ele:

Sem possuir a aura poética que o século XIX acrescentou às grandes verdades, Systeme (apelido do personagem), tenho certeza, viu muito acima e muito além. Ele estava de posse da verdade.

Systeme morreu sozinho e muito velho, sem deixar nenhum bem que sua existência modesta não permitisse imaginar; foi encontrado "num canto, cuidadosamente embrulhado, um ramo de flores já muito secas, atado com uma fita tricolor...". A princípio se pensou tratar-se de alguma lembrança de origem afetiva... mas a fita tricolor... Logo descobriu-se que no verso do papel que o envolvia estava escrito: "Ramo que portei na festa do Ser Supremo em 20 do prairial do ano II".

\section{Renan reagiu:}

Lembrei-me dos raros adeptos da Igreja jacobina que pude conhecer, de sua ardente convicção, de seu carinho ilimitado pelas recordações

${ }^{1}$ RENAN, E., Souvenirs d'enfance et de jeunesse, Paris, 1891 (16 a ed.), pp. 110-111. 
de 1793 e 1794, de sua incapacidade em falar de outra coisa. Esse sonho que durou um ano foi tão poderoso que os que o viveram não puderam adotar outra vida. Permaneceram sob a força de uma ideia fixa, taciturnos, cheios de estupefação; tinham o delirium tremens da embriaguez dos combates sangrentos. Eram crentes absolutos. O mundo que já não soava em uníssono com seu diapasão parecia-lhes vazio e infantil. Ficaram sozinhos e inabaláveis, como restos de um mundo de titãs, carregados de ódio pelo gênero humano, sem relação possível com os vivos. Compreendi o efeito que Lakanal provocou ao voltar da América em 1833 e aparecer diante de seus colegas da Academia de Ciências Morais e Políticas como um fantasma.

Lakanal regressou em 1837, e até sua morte, em 1845, não pôde fazer nada além de redigir memórias da Revolução, escritas com um caráter de grandeza mais fácil de compreender do que de caricaturar para aquele que conhece o contexto.

\section{UTOPIA E REAÇÃO CONSERVADORAS}

\section{De Maistre: providencialismo e razão cínica}

Saint-Martin, com arroubos de sublimidade, e Joseph de Maistre, munido de cínicas obsessões, são os intérpretes mais destacados da Revolução Francesa como obra da divina providência. ${ }^{1}$ Para essa interpretação terão papel; importante as noções de ascese e de sacrifício em consonância com determinadas representações do atavismo cristão. Contrastarão com essa posição os esforços de um Chateaubriand para apresentar o cristianismo de acordo com a estética e o culto da beleza, segundo o romantismo que ele mesmo preconiza.

Nas palavras de Viatte, "'a religião cativa Joseph de Maistre: nela vê, concomitantemente, como muitos místicos, uma obra divina e demoníaca. Julga-a 'tão maravilhosa em seu gênero' como a súbita frutificação de uma árvore no mês de janeiro".

Paradoxalmente, Joseph de Maistre atribui ao catolicismo reacionário as ideias cínicas que derivam do deísmo maçônico mais frio: um ser supremo cuja única Providência é a da necessidade natural, a única que pode ser chamada de vontade divina ${ }^{3}$ :

${ }^{1}$ VIATTE, A., Les sources occultes du Romantisme, Paris, 1969 (1927), t. I, p.279.

A relação entre a providência divina e o mandato de Robespierre do ponto de vista contrarrevolucionário, que de Maistre elevaria ao estatuto de chave ideológica fundamental, já era pressentida por alguns setores da população; embora, como evidencia o trecho abaixo, das memórias de Aiouffe, tal relação evocava mais o Antigo Regime do que uma situação sem precedentes:

"O povo, com esse choque tão violento (Robespierre), deslocara-se para trinta anos antes da revolução, e parecia dizer que isto vem de cima, tal como fazia com o despotismo. Vário séculos de obediência passiva haviam-no feito adquirir essa atitude demasiado funesta ante uma grande injustiça que assombra sua moralidade. Essa locução não será eliminada num dia, especialmente quando ainda houver um governo revolucionário. Entretanto, um país não é livre nem digno de sê-lo quando vigora essa expressão servil; e dizem ante uma opressão, ao invés de repeli-la: isto vem de cima". AIOUFFE, Honoré, Mémoires d'un détenu pour servir à l'histoire de la tyrannie de Robespierre, Paris, ano III (1794-95), p. 21 Idem, op. cit, t. II, p. 83.

${ }^{3}$ MAISTRE, Joseph de, Considérations sur la France, Londres, 1797, p. 9. 
Estamos todos atados ao trono do Ser Supremo por meio de uma corrente leve, que nos prende sem nos subjugar.

O que há de mais admirável na ordem universal das coisas é a ação dos seres livres sob a mão divina. Livremente escravos, agem voluntária e involuntariamente ao mesmo tempo: fazem realmente o que querem, mas sem poder perturbar os planos gerais. Cada um destes seres ocupa o centro de uma esfera de atividade cujo diâmetro varia conforme o desejo do geômetra eterno, que sabe ampliar, contrair, parar ou dirigir-lhe a vontade sem alterar sua natureza... Imaginando um relógio cujas molas variassem continuamente de força, peso, dimensão, forma e posição e que, contudo, indicasse invariavelmente a hora, poderemos ter alguma ideia da ação dos seres livres em relação aos planos do Criador... Se no coração do inverno ${ }^{4}$ um homem ordenar a uma árvore, perante mil testemunhas, que se cubra imediatamente de folhas e de frutos, e a árvore obedecer, todo mundo reconhecerá o milagre, e se inclinará ante o taumaturgo. Mas a Revolução Francesa, e tudo que está acontecendo na Europa neste momento, é tão maravilhoso, em seu gênero, como a súbita frutificação de uma árvore no mês de janeiro: entretanto, os homens, ao invés de se admirarem, olham para outros lados ou deliram.

Passando a examinar mais de perto o fenômeno da Revolução, Maistre considera-o totalmente interpretável segundo seu esquema ${ }^{5}$ :

Enfim, quanto mais se examina os personagens aparentemente mais ativos da Revolução, mais se encontra neles algo de passivo e mecânico. Não é supérfluo repetir: não são de forma alguma os homens que dirigem a Revolução, é a Revolução que comanda os homens. E acertado dizer que a Revolução caminha sozinha. Esta frase significa que a Divindade nunca se manifestara de maneira tão clara num acontecimento humano. Se emprega tão vis instrumentos, é por que castiga para regenerar.

De Maistre parece querer identificar o motor deísta ao motor de um sistema social, sintetizando um providencialismo sócio-lógico. Esta ideia fará dele um precursor da sociologia durkheimiana, baseada na importância da religião para a existência de uma sociedade enquanto entidade com força própria.

${ }_{5}^{4}$ Metáfora que homenageia a Revolução, apesar do que de Maistre virá a afirmar a seguir. ,op. cit., p. 15.
Na argumentação do conde de Maistre, a França é castigada por Deus porque, sendo a primeira nação cristã do mundo, deu o pior exemplo. Seu grande crime foi o regicídio. Mas o castigo divino usou os próprios criminosos como verdugos. Desta maneira, os contrarrevolucionários virtuosos não tiveram que aplicar o rigor da justiça. Os criminosos degolaram-se entre si. Ao mesmo tempo, Robespierre agiu providencialmente ao endurecer o coração dos franceses, pois assim estes se lançaram numa guerra impiedosa e mantiveram intacto o território francês. De outra forma os exércitos coligados poderiam ter vencido, dividindo entre eles o solo pátrio. "Se a Providência apaga, é sem dúvida para tornar a escrever: a Revolução purificou o clero". A Revolução é a “pura impureza”.

De Maistre acrescenta a essa interpretação baseada na força da revulsão, a do poder redentor das vítimas: "a reversibilidade das dores da inocência em benefício dos culpados", algo em que Sade provavelmente teria visto uma algolagnia metafísica. Em sua obra Esclarecimento sobre os sacrifícios, ${ }^{6}$ de Maistre desenvolve o tema do poder redentor dos sacrifícios: a salvação dos pecadores, dos ímpios, só pode ser obtida com o sangue dos inocentes. O grande saber da Redenção. De outra maneira, se o malvado se salvasse sem o concurso da vítima, seria reconhecida uma certa capacidade benfazeja ao mal. Como este não pode tê-la de forma alguma, a salvação só pode proceder - e tem então um poder redentor - da opressão, do sacrifício dos inocentes.

Contudo, a Providência tolerou a irrupção do poder satânico na Revolução de uma forma assombrosa ${ }^{7}$ :

Na Revolução Francesa há um caráter satânico que a distingue de todo o resto. Recordemos as grandes sessões! O discurso de Robespierre contra o sacerdócio, a apostasia solene dos sacerdotes, a profanação dos objetos de culto, a criação do culto da deusa Razão e essa multidão de cenas inauditas onde as províncias procuravam superar Paris; tudo isto vai além do círculo ordinário dos crimes e parece de outro mundo.

Por outro lado, para de Maistre, o retomo da monarquia e da religião católica são uma mesma coisa, e ele escreve o seguinte ante a influência do

Les soirées de Saint-Pétersbourg, Paris, s.d. Considérations..., p. 63. 
espírito acomodatício e pusilânime que caracteriza especialmente o período do Diretório ${ }^{8}$ :

... o retomo à monarquia, longe de gerar os males que temeis, fará com que cessem os que agora vos consomem; todos os vossos esforços serão aproveitados; não destruireis senão a própria destruição.

Desenganai-vos para sempre dessas doutrinas desoladoras que desonraram nosso século e levaram a França à perdição. Já aprendestes a conhecer os pregadores desses dogmas tão funestos; mas a impressão que vos causaram ainda é visível. Em vossos planos de criação e de restauração só esqueceis de um Deus - fostes separados dele: não é através de um esforço de raciocínio que ele vais os pensamentos à fonte inesgotável de toda existência. Não quereis ver senão o homem; sua ação tão fraca, tão dependente, tão circunscrita; sua vontade tão corrupta, tão leviana; e a existência de uma causa superior não passa para vós de uma teoria. No entanto vos intimida, vos assedia: notais seu contato e o universo inteiro a anuncia a vós. Quando vos dizem que sem ela não tereis força alguma a não ser a da destruição, não se trata de nenhuma especulação vã, mas de uma verdade prática, baseada na experiência dos séculos e no conhecimento da natureza humana. Observai a história e não vereis criação política alguma, que digo, não vereis uma única instituição, seja qual for, que por pouca força e duração que tenha, não precise repousar numa ideia divina, por mais diversa que seja a natureza desta última, já que também não há sistema religioso algum que seja inteiramente falso. Não nos faleis, pois, das dificuldades e desditas que vos alarmam como consequências do que chamais de contrarrevolução. Todas as desgraças que vivestes procedem de vós mesmos. Por que não vos feriram as ruínas do edifício que derrubastes sobre vossas cabeças? A reconstrução é uma coisa bem diferente; entrai na senda que pode vos conduzir a ela. Não é pelo caminho do nada que chegareis à criação.

De Maistre engana-se tanto como Robespierre ao querer moralizar a contrarrevolução, porque o que manterá será um sistema surdo a estas considerações, assim com acontecia com a moral revolucionária e a economia burguesa. Mas de Maistre, ao notar a falência da ação

\footnotetext{
${ }^{8}$ Idem, op. cit., p. 128
}

moralizadora, recorre a ideias mais cínicas: já que a construção não aparece, a própria destruição é que deve ser a ação da Providência. Nesse sentido surgem seus famosos elogios do verdugo e da guerra'

Quem é este ser inexplicável que preferiu a todos os ofícios agradáveis, lucrativos, honestos e inclusive honrosos, que se oferecem abundantemente à força e à habilidade humanas, o de atormentar e matar seus semelhantes? Essa cabeça e esse coração são como os nossos? Não contêm nada de particular e estranho a nossa natureza? Quanto a mim, não poderia duvidar disto. Exteriormente é como nós, nasce como nós, mas é um ser extraordinário, e para que surja na família humana é preciso um decreto particular, um fiat do poder criador. É criado como um mundo... A ele são entregues um envenenador, um parricida, um sacrílego: prende-o, estira-o, atando-o sobre uma cruz horizontal, levanta o braço: faz-se então um horrível silêncio e só se ouve o estalido dos ossos que se partem sob a barra e os alaridos da vítima. Desata-a e a coloca em cima de uma roda: os membros quebrados são enlaçados aos raios da roda, a cabeça pende, os cabelos se eriçam e a boca se abre como um forno, emitindo a intervalos regulares umas quantas palavras sanguinolentas que pedem a morte. O verdugo terminou: bate-lhe o coração, é de satisfação; aplaude-se e diz a si mesmo: Ninguém manipula a roda melhor do que eu. Desce: estende a mão manchada de sangue e a justiça, de longe, atira-lhe algumas moedas de ouro. Desfila por entre duas fileiras de homens que se afastam com horror à sua passagem... No entanto, toda grandeza, todo poder, toda subordinação repousam no verdugo: é o horror e o nexo da associação humana. Afastai do mundo esse agente incompreensível; no mesmo instante a ordem dá lugar ao caos, os tronos caem e a sociedade desaparece. Deus, que é o autor da soberania, também o é do castigo: fez a terra com esses dois pólos e ao redor dos mesmos faz girar o mundo.

Assim, o mal é uma criação do próprio Deus para extrair um bem indiscutivelmente maior que o homem só é capaz de perceber um pouco. A incompreensão, a fatalidade e o horror do próprio mal já devem sugerir sua procedência divina. De Maistre percebe essa superioridade no mal como indicação de sua origem divina, de uma maneira que faz evocar muito a forma como Sade o percebe, independente por sua inexorabilidade e poder.

\footnotetext{
${ }^{9}$ MAISTRE, J. de, Les soirées ..., p. 27
} 
Sade materializa todo o impulso destrutivo e, se este lhe parece algo misterioso, sintetiza-o com a paixão erótica, que também pode parecer algo misterioso, os dois juntos parecem irrefutáveis. Joseph de Maistre diviniza a fúria da destruição, assimilando-a à destrutividade universal que, por sua extensão, acredita ser pertinente aos atributos ou vontade de Deus ${ }^{10}$ :

O homem subitamente possuído por uma fúria divina, diferente do ódio e da ira, avança no campo de batalha sem saber o que quer nem sequer o que faz. Qual é este horrível enigma? Nada é mais contrário a sua natureza, nada lhe causa mais repugnância: faz com entusiasmo o que considera horroroso... Assim cumpre-se sem cessar, do inseto ao homem, a grande lei da destruição violenta dos seres vivos (também um tema sadiano). A terra inteira, continuamente embebida em sangue, não é senão um imenso altar onde tudo que vive deve ser imolado, sem fim, sem medida, sem descanso, até a consumação das coisas, até a morte da morte... A guerra é portanto divina nela mesma, é uma lei do mundo.

A guerra é divina em decorrência de suas consequências de ordem sobrenatural, tanto gerais como particulares... A guerra é divina na misteriosa glória que a rodeia e na atração não menos inexplicável que nos leva a ela... A guerra é divina em virtude da maneira como é declarada... A guerra é divina por causa dos resultados que escapam totalmente às especulações da razão humana... A guerra é divina pela força indefinível que determina seus êxitos.

Quinet dá conta de modo certeiro da incongruência e, ao mesmo tempo, do sucesso da visão de de Maistre: sua mistura de sacrifício e terror, de salvação e poder. O encontro cínico de extremos para definir a fórmula da religião contrarrevolucionária ${ }^{11}$ :

De Maistre... opõe, em tese, o terrorismo da Igreja ao terrorismo da Convenção. Seu Deus inexorável, assistido pelo verdugo... Essa teologia tem, no fundo, o absolutismo da Convenção, sem a esperança de libertação antes do fim do mundo, Robespierre sem Rousseau, o meio sem o fim. O ódio do catolicismo à Revolução é tão grande que para aniquilá-la em suas origens a religião pretende optar pelas mesmas armas. Disputa-lhe o inferno, repele o seu céu.

\footnotetext{
${ }^{10}$ Idem, p. 122.
}

${ }^{11}$ QUINET, E., Oeuvres Complètes, t. III, 1857 (1845, F ed.), Paris, p. 237.

\section{De Bonald: utopias do conservadorismo}

Se Robespierre tentava condicionar moralmente a política, partindo do princípio de que a política por si só não pode mudar a sociedade, nem mantê-la numa ordem vigorosa, de Bonald procurava evitar o conflito entre moral e política, tal como emergia no cristianismo ilustrado e revolucionário. Com alguns raciocínios silogísticos de Bonald acreditava poder fundamentar uma relação estável entre a moral e a política ${ }^{1}$ :

Assim, será possível dizer que a política é para os governos o que a moral é para os particulares, ou, transpondo os termos como numa equação, que a política deve ser a moral dos Estados, e a moral, a política dos particulares; ou ainda, que a boa política é a grande moral, a moral pública, por oposição à moral propriamente dita, que é a moral privada; expressões diferentes que apresentam no fundo o mesmo sentido, e que não fazem mais do que desenvolver melhor a relação entre estes dois reguladores das ações públicas e privadas.

Estamos dando apenas definições. Mas as definições exatas são a chave das ciências. Têm a vantagem de fixar o pensamento desde o começo e de proporcionar noções que são ao mesmo tempo precisas e extensas dentro de uma forma simples e abreviada.

A política e a moral são semelhantes inclusive quando se comportam como máximas que aparentemente se opõem. Assim, a moral proíbe o homem de atentar contra a vida alheia e também de desejar a propriedade do próximo. Entretanto, a política ordena ou permite que os governos tirem a vida dos maus, e até disponham da dos bons, para o legítimo serviço da sociedade. Ordena ou permite que se disponha da propriedade particular por meio do imposto, ou se apossa dela através do direito de expropriação, transformando-a num objeto de utilidade pública.

A moral diz ao homem que não se deve fazer ao outro o que não se quer para si mesmo; contudo, esta máxima de verdade eterna supõe uma igualdade perfeita entre os homens e não pode, portanto, ser útil na sociedade pública, como tampouco na doméstica, pois que magistrado ou pai de família se submeteria a todos em que ele

${ }^{1}$ BONALD, L. de, Mélanges Littéraires, Politiques et Philosophiques, Paris, 1819, t. I, pp. 186-194. 
mesmo deve mandar, ou a quem deve ordenar serviços ou infligir castigos?

Contudo, se a política e a moral se diferem pelas pessoas a que se aplicam e pelos meios empregados, por seus princípios e objetivos se assemelham, já que a finalidade da moral é a conservação física do homem e sua perfeição moral, e o fim da política deve ser a conservação e a perfeição da sociedade.

Talvez venham a objetar que os governos mais bem organizados estabelecem ou toleram coisas que parecem incompatíveis com a moral sã. É fácil responder que, de maneira geral, tudo o que um governo estabelece de oposto à moral, também é oposto à política; o que prova, melhor do que qualquer outra coisa, a estreita conexão entre seus princípios. Quanto às tolerâncias, como por exemplo a livros perigosos, espetáculos licenciosos, prostituição, etc., estabelecidas por um certo tempo, devem ser consideradas fraquezas que o mais moral dos governos não pode combater em sua totalidade; algo parecido ao que acontece com essas faltas que escapam ao mais virtuoso dos homens, das que procura se corrigir durante toda a vida, por vezes sem nunca conseguir.

Um governo que adotasse a moral privada como norma de sua conduta pública não conservaria a sociedade e poderia ser opressor por debilidade, assim como o particular que adotasse a política como norma de suas ações privadas seria, pelo uso da violência, opressor de seus semelhantes.

Podemos dar exemplos desse duplo erro.

Vimos governos que, adotando ao pé da letra os preceitos da moral privada, prática que chamavam de filantropia, aboliam a pena de morte, esse primeiro meio de conservação da sociedade. Temos diante de nossos olhos seitas inteiras, como os quackers, que se abstêm da guerra e de jurar perante os tribunais por considerar essas coisas ilegítimas e contrárias aos princípios da moral: também podemos dar-nos conta da existência, na escola filosófica do século XVIII, de um propósito geral e habitual de tornar a política odiosa, servindo-se do zelo pela moral. As imprudentes declamações desses escritores provocaram desvios na política sem proveito para a moral e intimidaram os governos. Foi muito fácil reconhecer esta influência secreta na conduta dos que estavam à testa dos assuntos da França no começo da revolução.
É aí que a pequena moral mata a grande, para citar uma conhecida frase de Mirabeau...

Um particular que, para corrigir os males causados a seus bens ou a sua pessoa, ao invés de dirigir-se aos tribunais decidisse enfrentar diretamente seus inimigos ou apropriar-se pela força das propriedades de seu vizinho, estaria se orientando pelas leis da política, leis que só podem ser aplicadas aos governos, e não pelas leis da moral privada, que regulam as relações recíprocas dos particulares dentro da sociedade; assim, a grande moral mataria a pequena.

No entanto, o particular, ou antes a sociedade familiar, pode recuperar $\mathrm{o}$ exercício da força, que the pertencia antes do estabelecimento das sociedades públicas. Na primeira idade de todos os povos, no estado de família ou no estado privado, a moral privada permite as guerras privadas, e ainda as permitiria, segundo o grande princípio da conservação, em todos os lugares onde faltasse à sociedade pública poder ou vontade de empregar a força pública para proteger os particulares e onde a mesma fosse, por conseguinte, como que inexistente em relação aos particulares.

A esta situação se chega por meio dessa "filantropia" que enfraquece os governos. Segundo de Bonald, a reforma filantrópica seria a causa do despotismo privado:

Assim, em todo lugar onde a pequena moral mata a grande e onde os governos, com falsas ideias de humanidade, abjuram o poder que o próprio Deus lhes concedeu e o dever que lhes é prescrito, o de reprimir e castigar, acontece, com toda certeza, que a grande moral mata a pequena, e o particular arroga-se o direito de fazer justiça por conta própria, direito que o governo então não exerce...

Nas épocas ordinárias, e sob um governo conhecedor de seus deveres, o particular não se vê tentado a tratar os demais segundo a lei da política em detrimento da moral... Mas em épocas de revolução, quando todos os simples cidadãos acreditam ser soberanos, magistrados, poderosos ou emissários do poder, impera apenas a lei política, e a moral não conta para nada.

De Bonald nos sugere que a imensa maioria de filósofos e iluministas, incluindo Rousseau, moralistas de política ordinária, não teriam aprovado a "grande moral" da Revolução, e poderiam inclusive ter 
sido suas vítimas mais notáveis. É interessante destacar que, em compensação, os demais ideólogos próximos do conservadorismo mais ou menos reacionário defendiam a continuidade entre o Iluminismo e a Revolução. Dos líderes revolucionários, destacou apenas Robespierre em sua crítica à maioria dos filósofos iluministas como alheios à Revolução.

Por outro lado, de Bonald dá grande impulso ao conservadorismo como crítica - embora com o idealismo retrógrado apontado por Marx - e utopia ante a nova sociedade capitalista. Como bem assinalou David Klinck, ${ }^{2}$ trata-se de um confronto com o "estado burocrático racionalizado e com o capitalismo de grande escala", não com o liberalismo que emerge como oposição ao regime senhorial. Assim, de Bonald aproxima-se em parte à trajetória de Lamennais, sem, no entanto atingir o desenvolvimento das contradições do sacerdote tão católico e tão cristão.

Em sua obra onde criticaria o Diretório, ${ }^{3}$ de Bonald manifestava a teoria da primazia da sociedade na ordem das necessidades humanas. A propriedade seria a materialização fundamental dessa necessidade, na medida em que relaciona os indivíduos entre si enquanto seres livres $e$ capazes. Até aqui, as ideias de de Bonald não são mais originais do que as de Locke ou Rousseau. Mas de Bonald vai mais longe: caracteriza a sociedade como um ser, um organismo (com características que o aproximam de Spencer) constituído de famílias, que, por sua vez, são definidas como unidades naturais desta sociedade. A família e a moral ou religião natural só servem para a produção da sociedade, para que ela possa existir e crescer numericamente. Agora, para que um tipo de sociedade, além de produzir-se - existir e crescer - possa conservar-se, em sua própria ordem, necessita de um tipo de religião e de um tipo de política. Assim chegamos ao sentido do conservadorismo segundo de Bonald: para que a sociedade de nossa civilização possa conservar - senão apenas existir e crescer numericamente -, precisa de duas instituições: o cristianismo e a monarquia. Estas são as únicas que conservam a sociedade ocidental. Em outras palavras, de Bonald distingue a produção de uma sociedade e a

${ }^{2}$ KLINCK, David M., "An examination of the notes de lecture of Louis de Bonald: at the origins of the ideology of the radical right in France", em Studies on Voltaire and the eighteenth century, Oxford, julho de 1983.

${ }^{3}$ BONALD, L. de, Théorie du pouvoir politique et religieux dans la société civile, Paris, 1796, 3 v. (exemplares censurados). reprodução da mesma em termos de suas condições de estabilidade. E esta estabilidade ou ordem social se devem: $1^{\circ}$ ao cristianismo, pois dota o homem do amor e do temor necessários para que, com o seu sacrifício, mantenha a sociedade; $2^{\circ}$ à monarquia, porque constitui a melhor analogia humana da relação do homem com Deus, e porque já foi criada como tal; quer dizer, a monarquia está incluída no plano divino da criação, assim como a família o está para a reprodução da espécie.

De Bonald não aceita o progresso humano segundo o quadro de Condorcet porque alega que o progresso moral, que deve ser entendido como o único progresso social, não coincide com o progresso científico, que é um fenômeno individual e do qual não deriva uma sociedade melhor. ${ }^{4}$ Ideia clássica e que de Bonald complementa com a utopia conservadora: a propriedade na fundamentação da ordem social e da capacidade social humana; de onde decorre que a propriedade é imprescindível para a dignidade do homem. Se esta faltar, a sociedade deve sanar a incompletude, considerada moralmente relevante ${ }^{5}$ :

O homem social é o homem e a propriedade, posto que a natureza da sociedade tende a tornar todos os homens sociais, chama-os a todos à propriedade. Mas o homem só pode aceder à propriedade através de um trabalho legítimo; todo homem deve portanto ocupar-se de um trabalho permitido para chegar a ser proprietário, e elevar-se assim ao estatuto de homem social. Como o homem não pode trabalhar sem adquirir alguma propriedade, pode-se dizer que todo homem que trabalha é um homem social, e todo aquele que não trabalha está fora da sociedade.

Assim, o homem é ou não é proprietário. Se não é proprietário, e está privado das faculdades físicas e morais indispensáveis para sê-lo por meio do trabalho, então a sociedade civil, quer dizer, a sociedade política e a sociedade religiosa, deve suprir a falta de suas faculdades e prover sua subsistência, já que deve aliviar todas as fraquezas físicas e morais do homem. Este é o objetivo dos hospitais públicos e demais fundações de caridade... Esses estabelecimentos onde todas as fraquezas humanas, físicas e morais, encontram socorro e asilo, ensinam ao povo que a desgraça é de todos os tempos e a religião de

\footnotetext{
${ }^{4}$ Idem, op. cit., vol. 2, pp. 500 e segs.
}

${ }^{5}$ Idem, t.III, pp. 195 e 198. 
todos os séculos; que se a natureza ordena ao homem o trabalho, a religião não permite que o cristão se inquiete com sua subsistência, veneno do coração humano, fonte de atentados e injustiças, e em suas necessidades mais extremas lhe oferece recursos que não prejudicam seu amor-próprio, já que não reduzem em nada a independência em relação ao seu semelhante.

O homem que não é proprietário e que não quer trabalhar para sê-lo, tendo o livre-arbítrio sobre suas faculdades físicas e morais, deve ser obrigado a trabalhar pelos poderes reunidos da sociedade religiosa e da sociedade política. Uma, para que determine a vontade, a outra, para que obrigue o corpo, se for necessário, porque tanto uma como outra devem fazer de todo homem um válido, um membro da sociedade, um homem social, um proprietário. Por outro lado, o homem que não vive de sua propriedade, vive necessariamente da de outro: por conseguinte, está forçando outro a trabalhar para sua subsistência; portanto oprime alguém na sociedade; então, o poder da sociedade política, instituído para defender a liberdade de todos contra qualquer espécie de opressão, deve obrigar o preguiçoso válido a fazer o gênero de trabalho adequado às suas faculdades físicas e morais.

Entretanto, de Bonald não é contra as grandes propriedades, pois diz que, apesar de dificultarem o desenvolvimento das menores, são mais aptas a darem trabalho aos não-proprietários do que uma propriedade do mesmo tamanho porém composta de várias pequenas. A pobreza pode e deve ser aliviada, mas não se pode esperar que desapareça ${ }^{6}$ :

De resto, é preciso voltar à máxima do grande mestre: 'sempre tereis pobres convosco'; diante disto, o mais importante é apresentar aos olhos do homem feliz a humanidade que sofre, e aos do pobre a riqueza benfazeja; a administração fará tudo que lhe for possível, mas nunca chegará a aliviar todas as misérias individuais; as diferentes assembleias que oprimiram a França arruinaram os ricos sem poder alimentar os pobres e, impotentes em lhes proporcionar pão e trabalho, decidiram, sem outro recurso, enviá-los a perecer nos exércitos. E mesmo quando a administração pudesse aliviar todas as misérias, deveria guardar-se de subtrair à caridade particular um incentivo necessário, meio poderoso de aproximar as diversas

${ }^{6}$ Idem, t. III, p. 202 condições; numa sociedade em que não existisse ninguém a quem aliviar, só haveria egoístas, cujo coração insensível às desgraças dos demais só saltaria à vista do ouro, só palpitaria ante o temor de gastálo. Nessas sociedades, só se conheceria uma virtude: a riqueza; um vício: a pobreza. Contemplai a fúria, a sanha de adquirir que devora, que consome a nação europeia, antes a mais desprendida, desde que as instituições republicanas estabeleceram o poder particular, o amor por si mesmo, em lugar do poder geral, do amor pelos outros. A religião aproxima a pobreza e a riqueza de forma admirável; fazendo do trabalho um dever e da mediocridade uma felicidade, convida o pobre a tornar-se rico por meio de seu trabalho e o rico a tornar-se pobre através de sua beneficência. Assim previne o perigo do ócio no pobre e o da dureza no rico: consola aquele que, em virtude de sua condição, poderia entregar-se ao desespero e faz com que tema aquele que, por sua fortuna, poderia encher-se de orgulho; santifica com o preceito da esmola, a riqueza, resultado necessário do trabalho que ela prescreve, proíbe o apego às riquezas que degrada o homem por torná-lo escravo da propriedade e não o seu verdadeiro dono; a própria religião torna o homem pobre no meio de riquezas, da mesma maneira como o torna austero no meio dos prazeres; já que a religião permite usar de tudo e não abusar de nada.

Desse modo, de Bonald condiciona a caridade cristã por meio da propriedade, e não ao contrário como Fauchet e os revolucionários evangélicos. A propriedade em de Bonald mantém-se como realização social da dignidade humana - já que o trabalho em si não apresenta essa qualidade - e como vocação de caridade. A propriedade é o ponto de partida para os posteriores acertos políticos e morais. Essa ideia não está distante da ideia de Robespierre: a indiscutível propriedade se condicionaria em parte pelo controle da legislação e da administração e pela consciência moral adquirida pelos cidadãos.

De Bonald propõe a caridade ou a filantropia do catolicismo conservador como antídoto para os excessos da sociedade que ele critica por seu individualismo burguês. De modo análogo a Robespierre, não acredita na possibilidade da política por si só aliviar o sofrimento humano. Ambos fazem apelo às suas morais respectivas para paliar os limites da ordem social, ultrajantes para o homem. Entretanto, é preciso repetir que em de Bonald a propriedade aparece com mais força como condicionante teórico do que em Robespierre. Na história das ideias da Revolução, isto 
quer dizer que o esquema ideológico robespierrista está mais próximo ao do evangelismo revolucionário que ao do conservadorismo reacionário. O que mais caracteriza este último é fazer da necessidade da propriedade, antes considerada um defeito, uma virtude. Virtude necessária no entender da utopia conservadora, que deseja a propriedade para o maior número de pessoas, pois é a garantia - social - da dignidade humana.

\section{A SOMBRA DE JEAN-JACQUES}

\section{Restif de la Bretonne, Mercier e Chateaubriand: mística e miséria}

Ao lado do Rousseau do Contrato Social, da Constituição para a Polônia, da moral do cidadão, etc., existe o Jean-Jacques das Confissões, das Rêveries, da moral do ser humano, etc. Se a manifestação mais oficial da Revolução Francesa parece ter dado mais atenção a Rousseau, outras testemunhas da Revolução, com menos destaque oficial na mesma, concentraram-se mais em Jean-Jacques. Sua sombra parece ter influenciado o surgimento de uma sensibilidade entre o realismo, a mística naturalista e a avaliação estética da moral. De certa maneira, esse fenômeno pode ser considerado o resíduo romântico da Revolução.

A Revolução concebera um esforço de titãs para regenerar a vida social. Ao mesmo tempo, a miséria moral e material havia se afirmado com o triunfo excessivo do novo capitalismo. Os magníficos desejos se familiarizavam cada vez mais com a vasta e profunda miséria. $\mathrm{O}$ novo homem de letras, se não renunciava à grande esperança humana que trouxera a Revolução, não podia esquecer a realidade social tão aguda. E se prestava bem atenção nesta, sendo a Revolução já considerada como uma fraude, como um fracasso ou como uma ilusão, só lhe restava o ensaio de uma nova rebelião ou uma contemplação mística da miséria, uma atribuição de outra religiosidade aos fatos sociais já aceitos como irreparáveis. Assim sendo, um bom número de homens letrados procurou um novo mundo na contemplação religiosa do mundo demasiado conhecido.

Mercier e Restif de la Bretonne consideram o Palais-Royal (por algum tempo chamado de Palais Égalité) o lugar prototípico do capitalismo moderno. Ali juntavam-se os negócios de todo o tipo com as diversões, os complôs e o relacionamento humano mais descarado ante o poder da riqueza. A grande roda da fortuna capitalista encontrava-se ali: a bolsa, a prostituição, o jogo, as joalherias, os restaurantes, os salões de moda, os encontros. Ali se flagrava a "santa demagogia", nas palavras de Mercier. Ali se descobria rapidamente esse "surpreendente espírito do homem quando se baseia apenas no interesse pecuniário para todos os seus pensamentos e atividades". Ali se apresentavam as pessoas com a 
fisionomia pronta para "espancar-se, esfaquear-se, devorar-se" mutuamente. Ali Mercier via-se obrigado a aconselhar aos parisienses: "Dançai, suplicovos, dançai, já que é impossível que tenhais outro caráter que vos assente melhor". ${ }^{1}$

Restif procurava os velhos signos do amor em meio a essa selva de negócios e prazeres. O Champ de Mars, a praça do Carroussel, o Panteão e a praça de Greve ou da Prefeitura foram os locais das celebrações do curto tempo da Revolução, o Palais-Royal foi o palco da evolução longa e sustentada do capitalismo.

Em seu Monsieur Nicolas, Restif de la Bretonne se propõe a "desvendar os mecanismos do coração humano". Assim como outros ilustrados, considera que as impressões recebidas durante a infância têm grande importância para a vida posterior do homem. Aborda também a longa infância do homem, durante a qual ele é indefeso. ${ }^{2}$ Sua legitimação do nexo social consiste numa determinada concepção do amor, paralela às de Mercier e Fauchet, com influência do tema da sociabilidade rousseauniana. Esse conceito do amor, juntamente com o da reciprocidade, dão margem a todo um sistema teórico da sociedade, que Restif desenvolve em diferentes pontos de sua obra. Apesar de sua aversão ao iluminismo materialista, Restif admite como seu princípio fundamental:

Sempre amei com delicadeza, e amiúde platonicamente. Ninguém pensou, disse ou fez coisas mais ternas. Mas afinal de contas percebo que a fonte da ternura do coração está nos órgãos do amor físico. Estudando, sempre em mim, o coração humano, que procuro desvendar, tratei de descobrir a causa dos gostos atrozes dos velhos, e a encontrei em sua impotência... Nesta achei o motivo da crueldade das obras tão execráveis que foram escritas desde a Revolução: Justine, Aline, Boudoir, La théorie du libertinage... O velho, corrompido, enfastiado, já não encontrando mais o prazer, pretende não apenas que a mulher tampouco o experimente como também o monstro deseja que sofra, que gema, na razão direta de sua beleza e juventude; e se ela for muito bonita, muito linda, de origem honesta,

${ }^{1}$ MERCIER, L.S., Le Nouveau Paris, Paris, 1798; RESTIF DE LA BRETONNE, N.E., Monsieur Nicolas ou le coeur humain dévoilé, Paris, 1794.

${ }^{2}$ RESTIF DE LA BRETONNE, N.E., op.cit., $t$. I e t. VII, p. 4157. quer que pereça em meio a tormentos. Quanto mais destinada à felicidade estiver, mais quer vê-la desgraçada. ${ }^{3}$

Fora a falta de compreensão política e o reducionismo psicológico da obra de Sade, defeito quase obrigatório em Restif como em tantos outros, essa passagem já evidencia a intenção do "Rousseau du ruisseau", a fé no amor e seu significado em termos de vitalidade, juventude e pureza. Restif suaviza e enaltece tudo que transpira amor, por mais terríveis que possam ser as circunstâncias que o envolvem. Ou melhor, precisamente por essas circunstâncias: a obsessão deste boêmio de Paris é encontrar o amor mais terno e fulgurante em meio às misérias mais sujas e mesquinhas da vida humana. Assim chegará a conhecer e a compartilhar uma parte de sua vida com Zéfire, a prostituta honesta. "Zéfire prostituída era virtuosa, ao passo que muitas mulheres honestas não o são". "Ela considerava o seu estado como legítimo dizia: somos necessárias... Mamãe assegura que assim preservamos as outras mulheres". Sua procura pelo amor escondido na miséria e na desdita não parará até a sua morte. Nisto, mais do que em sua Anti-Justine, Restif se opõe à trajetória sadiana, já que busca Deus através do amor que ele mesmo sente ao contemplar os males, e não por meio da demonstração da providência ante os mesmos males.

Admirando Jesus, Restif abandona o cristianismo devido aos excessos que este comete contra o amor. O paradigma evangélico é para Restif o da relação extremamente humana que acontece entre Jesus e Madalena, relação distorcida pela pregação posterior do cristianismo. Restif não pára de procurar Madalenas ou de sentir o desejo dessa procura. Tal como se configura em Monsieur Nicolas, trata-se de uma integração excepcional do desejo sexual com a paixão religiosa. Ninguém como Restif explora essa dimensão com tanta candura e obstinação.

Como não concorda com o cristianismo, Restif segue suas inclinações em nome do deísmo ${ }^{5}$ :

${ }^{3}$ Idem, op.cit., t. VI, p. 3239.

${ }^{4}$ Idem, op.cit., t. IV, pp. 2054, 2057, 2063, etc; André Burguière (Histoire de la Population Française, Paris, 1988, p. 475) calcula em 30.000 o número das prostitutas de Paris no começo da Revolução. Esta cifra supõe uma proporção dez vezes superior à atual.

${ }^{5}$ RESTIF DE LA BRETONNE, N.E., op.cit., t. IV, p. 2088. 
Creio em um Ser-princípio, fonte de toda vida e de toda inteligência; compensador e vingador já nesta vida. Não creio na imortalidade individual da alma, nem, por conseguinte, num inferno ou num paraíso. Não creio que a homenagem devida à Divindade dependa dos seres que a prestam; ela é física, e não moral, e todos os seres vivos a prestam necessariamente com o exercício natural de suas faculdades. Creio que qualquer Religião diferente desta é falsa: que o cristianismo, sendo contrário à realeza, à nobreza e às riquezas do clero, é uma religião conveniente para os quackers e os jacobinos, que, segundo ela, seriam gente honesta.

Creio que a política inventou a Religião, talvez com boas intenções, e para fortalecer a base do governo: que os primeiros legisladores foram forçados a inventá-la com vistas a educar povos ignorantes e bárbaros. termos ${ }^{6}:$

À lei do amor, Restif une o princípio de Reciprocidade nos seguintes

Vou dizer livremente o que penso: estar com cinquenta e seis anos (escrevo estas linhas em 1790), com os achaques e os sentidos desvanecidos, debilitados por um uso demasiado vivo e frequente, fazem com que já não tema nada nesta vida, nem a morte, que não deixo de contemplar como um dom da Natureza. Vou falar, pois, com franqueza... Aparentemente, a Religião primitiva era de belo feitio. Mas poderíamos dar por certo que nossa espécie atual jamais a professou. Essa primeira Religião tampouco foi descoberta no estado bruto e selvagem da humanidade, embora talvez então se achasse mais próxima: sabemos que todas essas nações antigas adoravam o Sol, a Terra e inclusive a Lua. Mas conjecturo que essa bela e verdadeira Religião, tão simples, tão natural, cuja moral inteira cabia no adágio escrito no fundo de nossos corações: Não faças ao outro o que não queres que te façam... conjecturo, dizia, que esta foi a Religião da Espécie que conquistou o cetro da animalidade, imediatamente antes de nós, na última Revolução do Globo terrestre; Revolução que nossos livros sagrados chamam de começo do mundo. Hoje em dia, quando estamos mais envelhecidos e nossa espécie se aperfeiçoou através de uma longa série de gerações sábias, ilustradas e pensantes, essas mesmas ideias vos tornam a chegar com

${ }^{6}$ Idem, op.cit., t. VII, p. 4156 naturalidade, do modo como haviam alcançado a raça precedente em sua maturidade..

Veis que reconheço um Deus; esta é a base de minha filosofia; que inclusive toleraria um culto moral público, embora inútil, se à Nação lhe parecesse imprescindível.

No entanto ${ }^{8}$ :

A Religião não pode fundamentar a moral: a Reciprocidade não possui os inconvenientes da Religião terrível e ameaçadora, que se tornou inacreditável por causa da atrocidade de suas penas, e cujas recompensas, demasiado acima dos sentidos, não permitem que nenhum desejo se realize. Mas o que aconteceria se à formosa lei da Reciprocidade fosse acrescentada a Religião natural, que nos fraterniza, que só apresenta verdades físicas para a fé, que jamais conseguirá inquietar a Terra, com dogmas absurdos contra os quais a razão se rebela século após século...

A verdadeira base da moral social é a Reciprocidade, que deve ser móvel de todas as nossas ações. É contrário à natureza fazer ao outro o que nos prejudicaria. E, por outro lado, é inconsequente não fazer ao outro o que se ele nos fizesse, nos beneficiaria.

Todas as Religiões são inúteis à felicidade do homem, e insuficientes para dotar com uma base sólida à moral... a única base sólida da moral é o interesse pessoal guiado pela Reciprocidade.

Como consequência desse princípio de Reciprocidade, Restif passa a criticar a instituição que julga mais nociva para a sociabilidade: a propriedade, que ele qualifica de "absurda" e "imoral":

De fato, é como consequência da propriedade, para o seu aumento, que o homem se torna ávido, ambicioso, avaro, duro, fraudulento, ladrão, assassino, em suma, injusto ao extremo. É mediante o excesso de riquezas, acumuladas com esses infames, que pode seduzir, corromper, aviltar e degradar os seus semelhantes de ambos os sexos menos ricos do que ele. Eliminai a propriedade e eliminareis os vícios, embora continuem existindo as paixões. Mas as paixões, quando não vão acompanhadas pela cobiça, jamais produzem vícios

\footnotetext{
${ }^{7}$ Idem, op.cit., t. VII, pp. 4093 e segs.

${ }^{8}$ Idem, op.cit., t. VII, pp. 4176 e 4178.

${ }^{9}$ Idem, op.cit., t. VII, pp. 3985 e 4103-08 e t. VIII, pp. 4324-25.
} 
e muito raramente crimes, já que as paixões, sem a cobiça, só produzem os efeitos da cólera, da vingança e da luxúria. Todas as demais causas dos crimes se acham ausentes. No entanto, com boas leis capazes de não tolerar nenhuma injustiça, os efeitos da cólera ficariam muito limitados. Jamais se chegaria à vingança porque a lei asseguraria a repressão de qualquer abuso ou mau procedimento... $\mathrm{E}$ ante a luxúria o comunismo aniquila toda sedução ou corrupção com dinheiro.

Esse comunismo que Restif propunha consistia na observância de um "Regulamento proposto a toda a Europa e aos demais países com habitantes europeus para estabelecer uma Comunidade geral do gênero humano". Em 29 artigos garantia-se, entre outras coisas, a distribuição equitativa de terras e trabalho, bem como o uso do dinheiro apenas para "recompensas morais".

A propriedade e a religião estabelecida (cristã) passam então a ser imorais e, apesar da filantropia, tampouco se deve confiar no povo: “... a versatilidade do povo, este ser-coletivo sempre injusto e desprezível". ${ }^{10}$ Contudo, a sociedade comunista merece uma reflexão por parte de Restif, já que ele considera a propriedade como a origem do $\mathrm{mal}^{11}$ : por ser "abominável, execrável, insolente e desgraçada":

Já sei que é inútil pregar o Comunismo aos homens: demasiadas paixões se interpõem a isso! Os cabeças do gênero humano, os egoístas, os ricos, todos os viciosos têm muito interesse em obstaculizá-lo, para que nunca possa ser realizado! Nem um Deus o estabeleceria;... o poderoso Jeová, que fez dele um Preceito (embora os falsos cristãos digam que se trata apenas de um conselho), não pôde, em toda a Sua glória, estabelecer esse santo comunismo: e eu, inseto que se arrasta no pó, eu o estabeleceria?!. Se um Deus o estabelecesse, seria bendito por isso: mas no princípio só escutaria maldições... É preciso ouvir os ricos, sobretudo os novos ricos, os exnobres, os ex-beneficiários, que chamam a si mesmos tão escandalosamente de cristãos, falar de sua anticristã, imoral, apóstata e atroz propriedade! Ousam dizer-vos que os homens se uniram em sociedade para manter, para conservar sua propriedade! Demonstrei, em minha Moral, que isso era afirmar um absurdo.

\footnotetext{
${ }^{10}$ Idem, op.cit., t. VIII, pp. 4328, 4214 e 4363.
}

${ }^{11}$ Idem, op.cit., t. VIII, pp. 4385-86 e t. VI, p. 3982.
Odiosos economistas! Ó vós que haveis falseado o julgamento do gênero humano sobre a imoral propriedade erguendo algumas verdades perigosas em cima do mais execrável dos princípios. Haveis colocado como princípio um abuso, como base da sociabilidade, a propriedade individual absoluta! Haveis partido daí E que consequências tão repugnantes tirastes disso? Que ao pretenso proprietário cabia decidir o preço que quisesse pedir por suas coisas que podia perdê-las, destroçá-las, levá-las para o exterior, sem preocupar-se com a escassez, com as necessidades de seus concidadãos, com sua pobreza! Ó Monstros! Aprendei comigo, que talvez desprezeis, mas que vos fulmino; aprendei que o direito sagrado da natureza opõe-se diametralmente a vossa impolítica, a vossa despótica e destrutiva propriedade! A mãe de todos os vícios não é a preguiça, mas a propriedade!

Esse pensamento apresenta influências de autores do século XVII e inclusive premonições do XIX. Restif é porta-voz de uma opinião que ele mesmo aborda a meio caminho entre Rousseau e Roux. Juntamente com o racionalismo econômico, Restif despreza também o nascente formalismo científico que considera traidor do desenvolvimento espiritual e moral do ser humano ${ }^{12}$ :

É o abuso do conhecimento material das leis do movimento dos Cometas, dos Planetas, etc., conhecimento maquinal e limitado, que impede Lalande de chegar ao Ser-princípio: assim como uma criança que só se dá conta das segundas ou terceiras causas, e possui um espírito pesado demais para ir mais acima. Foi o conhecimento

${ }^{12}$ Idem, op.cit., t.VIII, p. 4824 e t. IV, pp. 2130 e 3306.

Mercier desconfiava dos planos de educação democrática que a Revolução e a pós-revolução defendiam: "Se nos descuidarmos, o professorado vai substituir entre nós o sacerdócio e tornar a criar uma multidão de homens cheios de verborragia, pretensões, trapaças e misérias, bem remunerados e perfeitamente inúteis".

Ao considerar o ensino de matérias sobre o entendimento humano, a legislação, a história, a moral e a economia política, ele afirma: "Essas matérias, que tocam tão de perto zonas profundamente obscuras, não podem ser ensinadas; o homem que tiver nascido para estes conhecimentos os alcançará por si mesmo, e neste tipo de saber a orientação atrapalha e degenera muito mais o espírito do que o eleva.

Assim, depois de tantos professores, ainda querem professores de línguas estrangeiras? Línguas estrangeiras! Eu acreditava que só havia uma língua na Europa, a dos republicanos franceses ... Inclusive, antes da revolução só nos respondiam em francês, da foz do Tejo à do Neva". (MERCIER, L.S., Le Nouveau Paris, Paris, 1798, art. "Professorat".) 
material e maquinal das leis do movimento que impediu Simon Laplace de conceber a beleza, a verdade ou ao menos a verossimilhança de minhas hipóteses Calculadores, Geômetras, Astrônomos, Cifrômanos e não filósofos limitados, nulos...

Restif, deísta, rousseauniano, devoto do amor às mulheres infelizes e marginalizadas, consolado pelo desespero, arrebatado pelas causas da "versatilidade do povo", autor de um hino à pobreza, reformador dos costumes, etnógrafo da ilha de Saint-Louis, relacionado com a polícia, escarnecido pelas crianças, maltratado publicamente, lido com avidez; Restif, a quem só se chega depois de penetrar na atmosfera particular de suas milhares de páginas escritas, exemplifica a sensibilidade de outra época. Sua forma de ver, tratar, amar e atacar é impossível de traduzir o presente sem cair numa caricatura ridícula ou numa miscelânea pitoresca. Compreender Restif é compreender toda uma sensibilidade do Iluminismo: como se coloca o amor, a sociabilidade, a religião, a vida material e os valores em geral. Assim começa a narrar os acontecimentos de um ano: "em 1780, eu tinha quarenta e seis anos e amei! Amei!"

Em 1788, Mercier publica seus Sonhos e visões filosóficas. Neles nos expõe algumas chaves da relação entre a religiosidade, a filosofia e a política, que serão muito significativas para a Revolução. Chaves que são o ponto de chegada de formulações herdadas de vários iluministas anteriores.

Assim acontece com a reflexão sobre Maomé, ideia fundamental para a articulação do pensamento de boa parte dos iluministas e líderes revolucionários acerca do vínculo entre a política e a religião ${ }^{13}$ :

Não acuses um grande homem que foi reverenciado por boa parte do mundo e foi capaz de destruir a idolatria. Sabes ler o que escreveu? A calúnia poética subiu ao palco de uma nação e imputou a seu personagem crimes imaginários; mas é capaz de ir contra o respeito universal dos povos e contra seu antigo reconhecimento? Falamos de preceitos ainda vivos e disseminados numa superfície considerável do globo, baseados em grandes e esclarecedoras origens. Sim, foi um legislador que, sentindo que o homem sempre repeliria a autoridade do próprio homem, seu igual e semelhante, fez com que descessem

${ }^{13}$ MERCIER, L.S., Songes et visions philosophiques, Amsterdã-Paris, 1788. Sonho IX, p.159 do céu as ordens que quis fazer cumprir na terra. Guarda-te de repreendê-lo por isto; guarda-te de acusá-lo de embusteiro ou de impostor, por existirem leis sábias e úteis que são a expressão da vontade divina, já que não é prejudicial ao homem ser persuadido de seus verdadeiros deveres; já que o mundo inteiro, apresentando a convicção de que um poder superior estabeleceu as leis morais e físicas, faz com que o homem de grande visão se torne seu porta-voz, intérprete abalizado dessas leis divinas. E assim, as revelam com um tom apropriado a sua majestade; outorga uma base religiosa à política civil, uma base sagrada e necessária; o direito fica então adequado à nobreza e à pureza de suas causas.

Se os antigos legisladores misturaram fábulas e fantasias a verdades importantes e sublimes, foi porque este era o único meio de introduzi-las. Os tempos, as circunstâncias, o espírito humano, sempre apegado ao maravilhoso, tudo contribuiu para forçar o legislador a amalgamar o culto com os costumes morais: estes eram a alma para sua política e aquele era o corpo suscetível de ser influenciado sem perigo.

Colocaríeis, observadores de visão míope e estreita, colocaríeis, com patente ingratidão, os benfeitores esclarecidos do gênero humano entre os impostores, por terem se compadecido das fraquezas deste e ter-lhes deixado alguns de seus inevitáveis erros para obter algumas novas luzes e virtudes?

Estes erros não foram obras deles, mas, anteriormente a eles, de uma multidão que transitava às cegas: uma religião puramente metafísica não teria sido então nem escutada nem compreendida, e tampouco o seria hoje em dia.

Sede mais justos, frágeis humanos; dai graças aos que pela primeira vez ensinaram a ideia de Divindade, que é testemunha de todas as nossas ações e deve castigá-las ou recompensá-las, aos que instituíram as festas que reúnem os homens; aos que proibiram o crime, o roubo e a injustiça..

Seria difícil, inclusive atualmente, decidir até que ponto um homem que desejasse transmitir suas opiniões ao espírito de um povo novo poderia lançar mão do entusiasmo e do maravilhoso. O caminho seria longo e incerto se procedesse unicamente com os meios da convicção; mas se procurasse impressionar com força a imaginação, causaria imediatamente uma revolução útil. E, dizei-me quem hoje 
não perdoaria o legislador moderno por algum engodo inocente que tivesse conseguido fazer um povo ignorante, supersticioso e bárbaro adotar leis sábias, razoáveis e benfazejas?

Por um lado, portanto, Mercier estabelece um deísmo político onde a força convencional da obrigação religiosa legitima o próprio dogma deísta. Mas, indo além das observações feitas sobre Maquiavel, Montesquieu e seus seguidores, Mercier quer contentar mais o deísmo religioso ou sua própria necessidade de um Deus. Desta maneira, alicerça a base ou a razão de ser da sociedade na própria razão de ser da religião: se há sociedade é porque Deus existe. Aquele que não reconhece Deus, tampouco pode reconhecer a sociedade. O ateu é um homem só ${ }^{14}$ :

Quanto mais templos uma religião construir, mais próxima de sua queda se encontrará. Um único templo basta para uma cidade, conservando assim com mais cuidado toda essa pompa misteriosa que se impõe à imaginação. Esses gastos tão vultosos com os edifícios sagrados sempre me pareceram faustosos e onerosos para o povo, que ordinariamente arcava com os custos. E assim mesmo esses templos, depois de meio século de construção, ainda não estavam terminados. Deveria haver menos templos, mais simples, e então o fervor religioso aumentaria.

Dar aos homens o freio da religião constitui uma instituição admirável. Mais admirável ainda, porém, é saber adaptar o dogma e o culto à reforma dos vícios particulares de uma nação. Isto seria a obra-prima de um bom legislador de religião.

O culto interior é a homenagem que toda criatura deve prestar ao Ser Supremo. É o culto por excelência. É o que é digno de ser oferecido a quem é espírito e verdade. Mas como o homem não está isolado, deve reconhecê-lo publicamente.

O interesse do gênero humano exige que um Deus seja reconhecido e adorado.

Eu condenaria um ateu a viver só. O que é um ateu? É um homem que se isolou, que fez de si o centro do universo, que já não pode ter desejos elevados nem esperanças consoladoras: é um egoísta que

\footnotetext{
${ }^{14}$ Idem, op. cit., sonho XXIX, p. 212 (LII).
}

destruiu um ser supremo para converter-se a si mesmo no ser por excelência. Deverá acabar vivendo só, e assim será um dia, já que o inferno será estar só, só. Esta ideia faz estremecer.

Os crimes cometidos pelos fanáticos não geram remorsos em sua consciência. Dormem tranquilos com seus delitos, sua consciência não lhes diz nada; foi em vão que ultrajaram a natureza. A religião que acreditam ter vingado assegura uma paz tão sórdida quanto segura para o seu coração. Não é este o sentimento mais horrível que é capaz de desnaturar o coração do homem?

Todas as ideias morais acabam expirando nas garras do frenesi religioso. O fanático agride cegamente, ele é um monstro enquanto ser...

O destino do mau é a solidão... O inferno é isso; não é em vão que todo o seu ser se agita. Ali o mau está só. Estar só é seu suplício: não foi capaz de ver seu semelhante e seu semelhante já não o vê: só teve ideias pessoais. Vivendo sempre com suas ideias estreitas, tornou-se o seu próprio verdugo; não conheceu a compaixão doce e enternecedora, tomando frio seu coração. Jamais o entusiasmo generoso mostrou-lhe todos os homens como um povo de irmãos, pois viveu sempre separado deles. Longe da amável alegria, não foi bom, ficou esquecido pelo universo e está só. Já não percebe os mundos e os sóis criados pelo Ser Todo-poderoso: ainda sente a criação, mas já não vive para ela; está longe dela, fora dela, vive com a alma dura e perversa; tampouco poderia dedicar-se a sua contemplação, pois a detesta; desejaria aniquilá-la e não pode, eis aqui o inferno.

Os ideais de Mercier são a Religião, a Humanidade e a Honestidade: "Estas imagens são a obra-prima do espírito humano; suas origens encontram-se nos céus". ${ }^{16}$

${ }^{15}$ Idem, op. cit., sonho LV. O mau, assim como o ateu, é condenado à solidão. O primeiro por não saber ver aos seus semelhantes, o segundo por não saber ver a Deus, o único que nos ensina a ver nossos semelhantes. Ó ateu não acredita na sociedade, o fanático a desfigura, o político sem a fé religiosa também está só, é um ditador. A marcha da sociedade depende dessa religiosidade que a cimenta e eleva. Mercier, com seu grande antecessor, Mably, prenuncia os discursos de Robespierre.

${ }^{16}$ Idem, op. cit., sonho XIII. 
A inclusão do estético no gesto e na emoção religiosos, que artistas como David acentuaram ao máximo em sua concepção da religiosidade revolucionária, em breve se faria sentir como necessidade no próprio cristianismo. Chateaubriand desenvolveria mais extensamente o tema. Se o cristianismo podia concordar com a filosofia e com a revolução, ficando inclusive à testa das mesmas, em nome da liberdade e da melhora da humanidade, depois da lição pagã da Revolução tão criticada por muitos católicos, a estética devolvida ao coração da religiosidade é que levaria o cristianismo a uma nova imagem. Era preciso mostrar, provar mais além do que fora dito pelos rousseaunianos, que a religião era bela, que suas máximas e exemplos se entrosavam perfeitamente com os ideais e emoções da estética, da estética de um mundo preferentemente clássico.

\section{Chateaubriand $^{17}$ :}

O Redentor nasceu de uma virgem para que aprendêssemos que, por motivos políticos e naturais, a terra já atingira o seu máximo de habitantes, e que ao invés de multiplicar as gerações seria preciso restringi-las a partir de então; que os Estados nunca perecem por falta mas por excesso de povoadores... Considerada de outras perspectivas, a virgindade não é menos agradável. Nos três reinos da natureza, é a fonte das graças e a perfeição da beleza. Os poetas, a quem mais queremos convencer aqui, nos servirão de autoridade contra suas próprias afirmações. Não se comprazem em reproduzir por toda parte a ideia de que a virgindade é um encanto para suas descrições e quadros? É assim que a encontram no meio dos campos, nas rosas da primavera e na neve do inverno; é assim que a colocam nos dois extremos da vida, nos lábios da criança e nos cabelos do ancião; ainda é mesclada aos mistérios da morte, e nos recordam aquele período que dedicava aos manes as árvores sem sementes, porque a morte é estéril, ou porque na outra vida os sexos não são reconhecidos e a alma é uma virgem imortal.

M.-J. Chénier censura em Chateaubriand a tentativa de confundir boa parte da sensibilidade pagã com o cristianismo. ${ }^{18}$ Chénier considera que, por exemplo, o conceito pagão de fatalidade não tem paralelo no cristianismo, e que apenas o teatro moderno tentou conservá-lo. Chénier estava certamente

${ }^{17}$ CHÉNIER, M.-I., “Chateaubriand”, em Les Nouveaux Saints, Paris, 1801, p.15.

${ }^{18}$ Idem, op. cit., p. 35 . fazendo eco às ideias de d'Holbach acerca do fatalismo. Ante essas ideias, o cristianismo não pode captar algo cujos dogmas, que sempre tendem à transcendência, ignoram.

Lacretelle também criticou Chateaubriand por sua tentativa de domesticação da filosofia estética em benefício do cristianismo, ao passo que o abade Morellet, antecipando o modo de sentir de muitos católicos pouco amigos do Iluminismo, disse que a verdadeira religião não precisava desse gênero de apologias e que seu próprio conteúdo superava todas elas. Tal argumento chegou ao auge com o abade Sicard, ao afirmar que o gênio de uma instituição é aquilo que lhe é mais próprio. Dessa maneira, o cristianismo não existe para fazer poesia nem para estimular as artes, mas para obter a graça de Deus mediante uma vida virtuosa que acarreta privações tais que a pessoa não é capaz de se dedicar a desvarios estéticos. ${ }^{19}$

Aos olhos do cristianismo mais ascético, Chateaubriand apenas tenta recuperar a estética pagã (tentativa frustrada, para os neoclássicos) para colocá-la a serviço de um cristianismo que, assim, chega a parecer mais ocioso e frívolo aos olhos dos ascetas.
${ }^{19}$ Idem, pp. 44-45,77, 121, 127 e 149. 


\section{A ilusão de Saint-Pierre}

A concepção moral da ciência, de parcial inspiração rousseauniana, teria seus pontos altos e baixos durante a Revolução. Como também na Alemanha e na Inglaterra, vários estudiosos acreditavam que o conhecimento científico do mundo era próprio de pessoas sensibilizadas pela percepção moral e estética do mesmo. Assim, a poesia ou a prosa poética deviam forçosamente acompanhar o conhecimento mais íntimo da natureza. As metáforas entre o mundo moral e o natural, as imagens emotivas que determinadas interpretações da natureza podiam proporcionar, e um deísmo carregado de expressões panteístas caracterizavam essa corrente, cujo principal representante francês foi Bernardin de Saint Pierre.

Durante a revolução houve também uma contribuição no mesmo sentido que conquistou, em princípio, um maior beneplácito das elites revolucionárias do período convencional do que as de um Lavoisier ou de um Condorcet à ciência. É o caso dos "Ensaios de Botânica Moral", publicados na Décade Philosophique, que constituem uma das mesclas mais originais de geografia humana e estética com traços de contemplação da natureza.

Bernardin de Saint-Pierre tentara responder sistematicamente, desenvolvendo os argumentos de Rousseau, às queixas que Voltaire suscitara contra a Divina Providência e que haviam dado lugar a um debate bastante generalizado sobre o mal. ${ }^{2}$ Depois, com uma ideia minuciosamente otimista da natureza, Saint-Pierre procura estabelecer em sua obra Harmonies de la Nature uma ciência moral concordante com outras iniciativas paralelas da ciência romântica: se podemos perceber a natureza como boa, os princípios da moral do bem devem coincidir com as leis naturais, podendo assim construir um conhecimento científico a partir de analogias morais entre os elementos naturais. Em outras palavras, a linguagem da ética seria a linguagem "formal" da ciência da natureza, sendo as teorias éticas coincidentes com outras teorias científicas. Se o

${ }^{1}$ La Décade Philophique, littéraire et politique, Paris, 1793-94, $\mathrm{n}^{\circ} 7$.

${ }^{2}$ SAINT-PIERRE, Jacques Henri Bernardin de, Oeuvres, Paris, 1840. Étudés sur la Nature (1784), estudo $\mathrm{n}^{\circ}$ 7. Harmonies de la Nature, 2 v. (1814). Études sur la Nature, op.cit., estudos $\mathrm{n}^{\circ} 1$ e 8 . sentimento moral era o mais natural e profundo no homem, devia ser o mais adequado ao conhecimento real das coisas. Igual juízo faziam alguns artistas ingleses e alemães em virtude da estética vista como percepção mais intensa da natureza e, portanto, com mais autoridade para pregar a seu respeito.

Nessas analogias morais, Saint-Pierre estabelecia toda uma religiosidade (sugestiva de sentimentos panteístas) enquanto linguagem da pesquisa da natureza. Esse esforço coincidirá com outro de signo contrário durante a Revolução: o de geômetras, matemáticos e engenheiros que desenvolveram notavelmente a linguagem formal algébrica. Saint-Pierre é o canto do cisne de uma possibilidade ilusória da humanidade: a de condicionar o conhecimento das coisas reais à atitude moral diante da vida. Um condicionamento repleto de religiosidade. 


\section{A apoteose de Rousseau}

Gobel e Soboul ${ }^{1}$ ressaltaram a difusão das ideias de Jean-Jacques sobre a vida humana no transcurso da Revolução Francesa. As edições de suas obras e as contínuas referências - políticas, literárias e filosóficas - a sua pessoa e as suas atitudes evidenciam a importância do pensador, que não era francês de origem, para a França que se afirmava como república e como democracia.

Talvez em virtude de tudo que Jean-Jacques Rousseau representava, sua apoteose se fez esperar. Parecia que não podia entrar no Panteão antes que os signos convencionais do aristocratismo e da demagogia, Mirabeau e Marat, o tivessem deixado. Assim, Rousseau entra no Panteão em onze de outubro de 1794, quando a companhia que o espera na antiga basílica de Ste. Geneviève é a de Descartes e de Voltaire. ${ }^{2}$

Não há um único coração sensível que tenha podido esquecer as delícias daquela bela tarde de outono em que os habitantes de Ermenonville trouxeram para Paris o sepulcro do autor do Emílio sob um dossel de flores e arbustos.

O ar estava calmo, o céu, puro; uma ampla tela de púrpura velava os raios do sol que descansava no horizonte; as últimas folhas agitavamse levemente com uma brisa suave.

O som de uma música simples logo é ouvido ao longe. Uma multidão de cidadãos precipita-se diante do cortejo. Todos os corações palpitam de alegria.

O carro fúnebre entrava com lentidão majestosa. Uma juventude numerosa seguia-o em respeitoso silêncio.

Os músicos deixavam curtos intervalos entre suas melodias, a fim de que cada um as pudesse repetir para si mesmo.

Eram as apreciadas melodias do Homem da Natureza, as que a cada dia o amante repete a sua amada, a terna esposa ao seu feliz esposo.

${ }^{1}$ GOBEL, G., SOBOUL, A., "Audience et Pragmatisme du Rousseauisme", em A.H.R.F., n ${ }^{\circ}$ 234, 1978.

${ }^{2}$ Cf. HENRIQUEZ, L.M., La Dépanthéonisation de J.P. MARAT, Paris, s.d.
Dir-se-ia que os anjos, tendo descido à terra, estavam prestes a leválo para o céu em meio a seus maravilhosos concertos.

O féretro chegou ao espelho d'água que representava a Ilha dos Álamos. Ali recebeu as lágrimas dos espectadores que lotavam seus arredores, especialmente as das mulheres, que pensavam em Julie, em Sophie, na Sra. de Warens, tão terna e constantemente amada por seu filho adotivo.

O sepulcro foi depositado num estrado e coberto com um pano azul salpicado de estrelas.

Todos os olhares se concentraram ali. A glória do grande homem atravessava as trevas da morte e parecia mostrá-lo vivo de novo.

Mil tochas iluminavam esta emocionante cerimônia. As lágrimas embelezavam todos os rostos. Não exibiam a imagem da dor inconsolável pela perda de um amigo, mas a tranquila esperança de tornar a vê-lo.

As exéquias foram encerradas cantando-se "Em minha cabana escura" e, ao retirarem-se para suas casas, todos ainda a cantavam com ternura.

Foi Lakanal o intérprete responsável pelo significado da cerimônia ${ }^{4}$ :

Cidadão, haveis decidido conceder as honras do Panteão a J.-J. Rousseau e erigir-lhe uma estátua.

Vosso comitê de instrução pública encarregou-me de vos submeter suas opiniões sobre este ato solene de justiça nacional, solicitado pela influência cotidiana do filósofo de Genebra no progresso da moral pública e por esta fama sempre crescente que acabaria voltando-se contra vós se tardásseis em dar-lhe seu último esplendor, abrindo ao autor do Contrato Social e do Emílio as portas do Panteão francês.

No momento em que um povo inteiro, cansado de uma escravidão muito longa, é empurrado para a liberdade pelos excessos do despotismo; em que se debate entre grilhões, só precisando para rompê-los de um movimento enérgico e rápido; quando agitando-se em todos os sentidos, procurando a saída que seus velhos hábitos lhe

3 . MERCIER, L.S., Le Nouveau Paris, Paris, 1798, capítulo "J.-J. Rousseau aux Tuileries". ${ }^{4}$ LAKANAL, Joseph, Rapport sur J.J. Rousseau, faint au nom du Comité d'Instruction Publique, 29 do frutidor, ano II (15-IX-1794). 
ocultam, tendo apenas sentimentos confusos sobre seus direitos, sem encontrar, por sua excessiva servidão, uma linguagem adequada que faça empalidecer a tirania e impulsione o escravo a se libertar... E se no meio deste povo se ergue um homem de gênio efervescente, apaixonado, audaz, um homem cuja eloquência viril, cuja voz, cujos movimentos impetuosos, cujo rosto destacado, embora por sua fealdade, impressionam os olhares, atraem a atenção e se gravam na memória; se este homem se lança na corrente das primeiras agitações populares, se, quando a revolução entra em ebulição, ele a precipita e dirige seu curso, sua ideia se funde com a da própria revolução; ele então sozinho já é um poder, ele sozinho constitui uma dessas causas ativas e terríveis cuja ação constante muda a face dos impérios; e o povo, liberto de seu jugo, acreditando sê-lo graças a ele, aplaude-o, glorifica-o com suas exéquias, dedica-lhe triunfos inusitados e novas apoteoses.

Mas desde o instante em que já não existe; quando seus meios de sedução e seu prestígio pessoal já se desvaneceram; em que o curso das coisas arrasaram suas circunstâncias, aquelas que lhe granjeavam fama e influência; se além disto descobre-se então que esse homem se vendeu a outros interesses que não os do povo, que foi partidário secreto, cúmplice do trono e instrumento da tirania; se em lugar de seus talentos e virtudes, agora imaginários e aviltados, são descobertos seus vícios, intrigas, imoralidades e corrupções, então o povo indignado ergue-se contra sua memória, e numa vingança justa derruba os monumentos edificados por um reconhecimento cego; e o ídolo, arrancado do santuário, é quebrado e pisoteado com todo desprezo.

Não é de se temer que tal sorte aguarda esse grande homem que ides homenagear. Recordei que se encontrava só, sem apoio, sem protetores, quando se atreveu a erguer-se em meio a um povo adormecido em seus grilhões, contra o despotismo, proclamando a ciência e a liberdade. Num tempo em que todas as homenagens eram prestadas ao berço, às grandezas, às riquezas, atacou a todos esses velhos preconceitos e proclamou a igualdade natural; colocando em seu devido lugar, quer dizer, no vazio, os títulos de nobreza: atacou frontalmente os favoritos, lançou sobre a culposa e estúpida opulência todo o desprezo da sabedoria e toda a indignação da virtude. Fez mais ainda: tirou as profissões úteis de um esquecimento injusto e aviltante; ensinou-nos a honrar o trabalho, a pobreza e a desgraça, a procurar na humilde oficina ou na obscura choça as virtudes, os bons costumes, a verdadeira dignidade, bem como a verdadeira felicidade; numa palavra, a desprezar tudo que a insânia e a corrupção dos homens deificava, e a cobrir de consideração e de estima o que seu louco orgulho desprezava.

Sua alma só respirava para a liberdade dos homens, e isto o fez um estrangeiro entre seus contemporâneos. Quis forçá-los a conhecer-se: haviam-se aviltado tanto ante seus tiranos que não podiam castigálos. Pobre, errante, perseguido em Genebra, sua pátria, expulso de duas ilhas inóspitas onde queria ocultar-se junto com seu renome, fugindo da França por entre as labaredas que queimavam suas obras, não encontrando senão patíbulos nos países dos reis, deve agora ter altares entre os povos livres.

Se as homenagens que lhes são finalmente prestadas são tardias, não importa, serão mais duradouras; nenhuma mudança de opinião deve ser temida quanto a ele. A voz dos povos que solicitam a sua glória é a voz de toda a posteridade.

Todos os escritores que analisaram J.-J. Rousseau no contexto da Revolução Francesa destacaram sobretudo a influência do Contrato Social e de seus outros escritos políticos.

Mas as grandes máximas desenvolvidas no Contrato Social, tão evidentes, tão simples que parecem atuais, surtiram à época muito pouco efeito: não foram escutadas para serem aproveitadas ou temidas; estavam por demais acima do alcance do comum dos espíritos, inclusive do alcance dos que eram ou pensavam ser superiores aos espíritos vulgares. Foi a própria revolução que, de certa forma, nos explicou o Contrato Social. Era outra obra que iria nos levar à revolução, nos instruir, nos elevar e fazer com que nos entrosássemos com ela: Emílio, o único código de educação aprovado pela natureza.

O simples nome dessa obra lembra inúmeros grandes serviços prestados à humanidade: a infância liberta das amarras bárbaras que a deformavam e da instrução servil que a embrutecia; o método da razão substituindo os dos preconceitos e da rotina; o ensino transformado em mais prazeroso para quem o recebe, e o caminho da virtude aplainado como o da ciência; as mães, até então perdidas pela dissipação do mundo, chamadas por fim perante o tribunal da natureza e conduzidas, por meio de uma irresistível eloquência e da atração do prazer, ao mais doce e sagrado de seus deveres. Inúmeros 
escritores já demonstraram, antes de Jean-Jacques, que as mães deviam alimentar seus filhos; mas Rousseau, disse um célebre naturalista, fez-se obedecer.

Isso já era uma revolução imensa para nossas instituições e costumes, mas além disto, nesse mesmo livro, o povo e os tiranos, os ricos e os pobres, as artes do luxo e as artes úteis estavam tão bem colocados em seus lugares, estavam tão bem substituídos os desvarios de um regime absurdo, feito somente para escravos, por todos os princípios de um regime sábio e digno do homem, que ou bem se abandonava a leitura do livro, algo que o estilo extremamente atraente tornava muito difícil, ou inclusive, apesar de si mesmo, aceitava-se esse alimento fecundo de uma próxima regeneração.

Não esquecemos de que nos incumbistes de um exame, não de um panegírico. Não esquecemos de que Rousseau responsabilizou as ciências por uma parte dos males que afligiram a espécie humana. Poder-se-á dizer que um escritor que apoia semelhantes paradoxos não tem o direito à gratidão dos povos livres. Ingratos! Ignorais por que ele disse isso! O abuso que tão frequentemente fizestes da ciência foi tão funesto para os homens que, na alienação de sua dor, teria desejado devolvê-los à ignorância e ao estado selvagem: respeitai esse delírio feliz, tê-lo é próprio do amigo da humanidade. J.-J. Rousseau atacou as ciências, mas suas obras provam o quanto se ocupou delas. Não, não são contrárias à felicidade dos povos: são elas que podem tirar o homem de suas desgraças, elas consolaram Boécio em sua prisão... Elas purificam as almas de seus fiéis seguidores: quantos homens lhes devem suas virtudes e prazeres! São elas que iluminam terrivelmente os princípios violados: o homem que pensa não sabe ser escravo.

A inveja ao talento superior sempre se vingou do caráter da pessoa: podia evitar que assim fosse com um escritor famoso em toda a Europa? Visitei com recolhimento religioso o vale solitário onde este grande homem passou os últimos anos de sua vida; vivi vários dias entre esses plácidos agricultores que ele frequentemente considerava com todo o desprendimento característico da verdadeira amizade; era muito triste, diziam-me, mas era muito bom! Procurei a verdade na boca dos homens próximos à natureza.

Vosso comitê deliberou sobre o caráter que se poderia dar a este funeral solene: achou conveniente rememorar os diferentes títulos que valeram o reconhecimento público a J.-J. Rousseau.
A música que cultivou e que, por assim dizer, devolveu a sua primitiva inocência; a botânica, da qual fez um estudo ameno e consolador; as artes mecânicas, que fez respeitar; os direitos do homem, que foi o primeiro a reivindicar; as mães e os filhos que, de certo modo, devolveu aos braços da natureza; o povo, que ele ajudou a tornar livre, representado por nossos irmãos de Paris; a República de Genebra, que por fim se vingou dos ultrajes de seus aristocratas à memória de Rousseau, representada pelo enviado desta República e pelos patriotas de Genebra radicados em Paris; os habitantes de Ermenonville, que por muito tempo abrigaram seus restos mortais; os cidadãos das comunas de Grolet e Montmorency, que viram nasce entre eles as mais belas obras de seu amigo e que foram os primeiros a erguer-lhe um monumento bucólico; por fim, a Convenção Nacional: tal nos pareceu a melhor composição geral do cortejo.

Mas pareceu-nos que o monumento dedicado a J.-J. Rousseau, ao amigo do campo e da natureza, só devia ser colocado no templo dos grandes homens provisoriamente. Se o desejo dos amigos das artes for satisfeito, esse templo não permanecerá isolado no meio do imenso terreno que o circunda; há tempos se propôs envolvê-lo com uma vasta plantação de árvores, cuja silenciosa sombra aumentaria o sentimento religioso que o monumento funerário inspira. Seria fáci proporcionar a esse augusto bosque um perímetro de álamos em algum lugar, no meio do qual seria definitivamente instalado o monumento dedicado ao autor de Emílio: em sua morte, parece que a ideia dessa árvore melancólica é inseparável de sua tumba; e esse espetáculo enternecedor recordaria para sempre às almas sensíveis a lembrança dos pequenos bosques de Ermenonville.

Eis o plano da festa:

O cortejo será composto por: primeiro um grupo de músicos executando as melodias de $O$ Adivinho da Aldeia e outras mais de autoria de J.-J. Rousseau.

O segundo grupo seria de botânicos com feixes de plantas. Inscrição: $\mathrm{O}$ estudo da natureza o consolava das injustiças dos homens. O terceiro, de artistas de todo tipo com os instrumentos de seu ofício. Inscrição: Reabilitou as artes úteis. O quarto grupo, de deputados das seções de Paris com as tábuas dos direitos do homem à frente. Inscrição: Foi o primeiro a reivindicar esses direitos inalienáveis Uma estátua da Liberdade. Quinto grupo, mães vestidas à moda antiga: umas conduzindo pela mão crianças que já podem 
acompanhar o cortejo, outras carregando em seus braços os mais pequeninos. Inscrição: Uniu as mães aos seus deveres e as crianças à felicidade. Uma estátua de Rousseau, com esta inscrição: Em nome do povo francês, A Convenção Nacional, a J.-J. Rousseau, ano II da República. Sexto grupo, habitantes de Franciade e das comunas de Grolet e Montmorency. Inscrição: Entre nós escreveu A Nova Heloísa, Emílio e $O$ Contrato Social. Sétimo grupo: habitantes da comuna de Ermenonville, circundando a uma cinerária, onde serão gravadas estas palavras: Aqui repousa o amigo da natureza e da verdade. O oitavo grupo será composto de genebreses ao lado do emissário da República. Inscrição. Genebra aristocrática o proscreveu, Genebra regenerada vingou sua memória. O nono: a Convenção Nacional, circundada por uma faixa tricolor e precedida pelo farol dos legisladores, $O$ Contrato Social.

Além de Lakanai, a cerimônia e sua justificação foram articuladas por Boissy d'Anglas, Thibaudeau, Grégoire, M.-J.Chénier, Lindet e Lequinio, entre outros. A apoteose de Rousseau não estava, de modo algum, contradizendo os motivos que inspiraram a de Voltaire, ao contrário, pois foi enfatizado o Rousseau político e moralista, mais próximo ao Voltaire que também foi destacado, tolerante e amante da liberdade. Não é apresentado o Rousseau oposto aos philosophes e ao pedantismo iluminista, como tampouco foi exibido o Voltaire impaciente e mordaz com a sensibilidade rousseauniana. $\mathrm{O}$ oposto de Rousseau nesse caso não é Voltaire, mas Mirabeau, o aristocrata condescendente, elitista - que negociava com a revolução e a nobreza. Também flutuavam os excessos de Robespierre, por outro lado grande admirador de Rousseau, precisamente por sua oposição ao iluminismo materialista e complacente com as elites.

O que a cerimônia destaca, talvez um pouco mais do que as outras apoteoses, é a celebração das circunstâncias próprias da paz, mais do que as do heroísmo ou da coragem diante da guerra e da opressão. Isto poderia ser facilmente relacionado a uma Convenção pós-robespierrista ainda jacobina, porém substituindo em maior grau a militância ativa e agressiva por um esforço de reconciliação, apresentando mais a revolução na linguagem dos direitos humanos do que na da intransigência e do purismo de uma república de soldados e legisladores. Por outro lado, Rousseau reforça esse espírito mais pacífico com a sensibilidade tão suave de sua obra e com a aura que dela Girardin soube manter na ilha dos álamos italianos.
A apoteose de Rousseau foi coroada pelo seguinte discurso do presidente da Convenção:

Cidadãos, as honras do Panteão, oferecidas aos manes de Rousseau, são uma homenagem que a nação presta às virtudes, aos talentos e ao gênio.

Se tivesse sido apenas o homem mais eloquente de seu século, teríamos deixado ao renome o cuidado de celebrá-lo; mas ele fez mais, honrou a humanidade, estendeu o império da razão e da moral. Eis aqui sua glória e seus direitos para que os reconheçamos.

Moralista profundo, apóstolo da liberdade e da igualdade, foi o precursor que chamou a nação ao caminho da glória e da felicidade; e se um grande descobrimento pertence ao primeiro que o assinalou,

a Rousseau que devemos esta saudável regeneração que tantas mudanças felizes operaram em nossos costumes, em nossos hábitos, em nossas leis, em nossos espíritos e em nossas atividades cotidianas.

Em seu primeiro olhar sobre o gênero humano, Rousseau percebeu de imediato a sujeição dos povos, sua prostração ante os cetros e as coroas, e ousou então pronunciar as palavras igualdade e liberdade.

Essas palavras ecoaram em todos os corações e os povos ergueram-se ao seu chamado.

Rousseau foi o primeiro a predizer a queda dos impérios e das monarquias; disse que a Europa havia envelhecido e que essas forças tão impressionantes tropeçariam e ruiriam como as antigas montanhas que o peso dos séculos fez afundar.

Político sublime, sempre sábio e benfeitor, estabeleceu a legislação segundo seus princípios de bondade. Afirmou que nas agitações violentas devemos ser prudentes conosco mesmos, que não podemos ser justos se não nos sentirmos humanos e que todo aquele que for mais severo do que a lei é um tirano.

O germe de seus imortais escritos encontra-se nesta máxima: A razão nos engana mais frequentemente do que a natureza. Fortalecido com esse princípio, combateu o preconceito, restabeleceu a natureza

5. Discurso pronunciado pelo presidente da Convenção Nacional, por ocasião do traslado da urna funerária de Jean-Jacques Rousseau ao Panteão, em 20 do vendemiário, ano III da República. 
perdida e, com seu apelo, a maternidade acorreu ao cumprimento de seus deveres mais naturais.

Por fim, como se Rousseau fosse o anjo da liberdade e todos os grilhões tivessem que cair diante dele, chegou inclusive a libertar a infância de suas disciplinas desnecessárias e fez com que a liberdade do homem fosse venerada desde o nascimento até a morte.

Cidadãos, o herói de tantas virtudes também seria seu mártir. Rousseau viveu na pobreza e seu exemplo nos ensina que não cabe à fortuna nem dar nem tirar a verdadeira grandeza.

Sua vida marcará época nos faustos da virtude e, hoje, estas honras, esta apoteose, este comparecimento de todo um povo, estas pompas fúnebres, tudo anuncia que a Convenção Nacional quer satisfazer ao mesmo tempo o filósofo da natureza, a aspiração dos franceses e o reconhecimento da humanidade.

\section{A ilha dos álamos trazidos da Itália}

Ao projeto de Ginguené e Lakanal sobre o traslado dos restos mortais de Rousseau ao Panteão, Barere quis acrescentar um encômio sentimental ao cenotáfio anterior de Jean-Jacques, a ilha dos Choupos construída pelo marquês de Girardin" ${ }^{1}$ :

Proponho uma ideia para servir de complemento ao belo projeto de decreto que vos acaba de ser apresentado. Castigaríeis a hospitaleira ilha dos Álamos por ter servido de abrigo aos restos de Jean-Jacques Rousseau durante quinze anos? Proponho à Convenção que não consinta em que fique totalmente desabitada, por assim dizer, e que ali ainda faça repousar a sombra de Jean-Jacques. Que sejam inscritos estes dizeres: "Nesta ilha, a sombra de Jean-Jacques Rousseau esperou a justiça nacional durante quinze anos". Entretanto, a proposta não vingou porque a Convenção julgou difícil decretar o paradeiro de uma "sombra", embora a Revolução evocasse com frequência "a sombra de Jean-Jacques.

Por outro lado, o próprio Robespierre achava melhor que Rousseau repousasse, graças à amizade, num "aprazível asilo da inocência e da natureza", e não no suspeito Panteão francês.

Houve também a proposta de "ermenonvillizar" ao invés de “panteonizar". Quer dizer, dispor as sepulturas em jardins de todo tipo, com monumentos erigidos por iniciativas seja por parte das famílias, das cidades ou do Estado, etc., sem que com isso existissem cemitérios fechados mais ilustres do que outros. ${ }^{2}$

Rousseau viveu suas cinco últimas semanas de vida em Ermenonville. Foi sepultado no parque ou jardim filosófico de seu anfitrião,

1 Procès-Verbaux du Comité d'Instruction Publique de la Convention Nationale, vol.V, 3IX-1794 a 20-I1I-1795, pp.40-51. Como já foi dito em nota anterior, normalmente traduzo peupliers por álamos, por ser este o nome de uso literário com significado mais abrangente para todas essas árvores. Mas, na verdade, parece que os álamos levados da Itália, assim como os atuais que ornam o sepulcro de Rousseau, eram choupos-pretos (populus nigra).

${ }^{2}$ ROBINET, Le Mouvement Religieux à Paris Pendant la Révolution, Paris, 1896, p. 537. 
o marquês de Gerardin, local onde se reuniram inúmeras personagens da França, da Europa e dos Estados Unidos da América do Norte. ${ }^{3}$

Arsenne Thiébaut narra a sua própria peregrinação à ilha dos Álamos com todos os ingredientes do culto a Jean-Jacques: seus encontros com os temas exaltados por Rousseau em A Nova Heloísa, Emílio e as Confissões durante o caminho de ida para Ermenonville: os sentimentos da maternidade e de ternura, as evocações da velhice, as grandezas da humanidade, os consolos da virtude, etc. ${ }^{4}$

Aproximava-me insensivelmente da ilha dos Álamos, onde se encontra a tumba de J.-J., e sentia como minha alma la sendo tomada por uma santo respeito; via diante de mim esse augusto santuário e sentia esse temor sadio, esse profundo recolhimento que envolve e penetra o espírito religioso quando nos aproximamos do templo da Divindade. Serenei e logo senti nascer em mim o sentimento tão natural que inspira uma boa mãe a seu filho quando lhe estende os braços e sorri... Avancei com rapidez... Um arrebatamento elevou-se dentro de mim e com toda liberdade as lágrimas brotaram de meus olhos "Terra feliz!" exclamei caindo de joelhos, "eu te saúdo; saúdote, ó tumba sagrada, venerável troféu da amizade, glória da virtude, consolo da humanidade!" A mais suave das imaginações se apoderou de mim; senti-me melancólico e sombrio, mil ideias confusas me rodeavam. Um sentimento que percebi melhor do que poderia expressar, uma devoção ardente, um enternecimento indizível, me dominavam. Chorei mais, e achei consolo... a alma virtuosa é imortal, voa até o seio da Divindade; a amizade lhe dedica um altar. Mas quão doloroso é ver-se separado do amigo fiel...

A fixação devota que Thiébaut e outros sentiram por Ermenonville os fez ver com maus olhos a saída dos restos de Rousseau da ilha dos Álamos e sua ida para o Panteão, no meio da cidade. A tumba de Rousseau já parecia inseparável da ilha projetada por Girardin. Ademais, o jardim filosófico que a rodeava era um conforto excepcional para os espíritos atraídos pela sensibilidade rousseauniana. Numa curiosa encruzilhada histórica, encontravam-se o Panteão republicano que profanava a basílica

${ }^{3}$ RIDEHALGH, A., "Preromantic attitudes and the birth of a legend: French pilgrimages to Ermenonville. 1778-1789", em Studies on Voltaire and the eighteenth century, 1982, pp. 231-252.

${ }^{4}$ THIÉBAUT, Arsenne, Voyage à l'isle des Peupliers, Paris, 1799, pp. 51 e 59. de Ste. Geneviève, a taumaturga, e o Panteão profanador do repouso bucólico de Jean-Jacques.

Com a queda de Robespierre, e sem que o "Incorruptível" lembrasse por que ele também queria Rousseau em Ermenonville, a devoção à ilha dos Álamos é redescoberta:

Rousseau espargiu consolo sobre a minha vida. À vista dos bosques de Ermenonville, sentimo-nos transportados para um mundo novo: uma melancolia suave, um entusiasmo divino libertam a alma de seus laços terrenos. Em 1791, um jovem, depois de passear vários dias nesses bosquetes, suicidou-se num banco mergulhado na relva, de onde se descortinava a ilha dos Álamos e a tumba de Jean-Jacques. Suas cinzas repousam modestamente sob sarças e aveleiras.

A ideia desse suicídio não é a única que aflige o homem sensível nos bosques de Ermenonville: foram mutilados os monumentos dedicados aos grandes homens. Uma mão bárbara fez desaparecer todas as inscrições inglesas... O cidadão Girardin, proprietário dos bosques de Ermenonville, não escapou às perseguições dirigidas contra as artes e a filosofia: ficou prisioneiro durante onze meses nessa morada, onde ele mesmo dera asilo a Jean-Jacques. Esse fato deve ficar registrado na história da tirania de Robespierre, que pretendia fazer o elogio de Rousseau perseguindo seus amigos e proscrevendo seus princípios 5 .

Joseph Michaud conclui com um poema de devoção ermenonvilliana onde tranquiliza os habitantes da aldeia dizendo-lhes que embora percam os restos mortais de Rousseau, que vão para o Panteão, conquistarão com isso maior honra e fama.

A história da ilha dos Álamos italianos é uma história mais longa e complexa do que, sem outra referência além da tumba de Rousseau, se poderia pensar. Para chegar à disposição feita por Girardin para abrigar os restos mortais do amigo, deve-se passar por um compêndio de filosofia e costumes morais do Iluminismo: os ideais fisiocratas, o paisagismo cenográfico dos motivos humanos neoclássicos, o jardim filosófico ou de retiro e meditação, o jardim inglês interpretado pelo naturalismo rousseaniano, incluindo casas rurais pitorescas e outras edificações

${ }^{5}$ La Décade Philosophique..., no 17, p.105 
destinadas aos trabalhos agrícolas; o museu "natural" da filosofia, ou a existência, num parque ajardinado, de inscrições e alegorias poéticas e filosóficas; o ideal contemplativo de referência rousseauniana, a rêverie; o ideal de moderação e conformidade ou jardim de Candide; a abertura universal de um refúgio particular... Tudo aponta para o romantismo nascente, mas sem a sua falta de contenção, e com uma materialização notadamente clássica: o parque filosófico de Girardin é cemitério, lugar de lazer, de contemplação ou rêverie, de observação botânica, de deleite agrícola, de convescote camponês e de turismo internacional.

Girardin redigiu seu projeto ${ }^{6}$ de união "do útil ao agradável” recordando que o primeiro dom da Divindade ao homem, a primitiva estância do homem feliz, foi um jardim.

A contemplação que deve ser exercida em tal lugar é assim definida por Girardin:

sem ser adusta nem selvagem, a situação Romântica deve ser tranquila e solitária, a fim de que a alma não sofra nenhuma distração e possa entregar-se por completo à doçura de um profundo sentimento.

Mas o lugar também é de trabalho rural. Girardin também discute questões econômicas e sociais da agricultura para obter resultados tanto estéticos como éticos. Diz que, para evitar a polarização do solo agrícola em latifúndios e minifúndios, o que produz muitos peões, poucos agricultores (colonos arrendatários ou parceiros) e grandes proprietários opostos ao livre-cambismo, devem ser dadas mais terras aos agricultores em regime de arrendamento. Dessa maneira, prossegue, haveria mais agricultores, que poderiam vender a preços mais competitivos, menos peões, que poderiam conseguir melhores remunerações, e proprietários obrigados a trabalhar como agricultores em lotes menores. Daí resultaria menor polarização social, comércio mais livre, experiência de trabalho mais em comum, salários mais altos para os trabalhadores temporários e uma paisagem mais harmoniosa devido à amplitude, à variedade e à distribuição das exportações.

${ }^{6}$ GÉRARDIN (Girardin), R.L., De la composition des paysages, ou des moyens d'embellir la nature autour des Habitations, en joignant l'agréable à l'utile, Genebra, 1777.
O parque filosófico de Girardin possuía um campo de cultivo, um prado de pastagem, uma casa camponesa, um moinho e alguns locais para operações rurais subsidiárias. Uma colina o prolongava através de um bosque até "o deserto", lugar onde afloravam as dunas arenosas do antigo fundo aquático de toda a região da "ilha de França". A composição edafológica, botânica e paisagística do jardim filosófico foi realizada por duzentos jardineiros ingleses sob a direção de um mestre de jardinagem escocês, trabalhando em Ermenonville durante dez anos.

\section{$\mathrm{Na}$ entrada do parque, Girardin colocou esta inscrição:}

O jardim, o estilo e o uso;

Pode ser inglês, francês ou chinês;

Mas a água, o bosque e o prado;

A natureza e a paisagem;

São de todos os países, de todos os tempos;

Por isso nesse lugar silvestre;

Todos os homens serão amigos;

E todas as línguas admitidas.

Quando Rousseau passeava pelo jardim deteve-se com alguma intenção desconhecida ante a coluna na qual Girardin mandara gravar os versos de Voltaire.

É preciso pensar, sem isto o homem se torna;

Apesar de sua alma, uma besta de carga;

É preciso amar, é o que nos valoriza;

Quem não ama nada não é digno de vida humana.

Rousseau, num ímpeto, superou essa dialética escrevendo na mesma coluna "À la rêverie". Girardin mandou apagar os versos de Voltaire e imortalizou a inscrição de Rousseau.

O monumento filosófico por excelência do parque é o templo inacabado da filosofia. Dedicado a Montaigne, "qui omnia dixit", ergue-se com seis colunas sobre uma base circular onde faltam mais colunas: "Quis hoc perficiet?" Cada uma dessas colunas em estilo toscano ostenta o nome 
de um pensador e um lema: Newton, Lucem; Descartes, Nil in rebus inane; Voltaire, Ridiculum; W. Penn, Humanitatem; Montesquieu, Justitiam; J.-J. Rousseau, Naturam.

Além de mais dois túmulos, o parque possui a famosa tumba de Rousseau. Girardin ordenou a formação de uma ilha no extremo do lago próximo ao prado da Arcádia. Ali plantou álamos vindos da Itália e, na frente da ilha que dava para a mansão do marquês, foi colocada a tumba de Rousseau. Esta obra foi de H. Robert com esculturas alegóricas de Le Sueur.

Numa pedra diante da ilha dos Álamos figurava esta inscrição:

Sob estes álamos, em singelo sepulcro

Rodeado de ondas plácidas

Estão os restos mortais de Jean-Jacques Rousseau,

Mas é nos corações sensíveis

Que esse homem da bondade e do sentimento,

Com sua alma, planta o eterno monumento.

Girardin mostrou entusiasmo pela Revolução e compareceu a várias reuniões dos jacobinos e cordeliers. Escreveu algumas reflexões inspiradas em Rousseau, mas logo ficou deprimido com o curso dos interesses humanos. Retirou-se para Ermenonville onde tampouco encontrou sossego, chegando a ser acusado de mau cidadão em 1793 e ficando preso em seu domicílio. A partir de então ocorreram várias pilhagens e vandalismos em seu parque. Uma vez livre, resolveu deixar Ermenonville e retirar-se para Vemouillet, onde morreu no primeiro dia da primavera de 1808.

Mas a grande originalidade de Rousseau, que se manifestará com diversas nuanças durante a Revolução Francesa, foi associar esses princípios de naturalidade, tão venerados por seus seguidores, aos direitos humanos entendidos tanto política, como moral e psicologicamente. Rousseau e a devoção rousseauniana da Revolução expandiram muitíssimo as consequências da ideologia dos direitos do homem, estendendo-os ao que já se pode considerar mais do que uma ideologia, a toda uma mentalidade. Ao mesmo tempo, essa mentalidade, a mentalidade revolucionária da civilização ocidental, acarretará um radicalismo tão natural que a linguagem da desigualdade e da opressão humana só poderá mudar a sua condição com o cultivo dos sentimentos e da imaginação. Por isso, o romantismo de linha rousseauniana não poderá nem quererá inspirar-se em outra coisa além da promessa ou da obtenção de uma maior liberdade efetiva para o homem. Por isso, também pensadores como Cabet continuarão a ver na libertação da naturalidade social dos princípios de sociabilidade defendidos por Rousseau - o objetivo ainda não realizado da Revolução Francesa, ${ }^{7}$ objetivo mais radical e universal do que a aplicação de uma melhor política de distribuição ou do que a extinção de uma classe social.

A Revolução Francesa foi capaz de implantar com naturalidade a ideia dos direitos do homem, transformando-a em mentalidade. De certo modo, essa realização tão importante não pode ser desligada de tudo o que contribuiu para fazer de Jean-Jacques Rousseau o melhor "santo" do Panteão. E fez isso quando o encontro da memória de Rousseau com os resíduos da Revolução para muitos só significava o encontro de duas sombras, o encontro que ainda pode ser percebido no vetusto e desfigurado Panteão ou no ajardinamento das ideias no parque de Ermenonville, onde a memória e o esquecimento observam o recém-chegado. Pois se a Revolução Francesa suscita em nós uma reflexão incessante, é porque ela com a sua força ainda não parou de nos observar.

${ }^{7}$ CABET, Étienne, "La République du Populaire", in 4ème Publication du Populaire, 1833, pp.14 e segs. 